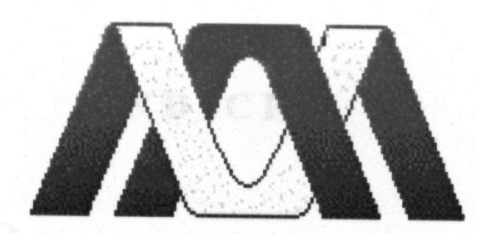

Casa abierta al tiempo

UNIVERSIDAD AUTÓNOMA METROPOLITANA

UNIDAD IZTAPALAPA

DIVISIÓN DE CIENCIAS SOCIALES Y HUMANIDADES

POSGRADO EN CIENCIAS ANTROPOLÓGICAS

Conflictos urbanos y gestión de espacios públicos en transición:

El caso de San Andrés Cholula, Puebla

Esperanza Concepción Martínez Vásquez

Tesina de Maestría en Ciencias Antropológicas

Directora: Dra. Ángela Giglia Ciotta

Asesores: Dr. Héctor Tejera Gaona

Dr. Emilio Roberto Duhau López

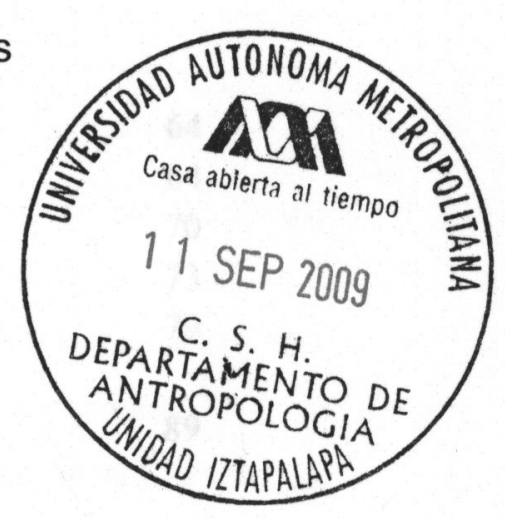




\section{Í N D I C E}

\section{INTRODUCCIÓN}

1. EL CASO DE ESTUDIO 6

$\begin{array}{lr}1.1 \text { Antecedentes históricos } & 6\end{array}$

1.2 Ubicación geográfica y datos generales 9

$\begin{array}{ll}1.3 \text { Situación actual } & 10\end{array}$

$\begin{array}{ll}1.4 \text { Conflictos urbanos, gentrificación y patrimonialización } & 15\end{array}$

2. TRANSFORMACIONES SOCIOESPACIALES 19

$\begin{array}{ll}2.1 \text { Nuevas Centralidades } & 20\end{array}$

2.2 El Centro histórico y la pirámide $\quad 21$

$\begin{array}{ll}2.3 \text { Zona de recreación, de residencia y servicios a estudiantes } & 27\end{array}$

$\begin{array}{ll}2.4 \text { Zona del periférico } & 37\end{array}$

2.5 Colonia Emiliano Zapata $\quad 39$

3. CONCEPTOS EXPLICATIVOS: Conflictos urbanos, gentrificación y

$\begin{array}{ll}\text { Patrimonialización } & 42\end{array}$

3.1 Conflictos urbanos $\quad 42$

3.1.1 Las relaciones sociales y el conflicto $\quad 42$

$\begin{array}{lll}3.1 .2 & \text { Conflictos sociales } & 43\end{array}$

3.1.3 Conflictos territorializados 45

$\begin{array}{ll}3.1 .4 & \text { Conflictos por el espacio }\end{array}$

$\begin{array}{ll}3.2 \text { Gentrificación } & 49\end{array}$

3.2.1 Gentrificación rururbana $\quad 54$

3.3 Patrimonialización $\quad 55$

3.3.1. Centro histórico $\quad 55$

3.3.2. Concepto 58

3.3.3. Acciones e intervención pública $\quad 62$

4. ACTORES INVOLUCRADOS

4.1 Autoridades locales $\quad 64$

$\begin{array}{ll}4.2 \text { Empresarios } & 70\end{array}$

$\begin{array}{lr}4.3 \text { Avecindados } & 73\end{array}$

$\begin{array}{ll}4.5 \text { Originarios } & 79\end{array}$

$\begin{array}{lr}\text { 4.1 CONCLUSIONES } & 89\end{array}$

$\begin{array}{ll}\text { BIBLIOGRAFÍA } & 95\end{array}$ 


\title{
CONFLICTOS URBANOS Y GESTIÓN DE ESPACIOS PÚBLICOS EN TRANSICIÓN: EL CASO DE SAN ANDRÉS CHOLULA, PUEBLA.
}

\author{
I N T R O D U C C I Ó N
}

Este trabajo está sustentado en el estudio y análisis de las transformaciones socioespaciales de un lugar que por efecto de la extensión de la metrópoli, experimenta procesos segregacionistas con efectos sociales que alteran su economía, política y organización comunitaria interna, contribuyendo de manera conjunta a situaciones de distanciamiento social y conflicto. Los intereses específicos se han enfocado en la conformación de nuevos espacios y actores insertos en la dinámica urbanizadora inducida desde el exterior por la sociedad global, con diferentes capacidades de apropiación de bienes materiales o culturales, discursos e intereses opuestos, interactuando en luchas grupales o individuales generadores de tensiones sociales y conflictos urbanos.

El lugar al que nos referimos en este estudio es la cabecera municipal de San Andrés Cholula, localizada en el valle de Puebla y las inmediaciones de la capital del estado, actualmente espacio de interacción integrado por una multiplicidad de actores provenientes de culturas distintas que intentan marcar territorialmente tradiciones y formas de vida específicas manifiestas en comportamientos diversos, tensiones y conflictos urbanos. Adentrarnos en la vida de un pueblo, de origen prehispánico, con una cultura de base territorial, esforzado desde hace muchos años en encontrar formas de relación con la diversidad cultural instalada por acciones modernizadoras en los años sesenta y más tarde reforzadas por la globalización, refleja una aparente subordinación a un cúmulo de acciones que inician con la extensión de la metrópoli hasta llegar a là compleja realidad actual que intenta globalizar el contexto rural que lo ha caracterizado. Es encontrarnos a la vez con una intensa relación social empeñada en mantener su diferencia cultural y una historia que podría considerarse exitosa en ese sentido.

Consideramos el estudio de los espacios y sus transformaciones, en la cabecera municipal, revelador del problema de las relaciones directas de los hombres con ellos, dotados de capacidad para contener y hacer(C. Jiménez, cit. en Authier y Bidou-Zachariasen, 2008:181), por lo que su conformación separada ${ }^{1}$ por clase social, gustos o estilos de vida, como los que se presentan apropiados por grupos de avecindados y los de los grupos comunitarios por la historia y el arraigo,

\footnotetext{
${ }^{1}$ Planeados con el objetivo de delimitar espacios físicamente distantes de los apropiados por los originarios.
} 
demuestra la forma en que se construye la relación de sus habitantes con él, la redefinición de relaciones entre grupos y sus interacciones a través de la puesta en marcha de proyectos, acciones y estrategias para su apropiación. Pero esta separación reproduce las desigualdades urbanas y es productora de desorganización comunitaria, por estimular de acuerdo con Wacquant, "prácticas de diferenciación y distanciamiento sociales internos que contribuyen a reducir la confianza interpersonal y socavar la solidaridad social local". (Wacquant, Loic, 2001:142) En este sentido, el trabajo de investigación permitirá el conocimiento de nuevas formas socioespaciales de exclusión y marginalidad, los procesos actuales que en este lugar las generan, sus dinámicas y dimensiones, formas en que han sido incluidos y los cambios socioterritoriales que los acompañan, en su articulación con la manifestación de conflictos urbanos, en contextos comunitarios forzados al encuentro con la diversidad cultural.

Nos hemos centrado en el estudio y análisis de los conflictos sociales y espaciales, en la cabecera municipal, como tensiones y contradicciones, por ser reveladores de proyectos y actores situados en diversas posiciones, con capacidades y recursos diferentes, inmersos en procesos de lucha y negociación para la defensa y obtención de bienes, que específicamente en este caso, resulta relevante por incluir y revelar las acciones de grupos de ascendencia indígena, "obligados a vivir en el ahora"(Lowenhaupt, cit. en Safa, 1998:128), con una estructura comunitaria, intereses en torno a la tradición e identidad, que desean preservar en interacción con la modernidad, defendiendo un territorio construido, sobre el cual ha transcurrido su vida social.

Nuestra hipótesis es formulada a partir de lo expresado por Patrice Melé, en el sentido de que los conflictos en su desarrollo son reveladores: “de apropiaciones, voluntades de apropiaciones; de oposiciones entre usos, las representaciones de la ciudad, de la naturaleza del ambiente y de lo que debe ser la acción pública urbano-ambiental(Melé, Patrice, 2001:17 )". Su conocimiento procesual permite considerar: los orígenes, conclusiones y discursos de legitimación que los constituyen en sus distintas fases, para comprender la construcción de la realidad actual en este proceso de adhesión forzada a la metrópoli. Los conflictos son parte de los procesos de transformación socio-territorial, que atraviesan este espacio, presentes en las dinámicas y formas de inserción de poblados como este, al interior de las grandes metrópolis, históricamente constituídos como territorios simbólico-significativos que responden a valores socialmente compartidos distintos a los urbanos. 
Procesos como el de gentrificación, reconocido como un fenómeno urbano, que recientemente ha sido visto como un camino provechoso de investigación por sus efectos en cuanto a la transformación de áreas y dislocamiento social de residentes, aparece en esta transformación socioespacial con características vinculadas a espacios de tipo rural como el de la cabecera municipal de San Andrés. La gentrificación en áreas rururbanas o periféricas se refiere a nuevas formas de elitización y ampliación del radio de poder y control social de los gentrificadores(Nates, Cruz, 2008:s/n), son procesos de territorialización diferentes a los instaurados por los originarios, que demuestran cómo se produce una recomposición territorial y social en la contemporaneidad rural. El mito de la vida en el campo, puede dar vuelta a vivir en el campo a través de lo rururbano pero ahora mediante el proceso de greentrificación(Phillips, Martin, 2008:s/n) ${ }^{2}$.

Como lugar apreciado por cualidades territoriales, culturales y sociales, también lo es por sus bienes patrimoniales, estimados por las autoridades locales que se unen a los intereses de los inversionistas: la pirámide prehispánica Tlachihualtépetl y el centro histórico, ambos lugares construídos social y culturalmente durante varios siglos, al interior de la actual cabecera municipal, como procesos históricos, sociales y culturales vividos por la población originaria. Este patrimonio, no puede ser considerado al margen de conflictos de clases y grupos sociales(Rosas, Mantecón, 2005:69), observables en el proceso de activación patrimonial que recientemente aparece como resultado de demandas de orden global y de identidad, que relegan a las de continuidad sociocultural de comunidades y grupos, para ubicarse como objeto cultural de consumo y nuevas formas de explotación y uso a través de la actividad turística y comercial. El proceso de patrimonialización es un proceso de transformación de bienes privados en bienes colectivos, que se seleccionan, consagran y exhiben cambiando su estado y usos. Considerando la ubicación y el origen de estos bienes que responden a una memoria, identidad y valores compartidos de una comunidad, el proceso de patrimonilización los convierte en formas simbólicas mercantilizadas con consecuencias como modificación de usos y prácticas, que conducen a disputas, conflictos y exclusión social.

De acuerdo con David Harvey, en las economías en general, y en la sociedad capitalista en particular, el interesante mando del dinero, tiempo y espacio forma un nexo substancial del poder social que no podemos enfrentar ni ignorar(Harvey, 1990:226), en ese sentido, el

\footnotetext{
${ }^{2}$ El concepto de "greentrificación" es construido por Martin Phillips con el vocablo "green" para expresar el renovado interés por las áreas verdes, cercanas a las urbanas, para insertar el proceso de geentrificación http://www.scitopics.com/Rural gentrification.html
} 
estudio de campo en la cabecera municipal de San Andrés, nos ha permitido evidenciar procesos de gentrificación y patrimonialización, como formas de acumulación de capital que a partir del nexo que menciona Harvey, reproducen las desigualdades sociales y traen un cambio en la composición social del lugar. Estos fenómenos serán analizados mediante el estudio de su impacto sobre la población originaria, como formas de imbricación de procesos y actores vinculados a diferentes ámbitos, que permiten la infiltración de poblaciones con alto poder adquisitivo o en ascendencia para la búsqueda de inversión de capitales, económicos, políticos y sociales, interactuando con los actores locales mayoritariamente obligados a enfrentar tales procesos, que mostrarán acciones territorializadas de acuerdo a las habilidades políticas, sociales y capacidad de recursos de cada grupo o actor. 


\section{EL CASO DE ESTUDIO}

En este capítulo consideramos de importancia para la comprensión actual de las transformaciones territoriales en la cabecera municipal de San Andrés Cholula, exponer inicialmente algunos datos del proceso histórico y relaciones de poder que lo acompañan y lo van conformando en una región urbana con una nueva escala de difusión de sus actividades. Enseguida hablaremos de la situación actual y características que lo definen como un espacio transformado por la urbanización y renovación de espacios patrimoniales, educativos, de esparcimiento y consumo, resultando atractivo para el asentamiento de avecindados, paseantes y empresarios interesados en la instalación de grandes proyectos y obtención de ganancias, que ocasionan procesos conflictivos por la intervención de diversos actores vinculados a la sociedad global, como la gentrificación y patrimonialización, que encuentran espacios para sus operaciones interactuando con instituciones locales, que son descritos y más adelante analizados en su articulación con las características y estructuración de espacios locales.

\subsection{Antecedentes históricos.-}

Acerca de la región de estudio se afirma que las ciudades de Puebla y Cholula, han mantenido una estrecha relación de intercambio simbólico y material desde el siglo XVI(Bonfil, 1973: 25), por lo que habría que considerarla como un campo de fuerzas desiguales de origen político, económico y social(Melé,1994: 255). De acuerdo con Bonfil Batalla, el proceso histórico no puede comprenderse si solo se concibe en términos locales, puesto que Cholula ha formado parte de un ámbito social más amplio, refiriéndonos con ello no únicamente a las relaciones que ha mantenido con un ámbito mayor, sino que "ha formado parte integrante de ese ámbito"(Ibid, 255).

La información que proporciona Bonfil sobre el proceso de estructuración de la región dentro de la sociedad global, se refiere a su relación con Puebla, que se estableció desde el inicio en forma dialéctica dando como resultado la erosión paulatina de la importancia de la región de Cholula y el incremento en la importancia de Puebla como nuevo centro del área(Bonfil, 1973:266). Este autor menciona factores como el decremento demográfico, la pérdida de poder político y la dependencia de Puebla, como indicadores del nuevo orden establecido a partir de la colonia.

Puebla se establece como ciudad colonizadora y Cholula como colonizada, lo cual ayuda a explicar las diferencias entre ambas relacionadas con los procesos de modernización para la primera y tradicionalismo para la segunda, que permanece como República de Indios con instituciones y 
modalidades de este tipo, conservando este orden hasta mediados del siglo XIX: un centro urbano indígena de una región indígena. En este sentido Bonfil Batalla, hace resaltar su excepcionalidad, consistente en el hecho de conservarse como una ciudad prehispánica que se mantiene indígena en sus aspectos esenciales(Ibid, 268), lo cual fue posible según este autor por el establecimiento de Puebla a una fecha tan temprana y en un sitio tan próximo.

Otro aspecto importante que resalta este autor, es el establecimiento del drenaje de recursos del campo a la ciudad, que en el caso de Cholula, desde su establecimiento como ciudad colonial, son transferidos para beneficiar a Puebla, dando lugar al empobrecimiento de algunos sectores productores si no necesariamente agrícola, de trasfondo agrario(Ibid, 268), surgiendo los grupos intermediarios y la conformación del "centro" equivalente a una dicotomía dentro de aquella ciudad. Resulta interesante comentar la tesis expuesta por este mismo autor en su obra, acerca de la relación y cercanía entre Puebla y Cholula, inversa a la del continuum folk-urbano de Redfield, como un proceso al que llama de des-urbanización(Ibid, 271) que según él impide un avance significativo de la urbanización, por mantenerse siempre esta región, con una economía dependiente de Puebla que funciona como centro capitalista, político y administrativo. Siendo tema de este estudio de esta investigación, los conflictos urbanos por las actuales transformaciones en el territorio de San Andrés Cholula, efecto de la extensión de la metrópoli, el interés por mencionar esta tesis radica en que habría que determinar cómo se han relacionado los factores urbanizadores y des-urbanizadores que Bonfil considera y la naturaleza de la relación entre las dos localidades y la sociedad global que las envuelve y determina la realidad actual.

Cabe mencionar como periodo detonador de cambios radicales en Cholula, los años sesenta y setenta, en el que se definen los actuales límites del municipio de Puebla, se construye la Universidad de las Américas(UDLA) en San Andrés Cholula, la vía rápida denominada Recta a Cholula y el gobierno del estado declara zona conurbada de la ciudad de Puebla a los municipios de San Pedro y San Andrés Cholula(Licona, 2007: 67). Con la construcción de la Universidad de las Américas en 1967, se impulsa la modificación urbana en la zona de Cholula y se implanta un eje de urbanización importante a lo largo de la vía rápida(Melé, 1994: 109) y comienzan los cambios socio económicos en San Andrés. Un informante refiere otro hecho además del anterior, como productor de cambios en las actividades productivas en San Andrés:

(...)el Proyecto de la Pirámide, para descubrir el tramo que está descubierto, porque antes no se veía nada de pirámide, todo era por túneles, el proyecto ese que le dieron a la universidad la parte esa que descubrieron se llevó algunos años, y a la gente si el campesino ganaba en ese entonces 60 pesos, y en ese proyecto al trabajador de fuera del campo, el que estaba rascando el registro de estudio, y todo 
eso, no sé cómo le.... el término real que le ponen ustedes, pa rascar, a ese le pagaban 105 a la semana y pues no menos de 500 personas trabajaban en ese proyecto y de alli ya había categorías, porque habia quien los mandaba, quien llevaba las bolsitas, quien ponia los nombres a las bolsitas, y quiensabe que le hacía a todo eso..... nosotros les nombramos acá "tepalcates" toda la cerámica destruída la guardaban en bolsitas, y allá en el museo regional a un lado, habia varias casas que ocuparon para que ... para ocupar mucha gente que fuera seleccionando y juntar las piezas. La verdad fue más, para mí, en mi concepto personal, fue más lo que se llevaron que lo que rescataron... Bueno rescataron mucho eh.. pero alli desde el trabajador de campo, el que estaba allí, robó hasta los más altos. Entonces este.... Allí se empezó a perder el campo, porque toda esta región, toda, toda, absorbió la mano de obra del campo... Luego, a la par, le digo se vino la UDLA, que esa en 3 años la hicieron, arrancó, y también traía el mismo número y más yo creo que hasta más trabajadores que el proyecto, ocupó gente de San Andrés y de otras regiones... (...), iban a traer a los trabajadores, pero venian ... así; de trabajadores para mano de obra. Pues si pues les convenía, si en su pueblo ganaban 50 pesos 60 , al campo,... aqui les daban 105, según la categoría que usaran, en la universidad pues a los albañiles, (...) les pagaban más $;. .$. pues...la gente fue abandonando el campo...(Hombre,65años, profesionista, originario)

Patrice Melé, en el estudio que hace de Puebla sobre urbanización y políticas urbanas en los noventa, explica que el impacto de la UDLA sobre la urbanización de la ciudad de Cholula, fue rápido gracias a las repercusiones financieras provocadas por la llegada de numerosos estudiantes norteamericanos en los primeros años de funcionamiento de la universidad. Alrededor de las instalaciones universitarias se desarrollaron numerosas discotecas y restaurantes, que constituyeron una zona de diversión, cuya clientela provenía desde ese entonces no solamente de la universidad, sino también de la ciudad de Puebla. Como efectos resultantes aparecieron las necesidades de alojamiento de una parte de la población estudiantil que impulsa tanto en San Andrés como en la ciudad de Cholula, la construcción de departamentos o casas individuales de alquiler. Las rentas eran más baratas que en la ciudad de Puebla y existía ya la facilidad de transporte posibilitada por la vía rápida, incrementando la intensidad de los enlaces por autobús entre las dos ciudades(Melé, 1994: 109).

Lo que interesa resaltar en este apartado, es la dependencia histórica que esta región ha mantenido con Puebla y el papel que esta ha ejercido como representante de la fuerza y de los intereses de las clases dominantes y de la sociedad global. Asimismo hacer notar que las relaciones de trabajo, comerciales, políticas y sociales, han sido asimétricas, completas y multifacéticas, manteniéndose Cholula subordinada a la metrópoli, en todas sus actividades(Ibid, 274), concluyendo con la exposición de los hechos más sobresalientes que de acuerdo a algunos investigadores en la zona y la visión de los informantes de la localidad, impactaron al sitio de nuestra investigación. 


\subsection{Ubicación geográfica y datos generales.-}

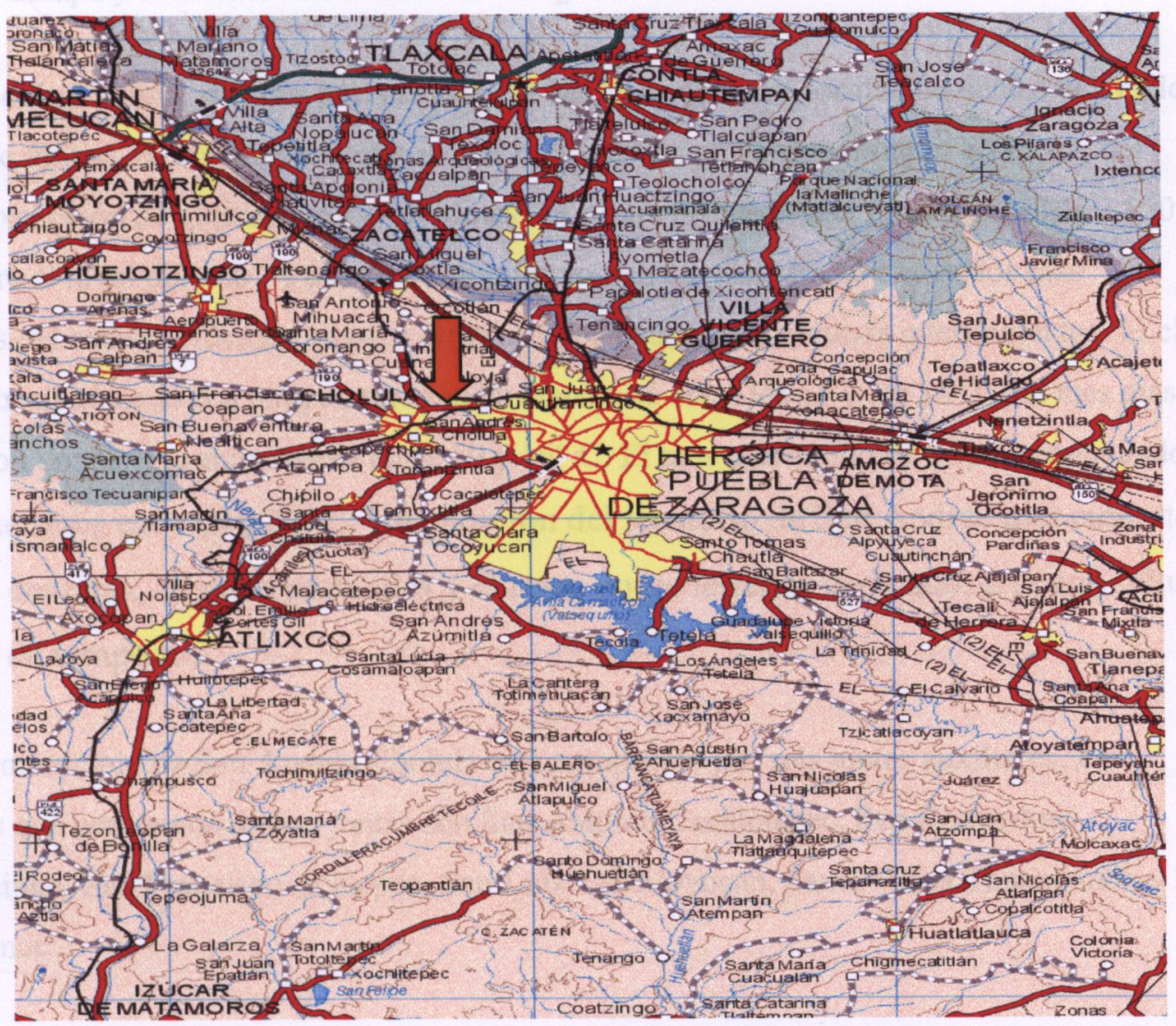

Fuente: http://www.worldmapfinder.com

El municipio de San Andrés Cholula pertenece actualmente a la zona metropolitana

Puebla. Por su cercanía al estado de Puebla su población ha crecido de forma importante en los últimos años. De acuerdo a los últimos censos realizados por el INEGI, el número de habitantes en el municipio pasó de 45, 872 en 1995 a 80,118 en el 2005 y en la cabecera municipal a 12,000 aproximadamente(INEGI, censo poblacional 2005). El grupo étnico principal es el mestizo y aproximadamente un $2 \%$ de la población actual habla alguna lengua indígena. En un $94 \%$ la población practica la religión católica, el resto practica el cristianismo protestante( $3 \%$ ) y el judaísmo(0.4\%).

Localizado en la región centro oriental del Estado de Puebla. La cabecera municipal del mismo nombre que el municipio, está localizada aproximadamente a $8 \mathrm{~km}$. De la capital del estado.

\footnotetext{
${ }^{3}$ Fuente: www.sanandrescholula.gob.mx
} 
Sus colindancias son al norte con San Pedro Cholula, al sur con Ocoyucan, al Poniente con San Gregorio Atzompa y al oriente con Puebla de Zaragoza. ${ }^{4}$

San Andrés Cholula, con una extensión de $61 \mathrm{~km}^{2}$, se encuentra localizado dentro del Valle de Puebla. Este último, es una planicie, por lo que no existe prácticamente ningún accidente del terreno, a excepción de algunas pequeñas lomas. La altura promedio del municipio es de 2.150 metros sobre el nivel del mar. A través del municipio corre el río Atoyac uno de los más importantes del estado. Además, existen otros arroyos pequeños y algunos intermintentes. El clima es templado subhúmedo. La temperatura media anual está entre los 18 y los $20^{\circ} \mathrm{C}$. El mes más frío es enero, con una temperatura media entre 10 y $16^{\circ} \mathrm{C}$. El mes más cálido es mayo, presentando una temperatura media entre 20 y $22^{\circ} \mathrm{C}$. Una porción del territorio de San Andrés está cubierta por bosque de encimas, algunos pastizales y el resto posee terrenos dedicados a la agricultura de riego y de temporal. ${ }^{5}$

El municipio de San Andrés Cholula está compuesto por seis juntas auxiliares. Las localidades que componen dichas juntas son San Antonio Cacalotepec, San Bernardino Tlaxcalancingo, San Francisco Acatepec, San Luis Tehuiloyocan, Santa María Tonantzintla y San Rafael Comac.

\section{Situación actual.-}

"Cholula" actualmente inserta dentro de la denominación cultural: "Las tres Cholulas", está integrada por los municipios de: San Pedro, Santa Isabel y San Andrés. La construcción de importantes vialidades que se convirtieron en ejes dě urbanización, detonaron grandes modificaciones socio-espaciales que impactaron a Cholula y los pueblos que la conforman. Actualmente, toda esta zona ha sido afectada y vive como efecto resultante de la urbanización acelerada de Puebla y su extensión hacia suelos agrícolas a los que transforma para su uso urbano, fuertes desequilibrios en la tenencia de la tierra a través de: la instalación de equipamiento en porciones colindantes de la mancha urbana(instalaciones de dependencias estatales o paraestatales); las redes técnicas(líneas de comunicación o de alta tensión, gasoductos, oleoductos); la invasión (ampliación de fraccionamientos privados) y la ocupación por parte del estado de tierras que este expropia legalmente.(Licona, 2007: 68).

\footnotetext{
${ }^{4}$ (Ibid.)

${ }^{5}$ (Ibid.)
} 
Otros autores estudiosos de la región han considerado que el proceso de metropolización de la ciudad de Puebla al incorporar en su dinámica a campesinos y pueblos colindantes como San Andrés, ha ocasionado un profundo cambio en la estructura urbana de Puebla, no solo en cuanto a su tamaño, sino en cuanto a su papel protagónico a escala regional(Licona, p. 39). Por ejemplo, Font encuentra que actualmente aparece una realidad territorial enormemente fragmentada y heterogénea, en la que se pueden observar espacios físicos de formas más o menos caóticas, en donde conviven estructuras tradicionales de ciudad con las nuevas modalidades del crecimiento que representan los procesos de dispersión territorial y de polarización, sobre los principales ejes y nudos(Ortíz y Andrade, p. 45).

Como resultado de los procesos arriba citados, la cabecera municipal de San Andrés Cholula, área de estudio, presenta en la actualidad una multiplicidad de procesos de interés para la indagación antropológica, en los que sobresale la interacción de grupos provenientes de culturas diversas quiénes atraídos por efecto de la urbanización y su centralidad patrimonial, lo convierten en un espacio en el que "las diferencias culturales, marcan territorialmente tradiciones y formas de vida específicas, que se reflejan en patrones de comportamiento diversos $y$, a veces, en tensiones $y$ conflictos interculturales" (Borja y Castells, 2002: 111), planteando como un reto esencial para esta sociedad, la gestión de dichos conflictos y la construcción de la convivencia en el respeto a la diferencia. Nuestra visión del caso de San Andrés, es la conformación de una realidad social dispar e injusta integrada por grupos social y económicamente desiguales a los que habría que ubicar para su estudio y análisis, de acuerdo con Canclini, en las relaciones de poder, que estructuran los usos del espacio y las representaciones sobre él(Canclini, en Signorelli, 1999: XII).

Interesados en el pensamiento y visión de la población oriunda, consideramos que los pueblos de origen indígena y gente de las comunidades como San Andrés Cholula, incluidas en esta dinámica de expansión urbana, no son una supervivencia, han resistido a la uniformidad y perseveran en la distinción cultural, como forma de encontrar sentido en medio de la modernidad a las prácticas sociales, actuando y mostrando, como lo expone Mariana Portal, "el ser pueblo en la ciudad" (Portal, 1997:44), a través de dos factores: el vínculo mítico-religioso con la tierra, como punto de partida de pertenencia a la comunidad y el parentesco, como uno de los ejes de organización colectiva. Ambos factores son atravesados por las creencias religiosas, que permiten la erección del espacio social, una delimitación y significación del territorio, la construcción de referencias de pertenencia y una forma de asegurar la unidad del grupo y su permanencia en el territorio, que según la autora no son determinados por elementos de la urbanización(Ibid, 45). Lo 
anterior puede ser vinculado a la observación de Canclini acerca de la exploración de los procesos de actualización que estas culturas han vivido, teniendo en cuenta que habría que perseverar en la consideración de su sobrevivencia investigando sus actuales vínculos translocales e intercambios que seguramente mantienen en la realidad actual(García C., 2007: 39).

En cuanto a la población avecindada, agrupamos a : familias de clase media y alta residentes, a las que transitan San Andrés y hacen uso de espacios públicos por asistir a alguna de las instituciones de educación básica ahí establecidas, paseantes metropolitanos, jóvenes universitarios residentes, en las categorías de yuppies y hippies, empresarios dueños de negocios o establecimientos y profesionistas o funcionarios que hacen uso y laboran en los centros financieros instalados en la localidad. En estos sub-grupos hay quienes atraviesan la zona y tienen encuentros en espacios como el área financiera, la zona universitaria, las nuevas áreas de consumo y recreación y quienes la han elegido para residir. Se trata de una población que muestra intereses individuales sobre su quehacer en el lugar, que se apropia de los espacios que habita y/o circula con bastante familiaridad, que construye sus expectativas en la creación y convivencia al interior de mundos de acuerdo a su estilo, considerando al exterior como un escenario inusual que modifican y enriquecen para la obtención de satisfactores diversos, despreocupada de considerar su contenido como una realidad social impregnada por relaciones densas, una historia e ideología propias.

Como espacio de adhesión a la metrópoli en proceso de urbanización recientemente intensificada, la cabecera municipal de San Andrés cuenta actualmente con atractivos históricos y patrimoniales importantes promovidos desde el gobierno local con fines turísticos, como el sitio de la pirámide prehispánica, el área urbana de traza cuadriculada, que incluye la "central". con el zócalo, las oficinas municipales, la parroquia y ocho templos barriales edificados desde la colonia, construcciones en su mayoría de estilos barroco, colonial y neo-clásico, que al igual que los de las Juntas auxiliares, datan de los siglos XVI al XVIII y están actualmente en trámite, para su reconocimiento como "centros históricos", mediante la publicación de información documental, un inventario de edificios y formulación de reglamentaciones, que desde el gobierno local intentan ser aplicadas para su resguardo.

Esta realidad urbana contrastante caracterizada por su diversidad, etnicidad y cosmopolitismo, se inserta y reconoce en lo que Ángela Giglia y Emilio Duhau, consideran y denominan espacio "ancestral": 
Un tipo de espacio sumamente complejo, por su diversidad cultural y urbanística, un espacio en donde conviven a poca distancia sectores sociales de procedencia social y cultura muy diversa, que pueden llegar a rozarse cotidianamente sin verdaderamente entrar en contacto $y$ conocerse. Más bien se evitan o se frecuentan solo en el marco de relaciones rígidamente configuradas como son las relaciones entre los "señores" y la servidumbre(Duhau y Giglia, 2008: 371)

Tratándose de realidades complejas que provocan encuentros y relaciones en muchas ocasiones forzados por la necesidad y mediados por prejuicios o experiencias previas con resultados no siempre positivos, se conforman ambientes en tensión o aparente tranquilidad. Lo anterior coincide con lo que estos autores mencionan como otra característica de estos espacios, en cuanto a que los motivos de conflicto están siempre latentes, situación suavizada por la delimitación espacial y al mismo tiempo por la mutua dependencia, manteniéndose cierto control mediante un ejercicio de tolerancia hacia el "otro"(Ibid, 377).

Estos mismos autores destacan varias características de los espacios ancestrales o pueblos incluídos en la metrópoli, que interesa destacar: como entidades provistas de la capacidad de autogobernarse y administrar su propia justicia y de recuperar su identidad mediante mecanismos como la religión, las festividades y la organización. Han demostrado también relaciones persistentes con el mundo exterior y una constante reconstitución de su memoria histórica y de la identidad local pese a los desalojos y despojos vividos, lo cual según Duhau y Giglia, habla de "comunidades locales sumamente dinámicas y vitales en cuanto a su capacidad cultural de dar sentido al devenir cambiante de la historia"(Ibid, 365). Estas capacidades son precisamente motivos de controversia en las nuevas relaciones que se establecen con los avecindados quienes califican de "atraso" y consideran como falta de respeto a sus derechos como nuevos residentes, muchas de las expresiones culturales y forma de organización comunitaria, basadas en la memoria y tradición, dos recursos importantes para la creación de identidades vecinales(Safa, 1998:121).

Encontramos que para el análisis del espacio de investigación, habría que considerar que los espacios "ancestrales", al ser atravesados por procesos de transformación y estar sometidos a múltiples presiones y contradicciones, se convierten simultáneamente en espacios "disputados", que en opinión de dichos autores, se debe a un conjunto de factores tanto intrínsecos como derivados de la dinámica metropolitana(Duhau y Giglia, 2008:239). Esta afirmación permite observar dos procesos en los últimos años en la comunidad analizada: grandes empresas constructoras han desarrollado zonas habitacionales y de servicios comerciales para sectores de clase alta y media promovidos por inmobiliarias impulsoras también de venta de terrenos, que ejercen presión sobre las autoridades locales y la tenencia de la tierra propiedad de los lugareños, 
por otra parte, el "centro" recientemente denominado "centro histórico", aún sin el reconocimiento oficial del INAH, ha sido remodelado y reorganizado por el gobierno local en cuanto a ejercicio y extensión de actividades comerciales y uso de suelo, que derivará en la próxima formulación de reglamentos de vivienda, construcción y vialidad, conformando un espacio que se distingue más bien, por la búsqueda de imagen urbana mediante apariencia uniforme en las construcciones recién pintadas, mejora, ordenamiento y limpieza de espacios públicos, sometido como queda expresado a la acción de políticas locales y externas que modifican e inciden en muchas de las prácticas sociales de los habitantes originarios.

Otra característica de San Andrés, es la de ser un lugar con una gran oferta de diversión cada vez más variada, para jóvenes metropolitanos que prefieren el ambiente calificado también de más permisivo que el citadino, con la consecuente alteración del ambiente "tranquilo" de la comunidad. En este sentido, los mismos autores encuentran que el conjunto de atractivos que este tipo de espacios ofrece, los convierte en víctimas de su éxito y objeto de intervenciones:

Asi de ser espacios cuy a centralidad se fue constituyendo a lo largo de decenios, en muchos casos se convierten de modo vertiginoso en lugares de paso de vialidades importantes o en metas de un público en busca de calidad urbana y de diversión más que en otros en la metrópoli, los habitantes perciben con angustia los cambios en su entorno inmediato que resultan de la intervención de diferentes actores económicos interesados en aprovechar su centralidad y calidad urbana convirtiéndolos precisamente en espacios disputados(Ibid, 252)

Cabe destacar como una intervención del tipo de actores interesados en aprovechar las cualidades urbanas de este lugar, la reciente creación de un espacio de consumo y diversión, que pretende clonarse y que destaca por su diseño "creativo" distanciado del espacio local implantado desde hace un año en el área central de San Andrés. Este espacio es llamado Container City que inspirado en modelos globalizados primermundistas se construye con estructuras de re-uso de containers, para integrar un pequeño centro comercial receptor de consumidores jóvenes estudiantes de la Universidad de las Américas y otros de procedencia metropolitana o extranjera que encuentran un ambiente internacional que gusta entre otras cosas por su contraste con el local.

Ante esta situación, consecuentemente el entorno se transforma simultáneamente en ambiente de inseguridad, como otra característica de este tipo de espacios, que los vecinos de la comunidad manifiestan mediante su desconfianza y temor por el futuro inmediato, la acción de las autoridades, vecinos, inversionistas, etc., que lo convierten asimismo en generador de posibles conflictos sociales. Se desconoce qué normas reguladoras se aplicarán, así como la organización de espacios públicos y privados regidos por un nuevo orden, en este sentido una originaria de San 
Andrés expresó lo siguiente ante una situación que le preocupa y que compara con la vivida en el pasado:

Nos da coraje con este presidente, porque vienen y construyen y ya....parece que tienen más preferencia que nosotros... porque el presidente no nos da a saber a nosotros de los "antros", solo de que ya se gastó en esto, en lotro, pero de antros no nos dice nada" ..... "yo les digo a mis hijos, antes no había luz pero era más seguro,....... ahora hay más luz pero está más inseguro" (Mujer, 35 años, ama de casa, originaria)

\subsection{Conflictos urbanos, gentrificación y patrimonialización}

El contexto social emergente se ha complejizado exigiendo la adquisición de nuevas destrezas y habilidades laborales, así comọ la realización de prácticas sociales distintas para insertarse en la dinámica urbanizadora. Las condiciones de alta plusvalía del terreno que lo ha convertido en una de las zonas residenciales más caras del área metropolitana, la construcción de nuevas vías de comunicación y desarrollos habitacionales de lujo, el encarecimiento en la vivienda y servicios y el mejoramiento o renovación de la arquitectura local, ha permitido el ingreso de clases sociales altas y medias con mayor poder adquisitivo y más alto nivel educativo que la originaria, acentuando las diferencias sociales; elementos que en conjunto nos hablan de la presencia de un proceso de gentrificación. Este proceso entendido como un desplazamiento o cambio en la composición de clase de un barrio o vecindario, es generado como una estrategia general de construcción en la ciudad que acompaña no solo al mercado residencial sino también a la recreación, al empleo y la economía cultural.

La gentrificación ha cambiado de ser un proceso marginal y fragmentado en el mercado de la vivienda a uno de larga escala, una política urbana sistemática y deliberada. Su extensión abarca a Latinoamérica y Asia en ciudades como Shangai y Beijing, por ejemplo, desplazando a cientos de miles de residentes de la clase trabajadora y pobre. Como una estrategia urbana generalizada, la gentrificación se entrelaza con el interés de los empresarios de la ciudad, desarrolladores y terratenientes, incorpora a empleados y a instituciones culturales y educativas que dependen de una fuerza laboral de profesionistas y se vincula ahora a la demanda creciente de bienes rurales que deben consumir los citadinos del sector medio y superior. Representando un avance en cuanto a su radio y estrategias de acción, este fenómeno introduce nuevas formas de inserción, dinámicas y dimensiones de alto impacto en la economía local.

El paisaje rural, con sus grandes extensiones verdes, en las inmediaciones de las grandes metrópolis, que remiten a valores simbólicos como la idea de "vivir mejor" o "vivir de otra 
manera", ha cobrado un nuevo interés en muchos países como una respuesta a la crisis de la ciudad(Nates, Cruz, 2008:10). De esta manera, grandes extensiones han sido "vaciadas" y adquiridas para su ocupación por clases medias y altas, que llegan a instalarse dando una vuelta al campo, ahora mediante el proceso de gentrificación rural, que ocasiona importantes transformaciones socioterritoriales a las cuales deben adaptarse las poblaciones rurales. El proceso de gentrificación hace referencia a la forma en que se produce una recomposición social y territorial de la contemporaneidad tanto urbana como rural.

Otra situación que aparece en este escenario de interacción de grupos locales y ajenos, actuando como inversionistas y autoridades locales, se encuentra vinculada a la reciente valoración, de parte del gobierno local, por resaltar la zona de monumentos históricos ubicados en la cabecera municipal: la pirámide, la traza reticular y monumentos religiosos del "centro" y juntas auxiliares bajo su jurisdicción, promoviendo una estrategia de imagen urbana(Melé, 2006:121) y su promoción en medios, enlazadas a otras de la iniciativa privada, que buscan la instalación de proyectos que fomenten y atraigan al turismo.

Patrice Melé opina que "el moderno culto a los monumentos y su protección, así como el surgimiento de un discurso sobre el patrimonio, constituyen una tendencia internacional de la acción pública urbana"(Melé, 1998:13) El posible cambio de estatuto de edificaciones del siglo XVI, XVII y XVIII en San Andrés, de bienes privados a colectivos y su reconocimiento como patrimoniales, aunado a la presión del mercado inmobiliario y aumento de servicios financieros en la zona, son elementos que se presentan en procesos de patrimonialización que Laplante define como "proceso de transformación del estatuto de un bien privado en público(Melé, 2006:86)" y que dependen de acciones comunes entre los poderes locales y las instancias federales, apoyado por acciones públicas como en este caso, el remozamiento del centro histórico en el marco de una acción de protección a sus monumentos que instale a poblaciones citadinas y atraiga al turismo.

Desde los poderes locales y distintos grupos que ahí residen, intervienen o desean intervenir, se habla de reorganización, reglamentación y consecuentes prohibiciones a corto plazo, pero escasas acciones de interés por la vida cotidiana en proceso de transformación de los habitantes del pueblo, quienes serán considerados "guardianes locales de un valor patrimonial que pertenece a la humanidad(Seppanen, Maaría, 2003:18)" . La preservación de tradiciones e identidades es un discurso que en realidad gira alrededor del patrimonio cultural, considerado como promotor de desarrollo económico y en menor grado, social. Las acciones del gobierno local han optado por formular su propia política de protección al patrimonio histórico existente, como ha 
sucedido en otras entidades del país, comenzando con la publicación de un inventario de monumentos y reglamentos independientemente de su aprobación ante el INAH, para su nuevo uso, justificándose en su preocupación de protegerlo al visualizarlo como una futura actividad económica en la región.

Lo que nos interesa recalcar como consecuencia del proceso de patrimonialización y específicamente relacionado con el caso de estudio, es el hecho de que en su activación se encuentran insertos conflictos por las diferentes visiones y actores externos que lo conforman, verdaderamente alejadas de la percepción de los actores locales, para quienes se trata de un patrimonio vivido con significados vinculados a su historia e identidad. Por otra parte, la patrimonialización entendida como un proceso que tiene efectos sobre las prácticas sociales de uso de espacios comunitarios, se convierte en detonador de conflictos y encuentra en este lugar un nicho para su reproducción como forma de insertarse en el marco de políticas internacionales que justifiquen los efectos mencionados.

Considerando que ambos procesos: gentrificación y patrimonialización, tienen efectos estigmatizantes sobre la población originaria, estimulan prácticas de diferenciación internas, contribuyen al distanciamiento social, a la reducción de confianza interpersonal y socavan la solidaridad social local(Wacquant,2001:142), los conflictos sociales que se generan, presentan a una comunidad en adaptación y conflicto latente por la intrusión de fuerzas externas e implantación de proyectos y políticas públicas, que en algunos casos desconoce y con las que deberá lidiar mediante acciones sobre el control de la tierra, uso de espacios y monumentos patrimoniales, que justifica el convertirse en objeto de estudio y análisis de esta tesis

El actual potencial económico del municipio de San Andrés y los intereses de la sociedad global que lo ubica como nicho de reproducción de nuevos modelos socio-económicos, son factores que influyen en la conformación de las transformaciones más importantes del entorno, que se complejiza si lo relacionamos con los antecedentes históricos y socio-culturales de la zona y con una imbricación de actores sociales ligados a los negocios, las instituciones educativas, las políticas de venta y alquiler de vivienda frente a la comunidad que actúa como una cultura territorializada, resultante de su histórica apropiación simbólico-expresiva de un espacio ancestral(Giménez,2000:27). 
La delimitación física de espacios, ha sido considerada como una fragmentación de la cabecera municipal, mediante la aparición de centralidades o sub-centros de interés para los nuevos pobladores: el zócalo y la pirámide o patrimonial, actualmente renovadas, que giran hacia el turismo, la de recreación, la financiera, la de franquicias y plazas comerciales cercanas a los desarrollos habitacionales ubicados a lo largo de las nuevas vías de comunicación para clases acomodadas, avecindados y turistas. Todos ellos nos interesan especialmente como espacios de distinción productores de exclusión social y por sus cambios relacionados con la acumulación de capital social de actores que luchan por su apropiación y dominio, "en especial adueñándose(material o simbólicamente) de los bienes escasos(públicos o privados) que se distribuyen en él(Bourdieu,1993:122) y que depende del capital poseído". El siguiente capítulo de esta investigación estará integrado con la descripción de la delimitación espacial y nuevas centralidades en San Andrés, para su posterior valoración y análisis. 


\section{TRANSFORMACIONES SOCIOESPACIALES}

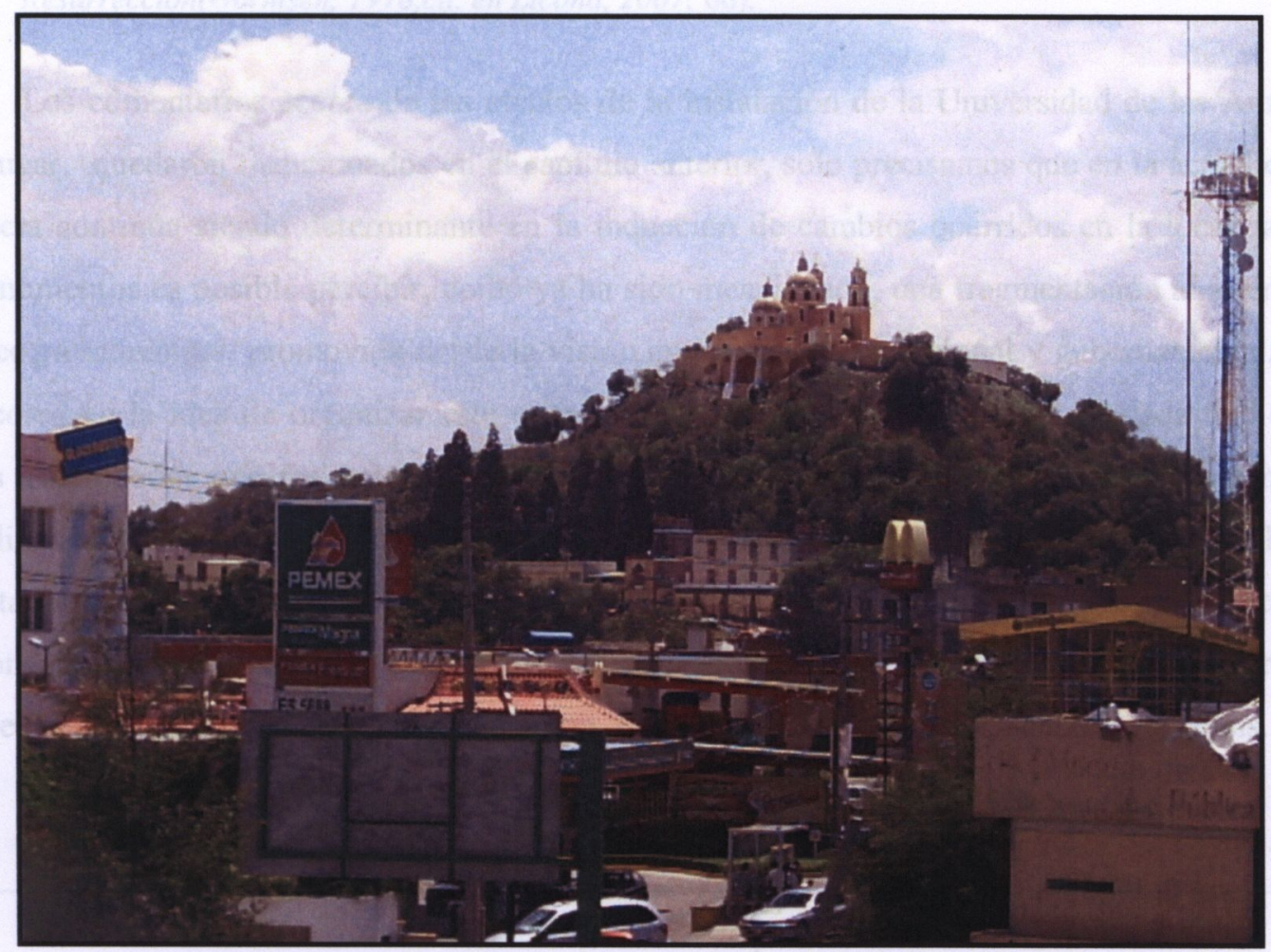

Pirámide Tlachihualtépetl y Cerrito de los Remedios, Año 2009

Como quedó expuesto en el capítulo anterior, a partir de los años sesenta, surgen modificaciones importantes en el municipio y su cabecera, que permanecen en la memoria de los originarios quienes las consideran momentos cruciales de cambios en su vida comunitaria. Entre ellos recuerdan con precisión la construcción de la recta Puebla Cholula, de la Universidad de las Américas y los trabajos del INAH para el descubrimiento de la pirámide. En este capítulo precisamos brevemente los factores del contexto global inductores de dichas modificaciones registrados por estudiosos de la región y enseguida describimos el contexto actual, en el espacio de la cabecera municipal, área de observación durante la reciente estancia de trabajo de campo que permitió un acercamiento a la compleja problemática en San Andrés.

Es oportuno citar textualmente lo que Gormsen en 1978, mencionado por E. Licona, expone en su estudio sobre "La zonificación socio-económica de la ciudad de Puebla. Cambios por efecto de la metropolización":

En 1962 se da la apertura de la autopista Puebla-México; en ese mismo año Pemex crea una planta en San Martín Texmelucan, en 1966 es inaugurada la VW y en 1967, HYLSA, todo esto con un fuerte impacto en los flujos de mano de obra y las oportunidades de empleo creados en la 
región(Gormsen, 1978:8). De esta manera la ciudad incrementa su número de habitantes y el espacio fisico se amplía, hasta incluir ciertos pueblos y ciudades aledañas como Cholula y la Resurrección(Gormsen, 1978, cit. en Licona, 2007: 66).

Los comentarios acerca de los efectos de la instalación de la Universidad de las Américas en el lugar, quedaron mencionados en el capítulo anterior, solo precisamos que en la actualidad su presencia continúa siendo determinante en la inducción de cambios ocurridos en la localidad. En estos momentos es posible percibir, como ya ha sido mencionado, una fragmentación al interior de la cabecera municipal, promovida desde la visión empresarial, institucional y gubernamental, entre otras cosas en la idea de organizar este espacio para atender las necesidades de cada uno de los grupos avecindados que residen y atraviesan el lugar. En este sentido se han conformado nuevas centralidades y zonas de desarrollo urbano en San Andrés que para fines de análisis las hemos delimitado, aunque no se rigen por criterios estrictos, es decir, en todas ellas podemos encontrar relaciones y presencia de los "otros" que no corresponderían a nuestra delimitación, pero que durante una breve estancia de trabajo de campo, facilitaron su observación, estudio y análisis.

2.1. Nuevas Centralidades:

\begin{tabular}{|c|l|l|}
\hline \multicolumn{2}{|c|}{ Centralidad } & \multicolumn{1}{c|}{ Usuarios } \\
\hline 1 & Centro histórico y pirámide & $\begin{array}{l}\text { Originarios/autoridades(funcionarios, } \\
\text { burócratas)/avecindados/turistas }\end{array}$ \\
\hline 2 & $\begin{array}{l}\text { Zona de recreación(Container City), } \\
\text { residencial y de servicios a estudiantes y y } \\
\text { avecindados }\end{array}$ & $\begin{array}{l}\text { Avecindados/turistas/empresarios/origin } \\
\text { arios/Instituciones educativas }\end{array}$ \\
\hline 3 & $\begin{array}{l}\text { Zona financiera y de franquicias } \\
4\end{array}$ & $\begin{array}{l}\text { Zona residencial del Periférico } \\
\text { Avecindados/funcionarios/turistas }\end{array}$ \\
\hline 5 & Colonia Emiliano Zapata & $\begin{array}{l}\text { Avecindados(estudiantes } \\
\text { residentes)/instituciones educativas } \\
\text { Avecindados(residentes)/Instituciones } \\
\text { educativas }\end{array}$ \\
\hline
\end{tabular}




\subsection{El Centro Histórico y la pirámide}

El centro histórico ${ }^{6}$.-

Esta "centralidad" la adquiere por su traza ${ }^{7}$ y edificios históricos cuya construcción data en algunos de ellos, del siglo XVI como el caso de la Parroquia, el Palacio de Gobierno del siglo XVII, los portales, el zócalo y los ocho templos del siglo XVIII, distribuidos en cada uno de los barrios conformados durante la colonia, retomando elementos prehispánicos del "calpulli", alrededor de los cuales gira la vida social, política, económica y religiosa de las familias originarias que se distinguen por permanecer en un alto porcentaje, en la residencia barrial organizada desde la época prehispánica, mediante lazos de parentesco. Es un área con límites "indefinidos", que solo se reconocen entre los originarios en términos de referencias a sitios específicos en ese perímetro y abarca aproximadamente treinta cuadras alrededor del zócalo. Esta centralidad cargada de profundos valores simbólicos de gran significado cultural para la comunidad, incluye la presencia de autoridades políticas, civiles y religiosas, sitios conmemorativos, espacios sagrados, otros públicos y privados y los sitios de residencia definidos por lazos de consanguinidad, alrededor de los cuales construyen su pertenencia y símbolos identitarios en los que históricamente se reconocen.

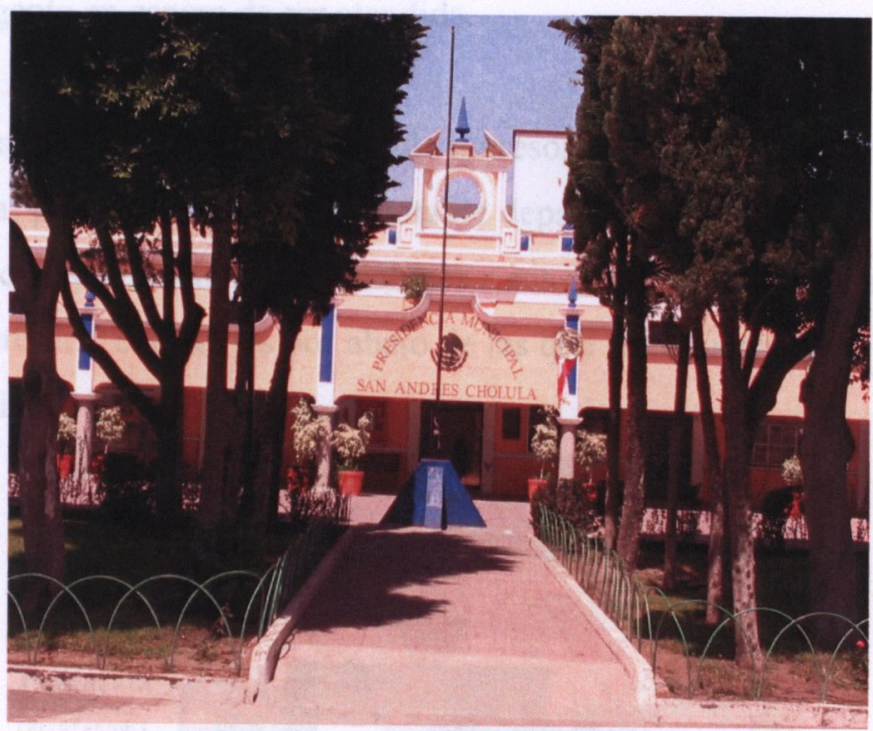

Zócalo y Presidencia Municipal

\footnotetext{
${ }^{6}$ Lo llamamos "centro histórico" de la misma forma en que las autoridades locales se refieren a esta área, en trámite de su certificación ante el INAH y organismos internacionales.

${ }^{7}$ La traza es "emparrillado" como continuación del existente en San Pedro Cholula.
} 

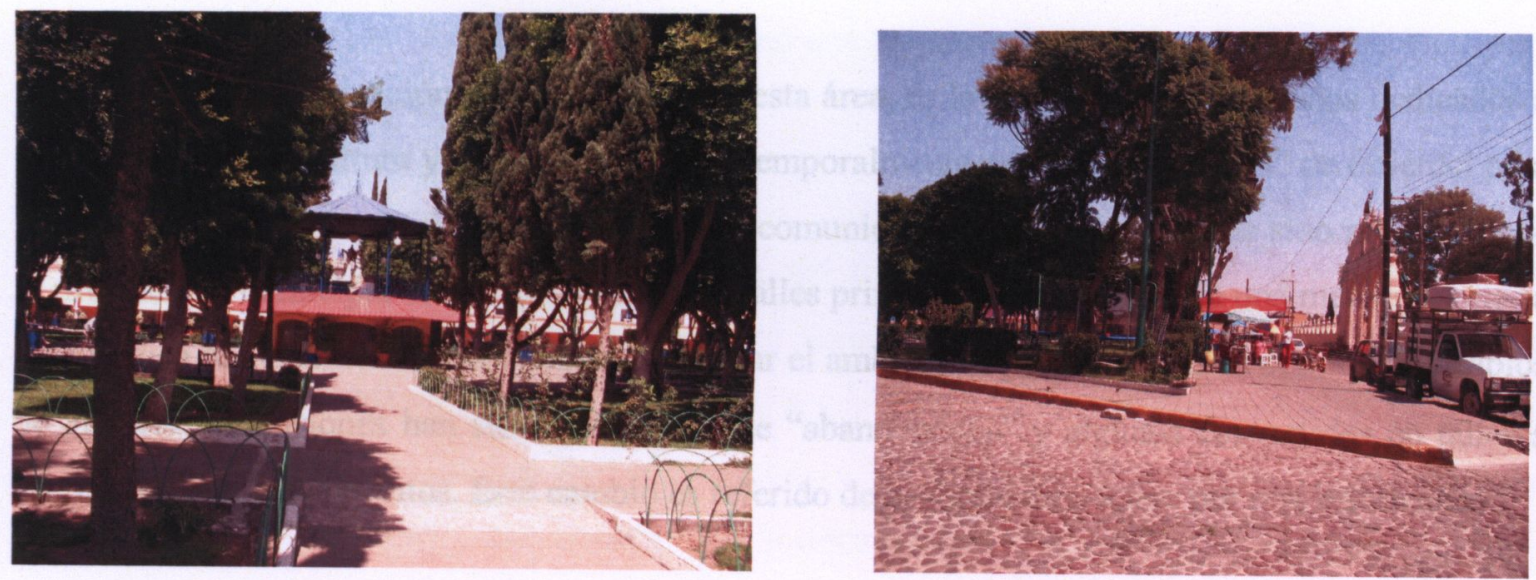

Centro Histórico San Andrés

Las calles que rodean al zócalo fueron recientemente adoquinadas y substituyen a las empedradas, señalando en todas ellas vialidades para bicicletas, medio común de transporte. Varios lotes de más de 500 metros, que anteriormente eran de uso agrícola o ganadero, a escasos metros del zócalo, se han convertido en estacionamientos públicos para autos y son atendidos por vecinos de San Andrés, que también son propietarios, interesados en hacer producir sus terrenos a partir del reciente incremento en el movimiento en las oficinas municipales para la realización de trámites diversos como pago de impuestos, licencias para construcción, etc., que ha ocasionado un aumento en el flujo vehicular y gente en espera de ser atendida.

Como una forma adicional de búsqueda de ingresos de parte de las familias sanandreseñas localizadas en esta área, prolifera la oferta de renta de departamentos y casas, que autoconstruyen con el mínimo de servicios o realizando adaptaciones a sus propiedades y cediendo o compartiendo parte de su terreno a este fin, con rentas por abajo de las que se encuentran en la zona cercana a la universidad y al periférico.

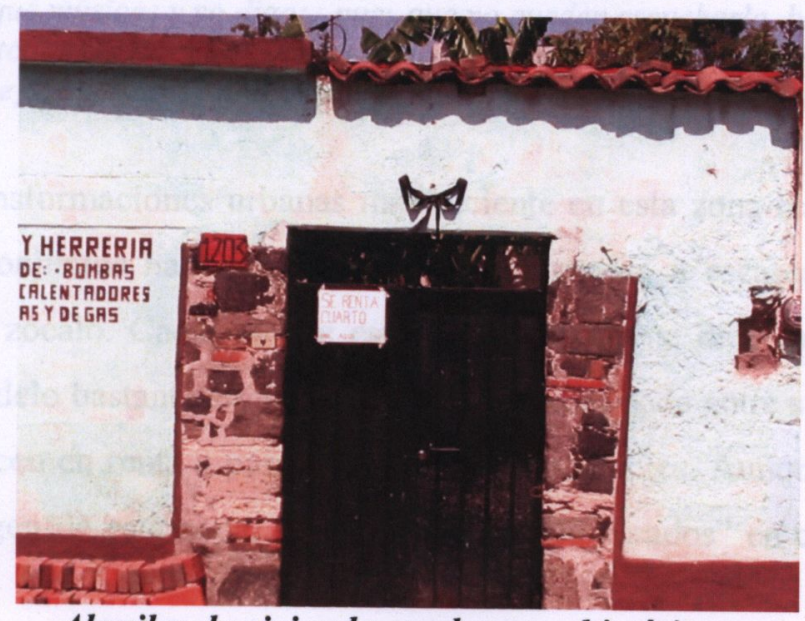

\footnotetext{
Alquiler de vivienda en el centro histórico
} 
Otra transformación reciente dentro de esta área, es la desaparición de terrenos dedicados a la ganadería o agricultura y de otros utilizados temporalmente como "asoleaderos" de estiércol para convertirlo en fertilizante, práctica común en la comunidad que recientemente ha sido prohibida por la presidencia municipal en y a lo largo de las calles principales como parte de una medida sanitaria y ecológica recientemente promovida para sanear el ambiente en esa sección, en donde dos establos de grandes dimensiones han sido aparentemente "abandonados" y algunos convertidos en talleres mecánicos o lavado de autos. Este cambio es referido de la siguiente manera por una informante:

El anterior(presidente municipal), dijo que iba a multar a los tiraderos de estiércol porque eso era pura contaminación, pero vimos que no pasó nada, todo siguió igual....Ahora ya pasa más días el camión de la basura y ya no hay tiraderos de estiércol....pero nos dicen que nos van a cobrar lo del camión, nos van a pasar un recibo.... En la escuela ponen a reciclar a los niños, cartón, plástico.... Y ya les hablan los maestros de la contaminación ... que los vasos desechables dilatan no se cuanto para reciclarse y aquí con tanta fiesta que ahora sirven todo en vaso desechable, todo es desechable.... Antes les digo a mis hijos tan bonito que te servian el refresco en vasos de vidrio........) (Mujer de 37 años, ama de casa, originaria)

Se trata del área más "tranquila" y ordenada de la cabecera municipal, con uso residencial regulado. En este perímetro no hay antros ${ }^{8}$, aunque se vienen introduciendo en la modalidad de "botaneros" y el número de establecimientos comerciales es reducido. Los espacios de diversión son de tipo familiar: jardines de fiestas y el balneario de San Juan o "Puerto Escondido", al que tradicionalmente acude gente de la comunidad y visitantes convirtiéndose los fines de semana en lugares ruidosos y con bastante movimiento vehicular que molesta a los avecindados quiénes expresan:

¿Cómo me siento? Bien, pero lo que no me gustó y que no me imaginaba era la contaminación del ruido. Porque aqui todo el año los cuetes, a veces es durante toda la noche; $y$ son unos cuetones que no te dejan dormir, o bien, te despiertan pero sobre saltado, es horrible $i j$.

Después, ya ves que estamos enfrente del balneario, bueno, pues toda la mañana ponen la música a todo volumen y qué música; y yo digo: ¿ pues que no pueden escucharla bajito?, ¿ Porqué tiene que ser tan alto? ;... todos los fines de semana se llena y la gente mete vasos y bolsas de plástico en la malla de alambre;(Mujer de 57 años, ama de casa y profesionista, avecindada)

Una de las transformaciones urbanas más reciente en esta zona residencial, consiste en la construcción de tres conjuntos habitacionales para clase media, a escasos metros del área de la pirámide y cuatro del zócalo. Cada uno de estos conjuntos tiene diez casas en una sola planta, construidos con un modelo bastante similar y extensión aproximada entre sesenta y ochenta metros cuadrados, que se ofrecen en renta a parejas jóvenes y estudiantes. Aunque podría decirse que su estilo no altera la imagen de esta zona, resultan ser "conglomerados" en comparación con su uso

\footnotetext{
${ }^{8}$ Nota: recientemente han permitido la instalación de un "botanero" a dos cuadras del zócalo
} 
anterior por una familia "extensa" de la localidad que no superaba a doce miembros habitando un lote de estas mismas proporciones.

Como comentamos en la presentación del caso, uno de los proyectos inmediatos del gobierno local que traerá más cambios en esta zona consiste el reconocimiento como "centro histórico" ante el INAH, trámite iniciado simultáneamente en forma independiente y de manera conjunta con el gobierno de San Pedro, contratando los servicios profesionales de una empresa quien armará un expediente que incluya toda la documentación oficial existente de los edificios religiosos y sitios patrimoniables en ambos municipios(incluyendo juntas auxiliares), elaborará un inventario de monumentos históricos, una publicación y la reglamentación para su uso, en el interés de resguardar y mantener el patrimonio de la zona en las mejores condiciones para producir y promover proyectos de turismo cultural. Otro proyecto consiste en la creación de un corredor turístico que una al sitio de la pirámide con el zócalo, promovido con intenciones comerciales. Estas acciones son visualizadas como actividades que en un futuro generen ingresos a la región e inserten a los originarios todavía dependientes de los recursos provenientes de la agricultura y la ganadería, que indudablemente modificará el uso de espacios en esta sección de la cabecera municipal.

La pirámide: Tlachihualtépetl

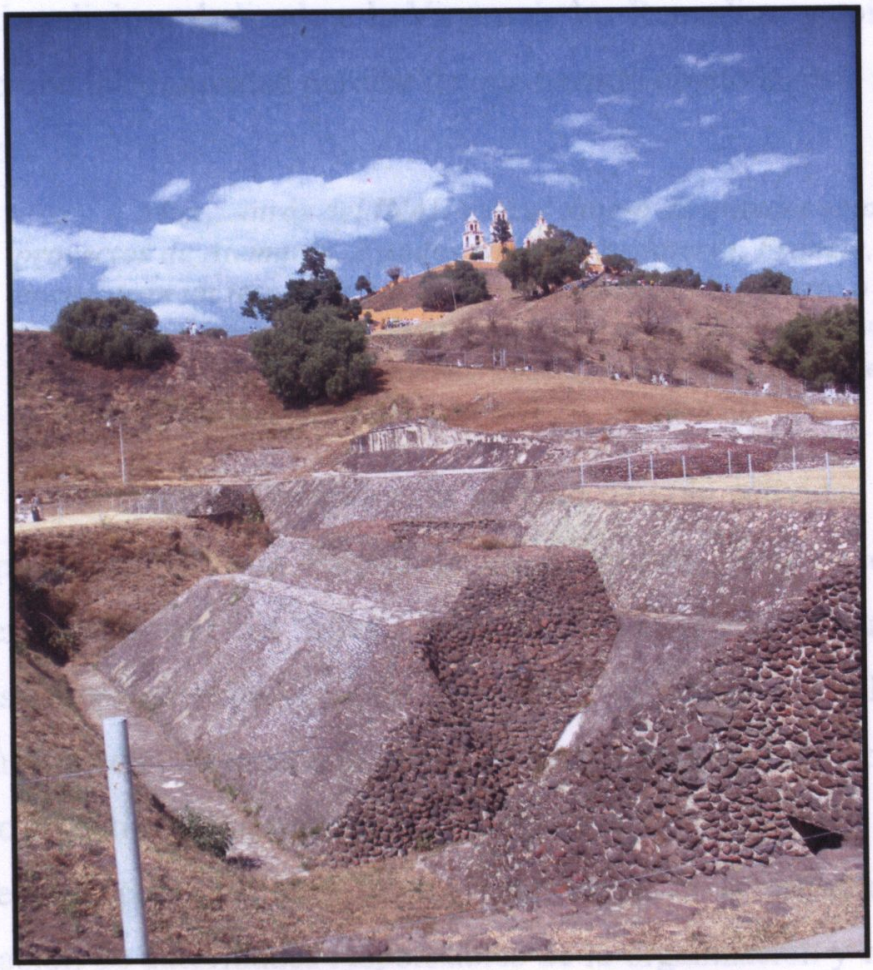


Por tratarse de una zona patrimonial federal decretada por el INAH, a partir del 6 de diciembre de 1993, existen restricciones en cuanto al tipo de construcciones de uso residencial que son rigurosamente observadas. Sin embargo, ocupando una parte del área central de los terrenos que circundan a la pirámide, anteriormente de uso agrícola, se construyeron una cancha de futbol, otra de beisbol y recientemente un complejo deportivo instalado sobre una extensa área del terreno anteriormente abierto, con pista de pasto sintético y espacios adicionales para la práctica de deportes, graderío en ambos lados y a todo lo largo, cercada con una malla que recientemente fue inaugurada y que inicia con acceso libre o restringido de acuerdo a la actividad programada, lo cual es identificado como un cambio en el uso de suelo y de espacio público a privado. Por sus características, este nuevo espacio es usado principalmente por avecindados y visitantes

La pirámide se encuentra en la zona límite entre los municipios de San Pedro y San Andrés y desde tiempos históricos ha sido zona de conflicto por reclamar ambos su pertenencia. La comunidad cuenta historias y narra mitos acerca de sus orígenes o recuerdos de las últimas excavaciones realizadas por el INAH en los años sesenta, que reflejan la desconfianza hacia esta institución; muchas más derivadas de su representación para la gente de la comunidad, como santuario religioso dedicado a la Virgen de los Remedios, y coincidiendo en comunicar el acto de despojo que la comunidad percibe de que ha sido objeto en esta zona y que materializa en narrativas locales:

Mire, atrás del INAH está el dinero de grandes empresas transnacionales, a través de proyectos de Alemania, Estados Unidos, Inglaterra, Francia, España.... Entonces cuando encuentran un tesoro, ¿de a cómo nos llevamos?..... ¿Cierto o no?.... Si aqui se encontró una serpiente con una cabeza de oro, que ni la pluma la podía levantar....Aqui en la zona arqueológica, no lo levantó la pluma.. y muchas cosas, ¿ quien es el culpable?.... es nuestro sistema el propio gobierno(Hombre, de 73 años, ganadero, originario)

Como santuario religioso, es un sitio de gran actividad por la realización de festividades y "acompañamientos" a la Virgen de los Remedios, patrona de la región, quien actualmente es representada por sus tres "hijas", llamadas "las moleritas" quienes bajan a visitar a cada uno de los pueblos comprometidos con esta gran fiesta, de acuerdo al calendario ritual y festivo al cual se vinculan las de los santos patronos de cada barrio en cada comunidad, representando un espacio sagrado en actividad permanente. La llegada de la "molerita" a cada comunidad, parroquia o barrio es celebrada con una feria popular que activa a la estructura barrial que corresponda, en la designación de autoridades responsables de la organización y cobro de cuotas(cooperaciones) a las 
familias del barrio que deben sufragar los altos costos de su realización, en las que no participan los avecindados.

Es también sitio de actividades culturales como la del equinoccio de primavera que se realiza desde hace varios años, para un público diferente al comunitario, originando cambios recientes en su realización. Recientemente este festejo, se organizó como: "Primer Festival del Equinoccio de la Primavera", con la participación de varias instituciones instaladas en los municipios de San Andrés y San Pedro, que de común acuerdo dividieron el área para la organización conjunta de esta actividad. El municipio de San Andrés, mediante la vinculación con la UDLA, el INAOE, institutos de ciencias y dependencias oficiales de cultura, celebró en forma más destacada y con un horario más extenso, además del equinoccio de la primavera, el año de la astronomía, organizando actividades relacionadas con esta ciencia, otras esotéricas, culturales y de entretenimiento en una programación que cubrió todo el día.

De parte del gobierno actual, se pretende impulsar un proyecto para crear un andador turístico que comunique a esta zona con el zócalo, convirtiéndolo probablemente en un espacio comercial con venta y exposición de artesanías, etc.. También existe la intención de organizar una vida festiva más intensa alrededor de este símbolo histórico para vincular patrimonio y turismo cultural, lo cual es aprovechado mediante proyectos empresariales instalados en las cercanías al sitio que pretenden entre otras cosas crear ambientes internacionales que el turista disfrute por su originalidad mediante la fusión local-global, que también se expresa en la creación de bebidas y comidas en estos negocios, convirtiéndose en agentes de cambios sociales en la comunidad.

Para concluir este apartado, retomamos la afirmación de Melé en cuanto a que: "el centro histórico ha quedado englobado en la ciudad moderna"(Melé: 102), que es el caso de las ciudades más grandes de este país y claramente apreciable en este, reforzado por el desarrollo urbano de los últimos años y por sus atractivos como espacio ancestral y disputado, convirtiéndose en un nicho que alberga una amplia gama de proyectos productivos de gran envergadura para su transformación actual y que revela el intenso juego de poder que lo caracteriza en este momento como espacio así caracterizado. 


\subsection{Zona de recreación, de residencia y servicios a estudiantes}

\section{Ciudad Contenedor(“Container City").-}

A dos calles de la pirámide y seis después del zócalo, en dirección hacia la vía denominada "Recta Puebla-Cholula", aparece una de las más recientes "centralidades" comerciales, interrumpiendo abruptamente con el ambiente colonial dejado seis calles atrás: histórico, tradicional e identitario, para pasar a otro vanguardista, de carácter privado, tomado de un modelo internacional ajeno y distante de la cultura local, existente en ciudades mundiales como Nueva York, Inglaterra y Holanda, dirigido a turistas, paseantes, jóvenes estudiantes y avecindados de la zona. El sitio es conocido como "Container City" y funciona en la actualidad como espacio recreativo y comercial.

Container City $^{9}$ es un proyecto implantado desde hace un año, formando parte de la conocida zona de diversión, antros y gastronomía, desarrollada desde los setentas en la calle 14 oriente, alrededor de la Universidad de las Américas. Una de las características de este lugar es su cercanía con la pirámide, que se observa, al igual que los volcanes, de manera destacada desde sus instalaciones formando parte del escenario natural y atractivo "particular" de este sitio.

Ocupando un terreno de aproximadamente $1000 \mathrm{~m} 2$, sobre la 12 oriente, este centro comercial urbano retoma un concepto "vanguardista" importado de países primermundistas. La creatividad de empresarios de origen libanés, retoma modelos de New York, Inglatera y Holanda, para ofrecer en sus inicios, containers de re-uso, con fines habitacionales para jóvenes estudiantes. Este proyecto fue creado a la vez como espacio creativo, vinculado al tema de la ecología, dirigido

\footnotetext{
${ }^{9}$ Antecedentes de este Proyecto: Fuente: Senior Blog, que muestra información del periódico La Nación: Se trata de una empresa inglesa que fue la pionera de esta idea. El objetivo inicial: montar casas y oficinas en donde antes hubo "mercaderías". Erick Reynolds, tuvo la idea de reciclar "boxes" viejos. La empresa se llamó Urban Space Management, en Londres, creando el proyecto en dos fases: container City I y Container City II, en el 2001 y 2002 respectivamente.

Características: En espacios reducidos de $30 \mathrm{~m} 2$ aproximadamente, se crea un espacio habitacional con todos los servicios, en un diseño creativo e innovador dirigido a jóvenes, artistas y diseñadores y estudiantes, que aguardan en lista de espera, para ocupar estos espacios. Ha sido un modelo reproducido en toda Inglaterra y Holanda. Las zonas en que se ubican han sido especialmente terrenos que no son rentables para laonstrucción. Se crea un complejo en bloques, que incluyan oficinas, café, supermercado y área deportiva, con servicios de intranet. Tienen una vida útil de 20 años, después de los cuales se pueden levantar y llevar a otro lado.

Se menciona una situación que explique y justifique la creación de este proyecto: China envía 7 millones de containers al año a EUA, regresando a dicho país únicamente 250, por lo que ahora con esta idea, se aprovechan al reciclarse y venderse como "quick houses"

En España: El alcalde de Mataró, España los adopta por calificarlo de un proyecto sostenible, rápido y

económico, con un costo a la mitad de lo normal que puede levantarse en 15 días.

Fuente: Periódico La Vanguardia

Ambas fuentes aparecen en el buscador de Google
} 
gente joven, artistas y diseñadores, que apreciaran la originalidad del concepto, ofreciendo talleres de diseño gráfico, en un intento de implantar una "ciudad creativa" y que más tarde, por su improductividad, deciden convertir en centro comercial que conserve espacios creativos y además agregue los productivos: restaurantes, bares, cafeterías y boutiques de lujo:

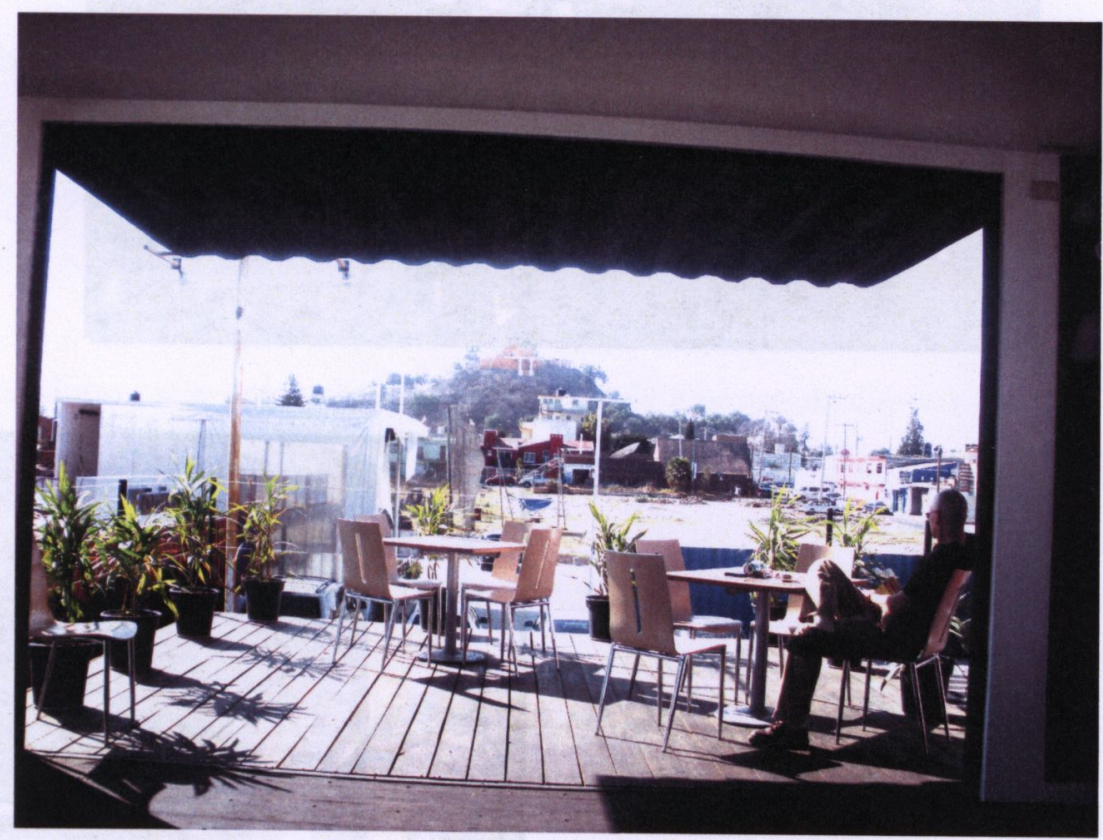

Container City y Pirámide Tlachihualtépetl

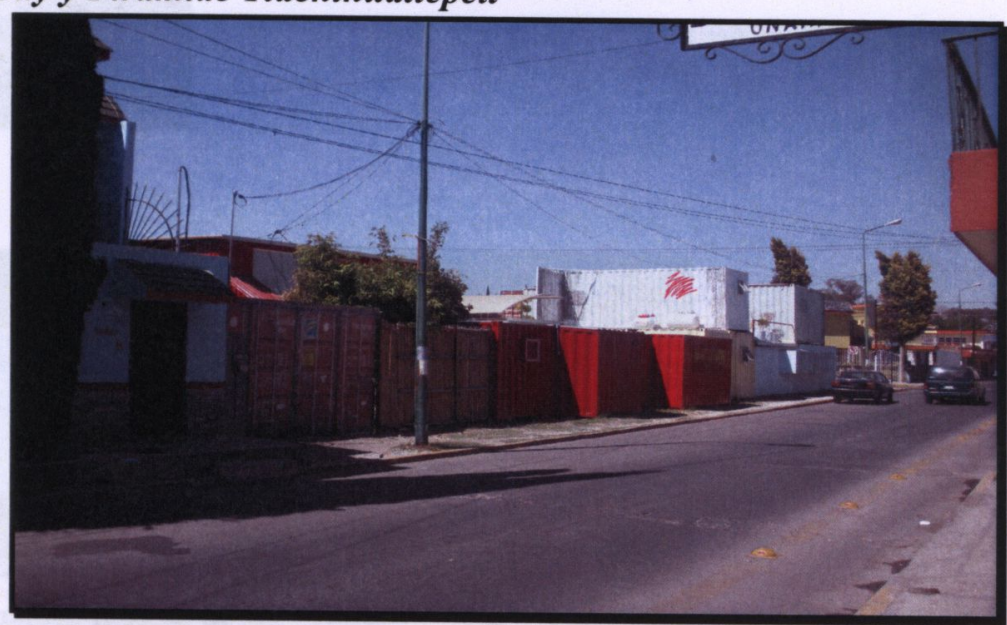

Container City 

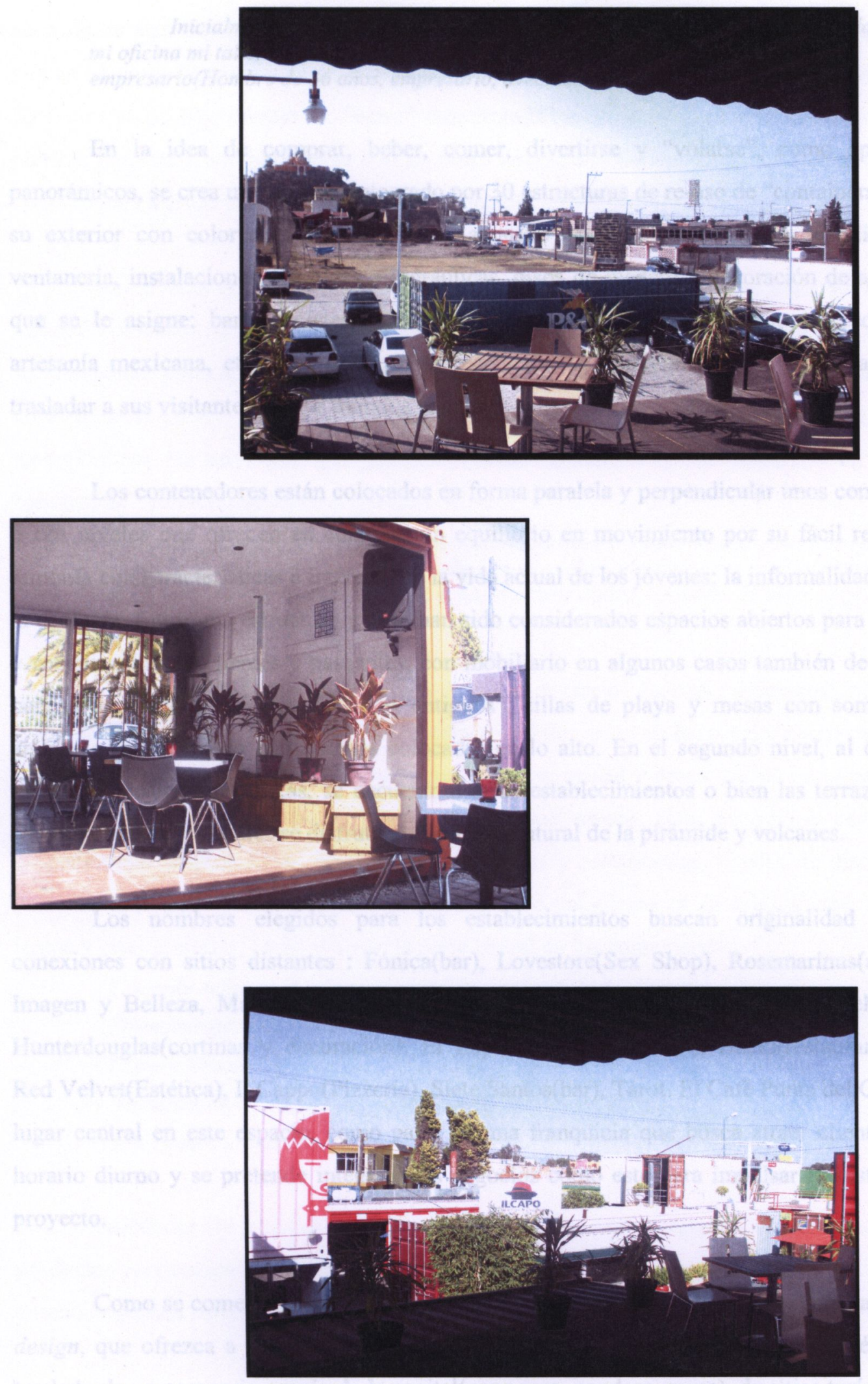

Container City(interiores) 
Inicialmente habia talleres aqui abajo, era una "ciudad creativa", yo todavía tengo aqui en mi oficina mi taller de diseño gráfico, pero no.... ahora buscamos que sea creativo y

empresario(Hombre de 36 años, empresario, avecindado)

En la idea de comprar, beber, comer, divertirse y "volarse", como aparece en los panorámicos, se crea un conjunto integrado por 30 estructuras de re-uso de "containers" pintados en su exterior con colores "explosivos"(rojo, amarillo canario, verde limón) acondicionados con ventanería, instalaciones eléctricas e hidráulicas, pisos de madera y decoración de acuerdo al uso que se le asigne: bares, cafetería, restaurant, boutiques de ropa, calzado, accesorios, música, artesanía mexicana, etc., sobresaliendo la recreación de ambientes interiores en la intención de trasladar a sus visitantes a otros mundos lejanos.

Los contenedores están colocados en forma paralela y perpendicular unos con otros, en uno o dos niveles que ofrecen en conjunto un equilibrio en movimiento por su fácil reubicación, en armonía con características e intereses de la vida actual de los jóvenes: la informalidad, movilidad y la ecología. Entre una estructura y otra, han sido considerados espacios abiertos para la circulación y socialización de clientes y paseantes, con mobiliario en algunos casos también de re-uso, como bancas de madera, asientos de cine "antiguos", sillas de playa y mesas con sombrillas en un ambiente musicalizado con bocinas colocadas en lo alto. En el segundo nivel, al que se accede mediante escaleras metálicas, se encuentran otros establecimientos o bien las terrazas de bares y cafeterías desde las cuales se disfruta el escenario natural de la pirámide y volcanes.

Los nombres elegidos para los establecimientos buscan originalidad y establecen conexiones con sitios distantes : Fónica(bar), Lovestore(Sex Shop), Rosemarinus(aromaterapia), Imagen y Belleza, Materia Design, Red Velvet, Bianco: fashion room, Psichodelya: Boutique, Hunterdouglas(cortinas y decoración), El Zapata M.R.(restaurant), Hackl(restaurant), Taxi(bar), Red Velvet(Estética), Il Cappo(Pizzería), Siete Santos(bar), Tarot. El Café Punta del Cielo ocupa un lugar central en este espacio, como parte de una franquicia que busca atraer clientela segura en horario diurno y se pretende integrar más negocios como este para impulsar la sustentabilidad el proyecto.

Como se comentó anteriormente, se intenta la trasposición de un ambiente "ajeno", fashion design, que ofrezca a sus clientes el atractivo de sentirse parte del mismo. También pareciera el traslado de un escenario propio de la capital(zona rosa, condesa, roma), de sitios turísticos de moda o de aeropuertos internacionales. Los establecimientos son escaparates para la difusión de 
actividades tipo new age, algunas esotéricas, cursos de yoga Jivamukti en San Andrés, y otras culturales como: exposiciones de arte y talleres de creación literaria. Los domingos se ofrece en el área central un espectáculo de "salsa" interpretada por bailarines reconocidos que atraiga a un público familiar. También cuenta con un muro de grandes dimensiones que representa un espacio creativo para artistas plásticos que deseen realizar alguna obra.

Se comenta que los propietarios de estos negocios, son en muchos casos los mismos de los "antros" ubicados en la calle principal de la zona de diversión(14 oriente), en su mayoría inversionistas poblanos(corporativo), políticos o juniors de la capital y de ex_alumnos de la UDLA(Ex-AUDLA) que deciden permanecer en San Andrés integrándose al grupo de inversionistas en un lugar que promete buenas ganancias y los mantiene en un ambiente "alivianado" y divertido, sobre el que comentan:

Estamos en una "ciudad" que se está renovando constantemente, unos(estudiantes) vienen y se van y luego llegan otros, además algunos se quedan, efectivamente, si encuentran oportunidades como ésta y siempre va a ser así, ..... y hay bastante dinero;(Hombre, 25 años, empresario, avecindado)

En cuanto a los visitantes, acuden desde empresarios, turistas extranjeros, señoras en grupo que van de compras o a tomar el café mientras los hijos están en la escuela, parejas y familias que desayunan o simplemente pasean y observan con curiosidad y detenimiento este espacio novedoso que descubren y les asombra. Este ambiente que ofrece: arte, accesorios de uso personal, aromaterapia, belleza, cafés, lectura de tarot, bares y restaurantes, tiendas de diseño y galerías, incluye como parte de su decoración exterior que complementa su originalidad, fragmentos de textos y citas literarias, escritos sobre la parte lateral de los containers:

" $Y$ cuando despertó el dinosaurio todavía estaba ahi", A. Monteroso.

"Normalmente no rezo, pero si estás ahi, ;sálvame Superman $i$ i, Homero Simpson

"I have a Dream.....", Martin Luther King

"Why drink and drive, if you can smoke and fly?

"Si te vuelas, no manejes"

Alrededor de este sitio comienzan a instalarse otros negocios tipo lounge-bar, venta de productos para cocina internacional, espacios de creación artística o literaria que van integrándose y extendiendo esta zona de entretenimiento para avecindados y paseantes. 


\section{La 14 Oriente:}

Como lo describe Melé, esta zona empezó a ser urbanizada desde los setentas, un poco después de la apertura de la Universidad de las Américas, aunque sin presentar la urbanización actual, y más bien integrada al resto del pueblo. Los vecinos recuerdan que las primeras inversiones en discotheques que se instalan en el país eligieron San Andrés enseguida de Acapulco (lugar pionero en esta modalidad), para la instalación de "El Bazar" y el "Tyffany"s", otra de dos plantas y base redonda, que resultó ser la "novedad" del momento por mantenerse a la delantera de Puebla. El resto de negocios, fueron pequeños y de muy poca inversión, ya que los desórdenes y conflictos por la venta del alcohol, siempre ocasionaban cierres y reaperturas temporales, manteniéndose durante muchos sin rebasar un número mayor a quince y con los mismos dueños. Desde sus inicios fueron antros frecuentados por los primeros extranjeros estudiantes de la UDLA, en los que se encontraban, como la gente recuerda, varios ex-combatientes de Viet Nam y gente adinerada de la metrópoli, conformándose un espacio novedoso de diversión con un ambiente alternativo, informal y menos restrictivo que en la capital.

Anteriormente los que daban desorden pues eran los gringos, ... que el desorden era de que ya cuetes, principalmente las chavas ya a la una o dos de la mañana, empezaban a hacer entre ellas su show, pero nosotros re divertidos no? Pero hasta ahi, y pues habia marihuana y alcohol, pero eso siempre ha habido, pero no como ahora que anfetaminas, coca, pericazos, en fin ya de todo eso........)(Hombre de 65 años, empresario y profesionista, originario)

En las inmediaciones de la UDLA, actualmente se han ubicado alrededor de 120 negocios comerciales propiedad de avecindados y cuarenta bares, en un tramo no mayor a las siete cuadras, adquiriendo una vida intensa en el horario nocturno, con una oferta gastronómica y de diversión musical que agrada a un público cada vez más amplio de avecindados: noche de jazz, noche techno, noche de DJ's, de salsa, etc., promociones al dos por uno, a partir del medio día en los restaurantes, etc., y otras modalidades como botaneros y cervecerías, que funcionan desde el medio día. Estos espacios son decorados de acuerdo a su estilo que puede ser desde: lounge bar, discos que se reservan el derecho de admisión, restaurantes-bares mediterráneos, grandes palapas que evocan el "estar en la playa", marisquerías, botaneros y suschi-ito, se observa por lo general algunas peculiaridades como el gusto alternativo y menos formal que el citadino. A lo anterior se debe incluir la renta de un creciente número de lotes para su uso como estacionamientos de los antros y restaurantes establecidos. 


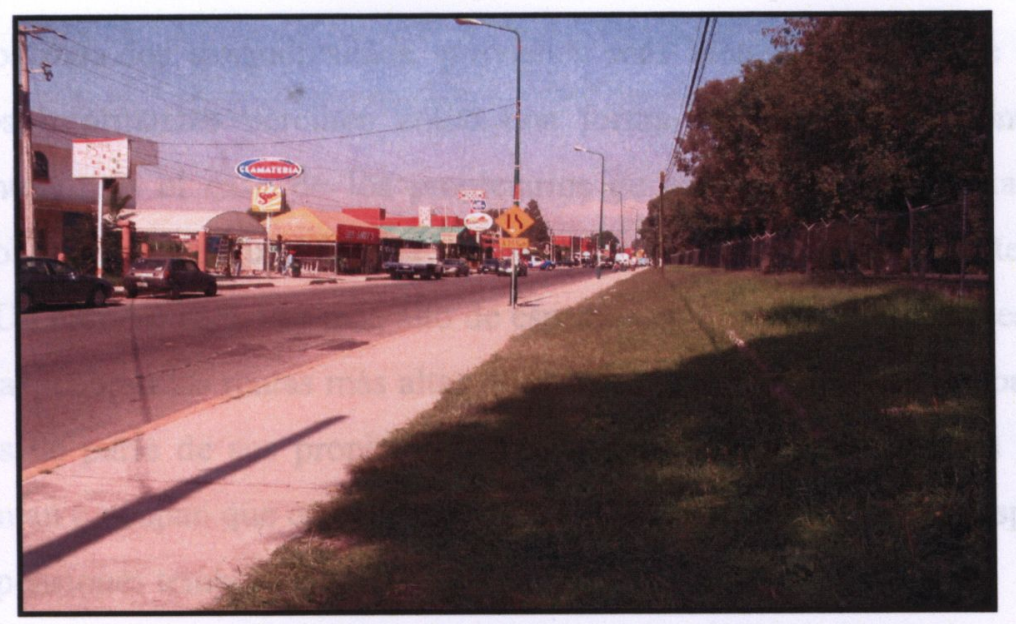

\section{4 oriente y UDLA}

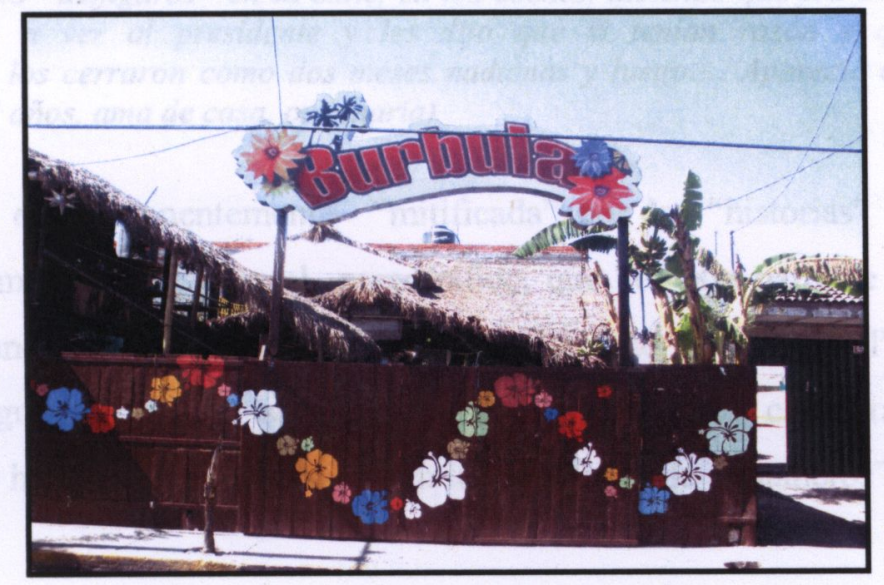

14 oriente

Esta calle se presenta como una vialidad de las más amplias y urbanizadas, con cuatro carriles, topes y semáforos en forma lateral a la universidad. La prolongación de esta calle en sentido hacia Puebla, cambia su nombre a "Camino Real a Cholula" y comunica a San Andrés con las zonas residenciales y comerciales de lujo, conocidas como Zavaleta y Angelópolis pertenecientes a esta municipalidad pero insertas en la metrópoli. A lo largo de esta vía se establecen más instituciones privadas de educación básica y superior como la universidad Madero, el Instituto México, La Escuela Normal del estado y otras, además de una gran cantidad de fraccionamientos amurallados para familias de clase alta y media alta, tres plazas comerciales y de servicios para estas poblaciones.

A pesar del largo tiempo de explotación y uso, esta zona no representa una fuente de empleo para la gente de San Andrés, que solo consigue trabajo realizando tareas de albañiles, carpinteros, tapiceros de los bares, acomodador de carros para ubicarlos en lugares "seguros". Los 
ingresos para los sanandreseños, provienen más bien de la renta de estos espacios, que según algunos informantes perciben como una forma de mantener el control sobre el lugar y sus ocupantes, más el caso de los propietarios de estanquillos con venta de bebidas alcohólicas y aquellos que ofrecen una amplia variedad de servicios para estudiantes ubicados en esta misma calle. Un número cada vez más alto de espacios en renta para estudiantes en esta misma calle y las aledañas, cobran las rentas más altas de la cabecera municipal. Sin embargo, no cesan las protestas cíclicas de parte de sus propietarios a las autoridades, por lo abusos cometidos por quienes los frecuentan u ocupan que en ocasiones la comunidad reconsidera, con respuestas que no van más allá de suspensiones temporales:

Si, ya hubo una protesta hace 4 años, todos los de San Juan, por el basurero, el escándalo, por andar haciendo "disfiguros" en la calle, en los coches, diciendo que era un mal ejemplo para sus hijos, fueron a ver al presidente y les dijo que si tenían razón y que ya se iban a cerrar....entonces los cerraron como dos meses nadamás y luego.... Apareció otro, y otro, y otro más..(Mujer de 37 años, ama de casa, originaria)

Toda esta zona es permanentemente "mitificada" por las "historias" sobre crímenes, violaciones y las actualmente vinculadas al narcotráfico, que por otra parte se convierten en un atractivo más para algunos jóvenes y en una forma de mantener su "control" de parte de las familias originarias. Sigue siendo la sección más conflictiva de la cabecera municipal, que actualmente se extiende hacia el centro histórico en la modalidad de "botaneros". Una informante expresó lo anterior:

Todo lo que es ahorita por ejemplo, la industria restaurantera también, pero más como restaurant-bares no?, esos han sido demasiados, demasiados, están pues ahora no nomás en la 14 sino que se están viniendo más hacia el centro.. pero al no haber un reglamento comunicado donde delimite zonas históricas, donde tenga que ver también cuestiones de la infraestructura rural urbana, pues obviamente que les salen "oportunidades" y entonces se otorgan permisos(Mujer de 35años, profesionista, originaria)

Se comenta de la existencia de un consorcio, o grupo de amigos empresarios, juniors y políticos poblanos que desde hace muchos años han acaparado la zona mediante la apropiación de los bares, restaurantes y sitios de diversión más importantes, ejerciendo el control de la misma. Esto coincide con los rumores que ocasionalmente se han escuchado en Puebla, acerca de algunos políticos poblanos que han sido los verdaderos propietarios de algunos de estos sitios además de los de la zona dorada en la capital poblana, quienes mediante la imposición de reglamentos a modo, mantienen el verdadero control, ejercen poder, protegen e incrementan sus ganancias.

\section{La 12 Oriente:}

Otra de las transformaciones recientes más destacables en esta misma zona es sobre la 12 oriente, en la parte trasera de uno de los bares más grandes llamado El Tigre, se encuentran dos 
lotes ubicados uno enfrente de otro, de aprox. $2000 \mathrm{~m}$. cuadrados cada uno, que han sido destinados uno para estacionamiento de ese bar y el otro, que ya está ocupado actualmente por doce containers para arrancar otro proyecto similar al de Container City, que se promueve para uso habitacional. Se trata de un modelo de construcción que resulta económico, reubicable, y se levanta rápidamente sobre terrenos que pueden ser rentados como en este caso en el que existe el plan de colocar setenta containers que serán adaptados con todos los servicios, incluyendo internet, en el transcurso de dos meses, integrando una estructura de cinco niveles, un centro comercial con restaurant, cafetería, lavandería, etc. promocionándose su renta a $\$ 2,500.00$ por persona. Es importante señalar que su ubicación cercana a uno de los más grandes establos en producción, con una alta población de ganado lechero, y consecuente propagación de moscas y malos olores a los que no están acostumbrados los avecindados, seguramente provocará malestar e incomodidad a sus habitantes y podría convertirse en presión para su traslado. Sobre la calle transversal se encuentra un edificio de cuatro niveles y cuarenta departamentos con estacionamiento central, la aparición de nuevos bares, cafeterías y negocios de "tatoos" así como otros lotes destinados a estacionamiento vehicular

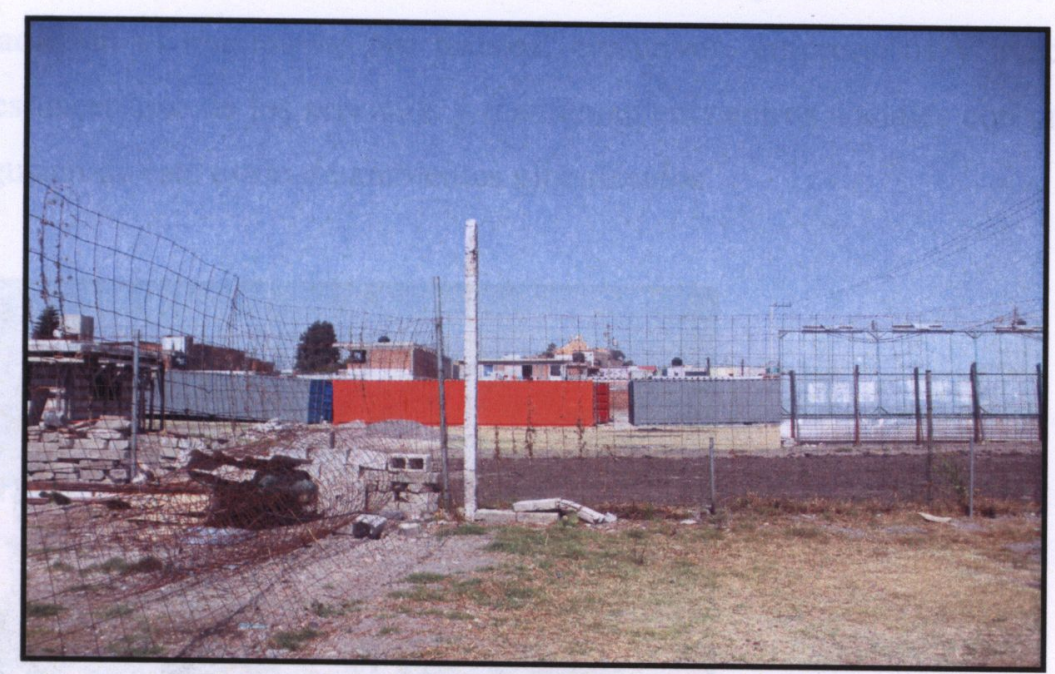

12 oriente: containers para conjunto habitacional

\section{Cruce "Cuatro caminos":}

El cruce de cuatro caminos es una referencia local, entendido como uno de los límites de la comunidad, que se encuentra integrado como un eje que comunica a esta centralidad que hemos 
denominado de diversión y entretenimiento, con la de servicios financieros y de franquicias y como acceso principal a la pirámide o a la inversa, como salida hacia Puebla, que muestra un alto y constante flujo vehicular que demanda el servicio permanente de un semáforo y un agente de tránsito. Desde hace muchos años, ha sido señalado como lugar "conflictivo" por haberse ubicado ahí justamente los primeros bares y "discos" famosos en los años setenta, funcionando aún como extensión de la zona de bares y restaurantes que inicia en la UDLA y llega hasta la pirámide.

A partir de este lugar y en dirección hacia la vía rápida a Puebla, arranca la zona de "franquicias" como "Tartlets", Starbuck's Coffee, Mac Donalds, Burguer King, Blockbuster, Italian Coffe, Oxxo y una zona de servicios bancarios, construida en los noventas que es renovada constantemente. Sobre la recta a $1.5 \mathrm{Km}$. se encuentra otro acceso a la Universidad de las Américas y sobre este trayecto, fraccionamientos de lujo, bardeados y vigilados, restaurantes, un centro comercial, bares y una gran discotheque por inaugurarse.

Esta zona funciona como un "centro" bancario, tecnológico e informativo, es constantemente visitada por estudiantes de la Universidad de las Américas y de otras instituciones educativas privadas, ubicadas en el municipio, por turistas, ejecutivos, empresarios y avecindados de San Andrés, quienes hacen uso de los servicios y mantienen encuentros sociales con grupos o personas similares que gustan de este estilo de ambientes globalizados.

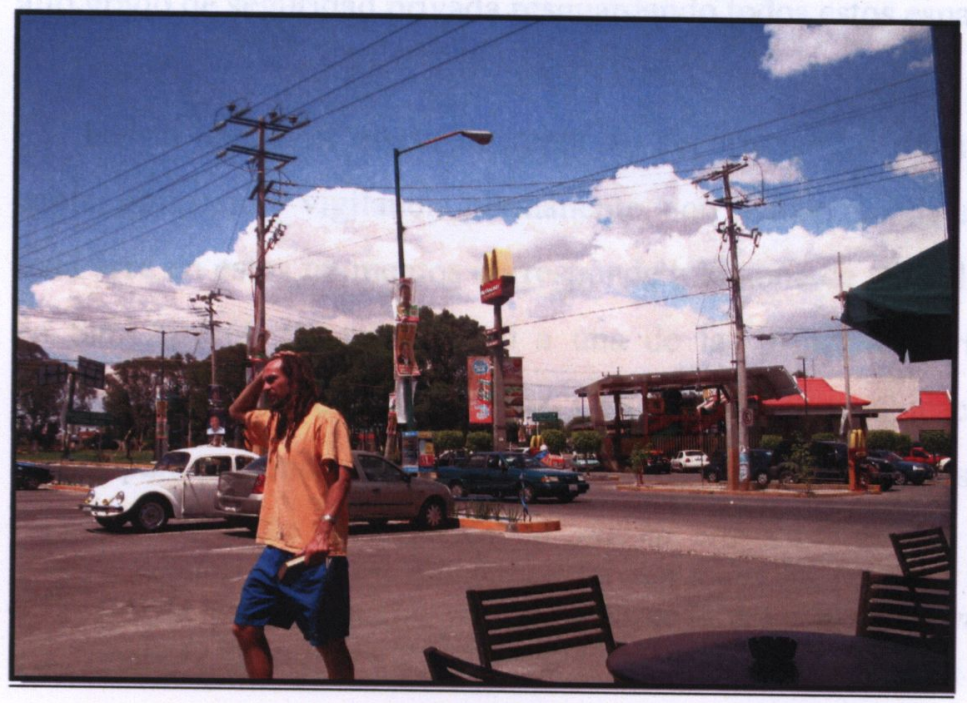




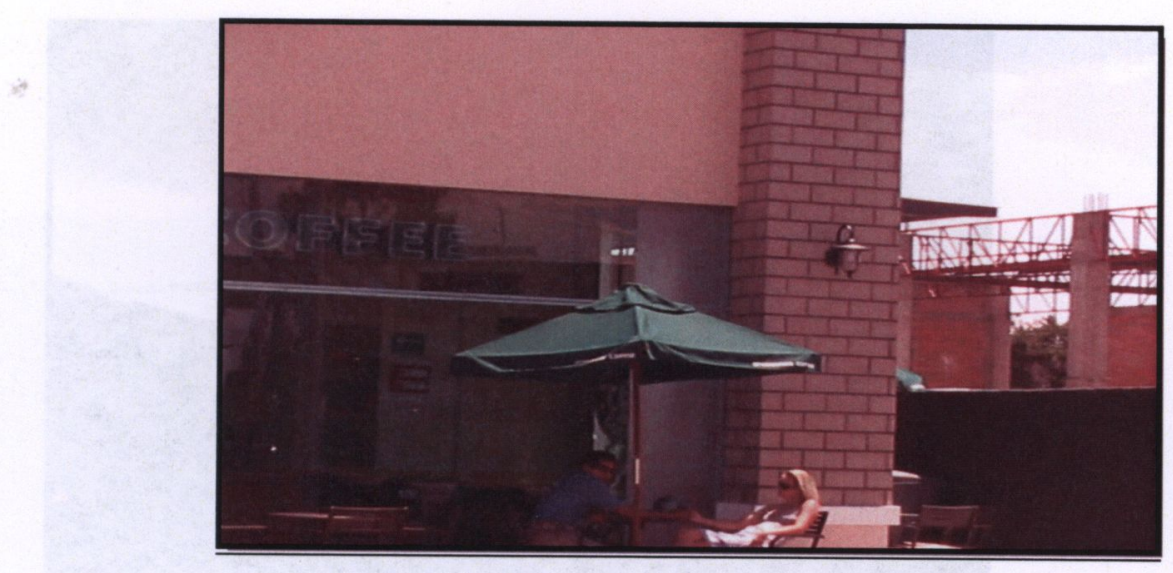

Starbucks Coffee

\subsection{Zona del periférico.-}

En el extremo oriente de la cabecera municipal, hacia el Periférico que comunica a la ciudad de Puebla con la autopista a México, se encuentra formando parte de la cabecera municipal de San Andrés, una amplia zona de desarrollo urbanístico desarrollada de unos cuatro años a la fecha, conocida en la localidad como zona del periférico. Fraccionamientos amurallados, residencias de lujo y edificios de departamentos de diversos estilos y corte modernista, destinados a familias de clase media alta o estudiantes de la universidad que se encuentra a unos metros de esta zona, son conectados por amplias vialidades adoquinadas. Se trata de una zona en las que se observa el más alto grado de seguridad privada resguardando todos estos espacios habitacionales.

Existe una gran oferta de renta de departamentos de lujo que incluye servicios de internet, cable, gimnasio y vigilancia permanente, con rentas que alcanzan hasta los 7,500 pesos mensuales. Esta área en estos momentos corresponde a la zona de más alto nivel económico de uso residencial en San Andrés. Su proximidad a una de las principales vías de comunicación, el periférico y autopista México-Puebla-Veracrúz- Oaxaca ofrece una ubicación estratégica que se ofrece como un "plus" para personas y familias con gran movilidad entre estos lugares.

La especulación, lo que ha provocado es que muchos inversionistas vengan y hagan condominios para estudiantes les den todos los servicios con internet, cuartos amueblados y todo esto no?. Entonces, ¿ porqué? Porque lo ven como una demanda no? Y Asi ha sido esa zona(Mujer de 35 años, profesionista, originaria). 


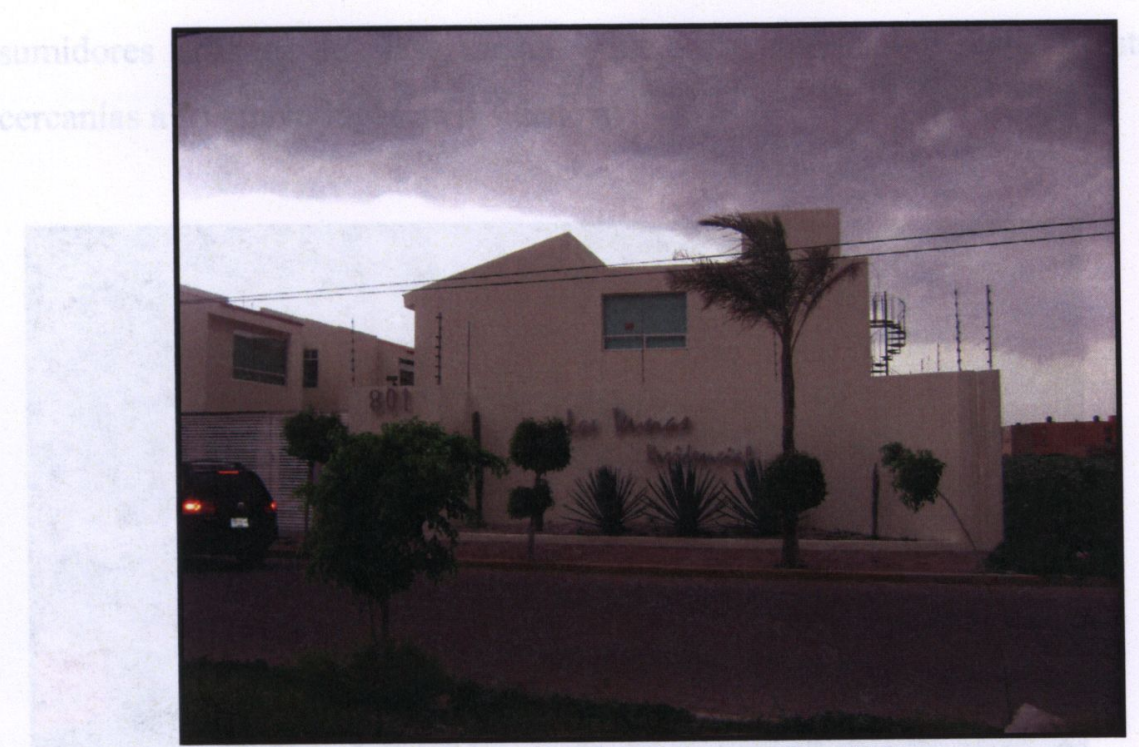

Conjunto Residencial, zona Periférico

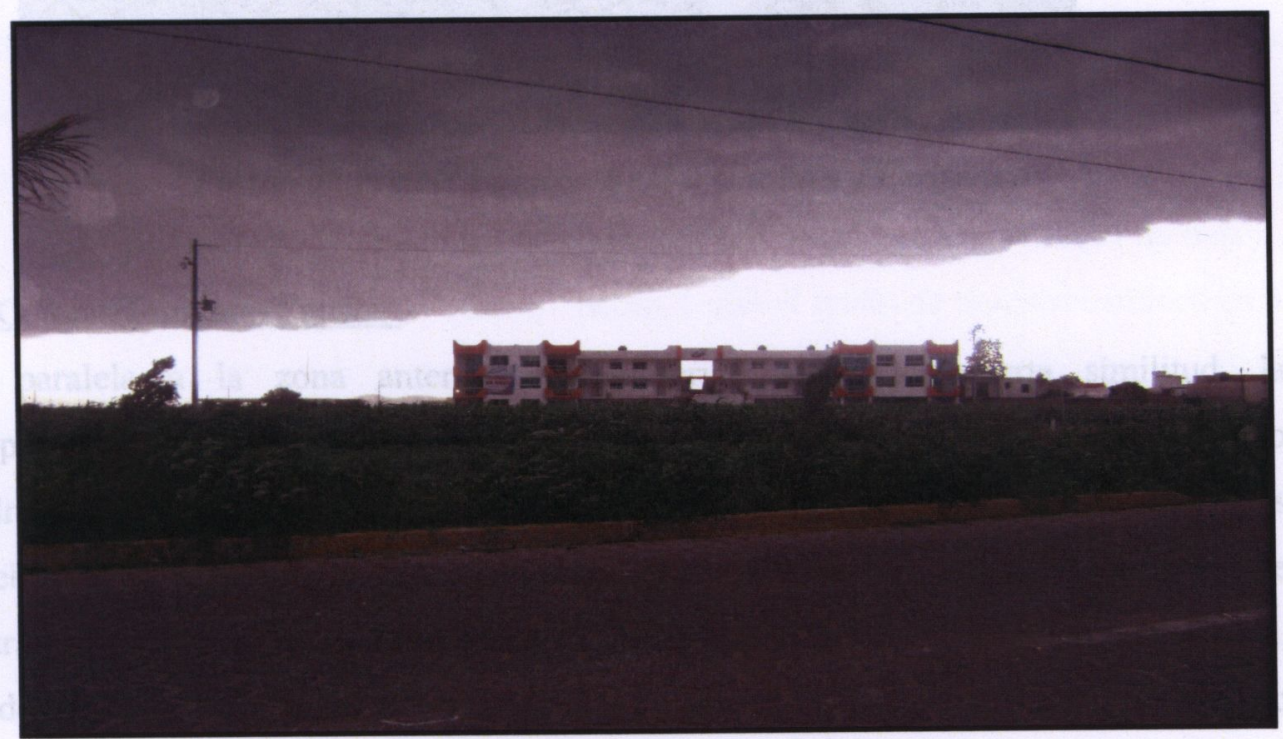

Edificios de Departamentos de lujo Zona periférico

Algo importante que agregar sería que la comunidad no pierde aún su asombro, por la rapidez del crecimiento de esta zona que la convierte en una de las transformaciones más importantes del paisaje de unos cuatro años a la fecha. Los residentes son avecindados, aunque todavía aparecen diseminadas algunas viviendas del estilo tradicional de familias sanandreseñas.

En esta zona se han ubicado pequeñas plazas comerciales, que funcionan como espacios de socialización y consumo, con negocios de comida rápida, cafés, farmacias y tiendas de autoservicio, 
dirigidas a consumidores urbanos de clase media y alta, que disfrutan y realizan este tipo de prácticas en las cercanías a su nuevo lugar de residencia:

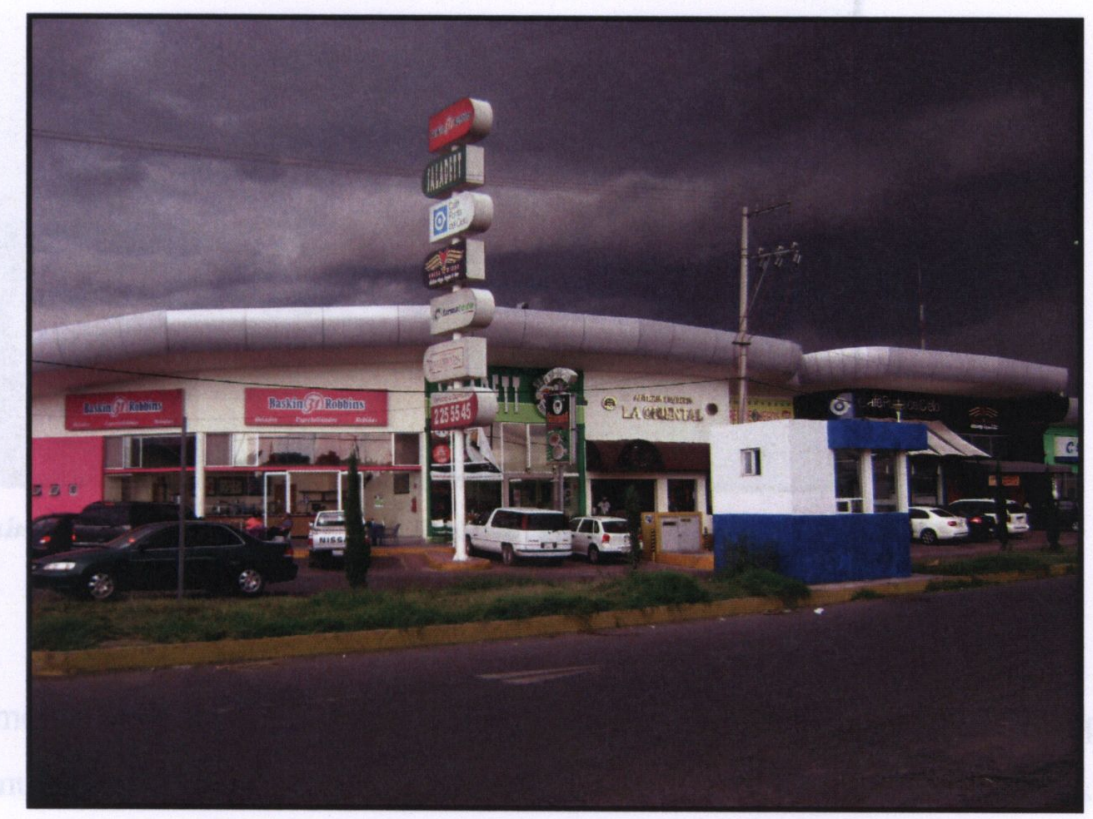

Plaza comercial: Camino Real a Cholula y Periférico

\subsection{Colonia Emiliano Zapata.-}

En forma paralela a la zona anteriormente descrita, guardando cierta similitud, la transformación principal consiste en la creación de un eje vial de cuatro carriles llamado "Camino Real a San Andrés", de reciente construcción, que comunica a este municipio con la sección más moderna de Puebla, ubicada en los límites municipales, con más alto valor del suelo, en la que se han instalado otras instituciones de educación media superior como la Universidad Iberoamericana, La universidad del Valle de México, El tecnológico de Monterrey, Instituto Andes, etc., sobre suelo sanandreseño, hasta llegar al centro comercial Angelópolis.

Un cometido con el cumple esta gran vialidad, es la de presentarse como otra opción vehicular hacia Puebla, que permita mayor fluidez en la circulación y ahorro de tiempo para quien desea trasladarse a la metrópoli, comunicando con la autopista hacia Atlixco, Morelos y Oaxaca. Aparentemente se trata de impulsar como una zona de servicios similar a la Recta a Cholula que actualmente resulta intransitable en horas pico y como una nueva ruta de transporte público hacia la capital del estado y del país puesta en marcha desde hace dos años. Aunque aún se observa una baja densidad de construcciones, resalta una gran disponibilidad de extensos terrenos en venta que algunas instituciones universitarias privadas ya han aprovechado. 


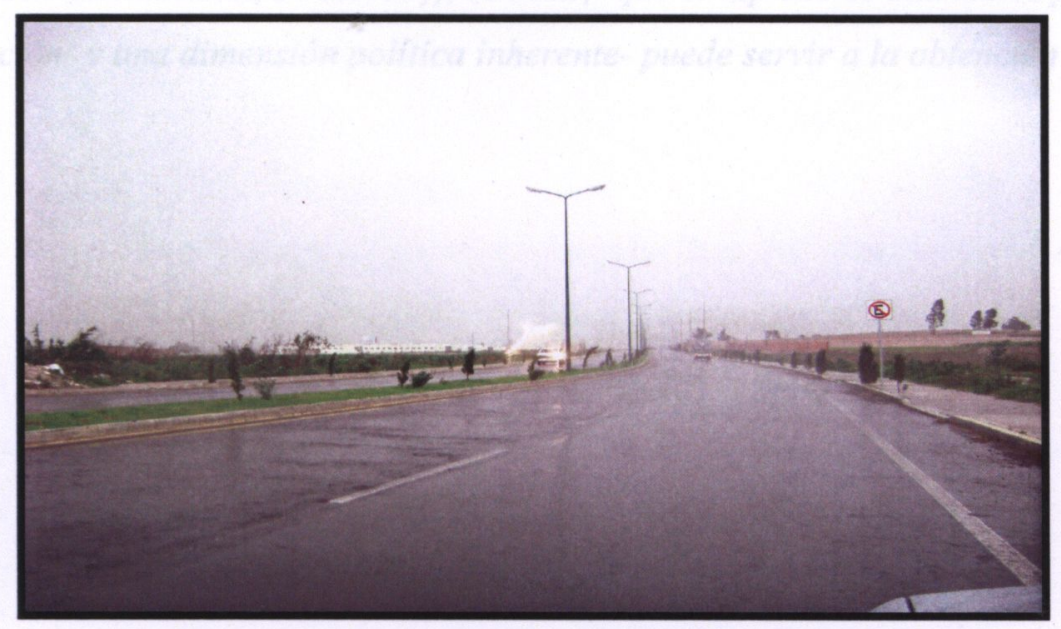

Camino Real a San Andrés(1), Col. Emiliano Zapata, 2009

Como testimonio de la percepción de cambios en el entorno y para reforzar lo expuesto en este capítulo, una mujer de 38 años, originaria, se refirió a lo que ha vivido a partir de los años setenta: el acceso al camión urbano lo hacían cruzando llanos, baldíos, y rapidito llegaban. Sus abuelos y padres, tenían sus propias hortalizas, gallinas, vacas, con eso alimentaron a sus familias de más de ocho hijos; Recuerda cuando se inauguró la recta a Puebla, como el inicio de muchos cambios en la comunidad. Ahora ya no pueden mandar a sus hijos solos a la escuela, tampoco los pueden dejar jugar en la calle, el tráfico ha ido en aumento y ahora el servicio de transporte público atraviesa todo el pueblo. Los hombres ya no siembran ni cuidan ganado, ahora trabajan en fábricas, son comerciantes, etc..A los hijos se les manda a la escuela y pide que estudien una carrera, además de aprender computación, inglés, etc., recomendándoles "aprender muchas cosas" para conseguir ingresos. Ella es madre de familia, originaria del pueblo y está empleada en una tienda de abarrotes, como parte de los cambios que obligan a trabajar a ambos cónyuges. Las fiestas continúan, pero ahora ya no participan como antes, por gremios de lecheros, agricultores, floricultores, etc., ahora son los gremios de taxistas, de comerciantes, de obreros, etc., quienes contribuyen con sus aportaciones.(Mujer de 34 años, empleada y ama de casa, originaria)

La caracterización de estos espacios y registro de cambios sobresalientes en los últimos cinco años, es importante para responder a los objetivos de este estudio, en una perspectiva socioespacial, interesada en la detección de actores principales como agentes de cambio y en las relaciones que establecen entre ellos y con el espacio, considerando a éste como capacidad, como contenedor de prácticas y posibilidad de acción(Corsin,Jiménez, 2001,2003, cit. en Authier y 
Bidou-Zachariasen, 2008:181)), es decir, "que el espacio es una teoría práctica-es también una acción- y una dimensión política inherente- puede servir a la obtención de las cosas"(Ibid, 181) 


\section{CONCEPTOS EXPLICATIVOS: Conflictos urbanos, gentrificación y patrimonialización}

\subsection{Conflictos urbanos.}

La importancia del análisis del conflicto en sus inicios para la antropología, partió de la idea de que los conflictos son parte de las relaciones sociales(Gluckman, 1958:s/n) y su estudio ha permitido el análisis de los procesos sociales por medio de los cuales se manejan. De acuerdo con Victor Turner, "el conflicto parece visibilizar los aspectos sociales, normalmente encubiertos por las costumbres y hace aterradoramente prominentes los hábitos de la rutina diaria(Turner, Victor, 1974, Cap. II:47)". Para el estudio de una comunidad en tensión por la gestión y apropiación de espacios, cambios en su uso y estado, por la implantación de proyectos externos o la imposición de decisiones gubernamentales, derivados de la expansión urbana, en la que la propia comunidad figura como actor ausente o marginado en las negociaciones o se muestra resistente al arribo de la ciudad, al urbanismo y la economía global que acompaña estos procesos, hemos considerado el encuentro de inconformidades, tensiones y situaciones de conflicto entre grupos que pretendemos analizar en la idea de que los conflictos son parte integrante de la acción pública y de la construcción de la relación de los habitantes con la ciudad o con al espacio urbano.

A la comunidad de San Andrés Cholula, "la ciudad se les vino encima", como lo expresa uno de los vecinos originarios que ha sido testigo de todas las transformaciones derivadas del crecimiento de la metrópoli y participante en acciones específicas de resistencia en momentos de tensión que en el pasado condujeron a diversas luchas y negociaciones. Si consideramos a la comunidad de San Andrés actualmente como un espacio contenido por relaciones sociales que despliegan fuerzas desiguales y luchas de poder con distintos actores que organizan sus acciones para su control y obtención de satisfactores, el estudio de los conflictos permite el conocimiento espacial, la identificación de actores, su ubicación, momentos, acciones y estrategias de acción y los intereses y valores que los movilizan para su comprensión y análisis.

\subsubsection{Las relaciones sociales y el conflicto.-}

En cada situación en particular, el análisis de los comportamientos de cada uno de los grupos interventores en el lugar de estudio, deberá considerar que el poder empresarial o gubernamental organiza sus acciones y en algunos momentos el conflicto no aparece, mostrando a la comunidad como una unidad en funcionamiento y equilibrio temporal, explicándonos su 
ausencia por la unión temporal de los sujetos beneficiados por el otorgamiento de diversos satisfactores(Gluckman, 1958: s/n). Considerando que pueden existir agrupaciones de individuos con intereses y valores distintos, Gluckman señala que conocer su adscripción grupal, acorde a tales intereses y motivaciones es útil para tratar de determinar cuál será su comportamiento en diferentes situaciones(Ibid, s/n) Otra consideración deberá ser la existencia de grupos dominantes que influyen o deciden las acciones y modos de cooperación, que a su vez están subdivididos en otros más pequeños, cohesionados por intereses, creencias, valores, tipos de empresas y diferencias de riqueza. El concepto que propone Gluckman de "identidades temporales", revela una estabilidad similar, que depende y es afectada por la relación ambivalente de conflicto y cooperación, además ayuda a explicar las incongruencias que se presentan cuando los individuos pueden vivir vidas coherentes a través de la "selección situacional", en una mezcolanza de valores contradictorios, creencias incompatibles e intereses y técnicas variadas (Ibid, $\mathrm{s} / \mathrm{n})$.

Gluckman encuentra que las contradicciones devienen en conflictos cuando aumenta la frecuencia relativa y la importancia de las diversas situaciones que se enfrenten en el funcionamiento de las organizaciones y que pueden ser parte de la estructura social determinando equilibrios y ajustes temporales, es decir, que los conflictos pueden ser previstos en relación a las variables de frecuencia e importancia de la situación que se enfrente y su articulación muestra una inserción en la estructura social que va guiando su funcionamiento. Esto es entendido a partir de la consideración de la frecuencia e intensidad de las situaciones de confrontación entre grupos que determinará la presentación de conflictos y su ausencia estará relacionada con la obtención de diversos satisfactores de parte de los participantes, que pueden ser los dominantes y conformar una subdivisión en otros más pequeños, siempre cohesionados por intereses, creencias, valores, tipos de empresas y diferencias de riqueza, conformando identidades temporales en un ambiente de conflicto y cooperación.

\subsubsection{Conflictos sociales.-}

Una interpretación de conflicto, útil para esta investigación es la de: "una comunidad o una sociedad local que resiste a una intrusión, a una imposición exterior" que Patrice Melé expone en su Proyecto sobre Conflictos, territorio y acción pública en México, para el caso de implantación de proyectos en situaciones rurales o indígenas(Melé, s/f: 12) y también como modelo de análisis en situaciones urbanas. Su utilidad la encontramos porque presenciamos a una comunidad rural de origen indígena, organizada por una estructura barrial y relaciones de parentesco, que crea fuertes 
vínculos con el territorio y espacios de significación, propios de una cultura territorializada, que recientemente es agredida por procesos intensos de urbanización impulsados desde el exterior, significando este hecho, un intento de apropiación legítima de su espacio de vida(Ibid, 12).

Un elemento que está en juego en las situaciones de conflicto y en particular en las situaciones rurales, es la construcción y/o reactivación de identidades locales(Ibid, 12). Ya hemos hablado acerca de la resistencia que las comunidades locales muestran de cara a la apertura económica, pero como comunidades abiertas ${ }^{10}$, que en el caso de estudio podría interpretarse a través del "ser pueblo en la ciudad" que explica Mariana Portal(Portal,1997:44) y que permite entre otras cosas la conservación y defensa de su territorio, que otros autores lo explican por ser "comunidades locales con capacidad cultural de dar sentido al devenir cambiante de su historia" (Duhau y Giglia, 2008: 365) en un proceso constante de relaciones con el exterior y reactivación de su identidad local.

Las representaciones sociales del espacio en juego son importantes de considerar como un conjunto organizado y jerarquizado de juicios, actitudes e informaciones que un grupo social dado elabora a propósito de un objeto. Se trata de un proceso de apropiación de la realidad y de su reconstrucción en un sistema simbólico, a partir de las visiones del mundo que desarrollan los grupos sociales y que dependen de su historia, del contexto social del cual proceden y de los valores a que se refieran(Abric, Jean Claude, 1996:11). De esta manera los conflictos, situaciones mediante las cuales las cualidades y valores adjudicados a un espacio, son renegociados en la interacción entre opositores y los actores públicos(Melé, s/f: 15), están mediados por las representaciones de los actores participantes acerca de la realidad que es apropiada y re-construída por cada uno de ellos y dan sentido a sus conductas. La valorización del espacio en juego de parte de los expertos políticos, es anclada localmente a discursos sobre los valores patrimoniales y medioambientales, constituyendo recursos estratégicos para las poblaciones nativas quienes juegan un rol cognitivo que les permite construir nuevas visiones del espacio en conflicto(Ibid, 15), que de alguna manera modifiquen sus representaciones.

${ }^{10}$ Habría que aclarar que el concepto de comunidad que funciona en este caso es aquel que considera en su interior oposiciones, de las cuales se desprenden la conformación de colectivos afectados por proyectos e interesados en la negociación de aquellos problemas que les afectan, considerando la posibilidad de su vinculación, para tal efecto, con grupos exteriores. 
El análisis de conflictos activos, como otra contribución para su estudio, permite interesarse en las condiciones de emergencia de colectivos que exigen el respeto del medioambiente o del patrimonio y sus relaciones con el régimen de acción pública(Ibid, s/f: 10). Las situaciones de acción pueden develar las modalidades de territorialización ligadas a conflictos y controversias, que en este caso provendrían de otros procesos vinculados a la urbanización del espacio de investigación, como la patrimonialización y la gentrificación y su forma de inserción, como procesos globales, en los conflictos sociales y formas de territorialización de acciones.

Resumiendo la propuesta de Melé que explica su inclusión en nuestro proyecto, como enfoque de análisis de este contexto, es que en los conflictos se construyen y reactivan identidades locales, se revelan las representaciones del espacio en juego y conocen las posturas y estrategias de los diferentes actores interactuando vinculados a los valores que se reconocen a dicho espacio, resultando además la emergencia de colectivos, situaciones de acción y modalidades de territorialización que propician las actuales modificaciones socio espaciales vinculadas a la globalización.

\subsubsection{Conflictos territorializados.}

El enfoque sobre conflictos que aborda este estudio, se sostiene en la idea de que "los conflictos son una forma de territorialización de la acción pública urbana y de la construcción de la relación o integración de los habitantes a la ciudad y al espacio urbano(Melé, 2001:15)". Cuando existen diferentes acciones, planes o medidas de protección que deben ser aplicadas a un territorio en particular, éstas conllevan un potencial conflicto, que se territorializa mediante acciones públicas entre los actores que ocupan, viven, se apropian o se quieren apropiar de ese territorio.

La tesis de Melé que tratamos de corroborar en nuestro estudio, es que a partir de que los conflictos:

- Permiten ver en la implantación de proyectos, momentos en los cuales se visualizan las acciones de grupos diversos que generan ésa acción, al igual que los conflictos en su aplicación.

- Contribuyen a la construcción/reactivación de identidades y permiten renegociaciones entre grupos acerca de las cualidades y valores del espacio en juego, así como la reconstrucción de las representaciones que legitimen la movilización o demanda.

- Los actores ecológicos y políticos que anclan los conflictos a los valores patrimoniales y medioambientales, se convierten en recursos estratégicos para las poblaciones 
movilizadas(locales) y juegan un rol cognitivo que incide en su visión del espacio en conflicto.

A pesar de que el espacio en juego se percibe fragmentado, con actores y proyectos dispersos en objetivos distintos, que visualizan y construyen representaciones diferentes acerca de las cualidades y valores de dicho espacio, los conflictos entre grupos, autoridades y la comunidad, serán momentos en los cuales se reconstruyan las representaciones y la relación intergrupal se defina incluyendo a la comunidad, anclándose a discursos que legitimen sus demandas e intentando acciones territorializadas que los identifiquen y muestren los recursos que dichos actores poseen y su efectividad.

Si consideramos que "el momento del conflicto es la forma que toma la negociación con los actores ausentes de los procesos de construcción de la acción pública(Ibid, 16)", la comunidad de San Andrés, generalmente es el actor ausente en el caso de implantación de proyectos interventores en su territorio, detectando que solo en ocasiones se presenta como una organización comunitaria interesada en defender sus límites territoriales con el estado de Puebla o consensar cuando se presenta una oferta atractiva de compra de terrenos, de parte de algún comprador empresarial, con el resto de sus integrantes, ante la cual se responde con un primer planteamiento, que puede abrir una etapa de negociación, en los siguientes términos: "ustedes quieren comprar, yo.... no quiero vender"

Podríamos definir al actual, como un momento controversial, en el que los discursos de los diferentes actores participantes que aparecen en las entrevistas realizadas, son básicamente opuestos y sus visiones distintas reflejan afectaciones, deseos y expectativas que tienen que ver con su condición de sujeto social en el lugar. Expresan cómo se sienten con los cambios urbanos recientes, con el incremento de relaciones con la diversidad, con la acción pública local o con el orden jurídico de los bienes públicos, siendo posible en estas condiciones prever que los conflictos sociales derivarán de la construcción de su relación con este nuevo contexto.

Los conflictos o controversias entre habitantes y actores públicos de acuerdo con Melé, podrán mostrarnos:

- Oposiciones entre grupos y actores políticos

- Reivindicaciones de habitantes y usuarios como petición de derechos. 
- Conflictos más difíciles de identificar o de construir: conflictos entre actores públicos. Se trata de plantearse el problema de determinar en qué momento tensiones y oposiciones, se vuelven conflictos abiertos ${ }^{11}$

Insistimos en que los conflictos urbanos al ser estudiados revelarán elementos de gran importancia para el análisis planteado en esta tesis como: lo que está en juego en el territorio, apropiaciones, voluntades de apropiaciones y oposiciones entre usos; representaciones de la ciudad, de la naturaleza o del ambiente y de lo que debe ser la acción pública urbana; los recursos que poseen los actores como capacidad de movilización, pero también la capacidad de movilizar recursos o discursos del orden jurídico.

En este sentido, correspondiente a otra etapa del conflicto, encontramos como un recurso de análisis específico que aparece durante el proceso : "la traducción o transcodificación", que de acuerdo con Lascoumes, citado por Melé, entre un conflicto que puede tener un origen muy local y elementos más generales de legitimación. (Ibid, 1994: 17). Entendiendo con esto que se puede considerar que los actores en conflicto hacen una transcodificación entre lo que es el conflicto que tiene un objeto muy local, que puede ser sobre el entorno de vida, oposiciones a construcciones de carretera, etc. y el hecho de presentarse en la escena pública con discursos que apelan a otra legitimidad, llamando a este recurso un "ascenso en generalidad" en el sentido que los autores Lafaye y Thévenot se refieren (Ibid, 17) . La salida de los conflictos reviste especial importancia para su estudio ya que "implica la aceptación de un consenso sobre una cierta forma de acción pública urbana o medio ambiental, buscando subrayar el papel del orden jurídico y de los discursos alrededor del orden jurídico(Melé,2001:18)".

A partir de que una de las formas privilegiadas del análisis de la relación entre grupos sociales y el orden jurídico es el conflicto, el cual toma un lugar cada vez más importante por su multiplicación y actualización en las luchas urbanas, como el de la gente movilizada alrededor de su calidad de vida, recurso clasificado como de tipo $\operatorname{NIMBY}^{12}(I b i d, 18)$, en el lugar de estudio es

\footnotetext{
${ }^{11}$ Nota: No todas las tensiones y negociaciones entre actores se tienen que analizar como conflicto, de acuerdo con Melé, el elemento que tiene un valor heurístico es el estudio de momentos de conflictos declarados y de los discursos ligados a estos conflictos o manifestación de oposición.
}

12 El efecto NIMBY, es un término sajón que significa: "Not in my back yard"(No en mi traspatio), al cual se suscriben Asociaciones que se oponen a proyectos de ordenación territorial. Este aparece en mucha de la bibliografia sobre "gentrificación" y comúnmente aplicado por los geógrafos. 
posible analizarlo desde las nuevas modalidades de procesos segregacionistas y de exclusión social como la gentrificación y patrimonialización, ya instalados en el área. Los conflictos en su dimensión temporal demuestran que pueden ser analizados como: 1) momentos de dramatización de la relación entre los habitantes y el orden jurídico urbano-ambiental y 2) momentos fuertes del debate público que logran abrir otros de debate alrededor de la ley y la acción pública. En este sentido encontramos la propuesta de muchos de los avecindados para la posible solución de situaciones de conflicto con los originarios, del establecimiento de un nuevo orden jurídico que les permita resolver las situaciones problemáticas inesperadas de su condición actual como residentes de la comunidad.

\subsubsection{Conflictos por el espacio.-}

Anteriormente nos referimos al espacio, como capacidad, como contenedor de prácticas y posibilidad de acción(Corsin,Jiménez, 2001,2003, cit. en Authier y Bidou-Z, 2008:181), es decir, "que el espacio es una teoría práctica que- es también una acción- y una dimensión política inherente- puede servir a obtener las cosas" (Ibid, 181), entendiendo entonces que su transformación, apropiación e interacción actual nos están revelando cómo son estructuradas por relaciones de poder, que en él se afirman y ejercen, que de acuerdo con Bourdieu:

Es uno de los lugares donde se afirma y ejerce el poder, y sin duda de forma más sutil, ... la violencia simbólica como violencia inadvertida: los espacios arquitectónicos, son en verdad los componentes más importantes a causa de su misma invisibilidad, de la simbólica del poder y de los efectos totalmente reales del poder simbólico(Bourdieu, :122) ${ }^{13}$

En cuanto a la relación existente entre los conflictos por el espacio y los efectos "de lugar", para estar en condiciones de entenderla necesitamos considerar el papel que juegan otros elementos del contexto, situados en el marco del orden urbano que los contiene y propicia su

desencadenamiento(Duhau y Giglia, 2004:266), refiriéndose al orden urbano, al cual definen como:

El conjunto de normas y reglas tanto formales(pertenecientes a alguna jerarquía del orden jurídico) como convencionales a las que recurren los habitantes de la ciudad explícita o tácitamente en el desarrollo de las prácticas relacionadas con los usos y las formas de apropiación de los espacios y bienes públicos o de uso colectivo que, más allá de la vivienda, son los elementos constitutivos de la ciudad(Ibid, 258).

Estos autores formulan la hipótesis de que para su comprensión y explicación conviene tener en cuenta al menos cuatro órdenes de fenómenos y su interacción:

- Las diversas formas en que se encuentra organizado el espacio urbano

\footnotetext{
${ }^{13}$ Ver Bourdieu, Pierre, Efectos del Lugar, p.122
} 
- Las modalidades que da la propia expansión urbana y sus modificaciones específicas

- El orden formal(jurídico) que establece y organiza los diferentes usos del espacio

- La proliferación de prácticas que implican la vigencia de normas y reglas convencionales que se oponen de modo flagrante a las emanadas del orden formal.

Lo anterior demuestra la importancia del contexto en el análisis de los conflictos por el espacio, que establece su relación con la forma en que el orden urbano se establezca en el mismo, el uso del espacio y bienes públicos (Ibid, 266). Nuestro espacio de análisis se ubica en la clasificación que estos autores construyen como espacio ancestral, con problemáticas complejas entre otras cosas como el uso del suelo, las identidades y su construcción, las tradiciones en la contemporaneidad(Safa, 1998:120) y sus relaciones con el área metropolitana y más recientemente, el arraigo histórico y alta plusvalía del terreno, apreciados por los citadinos que lo convierten en espacio disputado, en este caso atravesado por procesos de gentrificación y patrimonialización.

De tal modo que los conflictos por el espacio, se presentan por la alteración producto de la convivencia vecinal con sujetos de clase media y alta, turistas o paseantes que hacen un uso diferente de espacios y bienes públicos y por los derivados del proceso de patrimonialización, y consecuente reglamentación de los mismos, es decir, por la producción de nuevas relaciones con el espacio urbano. Lo anterior nos lleva a considerar que en esta conformación de nuevos espacios al interior de la cabecera municipal, surgen a la par nuevos conceptos de orden urbano al interior de cada uno de ellos, que tendrán que ser contextualizados para su conocimiento y posible vinculación con los conflictos que de cada uno de ellos puedan derivar. La hipótesis propuesta por Duhau y Giglia(Ibid, 267) acerca de que existe una significativa correspondencia entre: cada forma de producción del espacio urbano, las prácticas y apropiación de uso de éste, la morfología social del espacio habitado, los conflictos típicos por el espacio y la gestión urbana, será parte de este estudio que hará un análisis espacial de esta relación.

\subsection{Gentrificación.}

En los años sesenta Ruth Glass crea el término de gentrificación para designar un proceso o conjunto de procesos que incluía mejoramiento físico del vecindario cambio de inquilinos a 
propietarios, aumento de precios y desplazamiento de la clase trabajadora existente por las clases medias:

Uno a uno, muchos de los barrios de la clase trabajadora de Londres han sido invadidos por las clases medias-altas y bajas. Callejuelas y chalets derruídos y modestos-de dos cuartos arriba y abajo- han sido tomados cuando sus contratos de arrendamiento han expirado, y se han convertido en residencias, elegantes y caras.... Una vez que este proceso de gentrificación comienza en un distrito se va rápidamente hasta que todos o la mayoría de los ocupantes de la clase trabajadora son desplazados y el carácter social completo del distrito se cambia" (Ruth Glass, 1964)

En español se han usado distintas expresiones para denominar este mismo fenómeno tales como "recualificación social", "aburguesamiento", "aristocratización", "gentrificación" y "elitización residencial". Luz Marina García Herrera(García, H., 2001: s/n), propone el de "elitización", por considerar que este vocablo recoge la esencia de clase inherente al proceso, a la vez que permite la inclusión de los segmentos medio-altos que son una parte muy importante del mismo y lo explica de la siguiente manera:

La noción de élite alude al protagonismo de un grupo especifico, privilegiado, con capacidad de influencia social, de liderazgo y de influir en la toma de decisiones. Los miembros de la elite, como expuso hace ya tiempo en su estudio clásico Pareto(Pareto, 1979, cit. en García, 2001, $s(n)$, participan de todas o de alguna de las siguientes cualidades: importante nivel de riqueza, pertenencia a ciertas familias relevantes y/o buenas conexiones sociales(Ibid,)."

El término gentrificación ha sido entendido como aburguesamiento, ennoblecimiento y se refiere a la alteración de la composición social original de determinadas áreas de una ciudad como consecuencia de programas de recalificación de espacios urbanos estratégìcos, cuando estos entrañan intereses inmobiliarios, empresariales y financieros. Significa la expulsión de habitantes de zonas urbanas degradadas, que pertenencen a clases sociales menos favorecidas, a consecuencia de la revalorización de la zona a partir de una intervención urbanística.

Neil Smith ha sido quizás el más prolífico y más elocuente teórico de la gentrificación, desde los años setenta, periodo durante el cual se emprendió la reconquista de la ciudad central, por la afluencia, en muchas ciudades americanas y europeas, que se dice haber llegado, ido y resurgido. La literatura de la gentrificación se ha centrado en dos debates(Smith,2002:s/n): primero, si este fenómeno ha sido conducido principalmente por el movimiento de capital en busca de ganancias o por las preferencias de consumidores de una nueva clase media( integrada por los llamados yuppies y otros); segundo si los patrones concurrentes de la gentrificación (o desgentrificación), a lo largo de tres continentes y durante dos décadas, pueden ser explicadas por una teoría general, o mediante 
experiencias locales divergentes que intentan socavar la generalización. En resumen, los escritos de Neil Smith han asumido la primera postura más significativa en la presentación de su tesis de "vacío de renta"14 para explicar la gentrificación a escala global:

Las verdaderas ciudades globales pueden ser las economías metropolitanas de rápido crecimiento de Asia, Latina América y en un menor grado, Africa, tanto como los centros de "mando" de Europa, Norteamérica y Japón. Pero este proceso que inicialmente emergió como esporádico, extraño, anomalía loca, ahora está profundamente generalizado como una estrategia de substitución de la política liberal urbana, no más instalada o restringida a aquéllos países. El impulso atrás de la gentrificación es ahora generalizado, su incidencia es global y está densamente conectado a los circuitos de capital global y circulación cultural(Ibid, $\mathrm{s} / \mathrm{n}$ )

Después de los años setenta, la gentrificación ha cambiado de ser un proceso marginal y fragmentado en el mercado de la vivienda a uno de larga escala, una política urbana sistemática y deliberada. Se ha profundizado como una estrategia general de construcción en la ciudad que acompaña no solo al mercado residencial, sino también a la recreación, al empleo y la economía cultural. También se ha extendido geográficamente a Latinoamérica y Asia en ciudades como Shangai y Beijing, por ejemplo, desplazando a cientos de miles de residentes de la clase trabajadora y pobre. Como una estrategia urbana generalizada, la gentrificación se entrelaza con el interés de los empresarios de la ciudad, desarrolladores y terratenientes, pero también incorpora a empleados y a instituciones culturales y educativas que dependen de una fuerza laboral de profesionistas.

Aunque ha sido mayormente estudiado en los países industrializados, no deja de ser un gran fenómeno que se ha comenzado a estudiar desde la década del 2000 en países como Brasil y Argentina (Herzer,2001; De Pablos Ramírez \& Tobar, 2002; De Queiroz Ribeiro et al., 2004; entre otros)(Nates, Cruz, 2008:8)

Otro cambio que sufre la gentrification es cuando "Los estados nacionales, ayudados por organismos multilaterales, liberalizan los mercados y buscan forzar el cambio de políticas para crear nichos de inversión privada(Sabatini, entrevista)" y la gentrificación se masifica porque entran las empresas inmobiliarias que hacen edificios como los antiguos multifamiliares: "la gentrification se convierte en un panorama masivo de la economía urbana". Lo que vincula estos dos argumentos es el cambio, de una escala urbana definida de acuerdo a las condiciones de la reproducción social, a otra en que la inversión del capital productivo tiene prioridad definitiva, evidenciándose que los gentrificadores actualmente no están deseosos de invertir capital social en el

\footnotetext{
${ }^{14}$ Nota: El vacío de renta es la creación de una posible reinversión provechosa a través de la devaluación del capital en la ciudad central
} 
área y si lo están en que sus relaciones sean casi completamente con "gente como nosotros"(Butler,Tim, s/f $)^{15}$.

Pero esta gran escala de estrategias también son integradas con muchas más iniciativas locales, y los empresarios de la ciudad alrededor del mundo se han enamorado de la idea de la "ciudad creativa". Como un asunto de estrategia amplia urbana, ellos intentan atraer a la tan llamada clase creativa de artistas, intelectuales, del espectáculo, diseñadores, ingenieros de alta tecnología, a vecindarios para la gentrificación. Cuando la renovación urbana se vincula a la reputación hippie e incluye la construcción de condominios, atrae también la presencia de yuppies, que quieren vivir en esa atmósfera elevando las rentas y desalojando a los artistas y residentes de más bajos ingresos, con frecuencia a minorías raciales/étnicas, cambiando el carácter social del vecindario. También implica la yupificación de negocios locales del gusto yuppie como restaurants sushis, Starbucks, etc., que llegan a reemplazar a los negocios locales que son desplazados por las rentas más altas.

Para captar la dimensión social de este fenómeno, encontramos una afirmación de Bourdieu (Bourdieu, 1988:69,70) con relación a los grupos privilegiados y su relación con el espacio, como factor de diferenciación social "estas elites disponen de suficiente capital económico y cultural para producir o modificar espacios a los que incorporan una identidad social excluyente. También la nueva clase media busca un entorno donde expresar su estilo y gusto distintivo de clase, de ahí la conversión de los barrios populares y viejas zonas industriales en objeto estéticamente relevante para los mismos(Améndola, 2000:s/n)".

El registro de formas en que los diferentes actores participantes en este proceso contribuyen a él(Collet, 2008:125) y su manifestación en conflictos urbanos, develan situaciones de acción y modalidades de territorialización, que se presentan de manera discontinua en el espacio(Sargatal, 2001:s/n). A partir de lo anterior, encontramos importante el uso de la "extensión" de la definición de gentrificación como:

(...) aquella que designa hoy también, procesos de renovación social y de transformación de edificios observables en un barrio así como las políticas puestas en marcha por ciertas ciudades para atraer a su centro a las élites de la clase creativa(Florida, 2002, cit. Authier y Bidou, 2008:14) en un triple contexto de reestructuración de las economías capitalistas, de concurrencia interciudades y de difusión de nuevas teorías de desarrollo económico local, recurriendo a veces para

${ }^{15}$ cus.sagepub.com/search.cgi?journal $=X \& q u e r y=$ gentrification 
eso, a operaciones de construcciones nuevas- las cuales hacen referencia a la expresión reciente de "new build gentrification"16 (Authier y Bidou-Zachariasen, 2008:14)

Para explicarnos la creación de proyectos que contribuyen a la gentrificación a través de la idea de potenciar una rica e intensa forma de vida, Alejandra Leal Martínez, refiere el caso del centro histórico de la Ciudad de México(Leal Martínez, 2007: 29), donde se ha impulsado un proyecto que tiene como característica, su repoblamiento, promoviendo el desarrollo habitacional para sectores de clase media alta y describe a los planificadores que están a cargo de esto, actores de gran importancia en la selección y definición de las características de estas intervenciones, mediadas por modelos globales de renovación urbana en los cuales las industrias culturales han desempeñado un papel central. Aunque si bien, las condiciones socioeconómicas y culturales de la ciudad de México no son en nada semejantes a las de ciudades como Londres, NY o Barcelona, sirven de modelo, inspiración y punto de referencia importante para los planificadores y consumidores de este corredor cultural.(Ibid, 30) Por un lado proporcionan conocimientos y técnicas para desarrollar una operación de bienes raíces rentable y por otro, son el origen de una identidad urbana y de formas de consumo que interpelan a grupos sociales similares alrededor del mundo. De esta manera:

El planificador se distancia del espacio local en donde pretende implantar estos modelos. Su mirada se concentra en algunos edificios y en otros, elementos arquitectónicos como las plazas públicas que potencialmente pueden ser resignificados y pasa por alto las relaciones sociales que conforman al (lugar)(Ibid, 30)

En la construcción de imaginarios se privilegia la realización de deseos y se eliminan de ellos las características de los pobladores originarios del sitio elegido para repoblar. Algunos otros objetivos como el rescate del abandono, del deterioro y la criminalidad los asisten en esta tarea y las ideas sobre lo que:"constituye un espacio vivo y habitable y sobre cuáles son sus usos apropiados y correctos"(Deutsche y otros cit.en Leal, 2001:31). Leal explica que este tipo de procesos son actos de violencia material y simbólica, que generan más violencia al ignorar las formas de vida y relaciones sociales que lo conforman y el incremento del valor del suelo que ocasiona el desplazamiento de sus habitantes más vulnerables resumiéndolo como un acto de transformación de un lugar, fundamentado en la carga simbólica, patrimonial e histórica, para la atracción de clases medias mediante la construcción de espacios como nuevos lugares de consumo, galerías, cafés. El resultado de lo anterior se refleja en el peligro del entorno, por ofrecerse un nuevo estilo de vida que resulta ajeno para la población originaria y en una desestabilización del área como espacio

\footnotetext{
${ }^{16}$ La extensión de la noción de gentrificación es en efecto acompañada de una multiplicación de expresiones al seno de la que diferentes epítetos son acogidos por el término gentrificación: "gentrificación esporádica", "gentrificación marginal", "gentrificación emergente", "gentrificación de consumo", "gentrificación institucional", "gentrificación estratégica", "política de gentrificación", etc.(Ibid, p. 14)
} 
residencial similar a un acto de colonización(Ibid, 37). Los residentes originarios viven esta acción con tensiones y contradicciones y de manera involuntaria manifiestan los efectos de violencia que acompañan a este proceso. Podríamos resaltar una de las características que señala la autora para el caso que nos ocupa y que amerita comentarse, el hecho de que son procesos conformados por múltiples intereses económicos y políticos, pero también por los deseos, expectativas y miedos de los grupos sociales que llegan atraídos por ellos y que no se toman en cuenta.

Los diferentes fenómenos identificados actualmente por el término gentrificación, obligan según algunos autores, a deconstruirlo(Bourdin,2008:23), para saber si deben ser analíticamente asociados o disociados, o bien responder a la pregunta de si se debe reservar para situaciones que correspondan al modelo formalizado por Ruth Glass. Ahora se conocen nuevas características de la gentrificación en diferentes ciudades, sus antecedentes sociales y proclividades culturales así como la naturaleza del proceso de transformación del área residencial. Las elecciones y preferencias de los gentrificadores se dan argumentando que es el capital y las instituciones del mercado capitalista y desarrolladores, agentes estatales reales, prestadores de hipotecas y otros quienes tienen la llave para entenderlo, llegando a la conclusión que es determinado por las necesidades de producción. (Ibid.). De acuerdo con Beatríz Nates Cruz, en su investigación sobre este fenómeno en Manizales, Colombia, sus indicadores son los siguientes:

1) Aumento desproporcionado de las entradas y del nivel de educación en comparación de la media de la ciudad. 2) Aumento de la inversión privada

3) Aumento del precio medio de la venta de espacios residenciales y comerciales.

4) Aumento de los alquileres comerciales y del hábitat. 5) Aumento en las ventas de bienes de uso residencial como comercial. 6) Creciente aumento de las tasas de expulsión y de demandas, situación propiciada por los propietarios que buscan por esa via una expulsión de los inquilinos.

7) Elevación del número de permisos para construir(Nates, Cruz, 2008:8)

\subsubsection{Gentrificación rururbana:}

La gentrificación como un proceso de transformación de áreas y dislocamiento social de residentes rurales, ha sido considerada a partir de los noventa por Martin Phillips y otros autores en Inglaterra y Nueva Zelanda y recientemente en Colombia, denotando en los resultados de sus investigaciones los vínculos entre la gentrificación rural y la urbana, al igual que cambios socioterritoriales con dinámicas y dimensiones propias, incluídas en la agenda municipal que muestran principalmente que este proceso en las áreas rurales evidencia nuevas formas de elitización y ampliación del radio de poder y control social de los gentrificadores.

La importancia de estudiar la rururbanidad a través de procesos de gentrificación está en que este concepto hace referencia a cómo se produce una recomposición territorial y social de la contemporaneidad tanto urbana como rural, aunque los primeros estudios hechos por anglosajones (Schmitt, 1969; Smith, 1996; Phillips, 1993) han estado ligados más a trabajar la gentrificación en ciudades(Nates, Cruz, 2008:7) 
Como factores que determinan la instalación de este fenómeno en comunidades rurales, se señala la situación de dificultad económica y social y de cohesión social que actualmente atraviezan, lo cual permite dejar en manos de los recién llegados su instalación en el lugar y la demanda creciente de "bienes rurales" que deben consumir los citadinos de los sectores medio y superior, todo ello permite y facilita este proceso llamado también en este contexto: "greentrificación" por Martin Phillips(Phillips, Martin,2008:s/n ).

El principio de la gentrificación urbana, rural o semi rural es el mismo en los tres casos: un espacio donde el precio de la tierra y de la vivienda es atractivo, se vuelve objeto de deseos y apropiación por parte de poblaciones exteriores. El mito del pueblo, adquiere nuevos valores simbólicos y da la sensación de tranquilidad y amplitud, permite dar vuelta a vivir en el campo a través de lo rururbano pero ahora desde la gentrificación.

La puesta en escena del concepto de gentrificación en los cambios recientes de la estructura de la economía de las sociedades actuales, asi como la urbanización creciente y la atracción de los citadinos por un estilo de vida rural, le han asignado a los lugares rururbanos nuevas vocaciones y nuevos usos cada vez menos agricolas y cada vez más residenciales(Nates, Cruz, 2008:11)

En este contexto la gentrificación se puede entender también como un proceso que funciona en un espacio caracterizado por una imbricación de actores sociales, económicos y ecológicos, ligados a negocios, políticas de alquiler y venta de vivienda, que permite la infiltración de poblaciones de alto o mediano poder adquisitivo y que consecuentemente ocasiona la transformación de áreas y el dislocamiento social de residentes rurales.
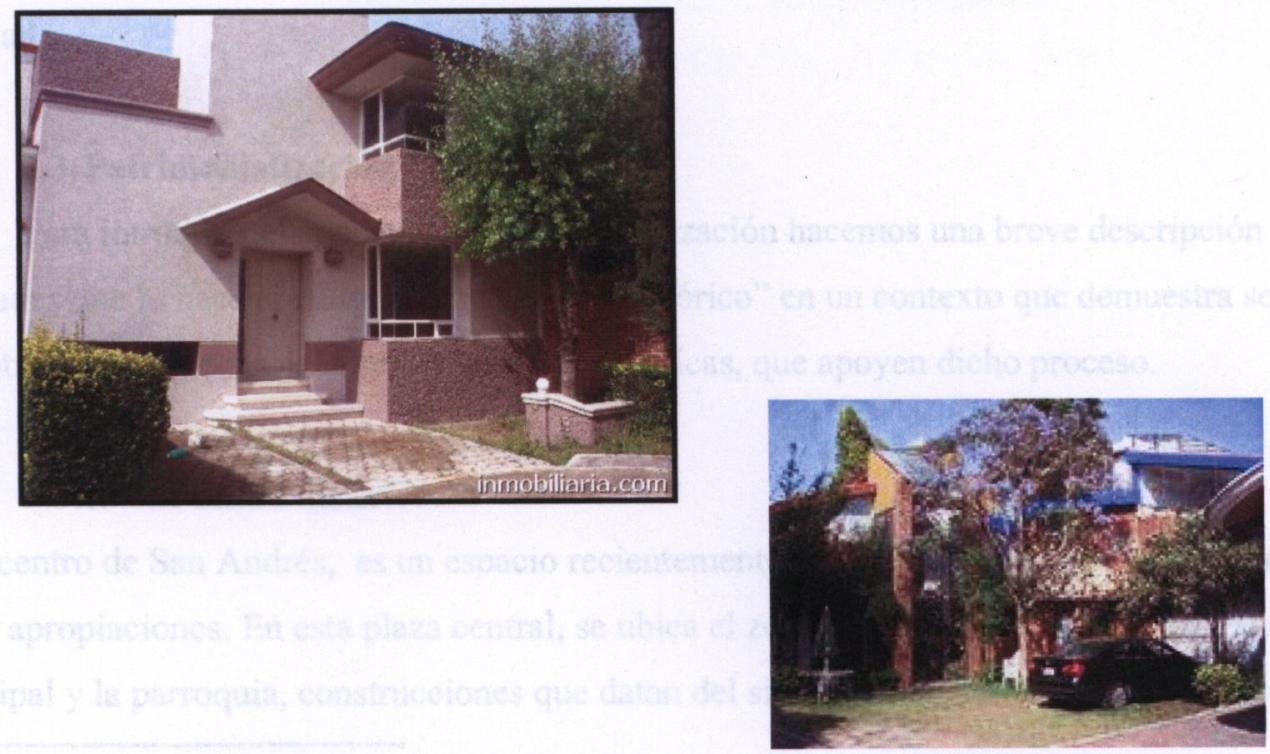


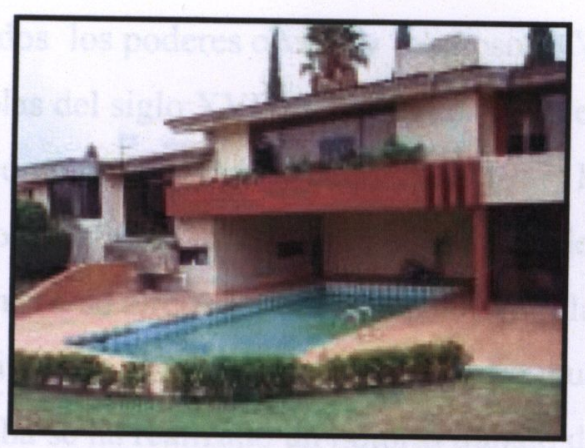

Residencias en venta, zonas gentrificadas

Fuente: página web, San Andrés Cholula ${ }^{17}$

Como teórico social con propuestas que tienen que ver con el estudio y análisis de fenómenos segregacionistas como lo es la gentrificación, Loic Wacquant sugiere que para construir mejores modelos del cambiante nexo entre espacio y clase, en la ciudad neoliberal, necesitamos reubicar la gentrificación en un marco analítico más amplio y acucioso, revisando el análisis de clase para captar la de-formación del proletariado postindustrial, resistiendo las seducciones de las problemáticas prefabricadas de política y dando un lugar preferencial al estado como productor de desigualdad socioespacial. En una postura crítica a los estudios sobre el tema, señala que el cambio de la denuncia a la celebración de la gentrificación, la ignorancia del desplazamiento de los residentes establecidos, y el enfoque eufemista en la mezcla social, proviene de un modelo más amplio de invisibilidad de la clase trabajadora en la esfera pública y en la investigación social. Este desdibujamiento del proletariado en la ciudad, afirma, es reforzado por la creciente heteronomia de estudios urbanos, conforme estos últimos devienen más vinculados a los problemas de las reglas en la ciudad.

\subsection{Patrimonialización}

Para introducir el concepto de patrimonialización hacemos una breve descripción del sitio y cualidades que lo hacen resurgir como "centro histórico" en un contexto que demuestra ser susceptible de la implementación de acciones públicas, que apoyen dicho proceso.

\subsubsection{El centro histórico:}

El centro de San Andrés, es un espacio recientemente renovado, con cambios en algunos de sus usos y apropiaciones. En esta plaza central, se ubica el zócalo, las oficinas de la presidencia municipal y la parroquia, construcciones que datan del siglo XVI al XVIII en las que se encuentran

\footnotetext{
${ }^{17}$ Rescatado el 14 de agosto de 2009
} 
instalados los poderes civiles y religiosos. Conserva la traza reticular propia de las ciudades españolas del siglo XVI: un conjunto de calles rectas organizadas de manera perpendicular con una plaza como centro (Domínguez, 2003:19) ${ }^{18}$. El área denominada “centro", incluye ocho barrios con edificios religiosos que honran a cada uno de los santos patrones y se extiende unas treinta manzanas a su alrededor hasta llegar, por el lado este, a la pirámide "Tlachihualtépetl", ubicada en los límites con el municipio de San Pedro, que incluimos en esta área. En un periodo de cuatro años a la fecha se ha realizado un notorio trabajo de remozamiento de fachadas de edificios, casa, calles y vialidades al interior de esta área, de parte de las autoridades locales preocupadas por su protección, por una estrategia de imagen y por la refuncionalización adecuada de algunos espacios acorde a las nuevas actividades derivadas de las transformaciones socioterritoriales en la cabecera municipal, que denotan un giro “(..) hacia el turismo, vinculado a la acción gentrificadora, que permite la recuperación del centro histórico para la promoción de empresas expulsando su vocación inicial, y afectando la fisonomía de la plaza, los actores cotidianos y sus actividades(Vergara, 2003:11)"

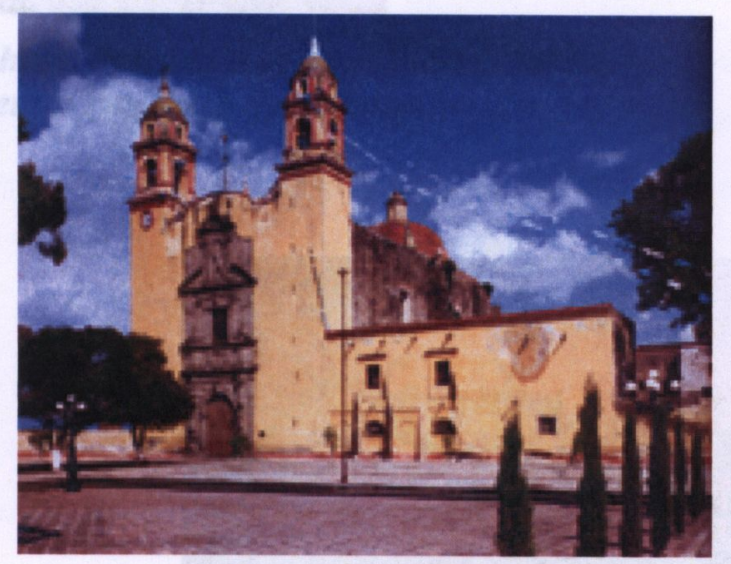

Parroquia de San Andrés, Fuente: Pág. Web de San Andrés

\footnotetext{
${ }^{18}$ Esta disposición espacial y elementos característicos comunes en la urbanidad de las ciudades hispanoamericanas, tuvo por objeto el ordenamiento no solo del territorio sino también de la conducta.
} 


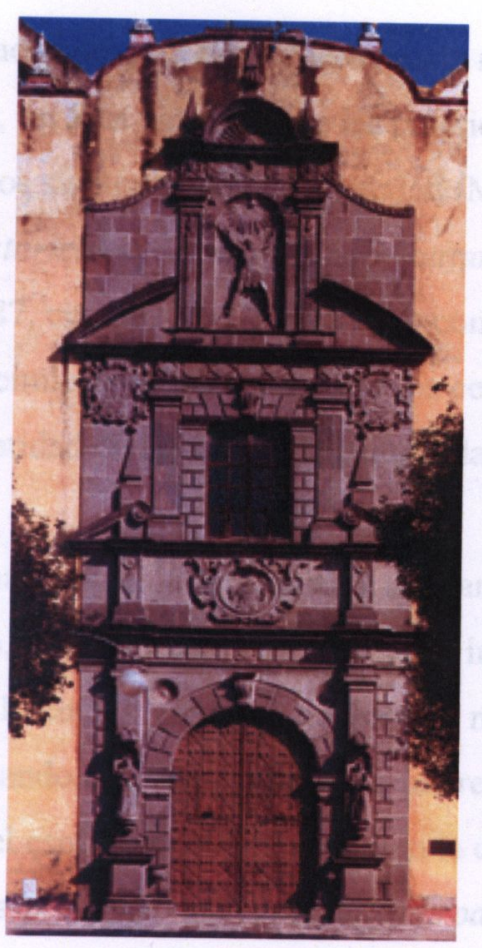

Fachada Parroquia de San Andrés, 2005

Fuente: Pag. web San Andrés

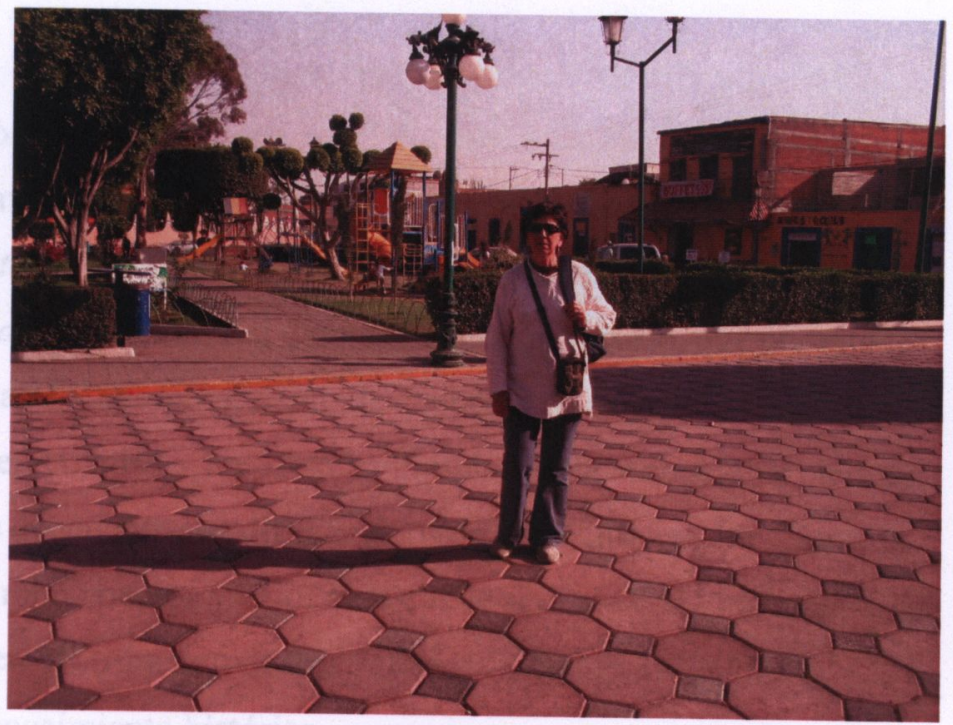

Zócalo

Este lugar es también el de la conmemoración cívica y comunitaria que refiere a los orígenes y a la unidad de la comunidad, en los rituales y prácticas cotidianas y en la construcción de la identidad (Vergara, 2003:9); permite la presencia de la diversidad social y cultural, aunque recientemente en competencia con otros que fomentan la segregación social, como las plazas comerciales(Ibid, 10). 
Varios autores lo definen como un lugar fuertemente marcado ${ }^{19}$ en el tejido urbano(Roland Barthes, cit. en Melé, 2006:18), un área valorada por las prácticas que en ella se realizan o en las representaciones que los sujetos tienen de la ciudad (Melé, 2006:19); "emisor de signos y símbolos que se nutren de la historicidad del marco, de la naturaleza de las construcciones, de las actividades (Levy, 1987, cit. en Melé, 2006:19), y con un contenido cargado de expectativas, de potencialidades y ofrecimientos reales. Estudiar los centros significa comprender los elementos constitutivos de la identidad de la ciudad: la centralidad y la historicidad(Ibid, 12)

Sin embargo, al igual que otros centros en Latinoamérica, está siendo cuestionado por la presión del crecimiento urbano, la dinámica de los mercados inmobiliarios y la fragmentación de las funciones centrales; a lo cual el gobierno contribuye mediante la renovación y refuncionalización de algunas áreas, apostando a la ventaja política que representa la visibilidad de acciones como estas, que revalorizan el espacio central y permiten la captación de nuevos recursos. Si consideramos que "El espacio urbano es(ha sido) producto de la actividad humana, de la suma de la estratificación de proyectos y de acciones, tanto individuales como colectivas(Melé, 2006:13)", el papel de la acción pública en la dinámica de los centros históricos es fundamental en la producción de la ciudad y se vuelve más eficaz sumado al legado histórico y a ciertas dinámicas económicas.

\subsubsection{El concepto de patrimonialización:}

En los discursos sobre el patrimonio histórico se introducen derechos subjetivos de los monumentos: "como conjunto de facultades otorgadas a individuos procedentes, por ejemplo, de las declaraciones de los derechos humanos" además del derecho natural intrínseco, que permite la institucionalización de políticas nacionales y del movimiento de cooperación internacional para su protección (Ibid., 78), que concreta su efectividad y funda su legitimidad en la atribución a ciertos edificios o zonas de la ciudad una serie de valores que difieren a los de uso e intercambio. La atención que se presta en México a los monumentos y sitios se basa, de acuerdo con Francoise Choay(Choay, cit. en Melé, 2006:86), en la atribución de tres valores:

- Didáctico: como soporte del conocimiento histórico.

- Estético: como objetos de goce universal

\footnotetext{
${ }^{19}$ Nota: En el sentido de Rolan Barthes, quien dijo que "la ciudad es un tejido formado, no por elementos idénticos, cuyas funciones pueden enumerarse, sino por elementos fuertes y por elementos neutrales, por elementos marcados y por elementos no marcados" (Barthes, Roland, 1985:264)
} 
- Nacionalista: como soportes del sentimiento nacional

A partir de lo anterior, Marc Laplante(Laplante, 1992, cit. en Melé 2006:86) propone llamar "patrimonialización" a este proceso de transformación del estatuto de un bien privado en público, que implica varias etapas: la selección inicial, la elevación a nivel de símbolo, la consagración y la exposición. Las tres primeras etapas dependen de los criterios definidos por las leyes y los organismos federales gestores; la exposición, como intervención(es) que apunta(n) a presentar al público el bien o lugar patrimonial, depende de acciones comunes entre los poderes locales y los organismos federales. En el caso de monumentos arqueológicos, como sería la pirámide, la exposición requiere para ser inteligible, de una importante intervención encaminada a reforzar el valor didáctico de dicho monumento. De esta manera,

Espacios, prácticas y bienes diversos van siendo retirados del flujo de la vida cotidiana, se reúnen, resignifican y recontextualizan y participan en la dinámica especifica de la dimensión de la cultura que crean y recrean los órganos públicos de conservación(Rosas, Mantecón, 2005:66)

Este proceso, también conocido como activación patrimonial(Ibid, 66), naturaliza el cambio y oculta el proceso de selección arbitraria. Si consideramos que esta activación es creadora de valor económico, simbólico y político y que a la vez constituye la memoria, identidad y territorialidad nacional, remite a cuestiones de hegemonía y derechos ciudadanos(Arantes, Antonio, cit en Ibid, 67) que habría que considerar al igual que las múltiples dimensiones que lo constituyen e interrelacionan, sobre las que se realiza la apropiación social. La constitución de este proceso permite visualizarlo como una lucha permanente para que sean incluidas las voces de todos, de los que han quedado fuera de este proceso, para extenderlo y actualizarlo, para que no solo el pasado forme parte de él, sino también el presente(García Canclini, 1987, cit. en Rosas Mantecón, 2005:67)

El proceso de patrimonialización es reforzado por la elaboración de discursos vinculados a la fundación de la nación y a la constitución de la identidad nacional, que son atravesados por organismos de cooperación internacional y fundamentan los procesos de transformación de bienes privados en bienes colectivos. En este sentido, la construcción de discursos exige sean cuestionados a partir de las desigualdades en su formación y en la apropiación del patrimonio, como cohesionador de una identidad nacional, distante del proceso de producción y circulación social y más bien habría que entenderlo y estudiarlo como espacio de enfrentamiento y negociación social y como recurso para producir las identidades y diferencias sociales(García Canclini, 1987,cit. en Rosas Mantecón, 2005:68) 
Otra problemática de este proceso es su insuficiencia, ya que a pesar de los discursos de los militantes, la política del patrimonio como ya dijimos antes, solo toma en consideración a los edificios y la imagen urbana. Las referencias a la noción de patrimonio de la humanidad y a la legislación del patrimonio intangible, constituido por el modo de relaciones sociales específicas de los barrios populares y de la vecindad, aparecen como un simple discurso periférico con respecto a la realidad de las acciones de protección al patrimonio(Melé,1998:25). La patrimonialización implica, que el único objeto de derecho continúa siendo el monumento, los usos solo se califican en función de su impacto sobre este y sobre la imagen urbana, de esta manera las restauraciones o rehabilitaciones suelen impulsar un cambio de uso de los edificios históricos teniendo como consecuencias que se adquieran nuevas cualidades y modifiquen las tradicionales relaciones sociales del lugar.

Como una consecuencia de este proceso, la proclamación de patrimonio de la humanidad a ciertos sitios históricos de diversas culturas, para la creación de una conciencia social y un marco regulador internacional para protección a los monumentos, ya no reposa más sobre la voluntad de los gobiernos o regímenes establecidos, sino que se constituye una nueva escala de normas a nivel local, nacional y mundial, adoptadas con el consenso de los estados que las ratifican y dan carácter de obligatorio: "Tal proceso refuerza la legitimidad de intervención federal en los centros, sacraliza los perímetros de las zonas protegidas, pero al mismo tiempo limita el carácter discrecional de las intervenciones al otorgar a un organismo internacional la capacidad de pronunciarse acerca de la coherencia de las políticas nacionales" (Melé, 1998:25). El conocimiento de estas normas, abre la posibilidad de su referencia en el marco de conflictos entre actores locales, permitiendo su acción y legitimación.

Otro giro que da el concepto de patrimonialización como efecto de su control por organismos internacionales, es que al realzar, de cara al exterior, la intensa producción material del pasado para acrecentar su prestigio y suscitar la admiración de extraños, se convierte en " $u n$ proceso de valoración económica, constituyéndose como un elemento más de los procesos globales de mercantilización y homogeneización cultural(Guerrero, Valdebenito, 2005) ${ }^{20}$." En este sentido, es importante hacer notar que una vez que se constituye el patrimonio en un territorio relativamente autónomo y extenso como resultado de transformaciones más amplias en el ámbito de la producción y circulación de bienes culturales, se modifica su uso y explotación, convirtiéndolo en un

${ }^{20}$ web.upla.cl/revistafaro/n2/02_guerrero.htm 
componente privilegiado de las demandas de consumo cultural. Una vez inserto en este mercado, como un efecto adicional, se desdibuja el valor simbólico que tiene para la identidad e integración de los grupos sociales(Canclini, cit. en Ibid, s/n).
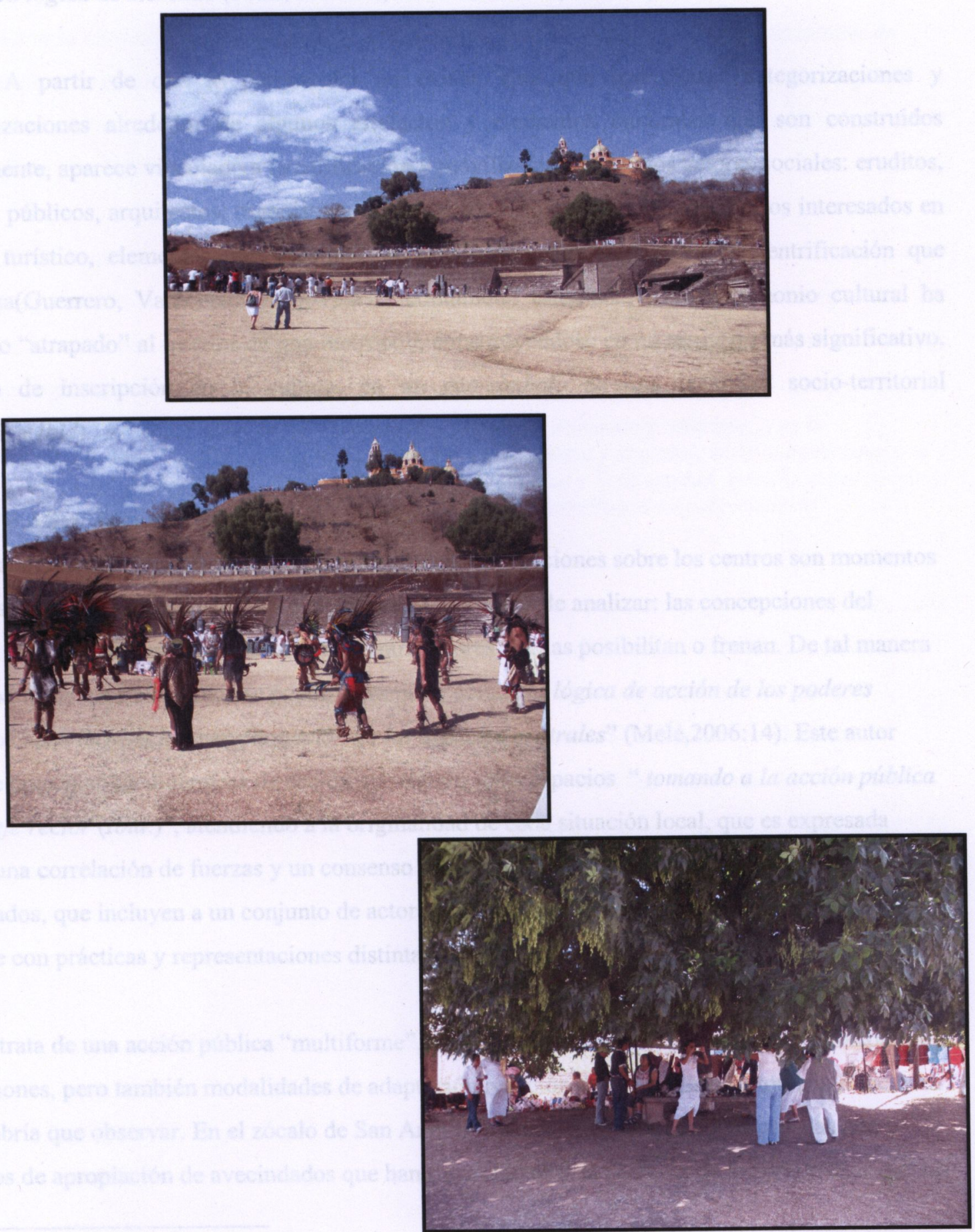

Festival Equinoccio de la Primavera, 2009 
Aunado a los procesos de globalización y masificación mundial, aparece la necesidad de reconocer un segundo proceso de construcción patrimonial: "La ecuación patrimonio-identidad nacional se ve desplazada en la actualidad por la de patrimonio-venta-consumo, guiada por unanueva lógica de mercado (Prats, 1997:s/n,cit. en Mantecón,2005:66)"

A partir de que lo patrimonial no existe, sino que son ciertas categorizaciones y jerarquizaciones alrededor de algunos artefactos y elementos culturales que son construidos socialmente, aparece vinculado a la calificación y movilización de ciertos actores sociales: eruditos, agentes públicos, arquitectos, organismos especializados, comisiones y empresarios interesados en el uso turístico, elementos que permiten su vinculación con el proceso de gentrificación que atraviesa(Guerrero, Valdebenito, 2005) a la comunidad estudiada, cuyo patrimonio cultural ha quedado "atrapado" al interior de una metrópoli, constituyéndose en un territorio más significativo, espacio de inscripción de la cultura, en un geo-simbolo ${ }^{21}$ de una identidad socio-territorial específica(Ibid).

\subsubsection{Acciones e intervención pública:}

De acuerdo con Melé, las operaciones de urbanismo y acciones sobre los centros son momentos donde se ponen de manifiesto varios elementos importantes de analizar: las concepciones del centro, las ideas de ciudades y las alianzas entre actores que las posibilitan o frenan. De tal manera que a partir de esos elementos se puede determinar cómo "la lógica de acción de los poderes públicos contribuye a la transformación de los espacios centrales" (Melé,2006:14). Este autor sugiere presentar las dinámicas de acción que siguen estos espacios " tomando a la acción pública como eje rector (Ibid.)", atendiendo a la originalidad de cada situación local, que es expresada como una correlación de fuerzas y un consenso basado en la gestión negociada de conflictos aparejados, que incluyen a un conjunto de actores para quienes el centro es un elemento clave, aunque con prácticas y representaciones distintas sobre este espacio.

Se trata de una acción pública "multiforme", refiriéndose con ello a que sigue ciertas razones e intenciones, pero también modalidades de adaptación/reacción de los distintos actores involucrados que habría que observar. En el zócalo de San Andrés, hemos registrado acciones pasadas como intentos de apropiación de avecindados que han fracasado ante la reacción de los originarios que las

${ }^{21}$ Un lugar, un itinerario, una extensión o un accidente geográfico que por razones politicas, religiosas o culturales revisten a los ojos de ciertos pueblos o grupos sociales una dimensión simbólica que alimenta y conforta su identidad(Bonnemaison, 1981:256, cit. en Giménez, 2000:29) 
impiden y se muestran como actores locales territorializados, con posiciones y reacciones de frente a los proyectos de los poderes públicos y en búsqueda de efectos que les beneficien: “ $\mathrm{Al}$ territorializarse la acción pública establece un nuevo consenso, distinto de las oposiciones sociales y políticas, y moviliza las cualidades especificas de los actores ligadas a su inscripción local, a su relación con la ciudad(Barel, 1985:133, cit. en Melé, 2006:15). Territorializar el patrimonio es destacar que este es expresión de una comunidad en particular, arraigado al suelo natal, ya que el territorio no es un espacio sobre el cual transcurre la vida social, el territorio es considerado "artífice" de esa realidad, históricamente construido y vivido.

El concepto de patrimonialización permite visualizar a un denso conjunto de elementos que lo integran, a una imbricación de actores que en él intervienen con diferentes capacidades e intereses, movilizados alrededor de objetivos diversos de acuerdo a las propias representaciones que cada uno construye, demostrando:

Que el patrimonio adquiere un lugar conflictivo, disputado y complejo.....en la conformación actual de las ciudades, tensionado entre lo local y lo global, entre lo tradicional y lo moderno, entre lo público y lo privado, entre la uniformidad y la diversidad, entre la sacralización y el desprecio, entre la inclusión y la exclusión, entre el desarrollo y el empobrecimiento cultural(Rosas, Mantecón, 2005:87)

Como se menciona en párrafos anteriores, la valoración y preservación del patrimonio, vista como una política conservacionista, de preservación, estudio y difusión, se deja en manos de eruditos, agentes públicos, arquitectos y organismos especializados, encontrando en las empresariales su inserción como actividad comercial. La necesidad de recrear una identidad colectiva en oposición a la creación de ganancias económicas, en la que el patrimonio es un bien intercambiable en un mercado, ocasiona situaciones de tensión y conflicto por la lucha en torno a su uso y apropiación. 


\section{ACTORES INVOLUCRADOS}

El espacio de análisis y las transformaciones que lo marcan actualmente está siendo intervenido por las acciones de diversos agentes de cambio, que presentan un espacio de interacción de grupos con actores y visiones diferentes actuando en el sentido de ocupar, vivir, apropiarse o en intentos de apropiarse de un territorio caracterizado por un fuerte crecimiento económico en la región evidente a través del proceso de urbanización acelerada del lugar. Su identificación estuvo dirigida mediante preguntas como: ¿quiénes están actuando como agentes de cambio en San Andrés?, ¿mediante qué acciones?, ¿desde qué lugares?, ¿qué intereses los movilizan? y ¿en qué momento lo hacen?. A través de recorridos, pláticas y entrevistas registradas en la comunidad, pudimos estructurar una guía que permitiera tener una visión lo más completa posible pero en una fase exploratoria todavía, de actores detonadores de los principales cambios en la cabecera municipal de San Andrés. De esta manera se construyeron las siguientes categorías:

\begin{tabular}{|l|}
\hline 1.Autoridades locales \\
\hline 2.Empresarios \\
\hline 3.Avecindados: \\
- $\quad$ Residentes enclaves \\
- $\quad$ Yuppies \\
- $\quad$ Hippies \\
\hline 4.Originarios: \\
- $\quad$ Autoridades comunitarias \\
- $\quad$ Familias clase media \\
- $\quad$ Promotores de desarrollo \\
\hline
\end{tabular}

\subsection{Autoridades locales.-}

Las acciones de gobierno de cara al exterior: búsqueda y logro de Indicadores y presencia en medios :

Las autoridades locales, desde administraciones anteriores, se han interesado en la búsqueda de indicadores que ubicaran al municipio en los primeros lugares de avance tecnológico, cumpliendo con el requisito de transparencia en la rendición de cuentas que se publican en la página web que lleva el nombre del municipio:

San Andrés Cholula fue una de las ciudades finalistas de la II Edición del Premio Latinoamericano de Ciudades Digitales, dentro de la categoría de ciudad grande. Este galardón se otorga dentro del VI Encuentro de Ciudades Digitales celebrado el pasado 1 de diciembre en la ciudad de Rio de Janeiro, Brasil. Este premio tiene como finalidad impulsar iniciativas de desarrollo y modernización de municipios latinoamericanos como una forma de incentivar el esfuerzo de los 
municipios que apuestan por la integración de los ciudadanos en el desarrollo municipal y su contribución a la minimización de la brecha digital por la utilización de las nuevas tecnologías, buscando que los beneficios de las Tecnologías de la Información y Comunicación se integren en la vida económica, social y cultural de las ciudades de Latinoamérica (www.puebla.mx.com) ${ }^{22}$

Esta página web, es compartida con muchos otros actores participantes en la conformación actual de San Andrés: empresariales que insertan información de promociones turísticas, compraventa y renta de bienes raíces, sitios y actividades de diversión, etc., estudiantes que la utilizan como espacio de sociabilidad, para promover proyectos o comentar noticias locales, denotando el interés de ambos grupos(autoridades municipales y empresariales), en mostrar y difundir el avance socio-económico y las cualidades del lugar a través de este medio, al igual que su esfuerzo por atraer visitantes y residentes que les permitan la obtención de beneficios económicos. $\mathrm{Al}$ mismo tiempo es sitio de oferta de empleos, denuncia de actos de corrupción y alteración del orden social y espacio en el que actores políticos ${ }^{23}$ opuestos al régimen panista actual, mantienen una permanente inserción de críticas y quejas a las acciones de los funcionarios locales.

El conjunto de modificaciones actuales de tipo urbano, espacial y de imagen que se observa, es apoyado por las autoridades municipales desde la administración anterior ${ }^{24}$ y visualizado como un proceso exitoso de "modernización" que lo lleva a ocupar en ese sentido, uno de los primeros lugares en el estado de Puebla, discurso basado en la presentación de un equilibrio entre "tradición/modernidad" que fue exhibido en anuncios espectaculares y en el internet, en la idea de mostrar avance urbano y tecnológico/conservación de historia y tradiciones. Actualmente "Todos somos San Andrés" lema que distingue a la administración en curso, es representado mediante los rostros de personas de culturas y estratos sociales distintos, interactuando o trabajando en equipo, lo cual se interpreta como la apertura o buena voluntad de un gobierno incluyente en la conformación de una "nueva" sociedad.

Recientemente el periódico La Jornada publicó los resultados del documento sobre Indicadores de Desarrollo Humano ${ }^{25}$ y Género del Programa de las Naciones Unidas para el Desarrollo(PNUD)

\footnotetext{
${ }^{22}$ Fuente: www.puebla.mx.com

${ }^{23}$ A través de periódicos virtuales como el Milenio y e-consulta, los grupos priistas que controlan los gobiernos municipales de San Pedro Cholula y Puebla, mantienen en la mira y tratan de controlar las acciones del actual gobiernos panista de San Andrés, con el afán de recuperar el poder que desde 1994 ocupa este partido político.

${ }^{24}$ Nos referimos a la administración: 2006-2009

${ }^{25}$ Definiendo al Desarrollo Humano como la ampliación de la libertad de los individuos para que puedan decidir lo que quieran ser o hacer entre una gama de oportunidades reales.
} 
en México, 2000-2005, calificando tres condiciones sobre el ejercicio de la libertad del individuo sobre su propia vida: la posibilidad de tener una vida larga y saludable, la adquisición de conocimientos individual y socialmente valiosos y la oportunidad de obtener los recursos necesarios para disfrutar de un nivel de vida digno, calificando a la capital del estado y al municipio de San Andrés, con el más alto índice de desarrollo humano en el estado, aunque aún a veintitrés lugares del Distrito Federal ${ }^{26}$. Los datos en Internet reportados por Milenio, en $2008^{27}$, informan que San Andrés es el $8^{\circ}$ municipio más poblado de Puebla, con un potencial de desarrollo de $6.5 \%$, superior al promedio estatal y nacional( $1.2 \%$ y $1.0 \%$ ) y un crecimiento mayor en el sector inmobiliario.

En opinión de los funcionarios locales, las consecuencias de la extensión de la metrópoli se aprecian como problemas para el municipio debido entre otras cosas, a la falta de reglamentos de desarrollo e imagen urbana que regulen su expansión. Específicamente ubican este problema en el área que hemos llamado de diversión y entretenimiento para avecindados y visitantes que colinda con la Universidad de las Américas y que aún forma parte del centro histórico, actualmente invadida por publicidad de los negocios ahí establecidos, temiendo que suceda lo mismo en el área de la pirámide. Ambos espacios, por efecto de la reciente remodelación resultan más atractivos al exterior, provocando algo que les preocupa “que todo mundo se quiera venir a San Andrés a poner bares"

No claro, esto de la conurbación aunque no se quiera y como tampoco hay un reglamento de lo que es construcción de lo que es todo esto, entonces también eso no permite tener esa modernización no? No permite también tener un crecimiento regulado al no haber reglamentos no? Eso es lo que está pasando y también interés de ciertas autoridades que cada administración sus enfoques son distintos, entonces si les interesa lo moderno pero a esta administración le interesa estas cuestiones del arraigo, de la identidad, del mundo de las tradiciones con una serie de proyectos culturales no? O en favor de la conservación del patrimonio cultural"(Mujer, 37 años, profesionista, originaria)

La formulación de quejas y denuncias ciudadanas contra el ayuntamiento por actos de corrupción y problemas con la vigilancia en la zona de bares donde se presentan conflictos frecuentes que afectan principalmente a los vecinos de ese perímetro, también encuentran un espacio en la página web. Las autoridades en principio opinan que es un problema que los vecinos de esa zona generaron al rentarles espacios y que ahora ellos mismos deben resolver:

Porque hay gente que vive ahí cerca de la 14, que yo conozco y sí, o sea, están molestos. Molestos porque dicen es que pasa cada cosa que sí violaciones que sí...entonces a veces mejor ni te metes, mejor cierras tu puerta, o ... ¿qué haces?.... O llamas a la patrulla y punto.... ¿ qué más?"

\footnotetext{
${ }^{26}$ La Jornada de Oriente, Puebla pasó del lugar 24 al 23 en el índice de desarrollo humano según el PNUD, viernes 24 de abril de 2009

${ }^{27}$ www.milenio.com
} 
En otras ocasiones ante estos mismos problemas su respuesta hacia la propuesta de algunos vecinos para el cierre de antros, es una negativa rotunda que antepone el cumplimiento del pago de obligaciones fiscales de estos negocios que les otorga el derecho de permanecer y seguir operando en la zona, a las demandas de vecinos por escándalos y problemas de alteración del orden, por muy graves que estos sean, suscitados en la zona.

Una de sus principales preocupaciones gira alrededor de la difusión cultural y turística del "acervo" cultural y patrimonial por medio de la organización de festivales y muestras artísticas o del folklore mexicano, haciendo un uso más frecuente de los espacios públicos como el zócalo de San Andrés, el de la plazuela en Tonantzintla y el área de la pirámide, como el recientemente organizado Primer Festival de Equinoccio de la Primavera. Se recurre a las exhibiciones fotográficas y plásticas como forma de atraer y "educar" a la gente, que a la vez funciones como una estrategia que mantenga el espacio del zócalo activo, atraiga al turismo y mantenga "vacío" de vendimia este espacio. Es decir, el espacio central de San Andrés ahora está apropiado por el municipio quien lo utiliza como escenario artístico, por otra parte denota una exclusividad de uso para sus fines, una acción de empoderamiento que se empeña en hacer notar a la comunidad, a quien solo se le permite ocuparlo durante la celebración de las festividades religiosas más importantes:

En lo que es cuestión cultural pues nuestro propósito es promover, difundir, a través de concursos, convocatorias, y todo lo que se pueda, lo que son las tradiciones ¿no? Apoyos institucionales, eventos artisticos, ..tenemos también la propuesta de promover lo que es el apoyo a la investigación, sobre todo por lo del centenario y bicentenario, hay la propuesta también de algunos artículos de publicación, de conciertos, este..., foros, de difusión educativa $a_{i}$ no? De hacer parte a los jóvenes de la problemática social, tomarlos en cuenta ¿no?, talleres de prevención, drogas, lo que es todo, de sexualidad también, algunos talleres de escuela para padres. 


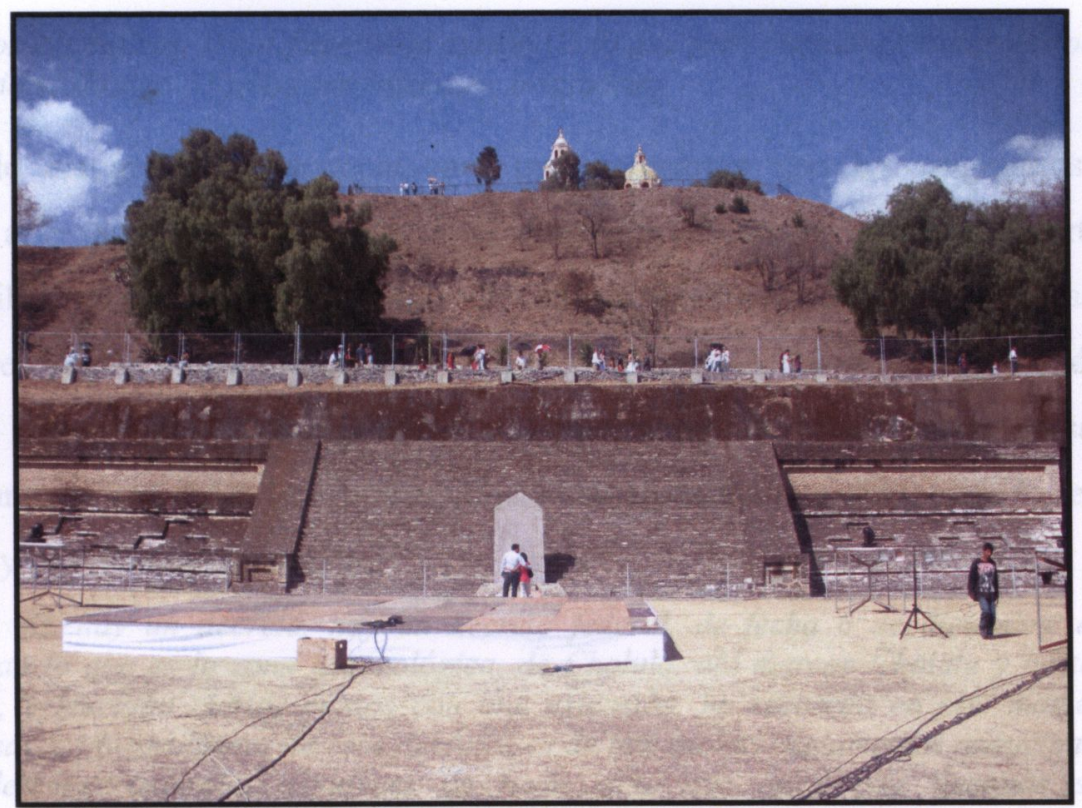

Festival del Equinoccio de Primavera 2009

Derivado del interés por la difusión cultural, tienen en puerta varios proyectos turísticos en espera de aprobación, como el de un corredor turístico que atravesaría seis calles del centro histórico y que comunicaría a éste con la zona de la pirámide:

Ahorita se está pensando posiblemente poner un corredor turístico de la pirámide para acá... ¿Vé que hay una calzadita, acá atrás? Esa calle sería y tiene que llegar acá. Esperemos que se lleve a cabo ese proyecto....el municipio tiene algunos proyectos también respecto a la zona arqueológica, hay varios proyectos pero dependen de que sean aprobados.....(Mujer, 37 años, profesionista, originaria)

En cuanto a sus relaciones interinstitucionales se quejan de la falta de apoyo e información institucional del INAH en la zona patrimonial, es decir, de los reglamentos formulados que les permitan a ellos, el conocimiento de restricciones y permisividad: "la misma INAH ni conoce la estructura ni conoce las tradiciones de la región ¿no?. De igual manera se quejan de las instituciones de educación superior ubicadas en el área municipal de quienes solo reciben ofrecimientos no convenios que garanticen becas a jóvenes sanandreseños, o colaboración en proyectos que impulsen el desarrollo comunitario, como retribución a los beneficios que reciben por su permanencia en la comunidad, lamentando especialmente la relación complicada con la Universidad de las Américas desde administraciones anteriores:

¿porqué esta separación entre San Andrés y la Universidad, si estamos dentro del municipio, cómo es posible que no nos sintamos parte?. Es un gran problema de la Institución porque no sabe dónde está parada, entonces hace programas pero no en beneficio de la comunidad, de su gente y les vamos a apoyar. Entonces yo creo que primero es conocer dónde estoy parado, quiénes son, cómo funciona y en base a eso ahora si plasmo proyectos que puedan ser útiles a la comunidad..Desde la diversidad podria hacer infinidad de cosas $;$ no?, desde rescate del patrimonio, 
fomentos educativos, igual fomento al turismo a lo que sean cuestiones culturales podría apoyar la universidad.(Mujer, 37 años, profesionista, originaria)

Una de las grandes preocupaciones que comparten con los originarios, es sobre la protección de arte sacro en sus templos y es alrededor de este problema que participan en una asociación civil conocida como Pro-defensa de Cholula. En cuanto a la pirámide, también esperan que se formulen reglamentos municipales como complemento del de INAH, donde se expresen claramente los límites de las zona, usos de suelo, lineamientos de construcción y desarrollo urbano, etc..A la pregunta acerca de si San Andrés cuenta con algún decreto oficial que lo reconozca como zona histórica y patrimonial, respondió:

Si, hay un decreto, hay un decreto federal, de fecha 6 de diciembre de 1993, donde delimitan lo que es la zona arqueológica, de Cholula, ahí marcan Cholula y parte de eso es San Andrés, y manejan ciertos puntos con una extensión, no recuerdo en este momento de cuántas hectáreas.... El problema de esos decretos es de que no hay reglamentos municipales para apoyar esos decretos federales. Entonces de nada sirve que haya esos decretos si no hay una reglamentación municipal que sirva para la protección de ese patrimonio(Mujer, 37 años, profesionista, originaria)

En cuanto a la denominación de "centro histórico", solo existe una propuesta para la formulación de un reglamento pendiente de ser aprobada por el INAH. Sin embargo han contratado los servicios de una empresa para que integre todo un expediente, un inventario de monumentos y una publicación, de manera conjunta con San Pedro Cholula, para buscar la declaratoria patrimonial de ambos municipios ${ }^{28}$ y juntas auxiliares, que próximamente quedará concluida:

No, hay aprobado, no hay, también se está trabajando, se contrató a una empresa para la elaboración de... que se busque toda la documentación necesaria para que se busque la declaratoria de patrimonio pero no nomás de la cabecera, sino del municipio, se está trabajando de manera conjunta con San Pedro Cholula, eh... yo espero que a mas tardar en unos tres meses quede concluida toda esta papelería junto con un libro, viene el catálogo de monumentos, viene el reglamento o sea si no funciona el del INAH, puede funcionar este, porque es un trabajo entre los dos municipios que se está haciendo una investigación.."

Los esfuerzos realizados en cuanto a la renovación de edificios, a la formulación de un reglamento interno que regule a ambos municipios para la obtención de la declaratoria patrimonial de "centros históricos", van más en dirección de armar una estrategia con fines turísticos que al paso del tiempo se convierta en un recurso económico que "salve" a la región:

Yo lo vería como más en beneficio, porque de todas maneras la cultura tiende a cambiar, y va incorporando siempre elementos en la socialización, las formas tradicionales en las comunidades, siempre van modificándose, y lo estamos viendo también con el proceso de urbanización en San Andrés, en San Pedro, entonces si va cambiando. Pero si con esto logramos, detener el deterioro de ese patrimonio, que además en un futuro se supone que Cholula puede ser, una de sus actividades económicas puede ser el turismo, si no lo defendemos, si no lo cuidamos y si

\footnotetext{
${ }^{28}$ Se busca el reconocimiento como "región", incluyendo a todas sus juntas auxiliares que también quedarían sujetas a las reglamentaciones que se formulen.
} 
no lo reglamentamos después ¿qué ofreces?... anteriormente San Andrés estaba dedicado a lo que era la agricultura y la ganadería y hoy ¿qué hay? Entonces son...no sé....porque ve que ha venido cambiando su vida cotidiana, entonces quieran o no son procesos.... Entonces $s_{\zeta}$ uno más?

...digo......Y además con beneficios ... yo lo veo como un beneficio...(Mujer de 37 años, profesionista, originaria)

Desde hace cinco administraciones el partido oficial en este municipio es el Partido Acción Nacional y existe el rumor de que en los periodos electorales la población se divide en cuanto a preferencias de voto, en las mismas categorías básicas de este estudio, apoyando los avecindados el regreso de los candidatos representantes del Partido Revolucionario Institucional.

\subsection{Los empresarios.-}

Los empresarios como el de "Container City", se presentan como inversionistas creativos, interesados en proyectos turísticos detonadores de productividad. Quieren construir "ciudades vivas", hacer que el turista "regrese", atraer a "cierto tipo" de gente que como ellos disfrute, quiera experimentar y se enamore de su concepto. Son conceptos importados de países primermundistas con modelos y estructuras socioeconómicas muy distintas a las de este lugar y tienen la opinión de ser los únicos realmente interesados en detonar la economía local mediante proyectos de este tipo. Su relación con las autoridades la definen como "problemática" porque obstaculiza sus acciones, exige cuotas, pero no es capaz de hacer lo que ellos hacen.

Considero importante que en todas las zonas como Cholula, el turista viene y se va, pero es importante hacerlo que regrese. Entonces cada pais, en España y otros, está empeñado en lograr eso... hacer que el turista regrese, hacer ciudades muy vivas;"

Sin embargo.....Pelear con el Ayuntamiento, que complica, obstaculiza, cobra, no apoya ... pero somos el único punto que está desarrollando el turismo...(Hombre, 36 años, profesionista, avecindado)

Crean espacios al interior de la comuridad, dirigidos a gente con alto poder adquisitivo cobrando la originalidad de sus conceptos, que en este caso lo representa el estar en un escenario natural y patrimonial como este. Se alojan en el imaginario social de gente joven, clase media y media alta, que como ellos valore este modelo, con un concepto ecológico, que fusiona elementos de diversas culturas con la originalidad de ofrecer la experiencia de sentirse en sitios como Nueva York, Holanda, Inglaterra y al mismo tiempo "estar" en el centro de otro de gran valor cultural como lo es el espacio ancestral, prehispánico, con características esotéricas, sitio mágico y mítico como la pirámide de Cholula. Se enfrentan a algunos problemas cuya solución está en manos de las instituciones, por lo que buscan y mantienen vínculos empresariales y políticos con el gobierno estatal en los cuales apoyarse para la solución de problemas en sus proyectos productivos. Trasladan algunas de las fallas de ellos, a las autoridades municipales para justificar el incumplimiento de ciertos servicios a sus clientes, esperando que aquellas las resuelvan. 


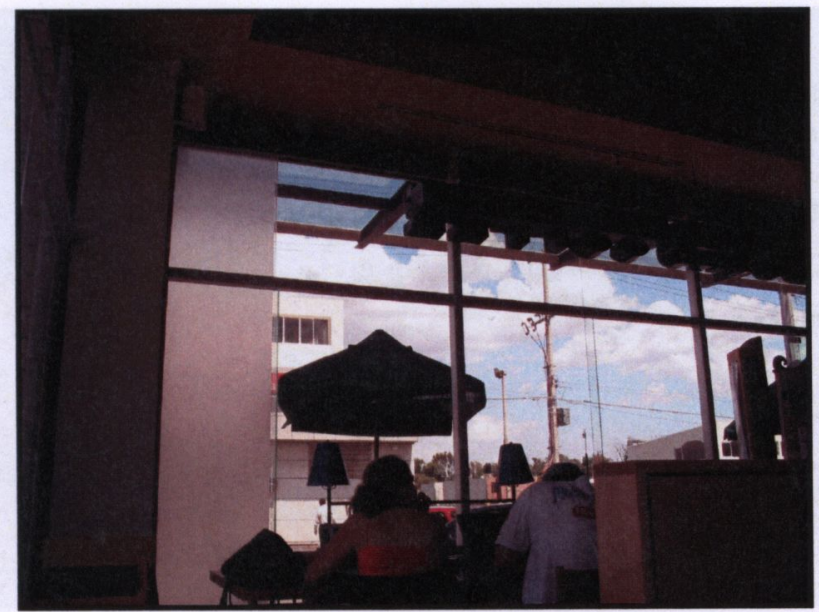

Starbucks Coffee, 2009

Nos pareció importante conocer sus planes y acciones emprendedoras a futuro por ser un lugar experimental que se inserta calladamente en la comunidad que ha resultado exitoso en cuanto a la originalidad del concepto y los altos costos que sus arrendatarios están dispuestos a pagar:

También vienen del DF y del extranjero. Y ya nos están copiando la idea, sí, acá a la vuelta ya van a poner otro, allá por CU en Puebla, ya pusieron unos cuatro trailers......(Empresario, hombre de 38 años, avecindado)

Y sobre sus planes a futuro: avecindado)

Estructurar el container para "clonar" por otros lados(Empresario, hombre de 38 años

En otro terreno, a dos cuadras de este lugar, instalan ya otro Container City que intenta colocar setenta estructuras, de uso habitacional y comercial dirigido a estudiantes, que en este momento se mantiene "oculto" con grandes mantas durante el proceso de construcción en el que todavía se encuentra. Los planes de implantación acelerada de este proyecto, se han detenido manteniéndose diez o doce estructuras únicamente con las mantas promocionales. 


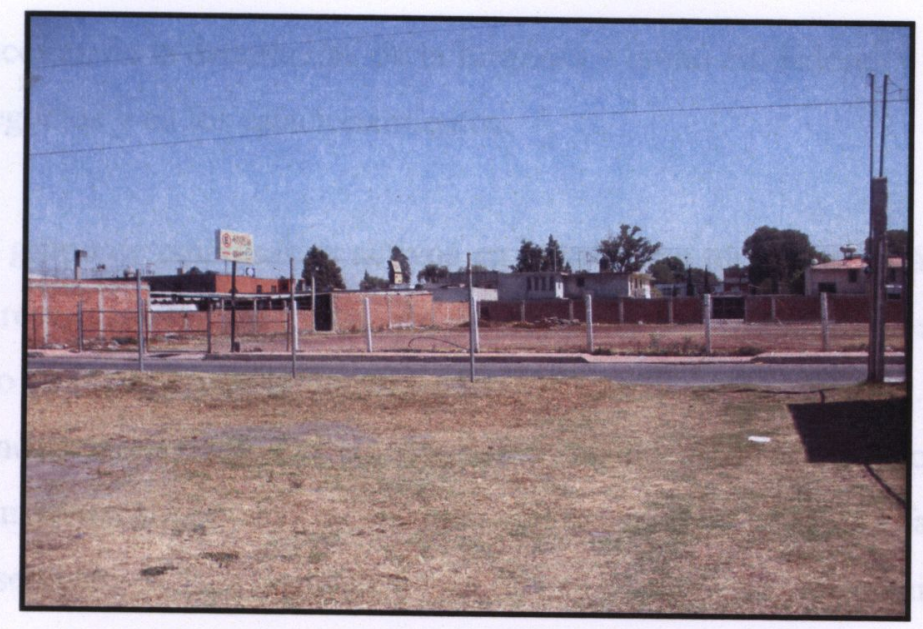

Lotes destinados a estacionamientos, calle 12 Ote.

Se rumora que personajes políticos estatales, participan como socios de algunos negocios en la zona de bares y discotheques, integrando un grupo corporativo que desde hace muchos años han controlado el área, participando con la imposición o revocación de reglamentos que de acuerdo al momento, se conviertan en medidas que apoyen la obtención de ganancias y control de esta zona. Estas acciones los convierten en actores importantes de cambios por intervenir con capital político, social y económico que se ha extendido ahora en este lugar con inversiones en otras áreas como la de la construcción, la turística y el narcotráfico.

Otro fenómeno detonador de cambios en el lugar perteneciente a este grupo empresarial y vinculado a los intereses de la globalización que se ha insertado con gran aceptación de los avecindados en la zona, es el establecimiento de franquicias internacionales destacando entre otras Mc Donalds, Burguer King, Starbuck's Coffee, Sushi Itto, Pitza-Hut, y otras nacionales como Café Punta del Cielo, Tartlets, Oxxo, Italian Coffee, etc.. La vinculación de esta zona con la financiera en una de las plazas comerciales más cercanas a la cabecera municipal en la que ofrecen servicios bancarios las instituciones más conocidas en el país, ha sido exitosa y denota la conformación estructurada de la oferta de servicios que ha penetrado en la zona creando o respondiendo a una creciente demanda a la que se desea atender y extender.

Es importante mencionar que los negocios de los cuales son propietarios este grupo, como lo hemos citado en otra parte de este trabajo, no son fuente de empleo para los sanandreseños, que en muchos casos ni los conocen. Las oportunidades de trabajo que se les ofrecen o en las que ellos se insertan es informal, de muy bajo nivel y como otra opción está el autoempleo, ocupándose en la 
industria de la construcción, de la decoración, de la limpieza o como cuidadores y acomodadores de carros afuera de los negocios y en los estacionamientos.

En general, el grupo de empresarios activos en la cabecera municipal están vinculados a la industria hotelera y restaurantera, de bares, de la construcción, inmobiliarias, del turismo y transporte, apareciendo en la página de internet que lleva el nombre del municipio. Es en el ramo de la construcción en donde aparecen algunas constructoras establecidas en la cabecera municipal, el resto son actores que invierten sin residir en esta área, con excepción de algunas familias que si son residentes y se van insertando en la compra-venta de bienes raíces y/o en el inquilinato, como una reinversión e incremento del patrimonio familiar. Cabría insertar en este grupo como actores que intervienen en el proceso de transformación del municipio, a algunos terratenientes originarios que mediante la compra-venta de terrenos han logrado convertirse en empresarios en la zona y los que se dedican a la venta de pipas de agua en Puebla y en la localidad de los cuales hablaremos al final de este apartado en donde aparecerán incluídos como originarios impulsores del desarrollo.

\subsection{Los Avecindados.-}

Residentes de "enclaves":

Generalmente son de clase media alta, profesionistas, ejecutivos o empresarios que llegan a vivir en condiciones económicas privilegiadas, o en una economía ascendente, eligiendo para vivir terrenos extensos, donde construyen hábitats confortables y sobre todo seguros. Los conjuntos "cerrados" y espacio con cinco o diez familias, en la modalidad de condominios y son otra opción para familias clase media generalmente con niños pequeños que usan el área común, como un espacio público(parque) para socializar adentro de estos espacios con las otras familias que habitan en estos conjuntos. La zona en la que se instalan es la del centro, próxima a las familias sanandreseñas.

Tienen en común su interés por el arraigo histórico del lugar, el orden socio espacial, armónico con la naturaleza y el ambiente tranquilo. Generalmente se mantienen ajenos a la vida local, aunque reconocen la "urbanidad" de su gente porque acostumbra saludar, con quienes mantienen relaciones efímeras, bien ubicadas, como "el señor de la tiendita", "la de las tortillas" o "el que vende elotes", etc.. Atraviesan el municipio únicamente en automóvil, el cual les resulta indispensable por realizar la mayoría de sus actividades en la metrópoli hacia donde realizan recorridos diarios. En su condición de avecindados perciben cierto temor hacia la comunidad, 
resultando esencial en su percepción del entorno, los servicios de seguridad a los que han estado acostumbrados en las grandes ciudades.

Otra cosa que me desconcertó fue que yo siempre adondequiera que he vivido siempre ha sido con vigilancia, entonces el darme cuenta de que ahora nuestra casa daba a la calle, no... me pasé 15 días sin dormir, te lo juro, hasta que mis hijos me dijeron: mamá ¿que no te das cuenta que asi vive todo el mundo? Y pues si....., ahora lo veo asi(Mujer, 57 años, ama de casa, avecindada).

Sus expectativas lejanas a la de la vida comunitaria, como en otros sitios similares, dificulta su vida cotidiana en el lugar, se quejan del ruido al que califican de "contaminante", refiriéndose a la quema de cuetes y la música "estruendosa" de las fiestas del cierre de calles, la quema de basura, las moscas y malos olores que despiden las pequeñas granjas de subsistencia familiar de los originarios que mantienen como parte de su estilo de vida:

¿Cómo me siento? Bien pero lo que no me gustó y que no me imaginaba era la contaminación del ruido. Porque aqui todo el año los cuetes, a veces es durante toda la noche; y son unos cuetones; que no te dejan dormir, o bien, te despiertan pero sobre saltado, ... es horrible. Después, ya ves que estamos enfrente del balneario, bueno, pues toda la mañana ponen la música a todo volumen y qué música y yo digo ... ¿ pues que no pueden escucharla bajito?, ¿ Porqué tiene que ser tan alto?;(Mujer de 57 años, ama de casa, avecindada)

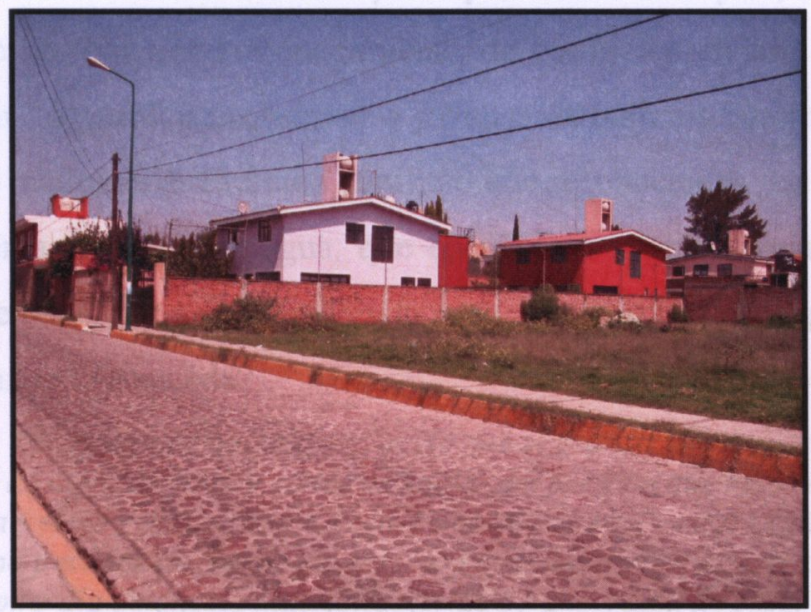

Casas avecindados

Generalmente consiguen "buenos precios" al comprar su(s) terreno(s) lo cual les anima en muchos casos a adquirir más, ya que siempre aparecen buenas oportunidades que aprovechan para construir y vender o rentar. Vivir al interior del área del centro histórico y cerca de la pirámide, lo encuentran como un "plus" para su propiedad y consideran que en unos años más, no más de diez quizá, los problemas del ruido que por ahora les aquejan se corregirán, porque los vecinos terminarán por aceptar su presencia y reconocer lo perjudicial que resulta mantener estas prácticas y la importancia de una buena relación con este grupo: 
Una amiga me decía una cosa: esto dentro de unos años va a ser como Coyoacán, que se fue transformando poco a poco hasta que llegó a ser y es de hecho una de las zonas más caras del DF(Mujer, 57 años, ama de casa, avecindada)

Consideran que lo único que se necesita es hacer consciente a la gente de lo dañino que son algunas de sus prácticas, hablar con ellos informándoles de qué pasaría si no dejan de hacerlo. Por ejemplo la basura, que no se debe quemar ni tirar en la calle. En este sentido se percibe una gran confianza para presentarse ante las autoridades municipales o civiles, a quienes consideran ilógicas o incapaces en la solución eficaz de problemas y encuentran factible el interceptarlas en cualquier momento o lugar, para realizar el reclamo o demanda exigiendo su solución inmediata.

Pero tengo ganas de ir a hablar con el presidente y decirle que ponga ese servicio otra vez, o con la directora de la escuela y decirle que ponga carteles o bien yo los hago, les llevo bolsas de basura o yo que se, pero definitivamente hay que trabajar con los adultos(Mujer de 57 años, ama de casa, avecindada)

En cuanto al incremento de bares en la 14 oriente, que se va acercando a la zona residencial en donde han ubicado su residencia, lo consideran y califican de malo y dañino para la comunidad y los jóvenes. Responsabilizan únicamente a las familias originarias que rentan sus terrenos para esos usos, junto con las autoridades municipales y estatales corruptas, están contribuyendo al deterioro social del entorno. No tienen conocimiento de conflictos en ese sentido y reconocen que sigue siendo un lugar "seguro" por observar a jóvenes extranjeros caminando tranquilamente durante la media noche o madrugada. El único conflicto que reconocen es por el negocio de los originarios en cuanto a la venta de pipas de agua, que encuentran también pernicioso por la posible escasez y agotamiento de los mantos acuíferos en la región, preguntándose ¿qué va a pasar con la gente de la comunidad cuando eso suceda?

Si, se supone que alguien quiso que se parara la venta de agua pensando en cuidar los mantos de agua de aquí, y entonces había una persona que ni te sé decir quién sea que vendía pipas de agua y llegó esta persona a decirle que ya dejara de estar explotando, que el agua era para este lugar, no para los de fuera, que si no lo hacía iba a ver que se le clausurara el pozo, ... me parece que al otro día amaneció muerto(Mujer de 57 años, ama de casa, avecindada)

Lo que más desean es que se convierta en un lugar más ordenado, limpio y que se legisle y hagan respetar los derechos de todos, convertir a San Andrés en un lugar más agradable para vivir.

A mi me gustaria que siguiera conservando el sabor así como de pueblo, pero que la gente tenga mejores condiciones de vida, en sus casas, que ojalá se hagan campañas de educación, de concientización, al interior de sus vidas, porque se traduce al exterior y se vuelve en una comunidad más agradable para vivir(Mujer de 57 años, ama de casa, avecindada)

Lo que está en juego es el control del lugar y sus usos, acostumbrados en otros contextos a dirimir todas sus diferencias por medio de la legislación, reglamentaciones y códigos de ética, o medioambientales, cuentan con un recurso en relación al conocimiento de la negociación y el 
reclamo de derechos ante las autoridades a quienes interpelan confiadamente. Según refieren ellos mismos, nunca les han solicitado cooperaciones para las festividades, lo que denota el desánimo de los vecinos que seguramente enfrentaron muchas negativas, o la ausencia frecuente de estas familias que pasan largos periodos fuera de sus casas.

Su importancia como actores económicos que influyen en el lugar, radica en su frecuente inserción al mercado de bienes raíces y al inquilinato o como promotores habitacionales en la zona, ya que su presencia en el lugar es guiada en términos de plusvalía y ganancias, como actores sociales, que pasan por alto las relaciones sociales que conforman al lugar, mantienen la distancia social y como actores políticos, que hacen uso de la ley en situaciones de conflicto vecinal o con las autoridades facilitando la organización y la construcción de una identidad vecinal situacional, útil para la solución de problemas vinculados al control del espacio.

Los yuppies.-

Con una edad que oscila entre 28 y 35 años, algunos de ellos son hijos de funcionarios o ex funcionarios públicos de alto nivel en la metrópoli que generalmente residen en Puebla y son propietarios de algunos antros, o hacen uso de las áreas de consumo ubicadas en la zona de franquicias, otros son egresados de la Universidad de las Américas que debutan como jóvenes empresarios guiados por otros expertos en las áreas de diversión y gastronomía, invirtiendo recursos familiares en el incremento del patrimonio o en la construcción de uno propio. Además de estar interesados en hacer inversiones exitosas, gustan de ambientes más relajados y con más apertura como el de San Andrés :

Tenemos a mucha gente de fuera: de Veracrúz, Oaxaca, del DF y también vienen de Puebla. Lo chido de este pueblo es que se conserva asi, uno encuentra todaví, caballo, perros, muchos perros y tienes la diversión y ofreces algo atractivo como esto(Hombre, 28 años, profesionistas, a vecindado)... Yo odio la ciudad, rehúllo a lo urbano, solo vamos a visitar a la suegra... Son más "borregueados".... Además estamos en una "ciudad" que se está renovando constantemente, unos vienen y se van y luego llegan otros, además algunos se quedan, efectivamente, si encuentran oportunidades como ésta y siempre va a ser así, además de que hay bastante dinero;

Eligen para vivir la zona más próxima o cercana a la universidad, como es la Recta PueblaCholula, Camino Real a Cholula, algunos de ellos en los edificios de departamentos con servicios integrados, se desplazan en motos o bicicletas de modelos recientes, conviven tanto en los espacios al interior de la Universidad como en algunos de los restaurantes, cafés y bares ubicados en el área más próxima a esta institución. Se les puede ubicar también en los espacios de franquicias situados en el cruce con la vía rápida a Puebla y nunca en el zócalo y calles que lo circundan, o en el área de la pirámide, lugares de uso cotidiano para la gente de la comunidad y turistas. 
El espacio de reciente creación: Container City es bastante frecuentado por este grupo y por gente similar que se traslada desde Puebla, como los hijos del actual gobernador, especialmente en el horario nocturno cuando calles y estacionamientos se llenan de vehículos de modelos recientes, de marcas reconocidas que alcanzan precios muy altos. Los propietarios de bares o restaurantesbares, los atienden directamente y son apoyados y frecuentado por grupos de amigos. Prefieren contratar a gente de Puebla para preparar alimentos y atención a los clientes y como ya dijimos, los servicios que algún sanandreseño realice, es como vigilante, valet parking, viene viene o en la limpieza.

Gustan de un estilo creativo para decorar sus negocios, recurriendo a gustos cosmopolitas en la decoración y la música, y en la preparación de una amplia variedad de alimentos que muchas veces fusionan con la local que ofrecen en sus negocios. El nombre de los espacios también está vinculado a sitios lejanos o son fusionados con los locales como en este caso "siete santos" representados en la decoración de estilo contemporáneo que aparece en los muros de este bar:

No, yo alguna vez lei que era una leyenda de Escandinavia o algo asi: 7 ascetas que deciden renunciar a sus bienes y se retiran a una cueva donde permanecen mucho tiempo..... después de 300 años los encuentran con vida, causando asombro y en ese momento mueren;

En cuanto a la música que se escucha:

Pues ponemos tranquila como ahorita, también ponemos "techno" $y$ "beat", aqui lo fuerte es la "techno". Pero procuramos no ponerla durante mucho tiempo porque la gente se espanta y se va... se harta... Depende del "mood" del día(dice ella)...Ahora los miércoles van a ser de "funk" $y$ las damas van a ser gratis... Vamos a promoverlo.(pareja de jóvenes de 26/28 años, profesionistas, avecindados)

Su comportamiento es bastante desinhibido y durante sus encuentros en grupo hablan de sus viajes, evocando ciudades primermundistas y sus visitas a las playas de moda, esto deriva en la imposición de gustos y estilos que enseguida son adoptados por sus seguidores. En general se mantienen bastante ajenos a lo que sucede en la comunidad, percibiéndolo como un mundo "folklórico" inusual, que no les interesa entender pero que le da un toque especial al de ellos. No se quejan de mal trato de la gente de la comunidad, al contrario, encuentran apoyos como las condiciones de renta, la permisividad y servicios. 
Los hippies.-

Llegan atraídos por la tranquilidad del lugar, que en comparación a la ciudad es más relajado, cercano a la naturaleza y les permite disfrutar del ambiente juvenil y más permisivo que se ha creado en San Andrés. El escenario natural es más valorado por ellos sin dejar a un lado las rentas mucho más baratas que en la metrópoli, en espacios que no ofrecen comodidades y a veces en estado de abandono. Pero es importante mencionar que desde los años sesenta, a partir de la instalación de la UDLA, Cholula resultó atractiva para estos grupos, un informante recuerda el "hippismo" de ésa época en San Andrés:

De aqui desde San Pedro hasta la entrada de la UDLA, y acá, principalmente los que estudiaban pintura, y los de antropología que eran los más extravagantes, aqui alquilaban una casita de adobe, y principalmente si era de adobe y piso de tierra era mejor, se compraban un petate, petate, fue el hippismo en esa época, un derroche de dinero, mientras más gruesos fueran los huaraches, mejor, ...traían sus pantalones de mezclilla, de esos como overol, unos anteojitos tipo este...Beatles, de esos chiquitos, pero andaban superestrafalarios, pero eran los que dejaban mucha lana. Alquilaban casas y pues a la gente lo que querían era sacar dinero, lo que les pedían daban, y la gente aqui muy feliz, muy conchuda, porque el gringo les dejaba una televisioncita así para esos años, en México, era un lujo tener una televisioncita portátil, la dejaban regalada, la bicicleta, sus bicicletas, abrigos, zapatos, y venían al próximo verano, se sentía felíz, si le pagaban con eso, nunca hubo una queja....(Hombre de 67 años, profesionista, originario)

El ambiente en San Andrés para estos grupos, es diferente ahora, la relación social con los originarios es difícil de construir, sobre todo cuando son de escasos recursos, sin embargo prefieren tolerar esto que a la ciudad. Eligen San Andrés por sus atractivos naturales y ambiente relajado pero lamentan algunas actitudes de desconfianza de parte de sus caseros, que los hace sentir vigilados en su propia casa. En el caso de los que tienen hijos en edad escolar, deben enfrentarse al rechazo de parte de algunos padres de familia o maestros que no aceptan ni aprueban su forma de vestir y actuar, ni toleran la cercanía con los suyos, por esta razón deciden socializar lo menos posible reuniéndose en sus casas o en espacios abiertos con otros grupos similares, como ciertas calles a determinadas horas, en las afueras de algunos antros. Su nivel de vida es austero, espacios como el de Container City, los desconocen. En ocasiones cuando grupos musicales populares llegan a Cholula a dar conciertos masivos, o durante las ferias locales, asisten como única forma de diversión y sobre todo para vender sus productos artesanales, pinturas, ropa, etc..

Hippie extranjera:

De origen vasco, llegó para realizar una estancia en la Universidad de las Américas donde estudió durante un año. Refiere haberse sentido bastante incómoda con el ambiente estudiantil, definiéndolo como "otro mundo que comienza a partir de la puerta de acceso"; no entiende la 
actitud discriminatoria con la que muchos mexicanos se tratan entre ellos mediante el uso de la palabra "indio" y le asombra el lujo de algunas discotecas que se encuentran en San Andrés, regresó en plan vacacional y le gustaría quedarse definitivamente porque encuentra una calidad de vida inexistente en su tierra natal, como la tranquilidad y sencillez de la gente que la ha respetado y solo refiere en una ocasión haber recibido un insulto en la calle de parte de los sanandreseños.

Este grupo se instala en San Andrés actualmente en la búsqueda de un hábitat más hospitalario, amable y de encuentro con los que son "igual a ellos", valorando la tranquilidad y la vida menos exigente que en la metrópoli. La falta de ingresos y la exclusión social los expulsa de la ciudad, encontrando en San Andrés un espacio menos conflictivo que el de la ciudad. Sin embargo, en este caso tampoco se cumplen todas sus expectativas, ya que el ambiente de marginación de la ciudad es reproducido por la sociedad sanandreseña y por los avecindados de mayor poder adquisitivo. La creación de nuevos espacios de consumo los excluye, son lugares con significados muy distantes a los de su preferencia.

\subsection{Las y los originarios.-}

Las visiones son divergentes en este grupo: Hay quienes se muestran inseguros y preocupados por lo que sucede a su alrededor y por sus familias, admitiendo sentirse rebasados por la rapidez del cambio en su entorno y lo irreversible de estas nuevas situaciones que enfrentan. Existen otros que niegan esta realidad o la admiten sin percibir una pérdida de control, otros más están formando parte del cambio que aprovechan para su propio beneficio.

Familias clase media:

En el primer caso, una madre de familia recuerda y añora su anterior estilo de vida que ahora sus hijos más pequeños no tuvieron oportunidad de vivir. La actividad lechera que durante mucho tiempo fue negocio de sus padres y de ellos, se terminó y su esposo ha tenido que cambiar de actividad económica varias veces, aprendiendo varios oficios e integrándose recientemente a la construcción. Encuentra cambios preocupantes en sus hijos que la sorprenden en cuanto a la percepción del ambiente actual que a ellos les preocupa pensando en la educación como forma de tener un mejor nivel de vida y capacidad de decisión. Sin embargo y en forma reiterativa, encuentra que había una mejor calidad de vida antes de que la urbanización la enfrentara a situaciones desconocidas con las que está aprendiendo a lidiar:

Yo les digo a mis hijos "antes no había luz pero era más seguro....ora hay más luz.. ¿ y está más inseguro?. Ora hay que estar más al pendiente, no todos son malos, debe haber uno o dos que venden la "mota" pero uno tiene que estar con los ojos bien abiertos...Pues yo les digo a mis hijos 
que a mi me gustaria que regresaran los tiempos de los calzones de manta y ellos me dicen: hay tú te quedaste traumada con eso....ven fotos viejitas, de la gente descalza y les digo así andaban todos, a ustedes ya les toco desde que nacieron zapatos... Ahora mi hija me dice: ya quitate ese mandil, ¿pa que te lo pones?....pues para cocinar ... ¿y que no puedes cocinar sin el mandil?...no le gusta"(Mujer, 37 años, ama de casa, originaria)

El primer temor que expresó fue por la presencia de grupos indígenas que desde hace diez años llegaron a San Andrés en busca de trabajo y mejora salarial, actualmente dispersos en toda la cabecera municipal. Se les acusa de cometer delitos como robo, asaltos a mano armada y asesinatos recientes. Lo inquietante de esta situación es que, según ella, se están haciendo pasar por sanandreseños, y confunden tanto a las autoridades como a los avecindados.

Pues no hace mucho acuchillaron a uno por acá y luego dicen que somos nosotros, los de acá, y no porque son los de Veracrúz, unos de un pueblo que se llama Altotonga. Entonces se han venido muchos de por allá y de la sierra norte y están por todos lados. Luego se da uno cuenta por su forma de vestir, sus sombreros...(Mujer, 37 años, ama de casa, originaria)

Como parte de esta convivencia con grupos extraños que exige a la comunidad una reconfiguración de sus relaciones sociales, recordamos que Rossana Reguillo dice:

Los relatos marcan zonas de fragilidad o vulnerabilidad para distintas personas y grupos sociales, como es el caso de ciertos espacios urbanos genéricos, los barrios pobres, mercados populares, algunas plazas y calles, que son marcados por un espacio de peligro a priori representado por figuras peligrosas que amenazan la seguridad de los sujetos. Las fuentes de peligro no son los espacios urbanos genéricos, dice la autora, sino sitios especificos como "la vecindad de la esquina" y figuras concretas como "los chavos" "las pandillas" que se congregan en diversos sitios. (Reguillo, 2004:38)

Lo anterior se agrega a los temores que causa la pavimentación de las calles y aumento de tráfico que ya ha ocasionado algunos percances automovilísticos, los cobros por el servicio de limpia semanal que de alguna manera les sorprende y por la convivencia cercana con estudiantes a quienes la familia les renta cuartos, que tienen que ver con la expresión de costumbres diferentes que los obliga a explicarlas a sus hijos pequeños que los interrogan y a los jóvenes que los imitan. 


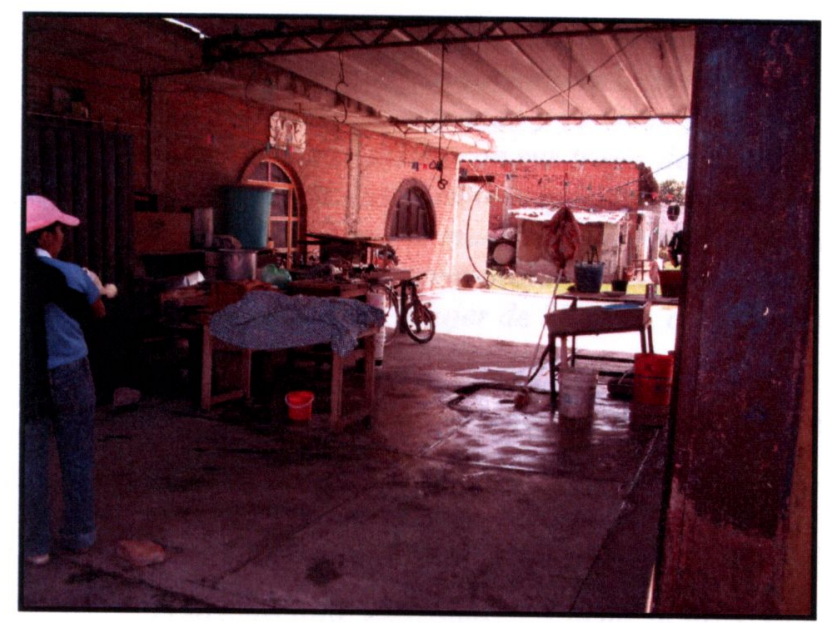

Casa y negocio de originario

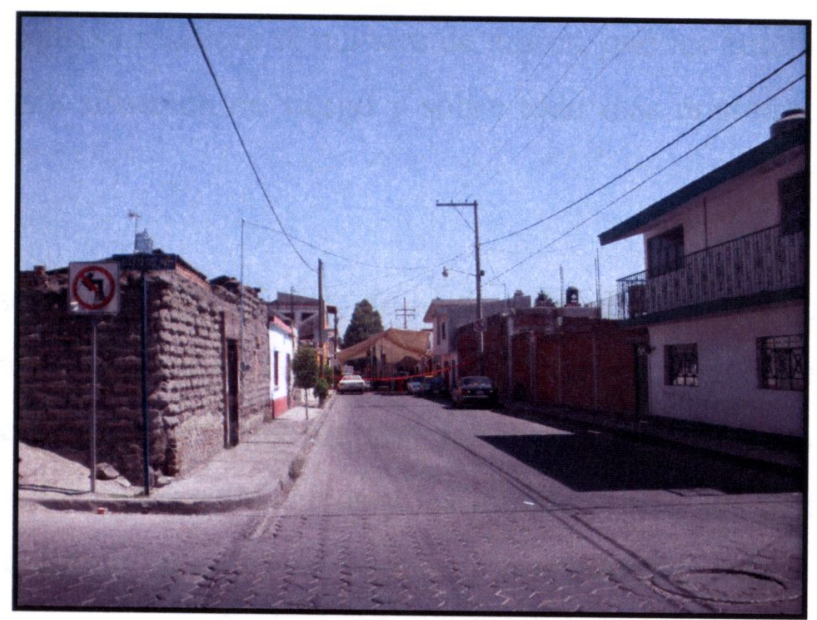

Casas originarios, B. Santiago

El inquilinato se presenta como una actividad económica que los sanandreseños están generalizando como una manera de percibir ingresos que compensen a las tradicionales actividades económicas abandonadas o en proceso de abandono en la agricultura y la ganadería, enfrentando problemas serios por hacerlo de una manera "informal", sin contratos, sin aval y en ocasiones sin depósito, demoras para el pago de renta y la salida intempestiva de los inquilinos que dejan adeudos y maltratado el lugar. En otras ocasiones se ha sabido de abusos de parte de los originarios que obligan a sus inquilinos a pagar muebles inicialmente deteriorados que por el uso llegan a romperse, por lo cual como medida precautoria es común antes de rentar, informarse con algún vecino o conocido antes de decidir, de qué tipo de casero se trata. Esta actividad económica se generaliza, los espacios familiares son compartidos, en una relación mediada por la desconfianza, la ingenuidad o la intolerancia, opinando que: 
Pues está bien, aunque también hay unos estudiantes perjuiciosos y sobre todo que ahi andan, tomando, fumando esa cochinada ... si nosotros no consumimos eso.. Y luego a este niño le llama la atención estarlos espiando y y a viene y me cuenta....Porque yo no se que tanto hacen, pero luego las muchachas se visten con sus trajes de hawaianas, o luego se ponen unos como de enfermeras con sus faldas cortitas y quien sabe cuánto hacen. Ya en la madrugada ahi se andan jaloneando la muchacha y el muchacho pegando de gritos... ¿y yo que pensaba que los que tienen más dinero eran los mejor comportados?, pero mientras no se metan con nosotros, pues allá ellos... y es que son estudiantes...(Mujer de 37 años, ama de casa, originaria)

Le inquieta también la presencia de hijos de avecindados en la escuela de su hijo, pues le asombra que hablen de ciertos temas que, de acuerdo con ella solo los adultos harían. Finalmente cuando se le pregunta qué ventajas encuentra en los recientes cambios para sus hijos responde:

¿Para ms hijo?s....Nada $\ldots$ Bueno va progresando porque más antes todo estaba lleno de terrenos, de plantas... ahora ya hay luz pero... si me gusta todo de acá para mis hijos(Mujer de 37 años, ama de casa, originaria).

En un futuro lo que quisiera es que se redujera el número de antros, que las autoridades se hicieran cargo de supervisar y frenar esta situación de riesgo y sobre todo más oportunidades de trabajo para sus hijos.

Esta persona de 37 años representa a un alto número de madres de adolescentes que les ha tocado presenciar grandes cambios en la comunidad de manera acelerada y ahora enfrentan un contexto social transformado, que cuestiona los valores de una familia tradicional, los lleva a socializar con estilos de vida y valores diferentes a los suyos y les impide repetir los patrones de educación de sus padres, desorientándose ante los retos del arribo de la modernidad que sus hijos prefieren. Desean una mejor educación para sus familias adecuada al contexto actual que les permita insertarse en la sociedad local como profesionistas y ellas mismas se preocupan por capacitarse en la idea de apoyar a sus familias.

\section{Autoridades Comunitarias:}

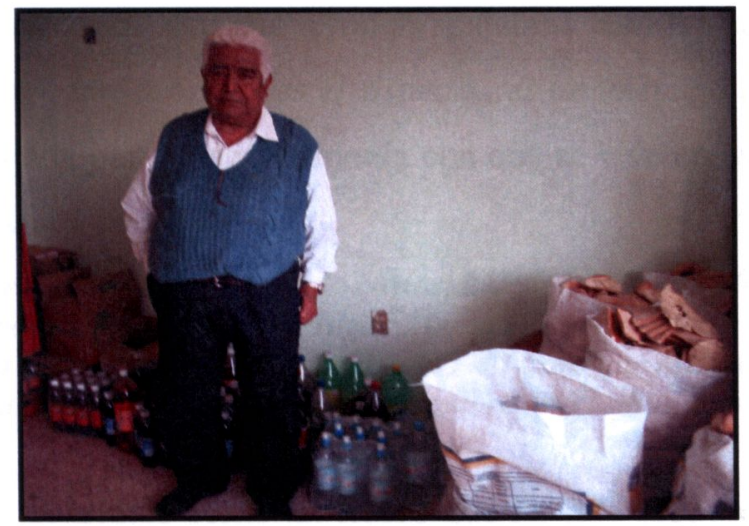

Autoridad comunitaria, B. Sta. María 
En el segundo grupo encontramos a un hombre de 71 años, que bien podría definirse como líder nato, con una formación autodidacta y participante en varias luchas sociales como representante de su comunidad, enfrentando a autoridades locales y estatales que han querido intervenir políticamente en el municipio formando parte de la Comisión de defensa de límites territoriales de San Andrés en los años noventa y a realizar por su propia cuenta una investigación en el archivo general de la nación para obtener el "plano original" que lo lleve a ganar la lucha sostenida. Ha ocupado constantemente cargos comunitarios y religiosos, es reconocido como autoridad a quien se le consulta la toma de decisiones importantes que afectan a la comunidad, a la vez como una persona "erudita" sobre la historia social y religiosa de San Andrés.

Su ocupación ha sido como agricultor, comerciante y ganadero. Vive en el centro de San Andrés en una casa herencia de su abuelo, la cual comparte con su esposa, dos de sus hijos ya casados y sus nietos. Se interesó por aprender veterinaria lo cual le permitió practicar esta profesión durante muchos años. Actualmente practica la ganadería en pequeña escala y opina sobre el cambio:

Si todavía, todavía, si pues esa fue su mayor fuente de ingresos de la comunidad. Ahora ya las vacas se convirtieron en taxis, muchos se fueron de obreros, entonces... ya es otro nivel de vida.

Recientemente ha construido en su propiedad tres o cuatro cuartos para rentar, lo cual valora como beneficio derivado de la urbanización:

Si porque por lo menos construimos departamentos y ya podemos rentarlos, a menos costo, a menos costo.... por allá(por la UDLA), un departamento de a 1,500 nadie se lo renta, los que cobramos menos somos los que rentamos acá.... Si ya tengo atrás de la casa dos departamentos Tengo uno con dos cuartos y su baño, 1400. Pero ahorita lo voy a remodelar.tengo todo rentado, pero pal 3 de mayo... ya queda libre.. Aqui mi vecino construyó 15 cuartos y pide 500 de renta, pero con baño compartido. Pero fijese usted 500 pesos está bien..... aqui a la vuelta están los baños públicos(Hombre de 71 años, ganadero, originario)

En este caso existe una representación diferente acerca de los cambios que están sucediendo actualmente en el municipio. En sus propias palabras es "enfrentar al enemigo de otra manera....pero el enemigo que tenemos es el sistema...es un enemigo disfrazado". Para él la gente que está llegando es atraída por la paz y armonía con que se vive en este lugar poniendo en primer plano el que "aqui todos se conocen":

Les hace llegar más que nada la curiosidad, de... cómo se vive con gran tranquilidad, armonía, todos nos conocemos en este lugar...La nueva gente están encontrando lugares y ya le están dando vida a la pirámide, van encontrando el tesoro que estaba enterrado.... Entonces nosotros empezamos a proyectar todo esto s(Hombre de 71 años, ganadero, originario)

La pirámide la considera como un tesoro que ha sido saqueado por instituciones como el INAH, del que aún se conserva una parte que atrae y está adquiriendo vida recientemente...La 
comunidad es y proyecta todo eso. Valora su cultura y pasado histórico opinando que los conquistadores son los culpables de la pérdida de valores:

Eran unos grandes alfareros, unos grandes comerciantes, unos grandes estudiosos, ...las caravanas que venían desde Groenlandia, del norte, como de Chile, del sur,.... llegaban aquí a la pirámide, pero no había como ahorita todo esto moderno....venían a ver que habia.... La curiosidad de saber que...Si porque habia una gran cultura, muy estudiosa, una gran civilización... entonces nosotros estábamos platicando de que, son los espíritus que deciden vivir en este lugar... no los vemos pero ahí están, .... los seres humanos nacen para Dios y Dios quiere que los seres humanos vivan en armonía, creo que es lo que estamos haciendo.... Esta cultura así es....pero los conquistadores en lugar de que nos beneficiaran nos perjudicaron...Porque los que nos vinieron a conquistar fueron los malos, los ex presidiarios.... La escoria... por eso nos dejaron todos los defectos: la discordia, todo lo que deteriora a la sociedad. Cuando llegó Cortés, se quedó admirado de la gran pirámide, cómo tenía sus jardines colgantes.... Sí, ahi Bernal Díaz del Castillo narra en su libro... ¿no la usted leído?... Entonces nosotros teníamos la idea de llegar hasta Sevilla a conseguir los planos originales, entonces, ¿qué necesitamos? Nomás necesitamos seguir presionando, hacer una solicitud al gobierno federal... yo ya hasta preví cómo vamos a hacer las cosas... (Hombre de 71 años, ganadero, originario)

Asegura que al igual que en la época precolonial, la gente llega animada por la curiosidad y es atraída por sus valores culturales. Encuentra que están en una mejor situación que antes, porque ahora ya pueden construir sus departamentos y rentarlos, como un ingreso adicional. Piensa que el beneficio de un pueblo es la preparación por lo que valora como parte de los cambios, la presencia de más escuelas y universidades, lamentando sin embargo que las autoridades no estén bien preparadas porque si así fuera, San Andrés estaría en una mejor situación. Se presenta ante las autoridades locales con la confianza originada por las relaciones de parentesco y residencia de los recientes profesionistas que han ocupado cargos en la presidencia municipal y la experiencia de situaciones vividas para exigirles el cumplimiento y acciones necesarias ante situaciones de riesgo. Y en cuanto a las autoridades estatales opina:

El gobernador es el que manda en todo el estado, administra, pero no es el dueño de los pueblosj..ahi está la diferencia....¿Eh?.. entonces los dueños de los pueblos son los ayuntamientos, ellos son los que ahi viven y saben cómo mantienen a su gente.

Antes que nada, en un acto de aceptación de este fenómeno ha dicho a sus compañeros: " $L a$ ciudad ya se nos vino encima y no lo podemos detener" y para conservar el orden urbano sugiere que cada junta auxiliar haga sus planos para conocer su territorio y evitar problemas futuros. Desde hace muchos años tiene un proyecto que él mismo ha creado: "un mercado mundial que promueva, organice y controle la comunidad y que tenga intercambio con otros mercados mundiales conformando un espacio en el que se vendan productos comestibles de todo el mundo". Este proyecto lo ha presentado a varias autoridades que no lo han escuchado y espera animosamente llevarlo a cabo. 
Habla de varias estrategias que la comunidad tiene como forma de control de la situación actual de interacción con avecindados: A los dueños de restaurantes y bares solo se les renta el terreno, nunca se les vende; el precio de los terrenos los pone la comunidad y con eso los espantan; a él lo consultan con relación al precio de venta cuando se presenta una oferta de compra de terrenos para empresas que desean establecerse en el municipio:

Nos hablan las empresas cuando tienen proyectos, llegan los coyotes esos... vinieron una vez, vinieron también los muchachos y me dijeron: quieren que les vendamos, ... ¿ cuánto quieren? 50 has.... ¿ y que dijeron ustedes? ... Que lo que usted diga, ... mmh, ¿ y les gusta? ... sí,.... Pues a $\$ 1,500.00 / h a \ldots . .$. entonces los coyotes dijeron: i no aqui está muy caro $;. .$. Pero, nosotros no queremos dinero, queremos nuestra tierra, entonces no..... ha y uno que otro que si vende".

En general se manifiesta bastante seguro con esa estrategia de control sobre el territorio expresando que "nosotros vamos a ser los pedestales del desarrollo de este municipio". Tiene la percepción de "vivir en la ciudad", que se distingue también por el ambiente festivo, en el que incluye a la zona de diversión de y para avecindados en la 14 oriente, considerando que se trata de vida, bullicio y algarabía, equivalente a una fiesta permanente porque la gente se siente felíz y a diferencia de la metrópoli, se vive en orden y armonía. Considera que la urbanización tiene que ser para bien: "Y es que nosotros ya nos dimos cuenta ....no podemos pararla"

En ambos casos, la comunidad sanandreseña enfrenta varios problemas, en ocasiones mediante la actitud del "debe ser" que nos habla de una adaptación a las circunstancias actuales que exigen de estrategias de subsistencia económica como el inquilinato, en las condiciones mencionadas anteriormente de informalidad, que genera situaciones de conflicto y pérdida de ingresos. Como organización comunitaria se perciben fracturas al interior por las presiones que actualmente ejercen las autoridades gubernamentales, empresariales o institucionales, sobre dicha organización, sus tierras y sistema de vida, que logran mantener al estar vinculadas a la memoria y tradición, convirtiéndose ahora en recursos de sobrevivencia ante situaciones de cambios violentos como los que actualmente enfrentan.

Promotores del desarrollo(modernizadores):

De campesino a profesionista y dueño de empresa, ha sido una trayectoria de experiencias múltiples que en este caso, lo convirtió en una persona diferente al resto de sus paisanos sanandreseños, opinando que el verdadero problema de la comunidad es la ideosincracia de la gente, que se siente autosuficiente, es apática, convenenciera y no emprendedora, encontrando en la falta de educación un motivo que explica su conformismo:

(...) la gente de San Andrés tiene un gran problema, se siente autosuficiente, mmhh.. como ejemplo le voy a poner un caso, en la actualidad todos tienen casa, todos tienen terreno, y ahorita la 
gente vive de que va vendiendo... pone un negocito o se va a trabajar de lo que sea, un oficio, cualquier cosa, pero así así de que tengamos un área productiva en San Andrés, no la tenemos, no tenemos mercado, no tenemos agua potable, ¿ porqué? Porque se argumenta que tenemos pozos, no la necesitamos, en fin... entonces eso ha mermado el desarrollo de la población, la falta de criterio, pero más que de criterio, de educación, si porque aquí no hay gente emprendedora, ahí va viviendo, el que es mesero es mesero, el que es albañil, es albañil, el que va a la fábrica es fabricante, y así.... Al fin y a al cabo tienen su casa, tienen su terrenito, y si no, pues, ya se va acabando de que van vendiendo los que tienen, y si usted tiene casa grande, por ejemplo yo vivo ahorita, yo.... pus tengo dos hijos, y si tengo más, pus aquí los acomodo, y si tienen más pus ya los van acomodando y ya se va haciendo así, pero ya no es el pueblo de antaño que era,(..) pero es por la falta educacional(Hombre de 67 años, profesionista, originario)

Habita en una casa del centro de San Andrés, con características similares a las tradicionales del lugar ${ }^{29}$. Como parte de sus actividades, desde hace varios años se inserta en la compra-venta de terrenos, lo cual le permite independencia laboral y posteriormente convertirse en empresario. Se describe como una familia de profesionistas con mentalidad progresista que han desempeñado trabajos diversos en la ciudad, participó con un cargo en el ayuntamiento priísta, y actualmente encamina a sus hijos en carreras universitarias o como futuros dueños de algún negocio. Sin embargo al preguntarle acerca de la opción que tienen los profesionistas egresados de carreras universitarias en su propio municipio responde que la migración, ya que existe una situación de nepotismo en el gobierno y los puestos están coptados, describiendo las cosas en el municipio de la siguiente manera:

No hay un despegue. Ahora, que San Andrés ya creció, a lo mejor tenemos la gente ya capacitada, sí, pero le falta el oficio, ... yo lo comparo, por ejemplo con la República, con el presidente de la República, que fue Fox, que ahorita es este Sr... les faltó el oficio politico.... A Fox no lo dejaron hacer ninguna reforma, a él, su interés fue sacar al de los Pinos del Partido, y así fue acá, sacar el partido de los Pinos y ahi está, que le interesa el campo, ¿el campo porqué? Porque él puede......, riego por goteo, que da muchos beneficios... pero es porque puede, pero que vaya con los pobres desgraciados aqui de las zonas marginadas, que les vaya a rascar un pozo.... Pues no, nomás no..éste, el del empleo, pus no en lugar de tener empleo, pus va pa trás el empleo... (Hombre de 67 años, profesionista, originario)

De cincuenta años a la fecha, considera que en la comunidad "ya hay más uso de razón" y es algo que vincula al desarrollo aunque por otra parte es crítico de los cambios en cuanto a las tradiciones festivas, en su forma de organización y presentación, culpando a la misma gente y a la proximidad de las franquicias como inductoras de cambio:

Hoy ya salen en carro, anteriormente era caminando y en carretas tiradas por mulas...veía a las gentes con su "ceñidor", huaraches, calzoncillos... en ese entonces, todos de sombrero.... hoy casi nadie ya usa sombreros, usan zapatos, carros, los únicos que van con la música son los encargados, truenan sus cuetes y ahi andan, realmente un mundo diferente al de hace 60 años que le estoy diciendo, ... hoy no ... que les dan jugos, que les dan un sándwich, que les dan una torta en cada parada, y a la comisión y al mayor que ya le dan una botella, son las 10 de la noche y andan

\footnotetext{
${ }^{29}$ Nota: Las casas de originarios todavía se reconocen por sus similitudes: Una sola planta, paredes de adobe, patio central con un espacio destinado a la cría de animales domésticos, habitaciones dispuestas alrededor de éste, cocina separada del resto de la casa.
} 
ya bien cuetes, es lo que se ha incrementado, el alcoholismo...... la gente de acá, hacía su molito ... hoy la gente hoy en día, casi nadie hace mole más que el encargado, porque la gente come como cualquier día del año, se va acabando, desapareciendo ... y ¿porqué? 'porque a los hijos ya no les gusta eso, criar el guajolote, matar el guajolote, ora es muy fácil: cómprate un pollo, cómprate puras piernitas, pechugas, y de eso hacemos el molito, o si no, un pollo rostizado y ya comimos, .... y eso ¿quien nos los ha traido?, pues los avecindados...y las firmas extranjeras, transnacionales más que nada...pues ahi tenemos a un Burguer, ahi tenemos a un Mc Donalds(Hombre de 67 años, profesionista, originario)

Nunca ha participado en algún cargo de la organización comunitaria y considera que el futuro de la comunidad es la desaparición de usos y costumbres: en no más de tres décadas se va a acabar el espacio en San Andrés, los jóvenes profesionistas van a migrar por la falta de empleos en la comunidad y las familias se van a agotar sus recursos que les han permitido sobrevivir en la actualidad. Desde su punto de vista el proceso de urbanización es para bien, está de acuerdo con las nuevas zonas de desarrollo y la presencia de avecindados que según él, han encarecido la vida y no han traído ningún beneficio a San Andrés, sin embargo, su presencia motiva a la superación de todos, aunque contribuyan a la desaparición de las expresiones festivas:

Mire la urbanización ha hecho que nuestra gente vaya cambiando, se vaya preparando y vaya adquiriendo otra mentalidad, ¿el costo?... perder todos sus usos y costumbres y la ideosincracia, sí..... aqui vive un señor de Monterrey, tiene una casa muy bonita, trabajador de HILSA, compró, hizo su casa,... al señor le pasan a tocar para las cooperaciones y el señor nunca está $;. .$. viene a dormir... sale la empleada: pus no está el patrón, ... y así, no sabe nada de usos y costumbres;(Hombre de 67 años, profesionista, originario)... el beneficio que han traído, que sea costosa la vida, más costosa, que los terrenos sean carísimos, que pues... ya tenemos servicios, estamos dotados de servicios y todo, y que la gente ya se prepare...ése es el único beneficio... ya los ven y ya...la gente ya no quiere quedarse tan estancada, que todavia faltan treinta años para ver ese estancamiento, que de frutos, de momento, no va a haber, pero para cuando esos treinta años lleguen, San Andrés ya se perdió, porque vamos a estar más llenos de avecindados, que los de acá. Le digo por esto, porque el profesionista que se va haciendo maestro, doctor, trata de salir, en cambio el avecindado ya viene, pero ya viene con cierta mentalidad, si es ingeniero ya trae trabajo, o ya viene o ya lo mandan de otros lados, pero ya tiene sus empleos ya tiene todo, a él ya no le preocupa, ... Ellos comprando, exactamente, lo que me rodea es para mi, haga de cuenta que es la misma ciudad de Puebla, ...

En general se muestra bastante crítico hacia sus paisanos por mantener una actitud opuesta al progreso, atribuible según él a la falta de educación. La educación que él recibió y sus gustos personales, le permitieron el "despegue" de la vida comunitaria a la profesional, la política y actualmente la empresarial. El conocimiento de sus paisanos y sus actividades económicas lo constituyen en un actor intermediario entre autoridades, empresarios, avecindados y originarios. Su lucha es política y económica y está a favor de la urbanización. La visión que muestra de los originarios, va en relación con la falta de urbanización que en este momento presenta San Andrés con relación a Puebla, para que sea una ciudad y no un pueblo adentro de la ciudad. 
Encontramos que tanto en los avecindados como en algunos vecinos, ya existe la percepción de estar viviendo en la ciudad, pero una ciudad con elementos que de acuerdo al grupo del cual estemos hablando, son destacados. En el caso de los empresarios, por sus atractivos patrimoniales y servicios educativos, su ubicación socio-espacial, extensos terrenos y espacios verdes aprovechables para ciertos estilos de construcción, condiciones que permiten su conversión en una "ciudad creativa", especial para gente joven, clase media-alta y el turismo. Los "yuppies" anclados al ambiente estudiantil o empresarial, con intereses en la gastronomía, el turismo y en la conformación de un ambiente local-global vinculado a sitios como New York, Holanda o Inglaterra. Los hippies, lo ven como un lugar esperanzador que evoca otros tiempos de sueños de amor y paz. Los avecindados por su arraigo histórico, el orden socio-espacial, la urbanidad de la gente y la plusvalía del terreno que podría convertirlo en otro Coyoacán, aunque preocupados por varias tareas como modificar "ciertos usos y costumbres" y convertirlo en un lugar más agradable. Los originarios anclados a su pertenencia socio-territorial, con un alto aprecio alrededor de su pasado que los distingue ante los demás grupos que llegan atraídos por esas cualidades y expresiones constantes de tradiciones identitarias que los distinguen como grupo, esforzados en adaptarse a la situación actual del municipio mediante el ejercicio de nuevas actividades y estrategias económicas aunque en forma lenta pero aún consensada. Los originarios empresariales, son hábiles conocedores de la ideosincracia de sus paisanos, se presentan como mediadores con los actores externos aprovechando el momento de transformación socio-espacial y económica actual para realizar convenios y negociaciones con autoridades, empresarios y originarios, que persiguen beneficios personales, valoran el territorio por su potencial económico y enfrentan la urbanización abiertamente y en esos términos lo defienden. Los actores políticos que ejercen presión desde el estado, crean alianzas con los empresarios y controlan mediante estrategias gubernamentales y partidistas la zona. Las autoridades locales muestran intereses diversos en el aprovechamiento del auge económico actual en distintas áreas, apostando a la urbanización de la zona como estrategia política para permanecer en el poder y realizan otras acciones que de igual forma adquieren visibilidad ante la comunidad, como la renovación de San Andrés y la defensa del patrimonio histórico, vinculadas a la instalación de proyectos turísticos. Sin embargo, desde cada postura se contribuye a un proceso acelerado de transformación urbana en San Andrés, con acciones que tienen que ver con la apropiación espacial y la gestión de espacios públicos, para la defensa o desposesión territorial, con intereses en ocasiones opuestos pero que responden al objetivo común del ejercicio de un control territorial, elemento que demuestra desencadenar situaciones de tensión y conflictos urbanos. 


\section{CONCLUSIONES}

En este primer acercamiento a San Andrés Cholula, se definieron los objetivos de la investigación, encontrando en la gestión y conformación de espacios públicos, resultantes del proceso de extensión de la metrópoli y de la puesta en marcha de acciones y estrategias a escala global, transformaciones socioespaciales generadoras de procesos de reacomodo social y económico en la población originaria, que muestran a una sociedad en proceso de adaptación a los cambios de su entorno, construyendo su relación con la ciudad y redefiniendo las relaciones y estrategias de acción con los grupos diversos que actualmente lo habitan.

La expansión urbana de la metrópoli ha sido expuesta en este documento, como un sometimiento a políticas impuestas desde el exterior, a un territorio privilegiado con riquezas territoriales, un gran número de bienes patrimoniales, de origen rural y próximo a una metrópoli, lo cual es valorado para su explotación económica y explica el acelerado avance urbano en la región. Sin embargo, por tratarse también de un territorio apropiado y valorizado por actores de origen indígena, que históricamente lo han habitado y reconocen en él un patrimonio socio-cultural y espacio de inscripción del pasado(Giménez, 2000:38), con un largo proceso de relaciones y contacto con otras regiones y colectividades, se presentan tanto molestias y acciones de resistencia a la urbanización como muestras de colaboración y apertura a dicho proceso, provocando situaciones de tensión y conflicto que muestran a una comunidad en continuidad y cambio por el dinamismo reciente de la urbanización.

Es en la puesta en marcha de estrategias por los diversos actores sociales que lo intervienen y habitan, en la apropiación de espacios y construcción de límites y fronteras simbólicas, donde se expresa una interacción grupal con la comunidad originaria, que ante un hecho irreversible, visto por muchos tradicionalistas, como la invasión de la ciudad, también actúa, negocia y toma decisiones ante la disyuntiva de participar, como comunidad en la defensa territorial o en forma individual, para la obtención de beneficios económicos, según del tipo de actor que se trate.

\section{Separación espacial y conflicto:}

El espacio, lo hemos considerado como capacidad para hacer, con una dimensión política, que funciona para la obtención de satisfactores, en el que se afirma y se ejerce el poder. La separación espacial en la conformación del lugar, entendida como la creación de espacios de uso 
preferencial por y para grupos de avecindados, se elige como estrategia de delimitación de zonas de acción grupales, en una pretendida acción de invisibilizar al resto de la sociedad que tradicionalmente lo ha habitado. Con esta acción también se pretende desconocer las relaciones simbólico-significativas, históricamente establecidas, que la gente originaria mantiene con el territorio, que responden a una memoria y valores compartidos. En este sentido, una vez establecidos en el lugar, las relaciones entre ambos grupos se vuelven necesarias, presentando complicaciones y efectos inesperados que se deben resolver. Como parte de la imposibilidad de una separación definitiva con el resto de actores locales, surgen las acciones y relaciones de los gestores de estos espacios con las autoridades locales, para exigir que cumplan con su papel de mediadoras entre la comunidad y los inversionistas y con todas las demandas y servicios básicos e infraestructura necesaria, para hacer redituable su inversión, lo cual resulta complicado entre otras cosas por el mismo proceso acelerado de urbanización que las ha rebasado, o por tratarse de grupos externos y con una afiliación partidista(PRI) distinta a la del gobierno local actual(PAN), a quienes se mantiene en espera o en una relación problemática que impide la solución inmediata de problemas.

La creación de espacios para avecindados, como construcción de mundos separados del contex́to social que los circunda, resulta una práctica segregacionista, que demuestra un interés particular a partir de su apropiación, por mantener y reproducir estilos, gustos y una concurrencia de gente como ellos, generadora de un ambiente de descontento y violencia en la comunidad. En un caso similar se encuentran las familias de avecindados residentes en la localidad, que imaginaron a este lugar "vacío" o carente de las relaciones densas que lo conforman, manteniéndose en una situación ambigua en la comunidad, en permanente molesția y/o empeño por modificar algunas de las prácticas sociales de la comunidad, pero en la certeza de poder exigir el respeto a sus derechos como residentes del lugar que aparece en el centro de su argumentación ante las autoridades.

\section{Los proyectos:}

La aplicación de proyectos de distinta envergadura, demuestra el interés que sobre este espacio ha surgido en distintos ámbitos y grupos de poder, con una falta de control de los mismos. Definidos externa e internamente, han contribuido además de la transformación territorial, a una alta plusvalía e incremento del costo de vida, cambios de uso de suelo y a la creación de ambientes e inserción de sujetos distantes al contexto local. Aunque tales proyectos provengan y sean aplicados en distintos ámbitos, comparten una visión empresarial: como inversiones de capital económico y político que deben ser redituables y permitir ganancias sobre el espacio: de 
localización, posición y ocupación que se traduzcan en capital económico y político, sin importar el costo social que derive de su aplicación o las consecuencias en el lugar, dejando siempre fuera a la comunidad. Los proyectos de las autoridades locales tienen coincidencia con los empresariales, en cuanto a objetivos y posturas: apoyando la modernización de la cabecera municipal a través de una urbanización acelerada y la implantación de aquellos proyectos que buscan un giro hacia actividades turísticas y comerciales, que pretenden impulsar como prácticas económicas a las que paulatinamente se integren los originarios, sustituyendo a las tradicionales que se ven debilitadas . por la falta de apoyos.

\section{Los actores:}

Existe una imbricación de actores vinculados a los distintos proyectos en la comunidad, que intervienen desde distintos ámbitos: vivienda, negocios, instituciones privadas, poderes estatal y federal, que mantienen relaciones y actúan articuladamente desde el lugar y posición que ocupen, permitiendo y fomentando la infiltración de poblaciones de los sectores con alto poder adquisitivo o en etapa ascendente, disparando las diferencias socioeconómicas y culturales entre avecindados y originarios. Consecuentemente, las relaciones jerarquizadas entre actores que intervienen en cada uno de estos espacios se extienden y permean al contexto social, alterando paralelamente las cotidianas del lugar ante la multiplicación de grupos y espacios con límites y fronteras, anteriormente desconocidas, resultantes de la transformación socio espacial que se vive y provoca un reacomodo social.

El gobierno local, ocupa un sitio importante en la redefinición de espacios en diversos puntos del lugar, como actor que negocia con los grupos locales y externos en la aplicación de proyectos y que aplica nuevas políticas públicas relacionadas con el uso y reglamentación de los mismos. Son defensores de la modernización y modificación espacial y apoyan abiertamente el proceso de urbanización. Existen varios propósitos en esta apertura y apoyo al acelerado avance urbano: 1) como acción política que apuesta a la urbanización para visibilizar su interés en el mejoramiento de espacios públicos, 2) obtener más votos como partido político con posibilidades de mantenerse más tiempo en el poder, 3) apoyar la implementación de proyectos de desarrollo urbano destinados a clases altas facilita la inserción de grupos con mayor capacidad económica y 4) asegurar el alza en el pago de impuestos y servicios.

Otra de sus acciones importantes consiste en el diseño de políticas patrimoniales, aliándose al municipio de San Pedro, que pretenden aplicarse en las cabeceras municipales y juntas auxiliares 
de ambos municipios, a través del resguardo y control del "acervo" patrimonial, su uso y estado. Se trata de políticas concertadas con el gobierno federal, de acuerdo con las emitidas por organismos internacionales, vinculadas a grupos empresariales e institucionales que dejan también fuera la opinión de la comunidad.

Para los sanandreseños de clase media o baja, el momento actual representa una situación de desconcierto e incertidumbre por el futuro de su comunidad y de desequilibrio económico con la que empezaron a lidiar desde hace varios años. Su participación en este proceso debe ser evaluada a partir tal situación, que ha provocado el que las familias, al no contar con liquidez, vendan sus propiedades o las fraccionen para conseguir un ingreso adicional mediante el inquilinato, realizando adaptaciones al interior de su espacio familiar que les permite mantener cierta "independencia", incorporándose al área de la construcción, del transporte y en ocasiones a la de servicios para la cual no se encuentran capacitados, todas ellas como actividades de "sobrevivencia" que los ocupa y conduce a dejar en manos del gobierno local y actores externos, la aplicación de proyectos.

Los actores originarios defensores a ultranza de la modernización, participan en los procesos de cambio, mediante la compra venta de terrenos, actividad exitosa para ellos, a partir del conocimiento interno de la sociedad sanandreseña que poseen, refiriéndonos con esto a lo que ellos mismos llaman la "ideosincracia" y situación económica específica de los posibles vendedores de terrenos, que es aprovechado como recurso y estrategia en las operaciones de compra-venta; les permite además un incremento en su patrimonio familiar y los convierte en aliados empresariales o políticos, adquiriendo un prestigio social ante los nuevos pobladores de este sitio. Rompen los vínculos comunitarios y se vuelven críticos de las actitudes, ideas y prácticas sociales de sus. paisanos que según ellos solo se explican por la carencia de estudios y ambiciones. Visualizan el futuro de San Andrés poblado por un número cada vez mayor de avecindados, que causará la pérdida de tradiciones y prácticas festivas religiosas, que se sostienen por la cooperación comunitaria a la que jamás se insertarán los avecindados. Son defensores de la urbanización acelerada que quisieran similar a la de las grandes ciudades: con espacios recreativos y culturales como cines, teatros, auditorios, etc, acuden a las nuevas centralidades y zonas de franquicias, forman a sus hijos como profesionistas o futuros empresarios y están de acuerdo en que la esposa se capacite y trabaje.

Las autoridades comunitarias, se muestran con orgullo por el atractivo que este lugar ha ejercido ante extraños como lugar patrimonial y santuario religioso, quienes eligen a San Andrés y 
sus alrededores para visitas frecuentes o residencia, con lo cual se refieren a un largo periodo que abarca desde la conquista hasta la actualidad. Reconocen como tesoros principales a la pirámide, el santuario de la Virgen de los Remedios, los volcanes, la calidad y cantidad de agua y tierra. Están conscientes de las riquezas de su territorio y del valor afectivo y económico de las propiedades que aún conservan. Como personajes reconocidos en la comunidad, son consultados por las familias y sus compañeros aún organizados comunitariamente, al recibir una propuesta de compra de terrenos extensos y toman una decisión de común acuerdo. Ocupan cargos en las festividades religiosas y son firmes defensores de sus tradiciones, que se seguirán sosteniendo de las cooperaciones acordadas por ellos mismos. Afirman tener el control espacial ante los empresarios voraces y los avecindados mediante la posesión y determinación en forma consensada, de los precios de los terrenos en renta o venta; ante el propio gobierno estatal y federal, a quien consideran como un "enemigo disfrazado" que en varias ocasiones les ha expropiado grandes extensiones de tierra se mantienen en pié de lucha por la definición de los límites territoriales y ante el local, por tratarse de familiares o conocidos, a quienes pueden interpelar y exigir acciones responsables, justas y cuentas claras en la aplicación del gasto público. Todavía practican, aunque menor escala, actividades productivas tradicionales como la ganadería, lechería y manufactura de productos lácteos, pero muchos de ellos complementan sus ingresos con el inquilinato o el comercio en pequeño. Creen firmemente en que seguirán siendo el "pilar" del desarrollo en San Andrés.

\section{Consecuencias de los cambios en las familias sanandreseñas:}

La urbanización de la cabecera municipal, implica todo un proceso de adaptación a las recientes señalizaciones sobre vialidad y reglamentación en el uso de espacios públicos que originan un cambio de prácticas que anteriormente eran conocidas por todos, se regían por un orden no escrito, pero del conocimiento común sin consecuencias legales o afectaciones en su economía familiar, percibiendo en la actualidad y como efecto de lo anterior, muchas áreas de su entorno como espacios desconocidos, ajenos e inseguros.

$\mathrm{Al}$ interior de las familias, se perciben otro tipo de cambios culturales que influyen sobre la permanencia de valores y expresiones identitarias, originados por la multiplicación de fronteras de distanciamiento social en los nuevos espacios, con efectos sobre la confianza interpersonal y solidaridad social. Como parte de este proceso, se presentan consecuencias en la relación padreshijos como el contraste de opiniones sobre lo permitido y lo prohibido, el rechazo o aceptación de costumbres urbanas, las opiniones en general a favor y en contra de los cambios recientes que se experimentan en el contexto social y de las costumbres religiosas que se mantienen mediante 
cuotas obligatorias que deben cubrir. Como resultado de todo ello, algunas familias trasladan estos conflictos hacia los grupos vulnerables avecindados en la comunidad, como el de indígenas provenientes de la sierra norte de Puebla, a quienes se les responsabiliza de cometer robos y acciones violentas cometidas en la cabecera municipal y por otra parte se justifica, disculpa u oculta a los verdaderos responsables de la creación de este ambiente de incertidumbre e inseguridad.

Hasta este momento, las resistencias de la comunidad solo son evidentes mediante actos simbólicos y algunas acciones territorializadas que se manifiestan ante el traspaso de fronteras en espacios considerados comunitarios. Como ejemplo, el cierre de calles durante las fiestas religiosas y familiares, la restricción que es aplicada a los avecindados que no dan cooperaciones, al momento de solicitar algún servicio religioso que se les niega por no participar en ellas. En el área del zócalo no se acepta la permanencia de comerciantes avecindados que han intentado poner algún negocio, aún con permiso de las autoridades locales, que después de algún tiempo se retiran por las cuotas solicitadas y por algunas acciones que son consideradas como agresivas, de parte de los originarios. Para aquellos que aún reconocen a San Andrés como un territorio propio al que se vinculan afectivamente y que perciben las transformaciones que lo atraviesan, como agresiones encaminadas a la modificación de su pertenencia, surgen las prácticas festivas, expresiones identitarias en espacios públicos, con una gran cantidad de elementos de la modernidad agregados a ellas de acuerdo al contexto actual, representando de esta manera su pertenencia, apropiación legítima y deseos de reconocimiento y permanencia territorial.

Las condiciones del contexto actual, mediante la implantación de modelos globalizados, segregacionistas y de exclusión social, son causantes de fracturas y pérdida de cohesión social al interior de la comunidad sanandreseña, evidentes en las acciones de sobrevivencia de las familias de clase media y la de algunos originarios "modernizadores(Bassand, cit en Giménez, 2000:40)" que apoyan las transformaciones socioterritoriales en San Andrés y los convierte en figuras interventoras en los actuales procesos urbanos que afectan a la comunidad.

Como ha quedado establecido, la situación económica de muchas familias originarias clase media, la de aquellos que aprovechan este momento de auge económico y la apatía de otros, son factores que facilitan la inserción de proyectos con efectos segregacionistas y de diferenciación social en el lugar, dejando en manos de los conductores de los mismos, su manejo y aplicación. Para muchos de ellos, el factor económico conduce al abandono de sus tradicionales actividades económicas y a una forzada inserción en otras desconocidas, como la de servicios, provocando 
efectos importantes como la migración de miembros de algunas familias originarias, que han decidido vender sus terrenos para mejorar su situación económica y por otra parte liberarse de compromisos comunitarios. Este es el caso de la zona territorial del periférico y de la colonia Emiliano Zapata, en donde se han construido un gran número de desarrollos urbanos para la clase social alta y que aún cuenta con grandes extensiones territoriales y de áreas verdes, "disponibles" para la extensión de la metrópoli.

En este sentido se muestra el siguiente cuadro:

\section{Perfil y acciones de actores}

\begin{tabular}{|c|c|c|c|c|}
\hline Tipo de Actor & Orientación de la acción & $\begin{array}{l}\text { Tipo de } \\
\text { compromiso/interés }\end{array}$ & Tipo de Proyecto & $\begin{array}{l}\text { Espacio de } \\
\text { referencia }\end{array}$ \\
\hline $\begin{array}{l}\text { Autoridades } \\
\text { locales }\end{array}$ & $\begin{array}{l}\text { A favor de la urbanización, } \\
\text { inserción de avecindados }\end{array}$ & Político & $\begin{array}{l}\text { Productivos, } \\
\text { Patrimoniales, } \\
\text { modernizantes }\end{array}$ & Político, municipal \\
\hline $\begin{array}{l}\text { Empresarios, } \\
\text { Instituciones, } \\
\text { Constructoras, } \\
\text { Inmobiliarias }\end{array}$ & $\begin{array}{l}\text { A favor de la urbanización } \\
\text { dirigidos a avecindados y } \\
\text { estudiantes }\end{array}$ & Económico & $\begin{array}{l}\text { Productivos: } \\
\text { Comerciales, } \\
\text { Construcción, turismo, } \\
\text { recreación, servicios }\end{array}$ & $\begin{array}{l}\text { Empresarial, } \\
\text { político, } \\
\text { institucional }\end{array}$ \\
\hline Avecindados & $\begin{array}{l}\text { A favor de la urbanización } \\
\text { con carácter tradicional }\end{array}$ & Personal y familiar & $\begin{array}{l}\text { Productivos, } \\
\text { ambientales }\end{array}$ & Familiar, residencial \\
\hline Yuppies & $\begin{array}{l}\text { A favor de la creación de } \\
\text { algunos espacios } \\
\text { globalizados }\end{array}$ & Económico, personal & $\begin{array}{l}\text { Recreativos y } \\
\text { productivos }\end{array}$ & Social y empresarial \\
\hline Hippies & $\begin{array}{l}\text { En contra de la } \\
\text { urbanización }\end{array}$ & Grupal & Ninguno & Grupal \\
\hline $\begin{array}{l}\text { Originarios } 1 \\
\text { (clase media) }\end{array}$ & $\begin{array}{l}\text { Resistencia y participación } \\
\text { en el proceso }\end{array}$ & Familiar/comunitario & $\begin{array}{l}\text { Generadores de } \\
\text { empleo, educativos }\end{array}$ & Familiar \\
\hline $\begin{array}{l}\text { Originarios } 2 \\
\text { (autoridades } \\
\text { comunitarias) }\end{array}$ & $\begin{array}{l}\text { A favor del proceso, con } \\
\text { restricciones }\end{array}$ & Comunitario & $\begin{array}{l}\text { Productivos para la } \\
\text { comunidad, mantener } \\
\text { liderazgo }\end{array}$ & Comunitario \\
\hline $\begin{array}{l}\text { Originarios } 3 \\
\text { (modernizadores) }\end{array}$ & Totalmente a favor & Económico & Productivos, & $\begin{array}{l}\text { Empresarial, } \\
\text { personal }\end{array}$ \\
\hline
\end{tabular}

\section{Procesos de segregación: gentrificación y patrimonialización}

Como se dijo anteriormente existe una amplia variedad de proyectos que excluyen a la comunidad y la población más vulnerable o posibles efectos sobre ésta, tampoco son considerados, lo cual debería darse para la conformación de un ambiente de estabilidad social integrado al proceso de urbanización en este espacio urbano. Como resultado de ello, aparecen procesos causantes de desajustes y problemas de recomposición social como la gentrificación y patrimonialización en la zona, el primero caracterizado por una circulación inusitada de capitales en la zona a partir de cuatro años a la fecha, atraídos y favorecidos por las cualidades del espacio que permite su 
inserción y reproducción, motivando la presencia y/o residencia de grupos de clase media y alta vinculados a instituciones oficiales, académicas, los negocios y la política.

La gentrificación, es un proceso que intensifica las diferencias en cuanto a percepción de ingresos y nivel educativo y fomenta la formación de comunidades permanentemente divididas con relaciones conflictivas. Es generadora de conflictos en el sentido de que se caracteriza por el desplazamiento de poblaciones vulnerables, que en este caso sería la originaria que se convierte en futura migrante, propiciado por el encarecimiento del modo de vida, servicios e impuestos, cambio en el uso de suelo, aplicación de nuevas reglamentaciones jurídicas, modificación de prácticas sociales en los espacios público y privado, que en conjunto impactan a la sociedad sanandreseña y a su economía.

La gentrificación rural(greentrificación) considerada como la vuelta al campo ahora a través de este proceso, teniendo como atractivos fundamentales el "consumo de espacios verdes" y la construcción de "estilos de vida" de tipo rural, instalados no siempre sobre terrenos "baldíos", preferidos y puestos de moda por intelectuales, hippies y yuppies, con presencia importante en la cabecera municipal, es lo que permite identificar a este proceso como una "elitización" del lugar por sus características rurales. En el caso de la Colonia Emiliano Zapata, pudimos obtener información acerca de desplazamientos de propietarios originarios, que han vendido terrenos anteriormente productivos, optando por la migración.

Las modificaciones espaciales y multiplicación de áreas de servicios, con carácter segregacional por la construcción de fronteras simbólicas que los caracteriza, vincula a los procesos anteriores con el de patrimonialización. Este último, apoyado por las autoridades municipales, se manifiesta a través de la sacralización de espacios en el "centro histórico" y el de la pirámide y próximamente los de las juntas auxiliares, con un giro hacia la actividad turística, que pretenden modificar profundamente la estructura socioeconómica en San Andrés, comercializando sus cualidades monumentales y el arraigo histórico que lo identifica, en sustitución de las actividades económicas tradicionales que se debilitan ante la falta de apoyos y baja productividad.

La próxima puesta en marcha de la ampliación de este proceso, como una acción del gobierno local, que objetivice el patrimonio local como un "acervo" y extienda su radio de acción a dos municipios mediante la publicación de un inventario de bienes patrimoniales y reglamentos para su protección con restricciones en cuanto a su uso, aunado a las acciones ya realizadas de 
renovación del centro histórico, se realizan mediante recursos propios como acciones que visibilicen su preocupación por su resguardo y apoyadas en discursos sobre el fomento a los valores históricos e identitarios y activación de la economía local, pero con efectos graves sobre las prácticas sociales y económicas tradicionalmente realizadas por la comunidad y el uso de espacios públicos y patrimoniales de este lugar.

\section{Territorialización: actores y acciones}

Si partimos de que en San Andrés existe una cultura territorializada, que resulta de la apropiación simbólico-expresiva del espacio(Giménez, 2000:27), una de sus dimensiones es la de ser apropiado subjetivamente como objeto de representación y de apego afectivo $\mathrm{y}$, sobre todo, como símbolo de pertenencia socio-territorial. Si consideramos además que los territorios internos perduran, como afirma Gilberto Giménez, aunque transformados bajo la presión homologante de la globalización(Ibid, 33), la persistencia de identidades socio-territoriales en espacios como este existe, aunque bajo formas modificadas y según configuraciones nuevas, articuladas con muchas otras no territoriales, como la identidad religiosa, política, ocupacional, generacional, etc..

Territorializar el patrimonio es destacar que este es expresión de una comunidad en particular, arraigado al suelo natal, ya que el territorio "no es un espacio sobre el cual transcurre la vida social(Giménez,cit. en Guerrero, 2005:s/n )", el territorio es considerado "artífice" de esa realidad, "históricamente construido y vivido, que incluye determinados procesos sociales y culturales que intervienen en la experiencia de vida de sus habitantes". De acuerdo con el mismo autor, la reactivación de identidades en un contexto globalizado como el de estudio, recurre a la tradición como herramienta para enfrentarla en un espacio conformado por fuerzas que en sentido contrario tratan de socavar sus expresiones.

Si bien existen distintos tipos de identidades en la comunidad sanandreseña, nos referirnos a las identidades histórico-patrimoniales, relacionadas por acontecimientos pasados importantes para la colectividad y con un patrimonio socio-cultural y a las identidades vividas, reflejo de la vida cotidiana y del modo de vida actual del lugar, que podrán reactivarse y estimularán la solidaridad regional, como producto del orgullo de pertenencia y apego a la región(Giménez, 2000:40). La identidad será el recurso que como dice Melé, se expresará durante las situaciones de conflicto derivadas de los procesos inmersos en el contexto actual, porque la permanencia en el lugar y el patrimonio están en juego, ahora en territorio urbano, manifestando en las apropiaciones, voluntades de apropiaciones y oposiciones entre usos, las representaciones e ideas sobre lo que el 
territorio común debe ser. En este sentido, la participación de las autoridades locales con acciones que apoyen además de la economía, a la identidad local, resulta importante para conseguir la participación comunitaria en estos procesos, con proyectos propios y una representación en las negociaciones con los actores externos, para que beneficiaran a toda la población.

Los procesos que problematizan actualmente a este espacio y a la comunidad originaria en un momento de grave crisis económica y urbanización acelerada, se encuentran vinculados a esta acción, que se aplica desde las autoridades federales y locales, violentando las relaciones socioespaciales, la economía y la política, con efectos en las prácticas culturales de los habitantes de San Andrés, observables en tensiones, controversias, contradicciones y en ocasiones a través de conflictos abiertos al interior y exterior, interpretándose tales acciones como políticas partidistas, que denotan una falta de interés en la participación comunitaria y el beneficio social de las mayorías. La redefinición socioespacial de este sitio, así como la construcción de la relación vecinos/originarios, son procesos adicionales con gran peso social que se derivan de la urbanización del lugar, sin que a la fecha sea observado, considerado o expuesto en la región para su investigación y estudio.

Consideramos que la adhesión de poblados prehispánicos, de origen indígena (actualmente mestizos), a las grandes metrópolis constituye un proceso que a pesar de haber sido analizado insistentemente por la antropología, por su frecuencia y actual vinculación a procesos de la economía global, presenta especificidades y nuevas formas de inserción que deben ser estudiadas en un marco analítico más amplio y acucioso que de acuerdo con Wacquant, inscriban la revitalización de distritos adentro de la estructura social urbana completa, llevándolo más allá del estudio de las reglas de la ciudad a un más alto precio teórico y que ponga en el centro al estado como generador de desigualdades económicas y sociales(Wacquant, 2008:203). La gentrificación y patrimonialización se presentan en este caso como procesos renovados de inducción de cambios y efectos de recomposición social, que representan momentos decisivos para la prueba de teorías que demuestren su efectividad y sean actualizadas y sobre todo, para insistir en la exposición de problemas sociales irresueltos. 


\section{B I B L I O G R A F Í A}

1. Améndola G.(2000), La Ciudad Postmoderna, p. 124, Celeste Ediciones, Madrid, citado en García Herrera Luz Marina, Elitización: Propuesta en español para el término Gentrificación, en Biblio 3W, RevistaBibliográfica de Geografía y Ciencias Sociales, Universidad de Barcelona, Rescatado el 26 de marzo de 2009 en: www.ub.es/geocrit/b3w-332.htm

2. Alonso Zaldívar, C. y Castells(2000), M., España, fin de Siglo,1992, citado en Jordi Borja y Manuel Castells, Local y Global, la gestión de las ciudades en la era de la información, Ed. Taurus, México

3. Authier, Jean-Yves y Bidou-Zachariasen Catherine(2008), La cuestión de la gentrificación urbana(La question de la gentrification urbaine), en Revista Espacios y Sociedades(Espaces et societés), 132-133, No. 1-2/2008, Ed. Erés, Francia

4. Bonfil, Batalla(1973), Cholula La Ciudad Sagrada en la Era Industrial(1973), Ed. UAP, México

5. Bourdieu, Pierre( 1999 ), La Miseria del Mundo, Los efectos del lugar, Ed. FCE, Argentina

6. Borja, Jordi y Castells(2002), Manuel, Local y Global. La gestión de las ciudades en la era de la información, Ed. Taurus, México

7. Brockerhoff, Martin(1997), Review of The New Urban Frontier: Gentrification and the Revanchist City by Neil Smith, Population and Development Review, Vol. 23 No. 2,(June, 1997), P. 441, Ed. Population Council, Stable URL: Rescatado el 25 de marzo de 2009 en: http://www.jstor.org/stable/2137563

8. Butler, Tim(s/f), Living in the Bubble, gentrification and its others in North London, Rescatado el 28 de marzo de 2009 en:

cus. sagepub.com/search.cgi?journal $=\mathrm{X} \&$ query=gentrification 
9. Castells, Manuel(1981), Capital Multinacional, Estados Nacionales, Comunidades Locales, pp. 20-21, Ed. S: XXI, México.

- Castells, Manuel(1999), La Era de la Información, Estado, Sociedad y Cultura. El poder de la Identidad, Vol. II, p. 393, Ed. S. XXI, México

10. Corsin, Jiménez, A. (2001), The Becoming of Space: A Geography of Liminal Practices of the city of Antofagasta, Chile, Tesis de doctorado en antropología, Universidad de Oxford

- (2003), On Space as a Capacity, J. Roy, Anthrop., Inst., No.9, p 137-153

11. Díaz Orueta Fernando(2006), Globalización, espacio urbano y fragmentación social. Los Muros de la ciudad, en Ponce, Herrero Gabino, La ciudad fragmentada: nuevas formas de hábitat, Ed. Universidad de Alicante, España

12. Duhau, Emilio y Giglia, Ángela(2008), Las reglas del desorden. Habitar la metrópoli, P. 16, Ed. S XXI/UAM, México

- Conflictos por el espacio y orden urbano(2004), Revista Estudios Demográficos y Urbanos, Vol. 19, Núm. 2(56), México

13. Fuente Información de San Andrés Cholula, Rescatado el 17 de marzo de 2009 en: www.puebla.mx.com

14 García Canclini Néstor(1987), ¿Quiénes usan el patrimonio? Políticas culturales y participación social, Antropología, boletín oficial del INAH, nueva época, Nos., 15-16, julio-octubre, México

- Introducción(1999), en Signorelli, Amalia, Antropología Urbana, Ed. AnthroposUAM, España

15 García Herrera Luz Marina(2001), Elitización: Propuesta en español para el término Gentrificación, en Biblio 3W, Revista Bibliográfica de Geografía y Ciencias Sociales, Universidad de Barcelona, Vol. VI, No. 332, 5 de diciembre de 2001, Rescatado el 9 de abril de 2009 en: www.ub.es/geocrit/b3w-332.htm 
16 Giglia, Angela y otros(2007), ¿Adóndeva la antropología?, Ed. UAM/JP/Tecnigraf, México

17 Giménez, Gilberto(2000), Territorio, cultura e identidades. La Región Sociocultural, en Rocío Rosales Ortega(Coord.) Globalización y regiones en México, Ed. UNAM/Porrúa, México.

20. Gluckman, Max(1958), Análisis de una situación social en Zululandia moderna, La organización social, Ensayo, Rescatado el 14 de noviembre de 2008 en:

www.uam-antropología.info/web/articulos/gluckman1958.pdf

18 Guerrero Valdebenito, Rosa María(2005), en Identidades Territoriales y Patrimonio Cultural: La apropiación del patrimonio mundial en los espacios urbanos locales, F@ro, Revista teórica del Departamento de Ciencias de la Comunicación 1-2, 289-303, Universidad de Playa Ancha, Chile, Rescatado el 31 de marzo de 2009 en: web.upla.cl/revistafaro/n2/02_guerrero.htm

19 Harvey, David(1990), The condition of Postmodernity, pp. 226, Blackwell Publishers Ltd, U.S.A.

20 Leal Martínez, Alejandra(2007), Peligro, proximidad y diferencia: negociar fronteras en el Centro Histórico de la Ciudad de México, Revista Alteridades 2007, Año 17, Núm. 34, Págs. 27-38, Ed. UAM, México

21 Licona, Ernesto, Habitar y significar la ciudad(2007), Ed. CONACYT/ UAM, México, 2007

22 Melé, Patrice(1994), Puebla: Urbanización y Políticas urbanas, Ed. BUAP/UAM, México, 1994

Sacralizar el espacio urbano: el centro de las ciudades mexicanas como patrimonio mundial no renovable(1998), Revista Alteridades, 1998, 8 (1\&), Págs. 11-26, Universidad Autónoma Metropolitana, Unidad Iztapalapa, México

Conflictos, territorio y acción pública en México (Conflicts, territoire et action publique au Mexique), Proyecto de investigación inscrito en el Proyecto Colectivo: El territorio y 
sus construcciones, iniciado por tres laboratorios: Centro de Estudios

Transdisciplinarios de Sociología, Antropología e Historia de I'EHES(Paris, Fr.), el

Colegio de San Luis(S.L.P., México) y el equipo Ciudad, sociedad y territorio de I'UMR CITERES(Tours, Fr.),

- La Producción del patrimonio urbano(2006), Ed. CIESAS, México

23 Melé Patrice, y Bassols, Mario(coord.)(2001), Medio Ambiente, ciudad y orden jurídico, Ed. Miguel Angel Porrúa y U.A.M.I., México

24 Nates, Cruz, Beatriz(2008), Procesos de gentrificación en lugares rururbanos:Presupuestos conceptuales para su estudio en Colombia, en Revista de Antropología y Sociología Virajes, Núm. 10, Dic. 2008, Universidad de Caldas, Colombia. Recuperado el 17 de julio en:

virajes.ucaldas.edu.co/index.php?option

25 Nivón, Eduardo(1998), De periferias y suburbios, Territorio y relaciones culturales en los márgenes de la ciudad, Centralidad y Periferia en la cultura urbana, en García Canclini Néstor (coord.) et al.,Cultura y Comunicación en la ciudad de México, pp. 212-213, Vol. 1, Ed. UAM-Iztapalapa/Grijalbo, México

26 Pareto, V.(1979), Compendium of General Sociology, p. 273-279, University of Minnesota Press, García Herrera Luz Marina, Elitización: Propuesta en español para el término Gentrificación, en Biblio 3W, Revista Bibliográfica de Geografía y Ciencias Sociales, Universidad de Barcelona, Rescatado el 25 de marzo en: www.ub.es/geocrit/b3w-332.htm

27 Phillips, Martin( 2008 ), Rural gentrification- SciTopics, Recuperado el 17 de julio en: http://www.scitopics.com/Rural_gentrification.html

- Rural gentrification and the processes of class colonization(1993), in Journal of Rural Studies. Recuperado el 18 de Julio en:

http://www.sciencedirect.com/science?

28 Portal, Ariosa, María Ana(1997), Ciudadanos desde el Pueblo, p.p. 44-45, CONACYT/UAM Iztapalala, México. 
- Portal, Ariosa, María Ana(coord.)(2007), Espacios públicos y prácticas metropolitanas, Consejo Nacional de Ciencia y Tecnología(CONACYT)/Universidad Autónoma Metropolitana(UAM), México

29 Reguillo, Rossana(2004), The Oracle in the City: Beliefs, practices and symbolic geographies" en Social Text, año 22, núm. 4. P.p..35-46

30 Rosas Mantecón, Ana(2005), Las Disputas por el Patrimonio, Transformaciones analíticas y contextuales de la problemática patrimonial en México, en La antropología urbana en México, García Canclini, Néstor(Coord), UAM, CONACYT, FCE, México

31 Sabatini, Francisco, Entrevista por Antonia Campos, Rescatado el 24 de marzo de 2009 en: http://www.prourbana.cl/upload/FSabatini/PMontt.pdf

32 Safa Barraza Patricia(2001), Vecinos y vecindarios en la ciudad de México, Ed. CIESAS/Miguel A. Porrúa, México, 2001

33 Sargatal Ma. Alba(2001), Gentrificación e inmigración en los centros históricos: el caso del Barrio del Raval en Barcelona, Scripta Nova, Revista electrónica de Geografia y Ciencias Sociales, Universidad de Barcelona No. 94(66), 1 de agosto de 2001, Rescatado el 22 de marzo de 2009 en: www.ub.es/geocrit/sn-94-66.htm

34 Seppanen, Maaria(2003), Historia local y patrimonio mundial. Ciudad letrada, arcadia nacional y el centro histórico de Lima, Ponencia presentada en el $50^{\circ}$. Congreso Internacional de Americanistas, Varsovia 10-14 de julio de 2000, publicado en Anuario Americanista Europeo, No. 1, pp. 107-120, Rescatado el 20 de marzo de 2009, en www.red-redial.net/doc/Partiel_(Seppanen_107_120).pdf

35 Smith Neil(2002), La urbanización del neoliberalismo: debates teóricos. Nuevo globalismo, nuevo urbanismo: Gentrificación, como estrategia global urbana, en Antipode, A radial Journal of Geography, Volúmen 34, Issue 3,pages 427-450, Publicado en línea el 16 de diciembre de 2002( New globalism, new urbanism), Rescatado el 21 de junio de 2009, en http://www.antipode-online.net/abstract.asp?vid $=34 \&$ iid $=3 \&$ aid $=4 \& s=0$ 
36 Trom, Danny(2001), De la réfutation de l'effet Nimby consideréé comme une pratique militante, citado en Melé, Patrice, y Bassols, Mario(coord.), Medio Ambiente, ciudad y orden jurídico, pp. 15-18, Ed. Miguel Angel Porrúa y U.A.M.I., México, 2001

37 Turner, Victor(1974), Dramas, Fields, and Metaphors. Symbolic Action in Human Society, Nueva York, Cornell University Press, 1974, pp. 23-59, en Geist, Ingrid(2002), Antropología del Ritual, INAH/ENAH, México

38 Vergara, Abilio(2005), Diario de Campo, Antropología del espacio público: La Plaza, suplemento Núm. 34, julio 2005, México

39 Wacquant, Loic(2001), Parias Urbanos, Marginalidad en la ciudad a comienzos del milenio, Ed. Manantial, Argentina

- $\quad$ 2008, Reubicando a la Gentrificación: La clase trabajadora, la ciencia y el estado en la investigación urbana reciente, International Journal of Urban and Regional Research, 198-201, The Author Journal Compilation (C) 2008 Joint Editors and Blackwell Publishing Ltd.

Recuperado el 20 de marzo de 2009 en: www3.interscience.wiley.com/journal/119403667/abstract

40 Wetzel, Tom(2004), ¿Qué es la gentrificación?, Rescatado el 21 de junio de 2009 en: www.worldarchitecture.org/theory-issues/?position=detail \&no=285 
A NEXOS 


\section{ANEXO: E N T R E V I S T A S}

\section{- PlÁtICA CON ADMINISTRAdOR DE CONTAINER CITY}

Fecha: Marzo, 2009

Lugar: San Andrés Cholula

Un hombre de edad mayor, con acento extranjero, al que llaman "el Santa Clos", rectifica cuando le pregunto acerca de si él es el creador de este concepto y se presenta como "administrador" de este espacio. En una breve plática narra el origen de este lugar:

"Container City", no es un concepto original, existe en otras capitales del primer mundo: Inglaterra, Alemania?, Nueva York. Se crea inicialmente(hace dos años?) para uso habitacional por gente joven, por ser un concepto funcional que permite cierta movilidad, bajo costo, adaptabilidad en terrenos de extensión reducida, etc.. sin embargo no funcionó en San Andrés de esta manera y después de un tiempo decidieron volverlo espacio comercial y de entretenimiento nocturno. Acepta haber cometido varios errores que tuvieron efectos económicos adversos, en un comienzo, y que más tarde se corrigieron al convertirlo en centro comercial. Se encuentra en la primera etapa, la que sigue, la 2, permitirá aumentar beneficios y éxito, sin embargo han preferido irse más lento para contar con una firmeza económica.

¿Está dirigido a jóvenes, estudiantes?, NO, usted bien sabe que uno no puede vivir de los estudiantes, de la gente joven... buscamos y viene toda clase de público, por eso hay restaurantes como "Flavor" que tiene una cocina deliciosa y pan excelente que me está haciendo aumentar de peso"

El está de acuerdo en llamarlo plaza comercial, que se presenta en un concepto distinto al tradicional. Tiene a dos sobrinos, quiénes han sido los creadores de este proyecto en San Andrés Cholula, uno de ellos es diseñador gráfico. Los containers permiten colocarse en diferentes direcciones y su amplitud depende de la solicitud del cliente, ya que pueden colocarse dos unidos para aumentar el espacio. Tienen una extensión hasta de $30 \mathrm{~m}$ de largo por 3.5 de ancho, la altura va de 2.5 a $3 \mathrm{~m}$

Ante la pregunta de porqué eligieron a San Andrés Cholula para instalarlo, responde que "Cholula les gustó para ello", añadiendo que el proyecto les ha encantado a mucha gente que actualmente les están copiando y llevando a otros lugares también de Cholula: "la gente viene y está tomando notas"

Tiene mucho más vida durante la noche, de las 9 a la 1 de la mañana que es cuando varios restaurantes cierran, permaneciendo los bares abiertos hasta las 3 a.m., de acuerdo a la información de dos trabajadores de este lugar. Según el administrador, están trabajando para que aumenten las visitas y consumidores, durante el día, por lo que han aceptado la instalación de algunos negocios como salón de belleza, lectura de Tarot, próximamente Pizzerías, restaurantes de comida turca, y desde luego, las boutiques.

Tienen una página web: www.containercity, en la cual aparece toda la información que uno se interese conocer. Asímismo habló de este concepto, como centro habitacional, que en Monterrey se ha realizado y buscar la página: www.pfnc. com.mx (pfnc: Por Fin Nuestra Casa) pues al parecer allá ha tenido éxito.

Próximamente se instalarán en otros dos containers, actualmente vacíos, algunas tiendas de cadenas comerciales poblanas como Mister Tennis y otras. Las dos áreas de estacionamiento se están adoquinando para ofrecer más comodidad, libre de polvo a los clientes.

Sugirió tener una plática-entrevista con uno de los jóvenes creadores, durante la semana, por la mañana, quién podrá hablar ampliamente de esta idea.

$\infty$

\section{- ENTREVISTA A EMPRESARIO IMPLANTADOR DEL PROYECTO “CONTAINER CITY" EN SAN ANDRÉS CHOLULA.}

Fecha: Marzo, 2009

Lugar: San Andrés, Cholula

Edad: 40 años, aprox.(origen Libanés)

Observaciones: No saqué cita, pero aceptó tener una plática de 10 min. Máximo en ese momento, según lo expresó: para "quitarse ese peso de encima"

Acerca de los antecedentes del proyecto:

C: Me he enterado que este proyecto inicialmente fue creado en Inglaterra, pero para uso habitacional..

G: No, no, esto es único, es original, no hay en el mundo nada así, se trata de uso habitacional y comercial, comercio y habitación.

C: ¿Qué idea lo animó a hacerlo de esta forma?

G: Hacer algo creativo más económico, algo que detone la zona económicamente.

C: ¿porqué acá?

G: No me lo va a creer, yo vivo por aquí cerquita, entonces pasé, ví el terreno muy bonito, en un bonito lugar....Considero importante que en todas las zonas como Cholula, el turista viene y se va, pero es importante hacerlo que regrese. Entonces cada país, en España y otros, está empeñado en lograr eso... hacer que el turista regrese, hacer ciudades muy vivas $;$ C: ¿considera usted que eso es lo que necesita este lugar?

G: Sí claro 
C: Pero inicialmente tengo entendido que ustedes entraron únicamente con uso habitacional ¿no?

G: Si pero....en una segunda etapa va a ser así

C: Esta segunda etapa será en este mismo lugar?

G: Sí

C: Pero, lo veo casi lleno..

G: Si pero solo serán algunos containers para habitación

$\mathrm{C}$ : ¿renta o venta?

G: No, solo renta

C: Y ¿que tan cara es la renta en comparación con las casas convencionales de acá?

G: No, es un poco más cara

$\mathrm{C}$ : entonces, ¿qué ventaja ofrecen ustedes?

G: Definitivamente, el concepto: "vivir en un container", para lo cual se necesita cierto tipo de gente....

C: como artistas, diseñadorres, que además tengan recursos para pagarlo ¿no?

G: Exactamente

C: ¿Cuánto tiempo llevan acá?

G: Un año

C: Y ¿cuál ha sido la respuesta?

G: Pues ahí vamos...nuestros inquilinos son gente joven, entonces no tienen experiencia en negocios y hay que guiarlos, empujarlos, asesorarlos. Necesitamos negocios como "Café Punta del Cielo", que ya son más expertos, más maduros en negocios.

C: ¿Cuál ha sido la mayor complicación?

G: Pelear con el Ayuntamiento, que complica, obstaculiza, cobra, no apoya...pero somos el único punto que está desarrollando el turismo...

C: Entonces ¿ustedes se consideran más que otra cosa un proyecto turístico? G: Sí, próximamente el Turibús que anda en Puebla, hará una parada aquí y también habrá una salida/llegada de autobús
México-Puebla-México, de Estrella Roja.

C: ¿Cuál es su perspectiva a futuro?

G: Eso me acaban de preguntar... Estructurar el container para "clonar" por otros lados

$C:$ ¿En donde sería?

G: Donde sea;

C: Y Complicaciones...¿ ¿cuáles han sido las más importantes?

G: Es un concepto juvenil y nuestros inquilinos son jóvenes inexpertos...

C: Y dígame, ¿lo consideran también como un espacio creativo, artístico, que de cabida a diseñadores y otros?

G: Inicialmente había talleres aquí abajo, era una "ciudad creativa", yo todavía tengo aquí en mi oficina mi taller de

diseño gráfico, pero no.....ahora buscamos que sea creativo y empresario

C: ¿quiénes son sus clientes? ¿vienen de Puebla?

G: No, también vienen del DF y del extranjero. Y ya nos están copiando la idea, sí, acá a la vuelta ya van a poner otro, allá por CU en Puebla, ya pusieron unos cuatro trailers(moviendo la cabeza)

Observaciones: Más tarde, al hablar con un empleado del mismo lugar, me entera que les está yendo tan bien a los dueños de este lugar, que ya están poniendo el otro a la vuelta. O sea, se trata del mismo empresario.

$\infty$

\author{
- PLÁTICA CON "YUPPIE”(Dueño de Bar en Container City) \\ Fecha: Febrero de 2009. \\ Lugar: San Andrés Cholula
}

Joven de 27 años, aprox., soltero, con estudios de Lic. En Turismo, en Guadalajara.

Originario de Culiacán, ha radicado en Celaya, Gto., Guadalajara, Jal., y Playa del Carmen, Q.R.. Actualmente es socio del bar "Siete Santos" que forma parte de Container City. Se trata de un bar de corte moderno que ocupa tres containers
con planta baja y terraza.

C: ¿Cómo llegas a este lugar y se engancha en este negocio?

Fue invitado por "Jack" a ser socio de este bar y se viene de Playa del Carmen desde hace 2 meses a radicar a San Andrés y hacerse cargo del bar. Además de esto, su novia es de Puebla, ha radicado los últimos años en San Andrés, la conoce en Playa del Carmen y decide venirse con ella. Tienen una relación de un año y viven juntos en un departamento a dos, tres
cuadras de CC.

C: ¿Qué es lo mejor, lo más rescatable de este proyecto? 
Lo más rescatable es que todo es lo "reciclado", aprovechando material de deshecho y eso es muy bueno. Ya están poniendo otro igual allá a dos cuadras de aquí, tal vez solo sea para habitación, porque en un principio aquí fue así. además algunos se quedan "ciudad" que se está renovando constantemente, unos vienen y se van y luego llegan otros, hay bastante dineroi

$\mathrm{C}$ : ¿porqué ciudad?

Porque si digo "pueblo" ella se enoja(je,je), no pero además no tiene más de 20,000 habitantes no? No se le puede decir
ciudad

C: Pero de alguna manera ya es parte de una gran ciudad, es zona conurbada.

Exactamente. Ella es de Puebla

Ella: Sí pero no me gusta. Si como que son más cuadrados.

Ella: Son más "borregueados". Ël no conoce Puebla, ni el zócalo

Yo odio la ciudad, rehúllo a lo urbano, solo vamos a visitar a la suegra.

$\mathrm{C}$ : ¿quiénes son sus clientes?

Tenemos a mucha gente de fuera: de Veracrúz, Oaxaca, del DF y también vienen de Puebla. Lo chido de este pueblo es que se conserva así, uno encuentra todavía, caballo, perros, muchos perros y tienes la diversión y ofreces algo atractivo
como esto.

Esta es una plaza comercial, pero no con sus escaleras eléctricas y demás, aquí es más ligero y además cada tienda es original, ofrece algo diferente. Por ejemplo hay una que todo está hecho con reciclado. Aquí es algo alternativo...

$\mathrm{C}$ : Y tienen restaurantes, próximamente va a haber comida turca.

¿dónde?

C: Allá en un local del fondo

Ah, órale que bien, ¡Mac-Turc... i

C: Si va bien, también va a haber una salida de un autobús de Estrella Roja, que va air al DF

Qué bien, eso si se va a poner mejor, porque no siempre se puede manejar.

$C$ : Y dicen que el turibús va a hacer una parada acá justamente

No hombre...eso si va estar mejor... dicen que el concepto es de origen europeo o algo así,

C: si en Inglaterra, Holanda y España. También en NY

$\mathrm{Si}$, si, me parece más cercano a lo que hay en NY, eso me gusta.

C: ¿Y cuánto pagan de renta?

Siete mil pesos por container y tenemos $3 \ldots$,

Es que proyectos como estos, jalan mucho dinero, después que los encarrilaste, se sientan y ahí está el problema. Ojalá
que corrijan lo de la luz..

que corrijan lo de la luz..

Pues en las noches se va la luz, cuando todo esto está más movido. Dicen que porque no se hizo bien la instalación,

entonces me dijeron que tal vez hay que poner un transformador que aguante y cuesta como 200000 , y los de la Cia. De
Luz se quedan con él...

C: ¿Acerca del nombre "siete santos", tiene alguna relación con alguna leyenda de Cholula?

No, yo alguna vez leí que era una leyenda de Escandinavia o algo así: 7 ascetas que deciden renunciar a sus bienes y se y en ese momento mueren.

C: ¿Quién lo decoró?

El chavo de la boutique de allá,

$\mathrm{C}$ : ¿tienen internet?

$\mathrm{Si}$, en todas partes hay internet. Es de Punta del Cielo y ellos nos dieron a todos su clave, pero creo que debía haber una

red para todos, porque eso sería muy bueno para aprovecharlo y jalar más gente. Lo voy a preguntar.
C: ¿y cada local tiene su baño?

No, bueno nosotros sí, pero hay un baño común allá arriba y está muy bien..

música?

Pues ponemos tranquila como ahorita, también ponemos "techno" y "beat", aquí lo fuerte es la "techno". Pero procuramos no ponerla durante mucho tiempo porque la gente se espanta y se va... se harta

Ahora los miércoles van a ser de "funk" y las damas van a ser gratis.... Vamos a promoverlo.

$\infty$

\section{- PLÁTICA CON HIPPIES}

Fecha: Marzo de 2009.

Lugar: San Andrés Cholula

Jóven de 27 años, mamá de 3 hijos de 7, 5, 2 años. Su pareja y padre de sus hijos es artesano. Se conocieron en Puebla y ninguno de los dos tiene estudios universitarios. Ella pinta al óleo y vende sus cuadros en ocasiones, también se dedica a
la artesanía. 
Jóven de 25 años, mamá de dos hijos de 6 y 2 años. Su pareja y padre de sus hijos es artesano y vendedor de otros la calle. Se conocieron en Puebla cuando ella estudil vender. Los dos trabajan la artesanía generalmente tendiéndose en la calle. Se conocieron en Puebla cuando ella estudiaba el segundo semestre de antropología social y a partir de entonces
viven juntos. Jóven de 28 años, de origen español. Es originaria del país Vasco y vino hace un año a estudiar durante un año a la UDLA un la facultad de administración. Ahora viene como visitante por un mes, porque San Andrés le gustó mucho. Viene por

Las tres esue durante la fiesta del Equinoccio de Primavera que se celebró alrededor de la pirámide el día 21 de marzo. a su alrededor jugando con es un espacio que el Ayuntamiento de San Andrés les rentó por 15.00. Los niños permanecían La opinión que tienen de San Andrés:

Les gusta por ser más tranquilo que Puebla. En el caso de las dos primeras, la decisión de venirse a vivir a San Andrés, fue tomada repentinamente, en cuanto uno de ellos encontró una casa de 1,500.00 con un patio común que les pareció
atractivo para rentar y compartir las dos familias.

Se han cambiado varias veces en los tres años que llevan viviendo en San Andrés, aunque las razones no las expresaron directamente, comentó una de ellas que los caseros que les han tocado no siempre han sido "amables", en una ocasión no viejito que platicaba mucho con su uijicamente por haber perforado con algunos clavos la pared. En otra recuerda a un tipo, son desconfiados, en general encuentra que, aunque hay gente de todo vigilada, pero dice no haber tenidos preguntas para saber de dónde vienen, qué hacen, etc.. En ocasiones se ha sentido enojón. Próximamente se piensa regresar a enfrentamiento con nadie. En cambio su esposo sí porque según dijo es más están de un nivel muy mucho la localivel muy bajo aunque baratas, pues paga 350.00 mensuales por el preescolar de su hijo. Dijo no conocer Le sale de vez en cuando y tiene poco trato con la gente.

La otra joven dijo sentirse mal con la gente, refiriendo algún incidente con una vecina a quien le quiso vender una carriola y reaccionó violentamente ante el precio propuesto. En sus recorridos por el pueblo elige las calles por donde pasar y señoras muy desconfiadas ende siente que no es bien vista. En la escuela pública adonde lleva a sus hijas, nota a las allá de lo necesario.

La joven extranjera, dijo no haberse sentido mal vista o agredida por la gente de la comunidad, aunque en una ocasión si le han gritado: "ivete gringa de mierda;". De recién llegada, en donde se sintió a disgusto e incómoda fue en la UDLA y quería regresarse a su país. Le parece que con solo cruzar la malla de acceso al campus, uno entra en otro mundo. Casi no tiene amigos ni amigas, pero en ocasiones si ha entrado a algunos "antros" que además le han impactado por su estilo y dijo no haber visto nada así en su país, pero no está de acuerdo en que den preferencia para entrar a los extranjeros y hagan esperar a los mexicanos, como lo presenció en El Tigre. También está asombrada por ver la discriminación entre mexicanos, que utilizan la palabra "indio" para ofenderse. Le gusta San Andrés porque es mucha más tranquilo y le agrada la gente que también lo es, a diferencia de la gente tan "estresada" que hay en su tierra, en busca de trabajo, de casa, que ahora ya no se puede comprar por los altos costos y quienes compraron dos o tres se han endeudado con los bancos a quienes no pueden pagar. En estos momentos dijo, hay muchas casas vacías, porque la gente las ha abandonado.

\section{- ENTREVISTA A AVECINDADA DE "ENCLAVE" \\ Fecha: Marzo, 2009}

Lugar: San Andrés, Cholula

Aunque se trata de una casa habitación y no en conjunto residencial, además ubicada en el centro de San Andrés, a dos calles del zócalo, considero que el estilo de vida de esta familia es en las mismas condiciones

Casa bardeada a una altura de $3 \mathrm{~m}$, malla eléctrica?, portón eléctrico, calle de poco tráfico, junto a propiedades de grandes dimensiones como Una escuela Montessori, frente al balneario ....., cuenta con jardín interior?.......si. Son $500 \mathrm{~m}$. de
terreno y 600 de construcción.

Tipo de familia: 4 miembros, de $65,57,30$ y 28

Papá e hijos: Arquitectos Mamá: hogar

Preguntas:

Años de vivir en San Andrés: 15 años

Cómo llegaron: Estuvimos viviendo 12 años en la zona residencial de la UDLA, mi esposo trabajaba allá y hace tres años que se salió, decidimos buscar un lugar acá para construir nuestra casa.

Déjame decirte que vivir en la UDLA es vivir en una burbuja, porque alli tienes de todo, hay tiendas, bancos, cine, teatro, etc., no necesitas salir para nada, así que poco se interactúa con la gente y el lugar.

San Andrés, no sé que tiene, pero tiene algo que hace que muchos extranjeros vivan aquí, les guste y entonces tu encuentras muchos mundos. 
Cuando compramos el terreno, lo encontré rapidísimo, el mismo día que salió el anuncio en el periódico, llegamos y nos gustó la ubicación. Me acompañó mi hijo y antes de que llegara la señora que nos lo vendió me dijo: mamá este no ha de
ser el terreno porque está muy barato $i$ pero no, si era.

Una vez que se cerró el trato, mi esposo y mis hijos se pudieron a hacer el plano, cada quien se diseñó su propio espacio de acuerdo a sus necesidades y gustos. Cuando fuimos a sacar el permiso para construir, nos dijeron que esta es "zona Residencial" y que no permiten que se construyan casas de más de dos pisos. Alrededor de la pirámide, es zona federal, allá nos ofrecieron también un terreno, junto al hotel, pero no se puede construir más de a nivel de suelo, el INAH no lo permite, pero imagínate ¡enfrente de la pirámide;

Cómo me siento? Bien pero lo que no me gustó y que no me imaginaba era la contaminación del ruido. Porque aquí todo el año los cuetes, a veces es durante toda la noche i y son unos cuetones que no te dejan dormir, o bien, te despiertan pero sobre saltado, es horrible. Después, ya ves que estamos enfrente del balneario, bueno, pues toda la mañana ponen la música a todo volumen y qué música y yo digo pues que no pueden escucharla bajito? Porqué tiene que ser tan alto Una vez un señor de acá, de San Andrés me dijo: mire señora, le aseguro que esto no va a dilatar más de diez años. En diez años le aseguro que la gente tendrá que dejar de hacer eso, porque es molesto para las personas que llegan de otro
lado y cada vez llegan más...

Otra cosa que me desconcertó fue que yo siempre adondequiera que he vivido siempre ha sido con vigilancia, entonces el darme cuenta de que ahora nuestra casa daba a la calle, no... me pasé 15 días sin dormir, te lo juro, hasta que mis hijos me

Otra cosa es el servicio de limpia. En la administración anterior, el presidente municipal contrataba a personas de la tercera edad para que anduvieran barriendo las calles y todo estba muy limpio. En cambio ahora, los niños pasan y van tirando papeles y las mamás no les dicen nada o les dicen: tíralo ahí... No se si has visto que pusieron una escuelita en la otra calle, bueno, pues pasan todos los días las mamá con sus hijos en los triciclos o bicicletas y van tirando basura i el otro día me dejaron un pañal acá afuera. Y ya les he dicho, oye mi amor, no tires basuras porque se ve muy feo, por favor. Pero tengo ganas de ir a hablar con el presidente y decirle que ponga ese servicio otra vez, o con la directora de la escuela y decirle que ponga carteles o bien yo los hago, les llevo bolsas de basura o yo que se, pero definitivamente hay que trabajar
con los adultos.

Una vez aquí junto el señor que cuida la escuela, se puso a quemar basura, entonces fui a verlo y le dije, no sea malo mi casa mire como va a quedar, y como es blanca todo este humo la va a ensuciar, si quiere, le traigo unas bolsas grandes de basura, le dejo un paquete, para que ahí la vaya echando pero no la queme..... me dijo, si tiene usted razón señora. Entonces yo creo que lo que hace falta es ... hablar con la gente

Aquí enfrente, el balneario, es un lugar muy agradable, pues todos los fines de semana se llena y la gente mete vasos y bolsas de plástico en la malla de alambre. Me ha tocado ver que la gente pasa y las camionetas repartidoras de productos, se detienen, a ver a las muchachas, y bueno que hagan lo que quieran pero he pensado en ir a hablar con los encargados y decirles que les regalo unas bugambilias, para que se siembren en toda la malla y eso se tupa de colores, imagínate que bonito se vería, muy agradable. Entonces como lo.riegan mucho y ya viene la temporada de aguas..entonces sería
adecuado.

Ahorita por ejemplo ve... qué tranquilidad...

No se si has visto el mercado de comidas de aquí a la vuelta, es algo horrible, son de esas cosas que no entiendo que pasa por la cabeza de los políticos, pero definitivamente no sé porque los trajo y dejo poner aquí. El año pasado en la época de lluvias, todas las lonas se les vinieron encima, tenían que salir corriendo cuando empezaba a llover. Esta todo improvisado, dejan un basurero, bueno...

Otra cosa es que cuando tienen sus fiestas, a ellos les vale, cierran la calle y no importa que tu tengas que salir, alguna emergencia o algo, además ponen unas bocinotas y una música que no se ... porque no se conforman con que la escuchen
los de la fiesta, sino todo el mundo..

C: ¿pasan a pedirte cooperación para las fiestas?

Solo en una ocasión pasaron y les di 50 pesos, es la única ...

Lo de los cuetes, Te decía que el rector habló varias veces con diferentes presidentes y le decían que de verdad ellos estaban totalmente de acuerdo en que es algo muy molesto, pero que son como usos y costumbres. Porque ellos establecieron la costumbre que así fuera, te digo.. los años, el tiempo, la economía, a lo mejor modifique...porque... parece competencia oye... traer al grupo más escandaloso, las bocinas más grandes, pero quizás se modifique con el
tiempo y la llegada de más vecinos.

C: Porque los precios de los terrenos han subido, pero no se para la venta.

Sí, y la gente compra y compra.

C: Yo entro a la página de internet y aparecen muchas ofertas.

Si, nosotros tenemos dos casitas, pero están allá en San Pedro, por San Pablo Tecama, este.. ya junto están construyendo otra casita y así va a ser más fácil que se venda, porque hay crisis pero hay dinero, y la gente tiene dinero, en esta época de
crisis, compra más, porque el dinero les permite que les den más barato y...

C: Pues yo lo comparo con Puebla y San Andrés todavía representa la imagen de la tranquilidad, porque Puebla está... $\mathrm{Si}$, efectivamente. Fíjate que yo todos los días voy a ver a mis papás y no que cosa.. yo siento que la cantidad de autos es demasiado, me recuerda a México cuando empezó lo del día del no circula, que el parque vehicular aumentó tanto que lo que hizo fue se arrancara con eso. Es que aquí en Puebla ya hay horas en que vas a vuelta de rueda, mis papás viven en 
San José Vista Hermosa y ese tramo de ahí, qué tal?. Yo les digo saben que ya me voy me toca la salida del colegio, de los colegios, me voy a tardar mucho en salir. Y ahora como ya me regreso por esta vía, nueva, huy, estoy encantada. A ver, porque eso se va a llenar, si te fijas la cantidad de casas que están construyendo..

C: Y por allá están dando quizá más barato el metro que aquí en el centro?

Pues quiensabe fijate no tengo ni idea. Yo creo que depende de quien venda, es de acuerdo a la gente. Fíjate nosotros cuando compramos aquí la señora me vendía en 1,500 y lo compré a 1,000 y al mismo tiempo nosotros queríamos comprar exactamente en la calle donde vive Alma. Ves que en la esquina hay una casa grande, esa la restauró mi marido, comprar es dueño del terreno de junto, entonces queríamos comprar el terreno y estar junto a ellos. El caso es que cuando mi esposo habló con el dueño y le dijo: bueno yo estoy quería 1,0 en el terreno y le dijo: Yo no vendo, usted quiere comprar, y le dijo pues a ver si nos ponemos de acuerdo. Y usted si quier metro y mi marido le dijo: sabe que no considero que su terreno valga eso, y le dijo: Bueno, yo no vendo, usted si quiere comprar págueme lo que le estoy pidiendo... y evidentemente pues no, no lo compramos. Y al final de cuenta pues me gustó mucho más aquí y es que me gusta que estamos prácticamente en el centro.

C: No sé, pero me parece que es la parte como más ordenada.

Si exactamente, C: Quizás la cercanía a la pirámide y al propio centro, les va a convenir más porque lo van a mantener así. Claro, porque al ayuntamiento le conviene aunque sea mantener limpias dos o tres calles y conforme pase el tiempo..... Una amiga me decía una cosa: esto dentro de unos años va a ser como Coyoacán, que se fue transformando poco a poco hasta que llegó a ser y es de hecho una de las zonas más caras del Df

La pirámide,

C: Los proyectos turísticos, lo novedoso y las carencias de legislación, la 14

Lugares detonadores de beneficio económicos. ...

Yo creo que efectivamente, se vienen acercando poco a poco ese tipo de lugares,y creo que la gente no tiene conciencia de lo perturbador que puede resultar y lo grave que puede ser que tengas junto un lugar de esos..y desde que yo vivía en la universidad, no he entendido todavía, el que las autoridades permitan que se establezcan esa cantidad de lugares donde les venden a los muchachos alcohol y droga, cuando existe una legislación, que yo no se si sea del estado, pero que debería funcionar. Que no se permita que se establezca ningún tipo de estos negocios cerca de escuelas ni de universidades, y parece que es al revés. Porque si tu te fijas, de cualquiera de las puertas de la universidad, solo cruzas y te encuentras con calles de, zonas no diría yo de tolerancia pero finalmente son zonas de tolerancia de alcohol, droga... y ha ido aumentando, cada vez hay más antros, y como tu dices, creo que aquí en la 8 , ya he visto que hay uno, que tendrá unos dos o tres meses. Y qué sucede ...pues a mi me parece, que lo que está pasando es esto que nos está marcando como país y que es la corrupción. Porque, cada uno de estos establecimientos les están dando al ayuntamiento una cantidad de dinero porque les permita estar abiertos no?, que es otra de las cosas también, no cierran a las dos de la mañana, hay lugares que cierran a las cinco, cuatro, que eso también...o sea porqué? Porqué se permite? Pero yo también me cuestiono porqué la gente aquí, no los avecindados sino los que son originarios, han permitido eso, bueno pues porque ellos también son parte del negocio, o sea, rentan sus casas y reciben una buena cantidad por rentar esos espacios para lo que sea.....

C: Ya ves que sobre la 14, se construyeron varias residencias frente a la universidad, en la idea de llevar una vida ...

Plácida

C: que ahora están atrapadas por los antros,

Y no hay para donde porque la autoridad está totalmente coludidai.

C: No se si tu recuerdes que ha habido restricciones temporales, desde que estaba Bartlett, luego con Doger que puso el alcoholímetro.... se ha $\mathrm{n}$ repetido esos momentos... esas medidas te has enterado que efectivamente se hayan tomado y
mantenido por cuanto tiempo...

No, yo creo que cada X tiempo, dicen que lo van a hacer para que la gente se tranquilice, por ejemplo en tiempos electorales se dice que el nuevo ayuntamiento ahora si se va a encargar de que se cierren todos estos antros, que ya no vendan alcohol a los muchachos, ... no es cierto, no porque? Porque se han convertido en una mina de oro, entra dinero
para todos lados y ninguno quiere perder el negocio entonces..

Es como con lo de la droga, cuando yo leía sobre Colombia, yo decía hay, que nunca vaya a pasar eso aquí, y vé como estamos?...y todo porqué? Porque las autoridades están coludidas por un lado, reciben una cantidad de dinero increíble, y no lo quieren perder...Pero lo que no se dieron cuenta, yo creo, es en qué momento esto iba a tomar la dimensión que ha

C: yo veo también que se están implantando, otros, usos y modas, como lo de los tatuajes y espacios así para otros públicos. Esta entonces la comunidad, los estudiantes que les gusta vivir un poco más tranquilos, que por cierto, ahora veo

Sí hay muchos estudiantes y otras para jóvenes matrimonios que están comensando, que trabajan los dos, porque se ve que son casas que tienen vida por las noches..son como dormitorio, pero.. me gustó la idea porque no cambian ni modifican totalmente la zona, porque les decía yo a mis hijos, este tipo de construcción que se haga, no importa que no sean ni grandes casas ni grandes construcciones, pero que sean así, de ese nivel... porque de hecho aquí no puedes construir más de un piso..no, no ya me acordé hasta dos plantas, donde no puedes construir más que a nivel de planta baja es alrededor de la pirámide porque es área protegida y el INAH no lo permite. C: Otro cambio que he observado es la conversión de terrenos en fraccionamientos.... alrededor del centro. Porque además
veo que el ayuntamiento tiene ya mucho movimiento 
$\mathrm{Si}$, si y eso es por toda la zona de Angelópolis que tienen que venir a hacer aquí el pago de impuestos. Entonces, antes, te podías estacionar junto al parque, pero tiene como tres cuatro años que te tienes que estacionar varias cuadras adelante. Pero si, por las nuevas necesidades se está modificando esta parte, pero bueno, a ver que pasa...

C: ¿Qué te gustaría que pasara?

Pues, que hubiese ordenamiento.... En los servicios, este ... legislación, construcciones .. que ciertos usos y costumbres que "ellos" ya tienen muy arraigados, que no cambien en esencia, pero si que sea un poco más compatible la vida de unos y otros, porque finalmente está llegando mucha gente de fuera, pero yo quiero creer y pensar que la gente que llegue de fuera igual que respetar sus usos y costumbres, que aunque te incomoden ciertas cosas, que "ellos" también piensen un poco en los demás, y en que no pasaría nada si le bajan un poquito al volumen, que no pasaría nada si en lugar esos cuetonononones, que el festejo fuera el mismo pero a lo mejor con algo menos agresivo, que la hora de echar cuetes fuera dentro de un cierto horario, porque es a veces toda la noche, toda la noche, empiezan a las 11 de la noche y son las 7 de la mañana y no paran, te digo, afortunadamente no es toda la semana, pero si un día o dos, qué barbaridad... por ejemplo aquí en este lugar que ponen la música tan fuerte, los fines de semana que viene la gente a divertirse, pero es lo mismo que pasa en los restaurantes o los cafés, si la gente va a platicar, porqué tienen que poner la música tan fuerte?

Yo no se si se volvió una moda, pero a fuerzas tienen que poner música... Sabes que yo si soy una gente muy sensible al ruido y yo si creo que debería de haber una legislación en las ciudades, sobre el ruido, porque creo que el ruido $t$ genera estados anímicos, te genera violencia te genera depresión, te genera alteración en muchos aspectos, y hay una contaminación grave de este tipo de ruidos, porque es también... como el tono de voz de la gente hay unos que no hablan,
gritan $_{i}$

.... yo creo que a veces el alzar la voz se hace para marcar tu territorio o para demostrar quien es el más fuerte, y veo que hay gente que con un tono mucho más suave marca quien es el que manda

Pero los ruidos a mi me impactan mucho, ..... quizás porque recuerdo mi infancia cuando mis papás discutían se gritaban mucho, entonces yo los rechazo, odio los ruidos

Y volviendo a lo que me gustaría .... A mi me gustaría que siguiera conservando el sabor así como de pueblo, pero que la gente tenga mejores condiciones de vida, en sus casas, que ojalá se hagan campañas de educación, de concientización, al interior de sus vidas, porque se traduce al exterior y se vuelve en una comunidad más agradable para vivir.

C: Sobre todo porque en estos momentos se tienen que escuchar las voces de todos. Ya es un lugar conformado por muchas visiones, y bueno si esto no se aprecia, no se mide, no se valora, es muy probable que haya conflictos... porque un patrimonio, con ciertas expectativas y encuentran después que hay cuestiones diferentes y que no son modificables, yo creo que a muchos les puede provocar, un gran enojo o una gran frustración.

Claro porque los niveles de intolerancia cada vez están más altos. Fíjate que a mi la bicicleta que pasa con el pan, hay me encanta... se me hace una cosa padrísima, porque a mi esa parte no me molesta, lo considero como una parte muy bonita de la comunidad C: Y bueno, por último quisiera preguntarte acerca de algunos conflictos, que tu hayas presenciado, o enterado....que se
den o estén a punto de suceder

No no me ha tocado ver nada...

$\mathrm{C}$ : Ni te has enterado por medio de amistades o conocidos...

No, yo lo único que he sabido es que la venta de agua, en algun momento ha llegado a generar conflictos a nivel mayor, es lo único que yo se pero no me ha tocado verlo y ni se que haya sucedido...

C: Las pipas de agua?

$\mathrm{Si}$, se supone que alguien quiso que se parara la venta de agua pensando en cuidar los mantos de agua de aquí, y entonces había una persona que ni se te decir quien sea que vendía pipas de agua y llegó esta persona a decirle que ya dejara de estar explotando, que el agua era para este lugar, no para los de fuera, que si no lo hacía iba a ver que se le clausurara el pozo, ... me parece que al otro día amaneció muerto

Porque cuando nosotros llegamos aquí y sacamos el permiso de construcción y todo, lo primero que pregunté es y el agua adonde voy a pagar? Lo primero que ustedes tienen que hacer es perforar su pozo, porque si no no van a tener agua, aquí no hay red de agua, nunca la va a haber, .... Entonces pues eso tiene sus ventajas pero yo creo que con el tiempo se nos va a convertir en desventaja y por ahora es el gran negocio la venta de pipas...

\title{
- ENTREVISTA A AVECINDADA EN SAN ANDRES CHOLULA
}

Fecha: Junio, 2003

Lugar: San Andrés, Cholula

\author{
C: ¿Desde cuándo vives en San Andrés? \\ Desde hace tres años \\ C: ¿Porqué elegiste este lugar? \\ Por ser un lugar "rural", porque existen más casas y menos comercios. Esto lo relacionamos con más \\ Tranquilidad,...más seguridad, como "de pueblo", si, vida "de pueblo" \\ C: ¿Lo han confirmado al vivir ahí? \\ Sí, claro, el hecho que esté menos poblado es lo más importante, yo creo.
}


C: ¿alguna otra razón?

La tranquilidad, creo que es lo mejor.

C: ¿qué te gusta más del lugar?

La tranquilidad, la cordialidad de los vecinos. La gente del lugar te hace parte de......y el espacio. Todo es muy
holgado: los espacios, los entornos, la vista....

Yo no percibía lo que me hacía falta todo esto y ahora lo descubro. Creo que está relacionado con

Una búsqueda de origen, porque de alguna manera todos somos migrantes y el barrio, te arraiga...

C: ¿Qué actividades realizas cotidianamente en San Andrés?

Caminar, caminar, como ejercicio, a la zona de la pirámide...a la zona nueva. Caminar a la tortillería,

A la tiendita. Porque en realidad, cuando hago mis compras del mercado o debo llevar algo a reparar,

Voy a San Pedro, allá hago todo eso.

Otra cosa que hago es recibir a la gente......al jardinero, a la tortillera, ..... porque es muy bonito. A los

Pocos días que llegamos a San Andrés la gente llegó a la casa, a tocarnos y ofrecernos las tortillas,

Los tlacoyos, y el jardinero a hacer el jardín. Ah también la vecina que siembra flores, me fue a
Ofrecer flores.

C: ¿A que otros lugares vas?

A la iglesia no porque no soy católica, solo llevo a mi mamá cuando viene a visitarme......

Ah también me gusta ir a comprar las flores directamente a los productores, eso me gusta.

Interacciones con los vecinos.

C: ¿Qué trato has recibido de los sanandreseños?

Cordial, sonriente, receptivo, respetuoso. Desde que llegué no me he sentido observada, ni nada parecido, esto
me parece que es respetar al vecino.

C: ¿Cooperas con las festividades religiosas?

Me invitaron a pertenecer a la hermandad de floricultores, cooperé con 350 pesos y me invitaron a que fuera a

la iglesia a misa, que mandan celebrar ellos. Pero no fui.... nadie más me ha pedido

Cooperación..

C: ¿Qué opinas de las costumbres del pueblo como cerrar calles, echar cuetes, repicar campanas y la música en las fiestas? Lo que más me molesta es el ruido de las bocinas. En una ocasión ya fuimos a pedirle a los de la fiesta que le mueven las sillas para que paron. Yo creo que si piensan en los "otros", ya que aunque cierran las calles, pachanga, es decir es solo por un rato

$\mathrm{C}:$ ¿Asistes a las ferias?

No, eso si no me gusta, aparte creo que cada vez las hacen más grandes..... como no tengo niños chiquitos, tal vez por eso.

C: ¿Te sientes parte de la comunidad?

Yo creo que me siento integrada en los encuentros cotidianos, como por ejemplo cuando salgo a tirar la basura, es un momento en que se saluda uno con los vecinos y se comentan cosas. Me siento ajena por no asistir a eventos religiosos, como no soy católica, en lo religioso me siento "ajena"

Es importante que conozco a personas que a la vez son conocidas en la comunidad, por ejemplo, uno de ellos, el chofer de mi esposo, a quien conocemos desde antes de venir a vivir aquí. Entonces la gente ve que viene a mi casa, porque se la encargamos cuando salimos fuera, entonces entra y sale de la casa, porque es de mucha confianza. Resultó ser conocido del jardinero que vino a ofrecernos sus servicios y así te van conociendo, son gente. Esto es impora la comunidad porque esa gente da fé de y tal vez así dejes de ser "invisible" para la gente. Esto es importante en la vida campesina. En la medida en que participes en sus ritos te vas haciendo más
"visible", pero tampoco busco participar en ellos.....

C: ¿Qué opinas de la presencia cada vez mayor de avecindados?

Pues que van a cambiar muchas cosas, cambia la misma organización, el paisaje cambia muchísimo, mientras más se urbanice la zona.......se va a encarecer el terreno. Esa gente que son mis vecinos, va a llegar un momento en que van a cambiar, va a cambiar la vida de la comunidad.... C: ¿Qué opinas de la nueva zona que se está construyendo por la pirámide, a quiénes crees que está dirigida?
\[ \text { A mi me parece que a familias de migrantes...... } \] 
C: Y la zona de Mac Donalds y todo eso en la recta....

Me parece que fue una claudicación, fue una extensión de Angelópolis lo que quisieron hacer.

\section{- ENTREVISTA A AVECINDADA DE ENCLAVE(Universidad de las Américas) Fecha: Febrero 2004 \\ Lugar: San Andrés Cholula, (UDLAP)}

Avecindada desde hace 20 años. Vive en la zona residencial de la UDLA, su esposo trabaja ahí y sus hijos también estudian ahí. Ambos llegaron de México D.F. en los ochenta, y desde entonces habitan en esa casa.

C:¿Desde cuando vives aquí?

Ya tengo aquí como 20 años.

C:¿Porqué llegan a vivir aquí?

Por el trabajo de mi esposo, él llega como maestro de tiempo completo a la UDLA.

$\mathrm{C}:$ ¿De dónde vienen?

Yo del D.F., bueno, él también, aunque su familia es de Puebla., pero no vivía aquí desde hacía muchos años, llegamos del D.F. con un intervalo de dos años cuando estuvimos en Estados Unidos, previo a a nuestra llegada.

C:¿En qué año fue?

Yo creo que fue en el 85

C:Y cuando tu llegas aquí a San Andrés encuentras ya este lugar, donde estás viviendo ahorita, o estuviste viviendo en otra casa?

En otra casa....ah si, bueno es que estuve casi un año en Puebla y después a fines de 85 o principios de 86 , ya vine a vivir aquí a otra casita dentro de la misma universidad y a los pocos meses nos cambiamos aquí....

$\mathrm{C}: \mathrm{O}$ sea que sería como en el $87 \ldots$

NO en 86 porque aquí nació mi hijo.

C:Esta es la casa donde nacieron tus niños?

El chico, la mayor no nació aquí.

C: Digamos que este ha sido siempre el espacio familiar..

$\mathrm{Si}$, sí.

C:Y cuando tu llegas a este lugar, tienes contacto con el pueblo de San Andrés, o adonde te dirigías para resolver tus necesidades de compras, atención médica y demás...

Pues, si iba más al mercado de Cholula, de San Pedro...para mis compras y lo que son servicios de la luz por ejemplo, que también está allá básicamente. Pero también nunca dejé de ir al supermercado a Puebla. A Cholula más para cosas específicas como la fruta, la verdura, cosas así, el pan.

C: Y a San Andrés?

A San Andrés casi no tenía a qué ir.

C:Para pago de....

NO, para nada. Recientemente fui a sacar mi credencial de elector, bueno ni tan recientemente, ahí en la presidencia municipal. Y mis hijos también ahí fueron a sacar sus credenciales...

C: Pero en esa época tenías otras actividades que hacer para atender a tu familia, no sé como las escuelas de tus hijos todo era en Puebla?...

Escuela, sí....Llegando llegando sí, ya unos años después mis hijos estuvieron en una escuela Montessori que está aquí en San Andrés, Cholloyan.

C: Entonces ahí si te obligaba a ir diario verdad?

Sí,

C:Y cuánto tiempo estudiaron ahi? 
Yo creo que como unos 3, 4 años, después de ese colegio los cambié a otro, que también esta aquí en San Andrés, y también Montessori, cuando ya decidía que ya no iban a seguir en Montessori, los cambié a un colegio tradicional en Puebla.

C:Y no ibas a comprar algunos cosas como las tortillas....

No porque aquí la gente viene mucho a vender cosas entonces pues vienen a vender las tortillas, los lunes, hasta la fecha...todas las compras así del super, en Puebla o al mercado, de repente ya he ido a una panadería que está a quí atrás en San Andrés, pero como de antojo, porque tampoco...compro pan del diario, entonces voy pasando y... me dijeron, hay aquí atrás hay una panadería que hace muy buen pan y pasando ..ya he ido como tres veces.

C: Y alguna vez aunque sea por curiosidad para recorrer el pueblo, ver algún terreno o...

Bueno he ido a la, fui también cuando iba a bautizar a mi hijo, intentamos hacer todo el trámite a la parroquia de San Andrés, entonces fue como que el trámite inicial fue en San Andrés, pues se supone que nos tocaba, fuimos a una plática a la parroquia y demás, pero no nos gustó, ni la plática, nos ponían como muchas trabas, el párroco, no se, como que algo pasó que decidimos mejor vámonos a San Pedro, ... entonces...fuimos a San Pedro, y ahí hablamos con el párroco de San Pedro y se facilitaron las cosas y entonces lo bautizamos allá.... Y luego bueno fuimos a otro bautizo y una primera comunión ahí a la parroquia, pero fue como que algo social..

C: De alguien más de aquí?

Sí, de alguien más de aquí..Luego ... ¿̨a qué otra cosa he ido?...últimamente en el último mes hemos querido comprar una casa, y me gustaría quedarme aquí, en San Andrés o Cholula y encontré un lugar que me gustó mucho, pegadito de la parroquia, ya usada y todo a mis hijos también les gustaba pero ya no se hizo la operación, no nos alcanzó el dinero y ya pero nos gusta...

Tuve una amiga, una compañera de la UDLA, una estudiante, que en un tiempo vivió en San Andrés, muy cerquita del zócalo también, la iba a visitar, o cuando voy a visitar a otra amiga, pero su casa no se si es San Andrés o San Pedro, ....también con motivo de la escuela de mis hijos, este..llegué a ir al centro escolar de San Andrés, a festivales de la escuela, ves que van y concursan y baila, entonces fui.

C: Entonces digamos que estas son las partes que conoces de San Andrés: el zócalo, algunos lugares como la iglesia, la escuela que dices, la casa de una amiga que estaba por ahí y últimamente la panadería..

Sí, la presidencia municipal y el centro escolar.

C: Y ahorita en la actualidad sería eso también.

Sí,

Bueno ahora el Municipio de San Andrés ya es muy grande..cuando hablamos del municipio...

Si ahora se supone que es hasta Angelópolis, ahora.

Entonces te vas a Angelópolis y estás en San Andrés, pero ahora lo que me interesa es esta parte de aquí de la recta, de este lado, por ejemplo ahí, ahora visitas esos cafés, vas a Mc. Donalds..

Sí, voy a la gasolinera, a Blockbuster, a Mc. Donald de repente, porque en general a Mc. Donalds no voy a ninguno,...de repente...también a la concesionaria de la $\mathrm{VW}$, aluna vez llevamos el carro ahí...

C: ¿Y al centrito comercial que está ahí?

Sí también voy ahí de repente..a 100\% natural, tengo unos conocidos que tienen un restaurantcito ahí de tacos.. y a los otros cafecitos si he ido..no voy así muy seguido pero si voy.

C: Bueno y en cuanto a las interacciones con los vecinos, por ejemplo, que trato tienes con gente de San Andrés? Bueno la muchacha que trabaja conmigo es de San Andrés y ya tiene varios años, como 3,4 y va y viene diario, no se donde queda su casa pero se qué es en San Andrés y viene en bicicleta.... algunos jardineros que conozco desde hace mucho son de San Andrés.....

C: ¿La señora de las tortillas?

No esa es viene de otro pueblo por San martín Tex. En el camino a San Martín

C: ¿Y algún otro vendedor?

Viene otro que es muy asiduo que arregla zapatos, pero no sé de donde venga... debe vivir por aquí cerca pero no se..

C: Y de esa gente que tu tratas o por terceras personas te haz formado alguna opinión de la gente de San Andrés? $\mathrm{Y}$ a través de tu muchacha.... 
No, ella es muy formal, en su trabajo, puntual, luego me cuenta de sus peripecias con sus hijos, en la escuela, que les piden dinero, cooperaciones, cosas que....cuando he ido a la presidencia municipal, la gente es amable, el párroco que recuerdo en aquel entonces, así como cascarrabias, así como el clásico o típico de pueblo regañón no..

C: Oye y a través de tus hijos luego comentan, acerca de algunos amigos que les hayan pasado algo...escuches los chavos que opinan...

Pues no, nunca he sabido de ningún,..... pero si también tengo la idea de que junto a la gente que es como más humilde, la que siempre ha vivido aquí, ha llegado gente nueva no.. de otros lados, supongo y que hay un poco, como que han proliferado los negocios para jóvenes: discotecas, bares, restaurante de comida rápida, de bares y de diversión nocturna y las fiestas, digo aquí se oye la fiesta casi cada fin de semana que puede ser como fiesta del patrono, que se identifica por los cuetes, las campanas de las iglesias y ese tipo de cosas o fiestas familiares como bodas, cumpleaños, que hay seguido.

C: Y qué opinas de eso, de los cuetes, las campanas, el cierre de calles...

Pues mira las fiestas religiosas así tradicionales de las iglesias, no me molestan o sea se me hace una cosa como que forma parte de la cultura del pueblo y bueno fuera de las campanas y los cuetes no oigo más o que ponen flores y ensucian un poco la calle...nadamás, pero lo que es las fiestas ya de otro tipo, como mas urbanas, a veces si son molestas porque siento que no respetan al vecindario, o sea, la gente hace su fiesta, no se que haya, pero por ej. Aquí atrás en la calle de atrás no se que haya, debe haber un terreno o salón o algo, que ya últimamente no he escuchado pero hubo una temporada que cada ratito había fiesta de esas de conjunto o luz y sonido o ve tu a saber y se notaba que era una fiesta pues si familiar pero donde se amanecen con la música a todo vol. Y no dejan dormir...como de veras muy fuerte, y eso es muy molesto y que eso es así como comúin esa onda de las fiestas y de que a mi no me importa el vecino, cierro la calle o la hago en mi patio y yo no se

C: ¿Ý de los antros?

Se que hay o he oído, a mi no me consta, como que hay problemas de droga, de prostitución, alcoholismo, y como que eso no es sano y sobretodo es como algo que atrae a la juventud... hay muchos que van ahí y se meten, o los jalan o les gusta...pero que creo que si hay bastante de eso..Con mis hijos así directamente pues no, de repente van a algún lugar y me cuentan, pero no le entren o se dan cuenta que existen esas cosas pero no forman parte. Entonces por esa lado no me preocupa mucho porque no les veo que les jale eso, pero pues hay otros muchachos que si, porque si creo que es verdad que existen esas cosas...

C: Y por ejemplo ¿ellos no te han comentado si jóvenes de la comunidad participan en eso?

No se fijate si sea de gente de fueras o ..me da la impresión que no son la gente originaria de San Andres la que participa de esas cosas, o uno que otro tal vez, bueno he escuchado... alguna vez escuché que el hermano del jardinero, como tienen terrenos, los venden o los fraccionan y ahí ponen su bar o negocio sin mucha idea, o sin mucha conciencia de que se den esas cosas... pero yo no se que tanto sea un dato aislado o no creo que esa tanto así que sea un interés o un negocio de la gente de aquí, sino que a lo mejor uno que otro se pone listo o se deja convencer por alguien.

$\mathrm{C}: \mathrm{Y}$ ¿no has recibido ninguna invitación para cooperar en las fiestas?

No,

C: ¿No viene aquí a pedir?

No.

C: Y asistir a las fiestas religiosas, por ejemplo las fiestas más grandes del Santo Patrono en noviembre o la bajada de la virgen en julio, esas son las fiestas más grandes en donde yo creo que oyes más ruido..

Si esas son las que se oyen a veces se oyen las campanas de la iglesia y de repente hasta el sermón del padre se oye, se ve que usa un micrófono...

C: Bueno es que la iglesia está pegadita aquí ¿¿ si sabes de qué barrio es?

No

C: Es San Juan y la fiesta es también en junio... pero nunca has ido a ver?

NO nunca, a lo mejor me ha tocado de casualidad que voy en la calle y veo que va la procesión con la Virgen y tirando

florecitas... pero nunca he participado ni he ido a

C: Cuando te has metido un poco más al pueblo, haz visto que tienen terrenos baldíos y asoleaderos de estiércol y de repente pues eso llega a producir un olor....

NO he visto terrenos pero no me he dado cuenta de eso... ah otro lugar que también he frecuentado es el Hotel...el

Mediterraneé, me acordé porque alrededor hay mucho lotes ..

C: En general ¿ves que el pueblo lo mantienen limpio o...?

No tanto, ha mejorado mucho, todo el zócalo, lo veo mas cuidadito pero en general no.. 
$\mathrm{C}$ : Y te has fijado.... en que tienen crías de marranos, de ganado lechero, que hay algunas lecherías que te venden queso, crema, leche y bueno obviamente están las vacas ahí y el olor y todo eso, ¿tu crees que estén bien ahí esas actividades todavía, que en determinado momento tú decides ir a vivir adentro del pueblo ahí encuentras una casa que te guste, escoges un terreno agradable y entonces ya tienes a un vecino que tiene todo eso ¿que opinarías?.... Sería un impedimento para que tu te instalaras?

Hijoles.... Pues no, no había......... por un lado lo entiendo y hasta se me hace atractivo, como que todavía Esa parte de las tradiciones, aunque yo no compraría leche de esa, o sea nunca he comprado leche bronca, pero en principio como que... no me impediría, ya viéndolo bien, yo no sé, si de repente viviendo ya ahí viera yo que de repente ya es el mosquerío, o que empieza a haber un olor desagradable todo el tiempo, ....ya no me gustaría.

$\infty$

\section{- ENTREVISTA-PLÁTICA CON ORIGINARIA}

Fecha: Marzo, 2009.

Lugar: San Andrés Cholula

Mujer de 37 años, madre de 5 hijos con edades que fluctúan entre los 19 y 7 años. Es originaria de San Andrés y vive en el barrio de Santiago.

Ocupación: Madre de familia, vende productos Avon. Anteriormente fabricaban y vendían productos lácteos ahí mismo en su casa, porque su marido tenía vacas y esa era su actividad principal. Es la razón por la que en el exterior aparece en la azotea un becerro hecho de pasta o madera y las puertas que dan al exterior son de madera, dando una apariencia de casa tipo nórdiko, como si hubiera sido copiada de una revista.

C: Quisiera que platicáramos acerca de los cambios que últimamente, o de unos 4 años para acá, ha tenido San Andrés y cómo se siente con ellos.

Pues a mí lo que me tiene preocupada o lo que me molesta es el apoyo a estudiantes que según los de acá les dan a los estudiantes. Sí porque los invitan a participar en las fiestas, de castilleros, floreras, que pa una fiesta que para otra, porque acá no son tres fiestas al año o cuatro, son muchas. Además las fiestas se han alargado.... Ahora por ejemplo, hay una "bajada" de la V. de los Remedios el 18 de marzo que antes no había. Y ya tenemos una en julio y otra en noviembre que en realidad son dos: una del pueblo y otra acá del barrio. Entonces yo digo que es un tiradero de dinero y pues las cooperaciones que piden también a los muchachos, estudiantes, pues no les gusta y mejor se van de acá...

Otra cosa es que antes había más provecho de los terrenos..... ahora todo es químico lo que comemos, y es que muchos venden y se van pal otro lado (EU) y quien compra lo vuelve a vender y ahí se van ... eso nos tiene algo inquietos y ilos accidentes;

C: ¿cuáles accidentes?

Pues no hace mucho acuchillaron a uno por acá y luego dicen que somos nosotros, los de acá, y no porque son los de Veracrúz, unos de un pueblo que se llama Altotonga. Entonces se han venido muchos de por allá y de la sierra norte y están por todos lados. Luego se da uno cuenta por su forma de vestir, sus sombreros...

C: ¿qué hacen?

Pues andan en la construcción. Los hombres son albañiles y las mujeres pues se ofrecen para hacer el aseo en las casas. A mi suegra le han pedido trabajo y ella les dice, no, ya tengo a mis nueras que me ayudañ.

Mi esposo es albañil y ya tuvo a dos de ellos y le platicaron que acá pagan mucho más que de donde son ellos. Pues pobres también, como va a estar bien que les paguen por un día de estar cortando café 50 pesos, en cambio acá ganan mucho más.

Empezaron a llegar desde el 97 o 98

C: ¿están viviendo en un lugar en especial?

No andan por todas partes,

Pero por ejemplo a mi hijo ya le robaron una bicicleta, otro sobrino los vió y le dijo que uno de ellos se la había llevado y así andan, luego se conocen porque se visten de otro modo, entonces ya no sabe uno de quien cuidarse y yo digo:

¿vendrán más?

C: Y las calles?

Pues acá hace como dos años que las pavimentaron y pues si le digo a mi esposo que ahora está más peligroso porque los carros ven más "lisito" y quieren correr y ganar uno a otro y acá en la esquina ya ha habido sus choquecitos y los niños? Si está más peligroso pero se ve mejor, está bien...

Y de los departamentos, ahora cuan más ya hizo su departamento y ya rentan. Le digo a mi esposo dondequiera que voy está: se renta departamento, se renta departamento...

C: ¿cómo ve lo de la renta de departamentos?

Pues está bien, aunque también hay unos estudiantes perjuiciosos y sobre todo que ahí andan, tomando, fumando esa cochinada ... si nosotros no consumimos eso.. Y luego a este niño le llama la atención estarlos espiando y ya viene y me cuenta. 
Porque yo no se que tanto hacen, pero luego las muchachas se visten con sus trajes de hawaianas, o luego se ponen unos como de enfermeras con sus faldas cortitas y quiensabe cuanto hacen. Ya en la madrugada ahí se andan jaloneando la muchacha y el muchacho pegando de gritos... y yo que pensaba que los que tienen más dinero eran los mejor comportados, pero mientras no se metan con nosotros, pues allá ellos... y es que son estudiantes.

Otro problema de por acá es que ya hay bandas de graffittis y si usted se fija todo está grafiteado, acá la puerta ya nos la grafitearon. Yo le digo a mijo, eso está mal, y si tu te llevas con ellos pues van a decir que tu eres uno de ellos, eso está mal..

Yo les digo a mis hijos "antes no había luz pero era más seguro....ora hay más luz y está más inseguro???". Ora hay que estar más al pendiente, no todos son malos, debe haber uno o dos que venden la "mota" pero uno tiene que estar con los ojos bien abiertos.

Luego en la escuela, pus reciben a todos los que quieren entrar, recibe a gente fuera, y hay niños con otra forma de ver las cosas...va una señora que lleva un niño chiquito..más chiquito que el mío y ya habla como adulto, ahí esta jugando y hablando el solo pero como adulto y diciendo cada cosa.... Yo creo que es de esta gente de Veracrúz, y este niño todavía llega y me pregunta: mamá verda que esto o lo otro, o porque esto es así? Pero ese niño no

C: Y la relación con los inquilinos...

Pues hay gente encajosa, como le digo a mi suegra que esta rentando aquí varios cuartos: pus si usté les está dando la luz, el gas, el agua, y todavía se atrasan en la renta de hasta de un mes, porque nomás llegan y le dicen a usté: no sea malita me espera una semana, y luego otra más y así se siguen hasta un mes..... gente encajosa.

Llegan con mi suegra y ella les dice vale tanto...y ellos andan: no sea malita déjemelo en tanto...mi esposo le dice : hay mamá pero cómo se los diste en tanto si les estás dando agua, luz, gas....

C: ¿Qué beneficios encuentra en todo esto que está sucediendo, para sus hijos...?

Para mis hijos....Nadaj... Bueno va progresando porque más antes todo estaba lleno de terrenos, de plantas... ahora ya hay luz pero... sí me gusta todo de acá para mis hijos.

$\mathrm{C}: \mathrm{Y}$ ¿a futuro?

Me gustaría menos antros porque los pervierten... más trabajo para mis hijos porque ya ve como están las cosas.

C: ¿Qué estudian sus hijos?

Mi hijo mayor estudió cómputo y plomería que le enseñó un tío, también sabe de albañilería que le enseñó su papá. Yo le digo, que es bueno que sepa de todo pa que si no hay trabajo de una cosa hay de otra.

También me gustaría que regresara lo de la ganadería, porque cuando los dos mayores estaban chiquitos, crecieron entre animales y a estos ya no les tocó. Yo estaba haciendo los quesos y me pedían que les diera, les hacía sus tacos con sal... C: Y ahora me imagino que debe haber más actividades para ustedes, las señoras, que no estén tan encerradas como antes...

Si hay clases de bordado, pintura, cocina, de cosas para la navidad

C: y de computación?

No solo para niños.

$\mathrm{C}$ : Y que costo tienen?

De a 20 pesos a la semana..

Pues yo les digo a mis hijos que a mí me gustaría que regresaran los tiempos de los calzones de manta y ellos me dicen: hay tu te quedaste traumada con eso....ven fotos viejitas, de la gente descalza y les digo así andaban todos, a ustedes ya les toco desde que nacieron zapatos...

Ahora mi hija me dice: ya quitate ese mandil, ¿pa que te lo pones?....pues para cocinar... ¿y que no puedes cocinar sin el mandil?...no le gusta

A mis hijos les gusta el ahora, lo de ahora...

C: Oiga y los tiraderos de estiércol, porque los han quitado? Que el presidente municipal ha puesto algunas restricciones para eso?

El anterior, dijo que iba a multar a los tiraderos de estiércol porque eso era pura contaminación, pero vimos que no pasó nada, todo siguió igual....

Ahora ya pasa más días el camión de la basura y ya no hay tiraderos de estiércol....pero nos dicen que nos van a cobrar lo del camión, nos van a pasar un recibo....

En la escuela ponen a reciclar a los niños, cartón, plástico.... Y ya les hablan los maestros de la contaminación ... que los vasos desechables dilatan no se cuanto para reciclarse y aquí con tanta fiesta que ahora sirven todo en vaso desechable, todo es desechable.... Antes les digo a mis hijos tan bonito que te servían el refresco en vasos de vidrio...

C: Y los antros, también usan desechables que dejan tirados afuera en las calles no?

$\mathrm{Si}$, ya hubo una protesta hace 4 años, todos los de San Juan, por el basurero, el escándalo, por andar haciendo "disfiguros" en la calle, en los coches, diciendo que era un mal ejemplo para sus hijos, fueron a ver al presidente y les dijo que si tenían razón y que ya se iban a cerrar....entonces los cerraron como dos meses nadamás y luego.... Apareció otro, y otro, y otro más..

Entonces eso es lo que también nos da coraje con este presidente, porque .... Vienen y construyen y ya, parece que tienen más preferencia que nosotros?, porque el presidente no nos da a saber a nosotros de los antros, solo de que ya gastó en esto y lo otro, pero de los antros no nos dice nada... Los de San Juan deben saber y van a la presidencia a pararse, pero ellos tienen la culpa porque desde el primero que dejaron debían haberle dicho que se podía hacer y si no que se fuera pa otro lado... 


\section{- ENTREVISTA A Originario}

Fecha: Abril, 2009

Lugar. San Andrés Cholula

Edad: 71 años

Oriundo de San Andrés, habitante del barrio de Sto. Niño, padre de 6 hijos, agricultor, ganadero, estudiante de Veterinaria a edad adulta. Se ha destacado por participar políticamente en la comisión pro-defensa de los límites territoriales de San Andrés, Cholula. En 1974, lo nombran secretario de esta comisión y acuden al archivo general de la nación para solicitar el plano original de los límites del municipio, para lo cual recibe apoyo de un reconocido antropólogo, estudioso de la zona de Cholula, Cayetano Reyes, quien les había informado anticipadamente de la existencia del mismo, obteniéndolo y conservándolo en su poder hasta la fecha. También es reconocido por sus conocimientos sobre historia del lugar e interés por destacar y preservar las "buenas" costumbres del pueblo.

Sobre la transformación actual y cambios en el municipio:

C: Ahora es enfrentar al enemigo de otra manera...

El enemigo que tenemos es el sistema, es un enemigo disfrazado ...

Yo agradezco a mis compañeros que se hayan mantenido unidos... para defender a nuestro municipio porque hubo ya un intento de desaparecernos como municipio libre, Puebla y San Pedro estaban poniéndose de acuerdo para eso.

C: Y la situación actual, que atrae a tantas gentes para venir a vivir acá? O sea, cuál es el motivo, a qué vienen, qué encuentran acá?

Les hace llegar más que nada la curiosidad, de... cómo se vive con gran tranquilidad, armonía, todos nos conocemos en este lugar...

La nueva gente están encontrando lugares y ya le están dando vida a la pirámide, van encontrando el tesoro que estaba enterrado.... Entonces nosotros empezamos a proyectar todo esto

C: Eso es en el área de la pirámide, pero en el área del periférico que se han construido condominios con departamentos de lujo, rentas carísimas....y muchos vacíos..

$\mathrm{Si}$, si es cierto, pues todo esto el propio gobierno del estado le ha dado la tolerancia, y cooperación, y como tenemos un agua muy buena, aquí no tenemos drenaje, bueno, tenemos drenaje pero no tenemos agua potable, todos nos hemos opuesto porque el estado se beneficia con eso, a lo mejor más adelante si se hace pero aquí todas las casas tenemos pozos y $\ldots$.

C: Y están entonces encontrando beneficios con estos cambios?

Si porque por lo menos construimos departamentos y ya podemos rentarlos, a menos costo, a menos costo....por allá un departamento de a 1,500 nadie se lo renta, los que cobramos menos somos los que rentamos acá

C: Y usted ¿ya ha construido algo para rentar?

Si ya tengo atrás de la casa dos departamentos

Tengo uno con dos cuartos y su baño, 1400. Pero ahorita lo voy a remodelar..tengo todo rentado, pero pal 3 de mayo... ya queda libre..

No aquí está barata la renta...tan más caras las rentas allá...pero ya por aquí ya no.

C: Cómo que si están concentrados los avecindados allá, bueno ya están por todos lados.

Si pero, si están más allá. Aquí mi vecino construyó 15 cuartos y pide 500 de renta, pero con baño compartido. Pero fijese usted 500 pesos está bien.. aquí a la vuelta están los baños públicos

$\mathrm{C}$ : Y ¿sigue usted con sus actividades de ganadería?

$\mathrm{Si}$,

C: Se ha mantenido más o menos esta actividad ¿verdad?

Si, éramos muchos pero ahora ya nomás somos como 70 ,

C: Venden la leche, hacen quesos..

Si todavía, todavía, si pues esa fue su mayor fuente de ingresos de la comunidad. Ahora ya las vacas se convirtieron en taxis, muchos se fueron de obreros, entonces... ya es otro nivel de vida.

C: por ejemplo sus hijos ¿a qué se dedican?

Todos ellos tienen ya sus talleres de vulcanizadoras, otro tiene su taller de bicicletas...

C: ¿No tiene ningún hijo en Estados Unidos?

Si tengo uno en los Ángeles.... pues ya ve están jóvenes y tienen sus ilusiones, no los puede uno de tener. Otro también se quiso ir pero se enfermó y se regresó, allá no le pudieron detectar, en cambio aquí luego luego.

C: Pues que bueno que los tenga aquí a todos, ya hay más escuelas para sus nietos también

Sí, oiga usted yo me preocupaba por eso porque no había escuelas, pero ahora ya tenemos escuelas, preparatorias,

universidades y eso es para bien

C: Entonces ¿usted ve eso como beneficio también para la comunidad?

$\mathrm{Si}$ a futuro, porque yo ya comprendí que el beneficio de un pueblo es la preparación..... Yo lo viví cuando me metí en eso de la veterinaria, pasé de agricultor a veterinario y fue un cambio de vida..

Desgraciadamente nuestras autoridades no están bien preparadas, si fuera así ya se hubiera avanzado más. No van a avanzar porque..........

C: ¿Qué otras medidas inmediatas tienen ustedes así como para conservar el orden urbano y...

Que cada Municipalidad, junta auxiliar, vaya haciendo sus planos donde marque sus límites territoriales, bien definidos, claros, ... para que no tenga problemas con su territorio. 
Yo les he propuesto a los presidentes en turno, mi proyecto con una visión a futuro, de un "mercado mundial", no imagínese con la cuestión cultural.... Para empezar empezamos con unas dos has. Luego llegamos a 100 has, en 100 has, se va acomodando una central camionera, para trailers, descargas, para las camionetas, para los coches, ... un centro de abasto construido a lo moderno, lo más moderno. Cada local será de dos pisos, abajo la venta, arriba la bodega, con su cuarto de baño cada local.. sería un éxitoi

C: O sea, ¿cree usted tener esa apertura de mente, aparte de ser visionario, esa apertura de mente para no aislarse, sino abierto a tener más contacto con todo el mundo, que me conozcan y yo conocerlos...?

Eso, eso...

C: ¿usted cree que eso proviene de sus antepasados, o de dónde, cómo se lo explicaría eso, esa mentalidad?

Mire, cuando nosotros comenzamos a hacer nuestra investigación fuimos encontrando esa necesidad y surgió esa idea de que había que ampliarnos, de eso fuimos hablando... Yo les dije: miren, se nos viene la ciudad encima y no lo podemos detener.....

¿cuándo se elevó y se hizo famoso este lugar de Cholula? Porque eran unos grandes alfareros, unos grandes comerciantes, unos grandes estudiosos, ... las caravanas que venían desde Groenlandia, del norte, como de Chile, del sur,..... llegaban aquí a la pirámide, pero no había como ahorita todo esto moderno....venían a ver que había.... La curiosidad de saber que...

C: La curiosidad entonces les hizo llegar hasta acá..

Si porque había una gran cultura, muy estudiosa, una gran civilización... entonces nosotros estábamos platicando de que, son los espíritus que deciden vivir en este lugar... no los vemos pero ahí están, ....los seres humanos nacen para Dios y Dios quiere que los seres humanos vivan en armonía, creo que es lo que estamos haciendo.... Esta cultura así es....pero los conquistadores en lugar de que nos beneficiaran nos perjudicaron....Porque los que nos vinieron a conquistar fueron los malos, los ex presidiarios... La escoria... por eso nos dejaron todos los defectos: la discordia, todo lo que deteriora a la sociedad

Cuando llegó Cortés, se quedó admirado de la gran pirámide, cómo tenía sus jardines colgantes.... Sí, ahí Bernal Díaz del Castillo narra en su libro... ¿no la usted leído?... Entonces nosotros teníamos la idea de llegar hasta Sevilla a conseguir los planos originales, entonces, ¿qué necesitamos? Nomás necesitamos seguir presionando, hacer una solicitud al gobierno federal... yo ya hasta preví cómo vamos a hacer las cosas...

C: Ya lo tiene usted previsto...

$\mathrm{Si}$, porque yo ya les dije, miren señores, ya la salvamos porque ya ve que generamos algo de controversia, ya usted lo ve... ve usted toda la 14, el Camino Real le dicen, ya está todo lleno ya de negocios... ya es una ciudad....no si entre jueves, viernes y sábado...es una feria.

C: Sí si

Usted venga una día en la noche, si quiere usted distraerse. San Pedro no lo puede creer, y no va a poder, ellos no lo van a lograr.... El gobernador que fue de San Pedro, el Dr. Toxqui, construyeron la recta para beneficiar a San Pedro y salimos beneficiados nosotros....(ja,ja,ja)

C: Pues si y la Universidad de las Américas ¿no?

Eso ya fue otro proyecto antes... el dueño de ese rancho, porque era rancho, este... fueron siete dueños, eran 5 hijos, hermanos, al no poder ponerse de acuerdo para vender un hermano les dijo yo les compro pero luego no podía pagarles, entonces se obligaron a venderlo y entró un cuñado que tenía el dinero y se quedó con el rancho, era Justo Fernández, y ese señor le vendió a la universidad el terreno. Justo Fernández de los Avilacamachistas..

$\mathrm{C}$ : Y ahora no se preocupan porque llegue gente más voraz, empresarios, que únicamente busquen beneficios económicos, sin importarles más allá, que la gente de aquí esté a gusto, con todo lo que hacen...

No mire usted, por eso le digo lo del proyecto, con eso vamos a ganar..

C: Pero mientras, cómo manejan eso, cómo lo controlan, cómo se resguardan?

Mire, mire, nosotros nos resguardamos, de los empresarios más dificiles, con el precio de los terrenos, ahí los espantamos...

$\mathrm{C}: \mathrm{Y}$ todos esos negocios que están en la 14 ¿tienen terrenos rentados o ya los han vendido?

No, son rentados... los propietarios son de acá

C: Ahí es donde ustedes mantienen ...

Ándele usted, otra fuente de ingresos, si no nos parece les decimos desocúpeme usted... Mire lo que Salinas hizo allá por el 91 , con el régimen de ejidatarios y luego aquí con la pirámide que la vendió a una empresa japonesa

C: O sea, lo que se dijo también del volcán, el popocatépetl

Sí, ese también, si yo lo ví en los decretos, apoco cree usted que nomás vi los del municipio..?

C: ¿Y el INAH?

Mire atrás del INAH está el dinero de grandes empresas transnacionales, a través de proyectos de Alemania, EUA,

Inglaterra, Francia, España.... Entonces cuando encuentran un tesoro, ¿de a cómo nos llevamos? Cierto o no?

Si aquí se encontró una serpiente con una cabeza de oro, que ni la pluma la podía levantar..

$\mathrm{C}:$ ¿en dónde?

Aquí en la zona arqueológica, no lo levantó la pluma.. y muchas cosas, quien es el culpable, es nuestro sistema el propio gobierno.

C: ¿y qué hicieron con eso? 
Quiensabe... porqué estamos cayendo cada día más? es que nuestro gobierno no es gobierno del pueblo, es gobierno todavía de españoles, siguen adueñándose de todo, cierto o no?

$\mathrm{C}: \mathrm{Si}$, ahora hay una nueva conquista, con el petróleo, las refinerías....

Usted que se da cuenta, ¿usted cree que el presidente de la república deveras ganó limpiamente?

C: ¿para mí?

No nomás pa usted, al pueblo ya no lo van a engañar...porqué está la televisión, porqué está la prensa, porqué está la computadora, ... yo nomás tengo nociones

Pues ya le digo a usted, se los dije a todos ellos, nosotros vamos a ser los pedestales de este municipio, en menos de 10 años... Nomás donde ellos agarren mi proyecto, agárrese usted.. no...

C: Ojalá

No crea, nos hablan las empresas cuando tienen proyectos, llegan los coyotes esos... vinieron una vez, vinieron también los muchachos y me dijeron: quieren que les vendamos,... cuánto quieren? 50 has. , y que dijeron ustedes? ... Que lo que usted diga, ... mmh, y les gusta? ... sí,.... Pues a $\$ 1,500.00 /$ ha, entonces los coyotes dijeron, no aquí esta muy caro... nosotros no queremos dinero, queremos nuestra tierra, entonces no..... ha y uno que otro que si vende. Yo allá en la recta, tengo un cuarto de hectárea, y lo doy de 5,000, y si no quieren, no tengo necesidad, que es muy caro dicen... me ofrecían de a 3,500 ... si tienen 5 órale, entramos al negocio, me retiro con muy buen dinero,

Ya nomás somos tres personas que tenemos ahí propiedad, ... pero yo tengo mis hijos, ahí que finquen que hagan una privada... pero los coyotes les digo si quieren denme 5 y le entro

C: No, es que de un terreno así sacan un montón de casas, aquí vi en la 6 que han construido en un lote así muchas casitas pequeñas, de lado a lado, y ya son bloques de 10 casas, 15 casas, ahora ya son 25 donde antes eran 4 propiedades... Andele, así es, ahora porque ya hay control de natalidad y es que antes era otra época, teníamos de a 8 de 6 hijos, ahora no...

............. Don Delfino platica acerca de que ha sido invitado a ocupar puestos políticos pero él se ha negado, está convencido que el poder y el dinero corrompen a las personas, porque el hombre es ambicioso por naturaleza. El prefiere el puesto que ocupa en el Comité porque es vitalicio y también le dá poder....

C: Y ¿cómo ve el futuro o cómo se le antoja, para el municipio, para sus hijos...?

Mire vi en las noticias y ya otorgaron un poder, poder notarial, a este municipio como ciudad distrital, ... está arriba del municipio de San Pedro y del de Puebla....

C: Y entonces $¿$ cuando yo escucho que el presidente actual dice que va a retomar el asunto de la defensa de los límites territoriales $i ? ?$ ?

Mire, lo que pasa es que quieren darle publicidad, hacerse publicidad

C: O sea que es otro discursos...

Ándele, usted lo acaba de decir, otro discurso para prensa y para el mundo entero...

$\mathrm{C}$ : pero entonces ya está resuelto...

Si ya está resuelto, nosotros tenemos el documento dirigido a Marín, donde Derechos Humanos y Gobernación le dicen, también a Doger: toda intervención, en el municipio de San Andrés, será invalidado..ahorita está en pleito lo del predial que los obligan a pagar acá.

C: Si, pues tiene que ser, lo de San Andrés, es para San Andrés...

Pero las autoridades de acá son incapaces, yo ya les he dicho: si ustedes tienen el poder, usen el poder;

$\mathrm{C}$ : Y es que ante el gobernador...se someten, porque jerárquicamente el gobernador es más que las autoridades municipales.

El gobernador es el que manda en todo el estado, administra, pero no es el dueño de los pueblosi

C: Ahí está la diferencia...

Eh.. entonces los dueños de los pueblos son los ayuntamientos, ellos son los que ahí viven y saben cómo mantienen a su gente.

C. Oiga y los proyectos turísticos, cómo los ve usted aquí?

No, van bien, ya le van dando cauce, y hay algunos que lo van a levantar, se va a levantar..

C: ¿Cómo cuáles?

Pues ahorita como el de de la pirámide, sí porque ahora ya el municipio se está haciendo cargo directamente...

C"O sea, que ahora ya se entienden directamente con San Andrés para cualquier proyecto que tenga que ver con la pirámide?

Si, si, mire uste.... Yo fui testigo un 20 de agosto de 197.. adonde se declara en el Diario Oficial de la Nación que la pirámide se le encarga a San Andrés.

Entonces San Pedro es ciudad nomás y ya no tiene pa donde crecer, ya está todo lleno..

C: ¿Qué extensión tiene San Andrés?

$68 \mathrm{Km} .2$

C: Y San Pedro?

$51 \mathrm{Km} .2$, entonces este municipio va a ser el mejor, la misma gente lo va a levantar, usted lo está viendo en la $14 \ldots$ venga usted un viernes o un sábado y verá... se va usted a llevar la sorpresa ¿pues qué es feria o qué?...todos los negocios, todas las dischoteques, y es vida..

C: Yo solo he escuchado que la gente se queja ahora de que ya hay mucho carro, que ya no pueden mandar a sus hijos solos a la escuela... 
Sí porque en la ciudad de San Pedro ya no, todo transita por acá, la gente se queja de los semáforos, pero solo hay 2, en la $14 \ldots \ldots \ldots \ldots \ldots \ldots$ pero hay orden y hay disciplina y eso lo traemos de nuestros ancestros, y los espíritus que nos resguardan.... Yo para mí digo que eso es, no es otra cosa,

C: pues que bueno, que la urbanización sea para bien...

Si la vemos de esa manera, y es que ya nosotros ya nos dimos cuenta, no podemos parar el crecimiento ...

$\infty$

\section{- ENTREVISTA A ORIGINARIO “MODERNIZADOR"}

Fecha: Mayo, 2009.

Lugar: San Andrés Cholula

65 años(aprox.), Abogado, empresario, vecino de Barrio Santa María

C: Y justamente con estos cambios que ha tenido San Andrés es que quisiera preguntarle... san Andrés era conocido por su producción de hortalizas, lechera.. y todo eso se ha modificado...

F: Se ha modificado totalmente, tanto la alimentación del ganado, del campo, ya está todo cambiado, las hortalizas que también ya desapareció, sembraban flores, pero flor de la región no digamos que como la de ahora, digamos que gladiolas... no flor de la región, incluso van desapareciendo, eh, eran como por ejemplo las nubes, es muy tradicional por este rumbo, las alelías, las espuelas, las esponjas, las esponjas, las mercadelas, las margaritas, el margaritón, todo eso que era una flor que se daba en cantidad, todo esa ya no la encuentras por acá, más que la flor de muerto que se cosecha en... todos santos, pues esa, el que tiene terreno la cosecha muy ligeramente, pero ya casi tampoco

$\mathrm{C}: \mathrm{Y}$ ¿qué factores son los que usted cree o considera que han afectado?

F: En primera eh... el cambio del tiempo, el retraso de las lluvias, la aparición de plagas, en fin y lógico que eso viene aumentando por ejemplo, anteriormente en los caminos eran de terracería, pero si bien era cierto que eran de terracería, no había polvo, y hoy pasan los carros y en ambos lados de los terrenos esos ya no se da nada porque el polvo se lo acaba. El polvo, las lluvias tan retrasadas que ya han venido, pues anteriormente se sembraba en marzo, ahorita es junio y todavía es ahora que no siembran, entonces todo eso....

C: ¿Qué otras cosas cree que han venido afectando?

F: Pues todo eso ha venido afectando, desde a la gente, a las personas, a sus habitantes, hasta sus animales, eh?, ya no ya no hay tanto pues el ganado de corral que había o sea, a hoy todavía hay quienes se dedican todavía a las vacas pero ya no producen ellos mismos su forraje....cuando estas tierras fueron totalmente muy productivas y abastecían tanto la alimentación para las personas como para su ganado, sus animales, porque...

C: ¿A partir más o menos de que año, empiezan estos cambios?

F: Esos cambios... claro, ya me comentaban que esos cambios ya había venido pues anteriormente, había ciclos buenos y ciclos malos, como todos, pero estos cambios a través del año....sesenta y... los acentuaron más en el 66 al menos en esta región. En ese entonces yo le argumento que es al cambio que tuvo la región, el cambio porque se vinieron la primera gran factoría que se vino a asentar, o la gran el cambio total que vino a hacer fue la Universidad de las Américas, a la par en ese entonces, el descubrimiento de la pirámide..

C: En ese entonces ifue cuando se echo a andar el Proyecto Marquina?

F: El Proyecto exactamente el Proyecto de Marquina, entonces toda la gente que laboraba en el campo, aquí en ese entonces toda la gente que laboraba en el campo ganaba 60 pesos a la semana y en el Proyecto de la Pirámide, para descubrir el tramo que está descubierto, porque antes no se veía nada de pirámide, todo era por túneles, el proyecto ese que le dieron a la universidad la parte esa que descubrieron se llevó algunos años, y a la gente si el campesino ganaba en ese entonces 60 pesos, y en ese proyecto al trabajador de fuera del campo, el que estaba rascando el registro de estudio, y todo eso, no sé cómo le.... el término real que le ponen ustedes, pa rascar, a ese le pagaban 105 a la semana y pues no menos de 500 personas trabajaban en ese proyecto y de allí ya había categorías, porque había quien los mandaba, quien llevaba las bolsitas, quien ponía los nombres a las bolsitas, y quiensabe que le hacía a todo eso...... nosotros les nombramos acá "tepalcates" toda la cerámica destruída la guardaban en bolsitas, y allá en el museo regional a un lado, había varias casas que ocuparon para que ... para ocupar mucha gente que fuera seleccionando y juntar las piezas. La verdad fue más, para mí, en mi concepto personal, fue más lo que se llevaron que lo que rescataron.... Bueno rescataron mucho eh.. pero allí desde el trabajador de campo, el que estaba allí, robó hasta los más altos. Entonces este.... Allí se empezó a perder el campo, porque toda esta región, toda, toda, absorbió la mano de obra del campo...Luego, a la par, le digo se vino la UDLA, que esa en 3 años la hicieron, arrancó, y también traía el mismo número y más yo creo que hasta más trabajadores que el proyecto, ocupó gente de San Andrés y de otras regiones, llámase Santa Clara, Tlaxcalancingo, San Antonio Cacalotepec, Tehuiloyucan, Cacalotepec, Acatepec, toda la región, Cuautlancingo, de todos lados, venía, si le comento que esta calle de paso, que en ese entonces no había carros, quiensabe de donde alquilaban los carros, las líneas que había, la Puebla- Cholula principalmente, iban a traer a los trabajadores, pero venían... así de trabajadores para mano de obra. Pues si pues les convenía, si en su pueblo ganaban 50 pesos 60, al campo, que era, aquí les daban 105 , 
según la categoría que usaran, en la universidad pues a los albañiles, a los... en fin les pagaban más pues...la gente fue abandonando el campo...

C: ¿Y usted cree que eso también se vinculó a la falta de apoyos al campo?

F: Mire, el gobierno nunca, es mentira que de apoyos al campo, los gobiernos saben que en ese entonces nuestro ejido hoy es lo que ocupa Angelópolis, y parte de acá que es muy poquito y parte que se está vendiendo ya todo eso pues.... están en obra en Santa Clara Ocoyucan, que colinda con San Andrés, entonces pues da apoyos el gobierno, como por ejemplo que pone, yo te doy.. que se yo, 2, 3 marranos, dos hembras y un macho que hay que regresarlos de nuevo, pero el comisariado ejidal aquí se los da a sus cuates, nunca se los da a la comunidad y BANRURAL y todo eso a través del comisariado ejidal aparentemente esos son los apoyos que dan .. ahora, les voy a comprar un tractor, de una cooperativa, se les hace la cooperativa, no se pusieron de acuerdo, se deshace la cooperativa, falta de organización, falta de criterio, y el gobierno pues que dice, yo ya cumplí, pero no los educa primero.... Ora, les da dinero, pus es para emborracharse, para todo, ...eh... el apoyo nunca ha llegado, o sea directo, entonces....la creación de empleos, pues tampoco, es mentira, entonces todo tiene un precio...

C: Y la industria... ¿en ese entonces llegó la Volkswagen?

F: Eh..la VW llegó, antes....la VW llegó como en el sesenta y tantos, pero la VW empezó con poco, y... de aquí hay poca gente trabajando en VW, principalmente hay de San Pedro Cholula, de Cuautlancingo, que fue donde se asentó, fue jalando mucha gente, en fin... nadamás que por ejemplo la VW vino pagando bien, trajo mentalidad de VW, más que de VW de Alemania entonces por ejemplo el que estaba en ... yo no trabajé, pero los comentarios, no dejan de ser comentarios, no?, entonces los que estaban en fundición para que rindieran más les daban medio kilo de plátanos y un litro de leche, aparte del comedor industrial que les daban, pero pues todo... no estamos preparados, no estamos preparados, porque me comentaban que no se tomaban la leche, porque no les daban a todo el trabajador sino creo que nadamás a los de la fundición .. no estoy bien enterado si fue a todos, pero la gente se ponía a echar volados porque...."mi leche o tu leche"... sale $;$ y había quien salía con dos o tres litros de leche... después la gente urdió, tomaban la leche, no se la acababan la tiraba a la coladera, agarraban el cartón, y se sacaban la pintura o cualquier pieza, entonces la VW lo notó y optó por quitarles la leche... El comedor, entraba la gente, les daban la pechuga o la pierna de pollo, o lo que sea, lo que aquí le nombramos el pan las tortas, se la aventaban de uno al otro, de un lado al otro, la carne y eso, entonces optó por reducirle su menú, en menos proporción, calidad y cantidad,también, entonces ahí vemos, la gente le falta educación, somos un país subdesarrollado, el día que tengamos un desarrollo total pues es otra cosa no?

C: Y ¿hacia donde más usted considera que la gente de San Andrés se movió para tener más ingresos?

F: Mire, la gente de San Andrés no se movió, la gente de San Andrés se movió a partir de los años ochenta, porque a hoy en día, en el 2009, ya hay varios profesionistas, mucha gente estudia, y anteriormente no...

C: Los padres ya se preocupan por la educación de sus hijos..

F: Más que de los padres,...

C: por pagarles la Universidad

F: Pues no pagarles... y si no, la gente de San Andrés tiene un gran problema, se siente autosuficiente, mmhh.. como ejemplo le voy a poner un caso, en la actualidad todos tienen casa, todos tienen terreno, y ahorita la gente vive de que va vendiendo... pone un negocito o se va a trabajar de lo que sea, un oficio, cualquier cosa, pero así así de que tengamos un área productiva en San Andrés, no la tenemos, no tenemos mercado, no tenemos agua potable, porqué? Porque se argumenta que tenemos pozos, no la necesitamos, en fin... entonces eso ha mermado el desarrollo de la población, la falta de criterio, pero más que de criterio, de educación, si porque aquí no hay gente emprendedora, ahí va viviendo, el que es mesero es mesero, el que es albañil, es albañil, el que va a la fábrica es fabricante, y así.... Al fin y a al cabo tienen su casa, tienen su terrenito, y si no, pues, ya se va acabando de que van vendiendo los que tienen, y si usted tiene casa grande, por ejemplo yo vivo ahorita, yo....pus tengo dos hijos, y si no tengo más, pus aquí los acomodo, y si tienen más pus ya los van acomodando y ya se va haciendo así, pero ya no es el pueblo de antaño que era, la población, pero es por la falta educacional.

C: Pero ahora que ya hay más profesionistas ... ¿que deciden hacer ellos?

F: Emigrar, emigran a la ciudad de Puebla, a X lugar donde encuentren trabajo, en fin, pus es como la VW, la VW alberga los primeros trabajadores se trajo la planta del estado de México se trajo varios de allá, hay gente de Chiapas, de Tabasco, de Oaxaca, en fin...en ese entonces la VW era la panacea, ehh... era el boom; que digamos acá se inició mucha gente y ya se quedó ....y así por el estilo, acá San Andrés por ejemplo, ¿en qué se puede emplear un profesionista? Tiene que migrar..

C: Acá el municipio contrata... ¿tiene como uno de sus objetivos contratar profesionistas de San Andrés?

F: Pero no es primordial, casi...vamos a hablar que tiene... si son 100 empleados que tiene, vamos a hablar que tiene 30 por ciento de San Andrés, empleados, hablo yo de barrenderos, de basureros, de todo eso, mmhhh, pues la cabecera municipal y juntas auxiliares, diga que tenga el 50, en el aspecto administrativo ha de tener un 20 por ciento. Porque y hasta eso, el 20 por ciento porque es nepotismo el que hace, acomodan a familiares, amigos, en fin... Entonces esto es un tanto molesto porque si gana el partido del PRI le meten gente de la ciudad, no se deja tanto el partido del PRI, aclaro, ya agarra más gente de por acá o aunque sea ve quien pero él la contrata, en cambio por ejemplo, ahorita a los doce o quince años que lleva el partido Acción Nacional, trae a gente que el partido le impone. Los puestos principales claves, si tú eres el presidente, pero este es el que va a ser de obras, este es el que va a.... tú tienes tus regidores de la población, ¿Qué representan? yo tengo mi regiduría, ¿Ah sí?, ¿Qué llevas? ..Obras públicas, pero el director de Obras Públicas es uno que viene de Atlixco, que viene de Puebla, o es otro que ya estuvo militando en el PAN, el secretario es el amigo, el 
compañero del partido del Comité Ejecutivo Estatal, o sea... lo que se ve en lo grande se ve en lo chico...así es, entonces, ¿qué quiere decir? Que no hay un despegue. Ahora, que San Andrés ya creció, a lo mejor tenemos la gente ya capacitada, sí, pero le falta el oficio, ... yo lo comparo, por ejemplo con la República, con el presidente de la República, que fue Fox, que ahorita es este Sr... les faltó el oficio político.... A Fox no lo dejaron hacer ninguna reforma, a él, su interés fue sacar al de los Pinos del Partido, y así fue acá, sacar el partido de los Pinos y ahí está, que le interesa el campo, ¿el campo porqué? Porque él puede, riego por goteo, que da muchos beneficios, pero es porque puede, pero que vaya con los pobres desgraciados aquí de las zonas marginadas, que les vaya a rascar un pozo.... Pues no, nomás no..éste, el del empleo, pus no en lugar de tener empleo, pus va patrás el empleo...

C: Y ese quehacer político, ¿en que ayudaría a la población?

F: Mire, yo siento que el quehacer político, es.... A lo mejor es bueno, porque ahorita el quehacer político que tienen acá, ya es generalizado, si yo la conozco... si yo conozco a la Sra. Concepción Martínez, se quienes fueron sus padres... es un ejemplo que le pongo... yo soy del registro civil y conozco a la Sra. Concepción, ella es vecina y todo la conozco, ahora, voy y saco mi acta certificada, porque ahora para todo es certificada, pero en mi acta dice Ma. Concepción, o Ma.

Concepción Juan, Petra, Francisca o lo que sea, pero siempre le hemos llamado Concepción, en su acta de nacimiento dice Ma. Concepción, yo la conozco....llega y dice: déme un acta, ... dice,.... No juicio ¡... rectificación de actas... Pues si toda mi vida en mis certificados está Concepción... todos sus papeles..... está como Concepción, no como Ma. Concepción, $i$ porque? Porque antes iba uno y pedía una copia certificada y decían: cómo te llamas....Concepción, y te la daban, no les importaba que fueras, Ma. Concepción, Petra, Francisca o Juana, y ahora no....Juicio... rectificación de actas... hay ancianos, que ya nomás es para darle a sus hijos, heredarles, donarles, les dicen Juicio, casi los están matando, entonces yo siento .... Si yo lo conozco, yo digo... pus ponle Juan, como se está llamando, si en el acta dice Juan, pues adelante y ya.... No...Juicio...claro, ese es mi criterio, el criterio que les han infundado allá es el que no,....correcto...correcto, pues sí...pero ya una persona de 60, 70 años, para que hace su juicio de ...Vaya, yo, yo me pongo en el plan de que en mi libro estoy como Venancio Felipe... y yo también fui empleado de la presidencia y nunca corregi mi acta, en la primaria, la secundaria, la preparatoria, la universidad estoy como Felipe y ahorita me sale mi acta como Venancio Felipe, ante Hacienda, tengo mi credencial de elector, como Felipe, y ya la fui a renovar y todo, no no no... para que hago juicio, yo lo puedo hacer, pero porque yo estudié Derecho y lo puedo hacer, pero para qué tanto enredo? Voy a dejarle a mis hijos con el papel más importante que es ahorita para identificación, la credencial de elector, voy a dejarles porque es para lo que quiero..

C: Y claro debe tener un costo..

F: Un costo, además de que el costo, uno va a ver un abogado, un viejito, un viejecito ya, si apenas muchas gentes tienen para comer, y un juicio de... no se los hace por menos de 10 mil pesos....Le digo a mi vieja, para qué me voy a hacer un juicio, yo voy a ser Felipe hasta que me muera y ya... saqué mis credenciales, tanto la vieja como la nueva la tengo ... $\dot{Y}$ cómo le hiciste? Pus engañando a la gente... esta es la vieja, esta es la que fui a sacar este año, ya era la 03, y está igual, con el mismo nombre, ... No que cámbiale....Ay vieja que va a decir lacta ni nada, déjala así es como está ya...de 60 años, un crédito, ya no te la dan, no te lo otorgan, ya nomás es para escriturarle a los hijos, .....que se va a morir Felipe, si pero me voy a morir como Felipe, no como Venancio Felipe ..... No no no, pero a la gente la ... entonces les falta oficio político...entonces, le digo, hay muchos factores y por tanto, todo ha venido bajando de calidad, pero es el precio... al desarrollo.

C: Esa es la otra parte que yo estoy analizando en mi estudio, todo ese desarrollo que se ha dado por la urbanización, que llega a San Andrés, por estar tan cerca ya de Puebla, porque la capital va extendiéndose...

F: Mire, yo lo decía, yo por ejemplo, usted conoce Puebla, el despacho lo teníamos a un lado de la catedral, en el edificio María, y a mí me daba más flojera ir a mis últimas clases a CU que venirme para mi casa, yo nomás llegaba al cerro de San Juan y agarraba la recta y ya... y allá, salir hasta ciudad universitaria, más tráfico, más....No aquí rápido, estamos más cerca, ahora con tanta vialidad que tenemos,

C: Es la zona más comunicada de toda la ciudad...

F: De toda la ciudad, llámese San Pedro, ahorita estamos más comunicados nosotros que ellos, porque ellos la verdad no tienen ni para donde echar su drenaje... Tienen que pasar por esta área a fuerza, así de simple y sencillo.

C: Si pues esto de la urbanización es como una arma de dos filos, $\_$usted cómo ve este proceso?

$\mathrm{F}$ : Mire la urbanización ha hecho que nuestra gente vaya cambiando, se vaya preparando y vaya adquiriendo otra mentalidad, el costo perder todos sus usos y costumbres y la ideosincracia, sí, aquí viven un señor de Monterrey, tiene una casa muy bonita, trabajador de Hilsa, compró hizo su casa, al señor le pasan a tocar para las cooperaciones y el señor nunca estái viene a dormir... sale la empleada, pus no está el patrón, y así no sabe nada de usos y costumbres...

C: Y ese es un ejemplo ....

F: Clave para todos los avecindados, todos los avecindados, ellos no saben, y anteriormente aquí por ejemplo, el rumbo de acá, la misa al santo más rabón, la limosna para San José, cuánto es? Diez pesos.... Que va a pasar una misa rogativa para .... que venga lagua, porque hasta eso hay, para la siembra, que empiece a llover, ... al avecindado que le va a importar que llueva o que no llueva, que tenga el agua potable, que tenga sus servicios, y lo demás le vale...

C: Y como ¿Qué beneficio han traído pues los avecindados? Si hay alguno..

F: Ninguno, el beneficio que han traído, que sea costosa la vida, más costosa, que los terrenos sean carísimos, que pues ya tenemos servicios, estamos dotados de servicios y todo, y que la gente ya se prepare...ése es el único beneficio...y ya los ven y ya... la gente ya no quiere quedarse tan estancada, que todavía faltan treinta años para ver ese estancamiento, que de frutos, de momento, no va a haber, pero para cuando esos treinta años lleguen, San Andrés ya se perdió, porque vamos a 
estar más llenos de avecindados, que los de acá. Le digo por esto, porque el profesionista que se va haciendo maestro, doctor, trata de salir, en cambio el avecindado ya viene, pero ya viene con cierta mentalidad, si es ingeniero ya trae trabajo, o ya viene o ya lo mandan de otros lados, pero ya tiene sus empleos ya tiene todo, a él ya no le preocupa,... $\mathrm{C}$ : Y en cuanto a esa actitud, que llegan y piensan que ya no necesitan de nadie, yo ya compré, ya tengo derechos... F: Ellos comprando, exactamente, lo que me rodea es para mí, haga de cuenta que es la misma ciudad de Puebla,... C: Pero yo como avecindado podrían no gustarme, las tradiciones, los cuetes, los animales..

F: Desgraciadamente, eso se va a acabar, ... bueno, a lo mejor los cuetes no, las fiestas, no, yo le comento anteriormente, del año 50 para acá, es cuando ya hay más uso de razón, de niño para acá, ...uh.. eran una de cuetes, por ejemplo el día domingo, hacen la gran fiesta como la que ahorita está en San Pedro, la famosa bajada de la Virgen de los Remedios, baja pallá....El día domingo aquí salen a invitar, el que va a ser una misa, los castillo, los cuetes, las flores, la alfombra... ¿usted ya vio las alfombras?, ¿ Los arreglos que se ponen?...todo eso salen a dejar las invitaciones, y hoy ya salen en carro, anteriormente eran caminando y en carretas tiradas por mulas...veía a las gentes con su "ceñidor", huaraches, calzoncillos...en ese entonces, todos de sombrero....hoy casi nadie ya usa sombreros, usan zapatos, carros, los únicos que van con la música son los encargados, truenan sus cuetes y ahí andan, realmente un mundo diferente al de hace 60 años que le estoy diciendo, de el año 50...Ahora, anteriormente, en el año 50, yo encargado iba, Sra. Doña Concepción, o Sr. Pedro, su hija va a ser la encargada de las flores y alfombra, le venimos a dejar la invitación, su diana, sus cuetes, muchas gracias le agradecemos, tocan cualquier cosa con la música, le agradecemos y vámonos...hoy no, hoy ya se hicieron de ... que les dan jugos, que les dan un sándwich, que les dan una torta en cada parada, y a la comisión y al mayor que ya le dan una botella, son las 10 de la noche y andan ya bien cuetes, es lo que se ha incrementado, el alcoholismo. Anteriormente por ejemplo, el que tomaba era el hombre...y en todos lados, yo me imagino, creo yo, la mujer no tomaba, y hoy han cambiado las cosas, las chavas felices, bueno usted se da cuenta, le entran y todo, y se ha incrementado y mucho gasto. Anteriormente era pues que la fiesta, que acá, que un jaripeo, una carrera de caballos, que quien va a montar los toros...ehh..una fiesta totalmente de pueblo, que la gente de acá, hacía su molito...hoy la gente hoy en día, casi nadie hace mole más que el encargado, porque la gente come como cualquier día del año, se va acabando, desapareciendo ... y porqué? 'porque a los hijos ya no les gusta eso, criar el guajolote, matar el guajolote, ora es muy fácil, cómprate un pollo, cómprate puras piernitas, pechugas, y de eso hacemos el molito, o si no, un pollo rostizado y ya comimos, ....y eso quien nos los ha traído, pues los avecindados...y las firmas extranjeras, transnacionales más que nada...pues ahí tenemos a un Burguer, ahí tenemos a un Mc Donalds,

$\mathrm{C}:$ ¿se establecen en los noventas?

F: No, el Mac Donalds este tendrá.... como en el 2000 y luego el otro el Burguer como a los dos años, esos son más recientes.

C: Lo que si ha sido ya como otra tradición de San Andrés, impuesta por la urbanización y por la UDLA, la calle de los antros...

F: Ah, ese es otro aspecto, anteriormente les llamaban Discotheques, y pues iba uno y siempre se ha manejado que... el baile, pero era más sano.... Y no había más que marihuana... eso es lo que vino a partir de la UDLA y anteriormente nomás eran tres, Discos, que eran el Bazar, que empezó oficialmente, eran a nivel nacional. Creo que el Armando Le Club, estuvo en... Acapulco, fue la primera Discotheque, y la segunda fue el Bazar, a nivel nacional, y esa la hicieron unos de Guadalajara, con el director de tránsito de Cholula, se asociaron 13 socios, para hacer esa discotheque, y les dio un resultado de aquellos.

Luego, la primera primera que estuvo fue el Tiffany's, luego fue el Bazar, no, primero fue el Bazar, luego el Tiffany's, ... luego ya ve la del Tio Wilo, luego ya se vino la Universidad de Puebla con sus líderes, pusieron el perro tartamudo, que la zorra de Fox, este... Midas y siguieron abriendo una serie de Discotheques, pero como abrían, cerraban, abrían, cerraban, y ya... hoy sigue habiendo muchas discotheques, pero más que discotheques ya son bares, tipo restaurant-bar C: Si esa es una moda internacional, porque ya discos, dificilmente encuentra una en la ciudad de México, ya todos son bares, lounge, ya son más pequeños,

F: Son más pequeños, más vicio, más drogadicción, porque yo me acuerdo que antes a las discos, llegaba desde toda una familia cuando querían divertirse, se salía que se yo, la disco empezaba 9 de la noche para acabar a la una dos de la mañana y ya era muy noche, hoy no... hoy el reventón como le dicen los chavos, empieza a las doce, una de la mañana, para que acaben a las 7 de mañana, si totalmente ya todo cambiado y pues lógico ya hay mucha droga, ya hay mucho desorden ... anteriormente lo que daban desorden pues eran los gringos que el desorden era de que ya cuetes, principalmente las chavas ya a la una o dos de la mañana, empezaban a hacer entre ellas su show, pero nosotros re divertidos no? Pero hasta ahí, y pues había marihuana y alcohol, pero eso siempre ha habido, pero no como ahora que anfetaminas, coca, pericazos, en fin ya de todo eso...

C: Y esa parte ¿que pasó ahí, como lo explica usted?, que no hubo respuesta de la gente, hubo aceptación desde un inicio...

F: Bueno hubo aceptación, por esto, porque desde que llegó la universidad, fue una derrama de dinero, el gringo, siempre ha sido muy tacaño para comer, él con una cerveza y una hamburguesa era su comida.... Si hubo gente que se dedicaba, recién de que se fundó la UDLA, la bajada de la pirámide, entonces era la entrada principal a la universidad, se dedicaba a juntar envases y botes que iban tirando en el camino, este... de aquí desde San Pedro hasta la entrada de la UDLA, y acá, principalmente los que estudiaban pintura, y los de antropología que eran los más extravagantes, aquí alquilaban una casita de adobe, y principalmente si era de adobe y piso de tierra era mejor, se compraban un petate, petate, fue el hippismo en esa época, un derroche de dinero, mientras más gruesos fueran los huaraches, traían sus pantalones de 
mezclilla, de esos como overol, unos anteojitos tipo este... Beatles, de esos chiquitos, pero andaban superestrafalarios, pero era los que dejaban mucha lana. Alquilaban casas y pues a la gente lo que querían era sacara dinero, lo que les pedían daban, y la gente aquí muy feliz, muy conchuda, porque el gringo les dejaba una televisioncita así para esos años, en México, era un lujo tener una televisioncita portátil, la dejaban regalada, la bicicleta, sus bicicletas, abrigos, zapatos, y venían al próximo verano, se sentía felíz, si le pagaban eso, nunca hubo una queja.....

C: Y se aprendió a ser tolerante con todas esas costumbres...

F: Mire se aprendió a ser tolerante porque la gente siempre aquí ha sido convenenciera, y le voy a decir porqué, porque yo tuve un ejemplo muy claro, cuando, aquí no había escuela secundaria en esos años y la gente, tomó la presidencia, yo estaba trabajando ahí en esos años, que quería su escuela secundaria y una de las que iba a la cabeza dijo: usted señor presidente anda que no tiene para la escuela secundaria, a todas esas discoteques esos negocios si los dejo pero a cambio me hacen una escuela asi y asi a como usted la pida y la quiera, si no, no hay discos...... Están equivocadas señoras, aquel como todo comerciante, como todo empresario, viene y pone su negocio por eso paga un impuesto al ayuntamiento y el ayuntamiento le da una licencia de funcionamiento, porque? Porque el paga a Hacienda sus impuestos .... el jamás va a decir que se les haga una escuela... ustedes que tuvieron los hijos..... No pero es que si usted se pone así no se pone el negocio si no nos hace una escuela, ...y así es la gente de convenenciera.

Entonces siempre ha sido convenenciera...que si llega el día del niño...pídanle a los antros, ...que les regalan galletas, dulces...la gente es feliz......, no, que pague impuestos y dejemos de pedir, como actualmente se hace ahora porque hoy si ya pagan impuestos, porque anteriormente a nosotros nos pedían, nos exigían, denos usted una carta que somos del comité de padres de familia y queremos que nos den para el día del niño, no... si los padres son ustedes no son ellos, no pero están asentados acá y tienen obligación, ....la gente es convenenciera...entonces por eso no se impuso nunca, dejó que fuera creciendo y creciendo, ... que no le molestara sus intereses a la gente, que no diera nada ella y que tuviera bien a sus hijos en la escuela, la gente era felíz, así, así era San Andrés....

C: $Y$ esa otra actividad reciente de la construcción de departamentos y cuartos para renta

F: Eso siempre ha surgido desde que llegó la universidad, y ha rentado el que ha tenido centavitos, principalmente los aledaños a la UDLA, por acá, poco se da la renta, por esta zona: La zona de la UDLA si se da eso, porque qué se yo un cuartito al estudiante con su camita y nada más, es buen dinero, si, o sea que eso se incrementó del año 70 para acá y hasta eso últimamente ha coptado estudiantes porque cuando se incrementaron los estudiantes aquí casi la mayoría de estudiantes vivían en San Pedro, querían Banco a San Pedro, todo era San Pedro,

C: Si pues todos los servicios que siguen estando ahí..

F: De diez años a la fecha, ya no es San Pedro, ¿ porque? Porque San Andrés tiene bancos, tiene dormitorios, la UDLA tiene dormitorios, todo todo ya es otra mentalidad...

C: Que, eso podría verse como que se está creando una autosuficiencia...

F: Exacto, exactamente...

C: Sin embargo el centro..... no es autosuficiente, se están creando puntos de desarrollo, nada más

F: Si, por ejemplo a nivel comercio, está por los suelos, a nivel población, porque vamos a hablar, Angelópolis, es San Andrés, pero es autosuficiente, en todo y por todo...

C: Pero la gente de aquí ¿acostumbra ya ir a la MEGA de Angelópolis?

F: Sí, pero....

C: ¿O sigue yendo a San Pedro?

F: Bueno, va al mercado a traer sus chiles y jitomates a San Pedro, a la mejor ya va a la Mega, porque he encontrado a alguna que otra gente, incluso en Liverpool, Fabricas de Francia, ya las he encontrado, si no compran mínimo ya van a ver ya, ya va cambiando la mentalidad..

C: Y a Mac Donalds o Burguer

F: Va, pero muy escasa...

C: ¿Pero a los bancos sí?

F: Los bancos si porque ya es una necesidad, aunque va poca gente, le puedo decir que hablo yo del $40 \%$ de la población de San Andrés hace uso de los bancos, más no porque es gente de escasos recursos, es gente que trabaja, aunque tiene bienes, tiene su casita, uno o dos terrenitos, pero, no tiene liquidez, el recurso suficiente para guardarlo: Los bancos lo saben, va uno de San Andrés a pedir una tarjeta de crédito y al momento se la dan, saben que si tiene para pagar, porque tienen bienes, que no tienen dinero circulante, pero de que hay cierta movilidad si la hay,

C: Las familias que rentan quizá estén enfrentando algunos problemas que usted conoce..

F: Pues tienen el problema del agua, es un problema y no, porque? Ráscale más al pozo y te da el agua que quieras, El problema del drenaje porque no es lo mismo, a que en esta casota, somos 5 de familia a que sean 20030 ,

C: ¿Y la venta de pipas de agua?

F: La venta de pipas hasta hace unos años, hasta el año 90 se podría decir que era clandestina, hasta que hubo problemas con la venta de agua de pipas entre los mismos vecinos, porque muchos vecinos se oponían a la venta de agua,, pero más que eso era un roce social entre familias, entre vecinos, entre ... envidia, la discordia siempre ha existido, .....pero a partir del año 90, más o menos, la SEMARNAT antes era la SAR, ya les cobra un impuesto a los que tienen norias, o pozos artesanales de dónde sacan esas pipas de agua, les cobran impuestos, pero pus ya saben que el agua, la sacan y pagan ese impuesto. La mayoría de pozos que están cerca de la UDLA son los que venden, ya tiene su permiso, entonces por eso, ya los chismosos los vecinos que no querían, pues los que se oponen en cierto modo a que haya pues otro desenvolvimiento, ya se detuvieron, ...... 
C: Como le decía, toda la urbanización yo la veo bastante contrastante, en el lado del periférico, y en la avenida Zapata, con construcciones para gente acomodada...

F: Pues es que esos terrenos, en el periférico y todo eso ahorita compra gente que tiene dinero, porque depende la zona como esté clasificados, en el $\mathrm{H} 1, \mathrm{H} 2$ o $\mathrm{H} 3$. Si es residencial...

C: ¿El centro que zona es?

F: El centro pues es centro... Yo tengo un precio hasta esta calle, hasta la 9 , yo salgo de calle a calle, de allá para acá tiene un precio, a la 15 otro, y de la 15 para allá otro. Del centro a la 4 o la 6 ote y pte, también tiene un precio, de la 6 a la 10 ote. Pte. Otro precio y de la 12 a la 14 que es la Udla tiene otro precio más caro.

O sea que del centro para allá a la 6 ote, pte, de la 6 ote pte, tiene otros precio, pero de la 12 a la 14 es el más alto.

C: pero, ¿que no es un centro también histórico, y eso incrementa el precio?

F: Ah claro, pero pus no debería ser caro, pero lo han hecho más caro, principalmente los avecindados, ...vamos a suponer, la zona de la pirámide donde hicieron la pista de tartán, de pasto sintético, ahí está pero carísimo, claro, ahora en día ya el INAH les pone los parámetros, no se qué, pero el ayuntamiento les dice nomás no construyas más de dos pisos y haz tu casa, y hasta ahí, pero de que se ha vuelto caro, se ha vuelto caro.

C: Ahí ¿no sabe usted si hay algún decreto?

F: Hay un reglamento.

C: que haya expedido el INAH, en el centro, no en la pirámide.

F: Si lo hay, el INAH en toda esta zona, debemos sacar permisos para construir, si, pero nadie hace eso. Sí, porque me vienen a hacer mi sondeo, y si me encuentro un metate, un lo que sea, me la para.......si aquí no le digo lo que encontré?...

A mi hijo ahorita en la prepa allá en Puebla, le acaban de decir algo y me pregunta: Oye papá ¿es cierto que si el INAH descubriera todo lo referente a zona arqueológica, San Andrés y San Pedro desaparecen? .. si, los dos están asentados sobre asentamientos prehispánicos, pero yo siento que hay más acá, porque aquí era adonde había mucha agua... San Pedro no había agua, donde estaban los ríos era de aquí y todo donde agarra la UDLA, que eran los manantiales. Los manantiales, le digo que cuando corría uno hasta se movían, eran ciénegas, acá, ni se diga, aquí a tres calles, también, pero eran ojos de agua que deveras salía el agua, todo eso se fue secando a partir del 66, de los 70 .

C: Y ahora fijese a partir de los ochentas que el INAH empieza a expedir decretos, por ejemplo lo que es patrimonio de la humanidad, la zona de las pirámides, los centros históricos y los gobiernos locales comienzan a hacer toda una reestructuración, a remodelar, porque se trata ahora de rescatar su patrimonio, eso también incrementa el precio...

F: Incrementa el precio, exacto, yo por ejemplo veo aquí esto, aquí aquí San Andrés está ahorita más caro y preguntaba ¿porqué?, dice bueno, es que aquí, usted compra terreno y si bien es cierto que está antropología y está todo, usted puede hacer su casa como usted la quiera no le dicen nada, Y EN Puebla, compra usted una casa y no le puede usted hacer más que remodelaciones, porque no puede usted tirar, y eso es lo que se abarata, bueno supuestamente es lo que dicen los arquitectos. Si yo veía, yo comparaba, usted conoce Puebla, una casa en Analco, lo que es el jardín de Analco, eran 600 metros y pedían 1800000 pesos, construcción vieja, lógico que van a remodelar los cuartos porque el INAH no lo va a dejar tirar nada. Entonces que a eso se basa la gente.

C: $\mathrm{Y}$ a veces la remodelación cuesta más.

F: Cuesta más más caras que levantar un muro nuevo, entonces eso es

C: Una explicación es que el INAH se ha metido más en Puebla que acá.

F: No pues acá no le interesa, que le van a interesar puras casas de adobe,

C: si y ya no tiene adonde poner tanto que ha encontrado, el museo de antropología está lleno.

F: Pero le digo Cholula, yo creo que todas las casas tienen, y cuando rascaron la pirámide se llevó más desde el trabajador más insignificante hasta el de arriba, que lo propio que hay en el museo de antropología.

$\mathrm{C}$ : En realidad si se ve pobre este museo...

F: Mire yo fui de niño, ahora $n$ i me interesa ir. Pero en ese entonces le digo que ni en cuenta. Cuando vino la UDLA, principalmente los de antropología, todo todo eso, hasta los terrenos de por acá, se ponían iban arando surco por surco, esos pedacitos negros de obsidiana, los juntaban, todo se llevaron $i$, si pus ellos llegaron en el $68,69,70$, el decreto creo que salió hasta el 80 por ahí. Bueno en Puebla, cuantas casas coloniales no se echaron, pero auténticas joyas,

$\mathrm{C}$ : Y a partir de los 70 s ya los pararon...los del INAH

F. son caserones muertos, que no producen nada, hasta la gente se ha muerto porque se les ha caído encima, no pues es que no es igual que estén pagando 300 pesos de renta a que se vayan a un departamento a pagar 3 mil... y prefieren vivir ahí como sea

C. Y ahorita, así como están las cosas, si uno quisiera definir a una sociedad sanandreseña. ¿Usted como la definiría?

F: Bueno yo la definiría con sus alcances, porque la verda, la gente, la sociedad sanandreseña se conoce por sus fiestas por su folklore, pero yo la definiría a una persona muy apática. La llama uno: ... ven que vamos a hacer una serie de conferencias o vamos a hacer un grupo de aerobics, no van, todavía hay gente muy conservadora. Principalmente la gente de 40 años para atrás, no se prestan ni hombres ni mujeres eh?, o sea aparentemente no quiere salir de su terreno, no quiere perder sus costumbres, pero no hace nada por recuperarlas, pero tampoco hace mucho por superarse. Yo la siento como una gente pues no tímida, sino hasta que tiene miedo. No hoy los muchachos en día ya se prestan,

C: Quizá venga otra generación como él(su hijo de 17 años), por ejemplo, cuando tenga treinta y tantos años.

F: Si a eso voy, que nuestra gente por ejemplo aquí en San Andrés, no hay una casa de juego, de diversiones, no hay un cine, no hay una sala de espectáculos... 
C: ¿por la cercanía con Puebla?

F: por la cercanía con Puebla, con San Pedro y porque su gente es de que ¿cuánto cobran? Ah, no está muy caro, y hasta la juventud...ven, mejor vamos a echarnos una chela: Aquí no se si se ha dado cuenta, aquí lo que es San Andrés, las tienditas venden cerveza, en botella y se las toman en la calle o ahí mismo, y nos da otra señora, nos da otra y eso cuesta mucho trabajo. Y eso pasa en Tlaxcalancingo, Acatepec, Tonantzintla, San Luis Comac, que son las juntas auxiliares. C: quizá así estén muy agusto ¿no?

F: Yo le llamo la ideosincracia de la gente de acá.... Ora pongan un mingitorio, pongan unos baños, simplemente en su casa, o aquí déjenme vender en mi tienda, pero no no quiere la gente, pero se sienten feliz de que la gente los vea chupando, que los vean....le digo es la ideosincracia de la gente. Para mí que siento que si van a un bar, o a un botanero como le nombran hoy, piensan que pagan mucho,

C: No existe esa costumbre de pagar por los servicios

F: Exactamente, exactamente, sienten que pagan mucho

C: Y así cómo ve usted todo esto, yo intuyo que en su caso se ha dado de otra manera, usted ha visto toda esta situación, ha tenido esa sensibilidad para percibir por dónde hay que caminar y han aparecido otros deseos de hacer las cosas de
diferente manera...

F: Bueno...y yo tuve otros deseos, los realicé, los hice, porque yo soy yo, yo tuve otras ambiciones, fui campesino, se ir al campo, se todo, ... que ya dejamos todos esos asuntos, hoy ya nos dedicamos que al negocito y de ahí vamos viviendo, hay que vivir con los hijos, acorde con ellos. No los deja uno ser chavos banda, que sean muy reventados como dicen porque no debe de ser, pero que si que vayan acorde con el tiempo.

C: Usted ¿los deja que vayan aquí a la 14, al bar...?

F: Van a ... de vez en cuando

$\mathrm{C}: ¿$ A usted no le incomoda?

F: pus me incomoda que sean viciosos, que sean irrespetuosos, simplemente que se den a respetar y los respetarán, y no son santos, que se tomen sus tragos, y que vengan bien y ya, si pues tengo dos hijos una que está estudiando odontología allá y este que está estudiando la prepa, entonces... les damos la oportunidad porque yo también siento que ya no es mi época en la que yo me crié, ya son otros tiempos, hay que vivir acorde como son, pero tampoco sin que se revienten, vaya esa es mi idea. Y mi idea es estudia, si no te gusta un negocio y adelante, porque hoy deja más un negocio, que una
profesión,

C: En este momento...

F: Si, siempre, ya los negocios de los años ochenta para abajo, o los profesionistas, ya no, de no ser que sean unos especialistas, que se hicieron de buena reputación, una buena cartera y ahorita ya son... pero profesionistas jóvenes y que tengan un futuro prominente, no, si no es que están en finanzas, están en hacienda, están en la federación, están en el seguro en el ISSSTE, esos son los buenos, de ahí en fuera cuanto médico, abogado, contador, todo, ingenieros andan en taxis, andan de choferes en los servicios públicos, olvídese, .... yo le digo porque tengo servicio público y ahí me van a ver,

C: Entonces usted ahorita ¿cómo se ve aquí en San Andrés, con todas las actividades que ha realizado, su profesión, ahora sus hijos?

F: Yo me veo, como una persona si no realizada, he tratado de salir adelante, con otros medios ya no del campo, de la producción, con otros medios, no vivimos bien...pero tampoco vivimos mal,

C: Este modelo de trabajo que usted ha implantado en San Andrés, me imagino que coincide en que la gente debería hacer lo mismo..

F: Exacto, pero es lo que le digo, aquí cuando nöes el alcoholismo, el conformismo...porque como son casas grandes ... ya ahí viven todos, hacen más cuartos, y al hijo ya se le casó un hijo, hacen otro cuarto, y ahí la llevan, es conformismo y el que tiene, eso va a aguantar para mi criterio, dos tres décadas, más no se puede, se acabó

Por eso le digo en 2, 3 décadas esto se acabó...

C: Cuando dice se acabó ¿a que se refiere?

F: Ah los espacios, para vivienda, tener una vivienda que se yo de $20 \times 20$, se acabaron las casas grandes, porque hoy en día, van a seguir vendiendo o simplemente con mis hijos y mis nietos se va a ir se va a ir,

C. Todos esos terrenos hacia San Rafael, ¿no hay empresas?

F: No casi no, ya son pocos, si usted se sube a la pirámide va a ver, que ya es una manchita muy pequeña, entonces la mancha urbana ya se metió, si San Andrés la gente hubiera comprado cuando vino la UDLA que era barato, pus en ese entonces la Ha. era de a mil pesos, sobre la recta, de mil pesos era un chorro de dinero, se hubiera venido para acá, no a la gente se le hacía carísimo, pero super caro, no la gente que vendía allá por la recta, compraba carros, vacas, camionetas, le alcanzaba con 100 mil pesos para muchas cosas. Si la gente de la ciudad se hubiera venido para acá, San Andrés ya se hubiera acabado... pero como hubo opción de comprar más barato por otros lados de la ciudad, pues muchos se fueron
para allá

C: Desde luego Don Felipe, ante el avance actual se requiere organización, ¿cuentan con alguna organización de vecinos en San Andrés?

F: No le digo a usted que no hay ninguna organización. Antes, por aquí pasaba el encargado de la velación al Santísimo, pero ahora ni eso. No hay organización, no hay grupos, nada de música, deportes..

$\mathrm{C}: \mathrm{Y}$ ¿en qué momento colaboró con el Municipio? 
F: Del 84 al 87, la gran diferencia es que ahora ya hay recursos en el municipio, a partir de la modificación al Artículo 115 constitucional, se originan

C: ¿Qué atractivos son los que encuentran en San Andrés los avecindados?

F: Pues, que es un pueblo en calma, cuenta con servicios, la gente es amable, es un pueblo con vida y el agua que es muy buena.

C: ¿Qué hace falta en San Andrés?

F: Más pobladores, más comercio.... Que se haga un mercado, porque eso atraería al comercio.

C: ¿Cuál es su opinión de los avecindados?

F: La opinión tradicional es que van a acabar con las tradiciones, y la personal, que los avecindados ayudan a superar a la gente

C: En cuanto a la seguridad...

F: La seguridad la mandan adonde se necesita......ahora está en Angelópolis. Anteriormente, en la administración pasada hubo mucha seguridad acá, en el centro, había policía montada y todo eso, ahora la han mandado a Angelópolis

C. Seguramente porque tienen que cuidar sus intereses..

F: Pues allá está el Tec de Monterrey, el parque de diversiones, la Ibero, ...

$\mathrm{C}$ : Y ¿cómo ve usted la construcción del periférico?

F: Un beneficio. Pero le digo a usted, el avance de cada población tiene su precio....

$\infty$

- ENTREVISTA A FUNCIONARIA PÚBLICA

Fechas: Noviembre de 2008 y Mayo de 2009

Lugar: San Andrés Cholula

C: Es muy notorio al llegar a este municipio percibir que está interesado por un proceso modernizador. He visto carteles ubicados en varias partes, inclusive allá en Puebla por la zona de Angelópolis, en donde hay una mezcla que se observa de lo moderno y lo tradicional, sobre todo con el mensaje de que San Andrés lo es todo y que conserva tanto la tradición como está abierto a todo ese proceso modernizador que además se viene observando rápidamente.

No claro, esto de la conurbación aunque no se quiera y como tampoco hay un reglamento de lo que es construcción de lo que es todo esto, entonces también eso no permite tener esa modernización no? No permite también tener un crecimiento regulado al no haber reglamentos no? Eso es lo que está pasando y también interés de ciertas autoridades que cada administración sus enfoques son distintos, entonces si les interesa lo moderno pero a esta administración le interesa estas cuestiones del arraigo, de la identidad, del mundo de las tradiciones con una serie de proyectos culturales no? O en favor de la conservación del patrimonio cultural

C: En ese proceso modernizador digamos que ustedes eh.. ¿lo comenzó la administración anterior? O ustedes...

Es un proceso que se ha venido ya dando desde.la primera administración Panista, de un cambio, de todo lo que es la cabecera, como pavimentación, hubo más luz, hubo obra de drenaje en las calles todo eso y el crecimiento urbano que se viene dando de forma irregular

C: O sea, como prioridad sigue siendo también la atención por ejemplo a obras de drenaje y para mejorar la calidad de vida de la comunidad.....

$Y$ eso trae también como consecuencia una especulación de la gente, la gente se quiere venir, quiere poner antros, quiere poner restaurantes, quiere poner negocios en esta región no?

C: Eh, digamos que entre los cambios más visibles está toda aquella zona de Angelópolis, que me imagino continúa con el conflicto de los límites territoriales...

Sí,

C: Después, todos estos desarrollos urbanos, habitacionales, que llegan hasta la UDLA, después esa avenida que es la 14 ote., que ya casi es una avenida porque se ve la fisonomía de todos los negocios, incluso también el diseño de la calle, en la noche me imagino que la iluminación. Por ejemplo hay una serie de anuncios espectaculares con luz que están toda la noche...

No le digo que por la falta de reglamentos porque si hubiera una reglamentación de imagen urbana eso no podría estar en un centro histórico, entonces ahí también por la falta de atención no?

C: Cuando usted dice centro histórico, ¿considera que el centro histórico tiene que ser hasta los límites con la UDLA o es esta zona donde esta ubicado el municipio?

Hasta los límites, hasta una parte de los límites, porque ahí hay mucha población de San Andrés. De ahí hay un área, de donde está Rosendo's para allá son totalmente ajenos son terrenos y han puesto muchos negocios no? Pero de Rosendo's para acá pues ya es el centro histórico. 
C: Digamos que la zona del barrio de Santiago ya es otra delimitación ¿o todavía la consideran parte del centro de San Andrés?

No todavía

C: Porque la cabecera municipal, los límites llegan hasta el periférico ¿o no?

Casi hasta periférico, pero la población concentrada está cerca de los barrios, los ocho barrios que tiene San Andrés. Y hay un área pegada al periférico que no, está viviendo gente de San Andrés.

C: Bueno esa es la otra zona que también me llama mucho la atención, hay muchos edificios ahí de departamentos pero de tipo ya moderno, residencial, casas igual y son demasiados $i n o$ ?

Sí, precisamente por lo que le comentaba la especulación, lo que ha provocado es que muchos inversionistas vengan y hagan condominios para estudiantes les den todos los servicios con internet, cuartos amueblados y todo esto no?. Entonces porqué? Porque lo ven como una demanda no? Y Así ha sido esa zona.

\section{C: Digamos que la UDLA ha sido un detonador de todo esto}

Por supuesto

C:Y luego a eso se suman las inmobiliarias y ¿qué otros actores están involucrados en este proceso?

Todo lo que es ahorita por ejemplo, la industria restaurantera también, pero más como restaurant-bares no?, esos han sido demasiados, demasiados, están pues ahora no nomás están en la 14 sino que se están viniendo más hacia el centro..

C: El municipio aquí en sus oficinas no tiene a un encargado de ver todas esas cuestiones de permisos para que se establezcan los bares, los restaurantes...

No si lo hay y tienen una reglamentación, pero al no haber un reglamento comunicado donde delimite zonas históricas, donde tenga que ver también cuestiones de la infraestructura rural urbana, pues obviamente que les salen propuestas. Entonces se otorgan permisos

C: Aquí San Andrés como zona histórica, prehispánica, tiene algún reconocimiento oficial?

$\mathrm{Si}$, hay un decreto, hay un decreto federal, donde delimitan lo que es la zona arqueológica, de Cholula, ahí marcan Cholula y parte de eso es San Andrés, y manejan ciertos puntos con una extensión, no recuerdo en este momento de cuántas hectáreas, si quiere le localizo el decreto y le paso los datos para checar no? .El problema de esos decretos es de que no hay reglamentos municipales para apoyar esos decretos federales. Entonces de nada sirve que haya esos decretos si no hay una reglamentación municipal que sirva para la protección de ese patrimonio.

\section{C: Digamos, que se está trabajando en eso...}

Mmmh...En hacer un reglamento...Sinceramente yo no creo, la misma INAH ni conoce la estructura ni conoce las tradiciones de la región no?

C: $\mathrm{Si}$, la otra parte que me parece menos modernizada es el zócalo y no sé y ¿serán cuatro cuadras a la redonda no?

Exactamente pero es pero es que como está, por ejemplo la 14, está la Univ. De las Américas, toda esa área viene acercándose poco a poco

C: Si porque ya el "Pulke-para2" ya está muy cerca...

Exactamente, y aquí en el centro histórico para empezar ya hay más construcciones ya hay más cosas no? Entonces como que no hay tanto para poner o la gente no ha querido...

C: Si, cuando yo estuve haciendo mi investigación anterior entrevisté a una persona que estaba en el local este que se llama Palawesh, y el me decía que tenían por ejemplo un proyecto, la organización más bien de un comité prodefensa del zócalo o comité pro-defensa de los centros históricos, pero es una persona de fuera y creo que está integrado por avecindados. Eh ¿usted no sabe de la existencia de ese comité?

No de ése no, hay algunas otras asociaciones civiles que estan trabajando en defensa del patrimonio, una de ellas es ProCholula, ese si está integrado por gentes nativas, y también interesada en la cuestión cultural no? Está integrada por fiscales, párrocos. Anteriormente yo formaba parte de ese comité, pero ellos si realmente tienen ese enfoque, el rescate del patrimonio, la defensa del patrimonio cultural, tanto tangible como intangible no? Pero no se ahorita como estén trabajando, estaban presentando un proyecto sobre la protección de monumentos históricos, para prevenir el robo de arte sacro, pero pues es una millonada, es un proyecto que presentaron y que sale en 240 mil dólares.

$C:$ ¿En qué consiste el proyecto?

Este es un proyecto que consiste en colocar "chips" a las pinturas pero si se me hace una cantidad....y estamos hablando que solamente sería para 10 templos. Entonces Cholula tiene infinidad de templos, y solo se contemplan 10 piezas 
importantes, y en cada iglesia tenemos.....aquí el cuadro del Juicio Final, las imágenes, los retablos, es demasiado, no sería suficiente no sé, entonces...

\section{C: ¿Cómo que es inviable...?}

Yo lo veo totalmente inviable, aquí se requiere más capacitación con los fiscales también no? Desde la colocación de protecciones en ventanas, las puertas que funcionen bien y sobre todo hacer conciencia con los mismos fiscales que muchas veces, eso lo hemos visto que quienes tienen que ver en todo estos son ellos.

\section{C: Están coludidos...}

Sí porque cómo van a saber y quién les va a abrir para sacar unas piezas de esas dimensiones, o como saben donde está o como saben cómo abrir, pues porque están involucrados. Entonces yo creo que tendrían que hacer conciencia, mucha conciencia con la ciudadanía, darles cursos de capacitación, sobre el patrimonio no?

El INAH tiene ahorita un proyecto sobre capacitación y cómo prevenir el robo de arte sacro, pero también ellos tienen que hacer conciencia desde hacer los catálogos, hacer los inventarios completos no? Pero tiene que ser la misma iglesia porque otra de las cosas es que difícilmente permiten que lleguen otras instituciones no? Y cómo el problema acá es de los fiscales que cambian año con año y el proyecto se tiene que ir a mas de un año para poder realizar inventarios, y catálogos detallados.

C: Esa es otra de las cosas que por ejemplo esta persona que mencioné, me platicó, y me puse a pensar en que a lo mejor hay algunas asociaciones, ONGs....

Hay algunas ONGs que surgen pero no tanto para apoyar lo del patrimonio, sino que surgen en tiempos electorales y se nombran protectores saliendo en defensa del patrimonio no?

C: Por ejemplo aquí, no me había dado cuenta de que cambiaron el empedrado alrededor del zócalo.. Y esa persona me decía: fíjese que quieren levantar el empedrado que es de no sé cuando...

No es reciente, fue del 75 más o menos, cuando estuvo el Dr. Toxqui, que tuvo un proyecto de mejora de los centros históricos en San Pedro, Tonantzintla y a todo mundo le puso empedrado no?,

C: Pero parecía que la gente originaria no estaba muy de acuerdo con el empedrado...

No, no estaba muy contenta con el empedrado, no estaba muy contenta con la fuente,

C: ¿La fuente fue también del periodo anterior?

Sí, incluso que la denominaran que es el...tanque, el tanque para que beban agua los animales, o que es tanque donde lavan los rábanos los de San Luis, es que San Luis se dedica a la agricultura y..tienen tanques similares donde lavan así los
rábanos...

C: Y creo que esto le quita mucho espacio a la gente cuando son las fiestas ¿no?

Le quitó espacio pero es otra de las cosas que también atrajo gente que viene a ver la fuente, o sea le dio otra vida también.

\section{C: ¿Y las personas que vendían ahí?}

Fueron trasladadas porque primero les rentaron un local en un mercadito municipal ahora estan en la 5 de mayo tengo entendido... Si y qué bueno que también lo hicieron porque también si no después vamos a tener este centro histórico lleno de ambulantes. Y no regulados, no quieren participar en cierta normatividad de giros comerciales, pues debían tener cierta normatividad como comerciantes ambulantes ¿no?

\section{C: En general este espacio del zócalo qué nuevas actividades tiene?}

Pues ahorita estamos generando actividades artísticas, conciertos...

C: Y ése vecino que está con ese negocio, ¿también organiza tocadas o conciertos...? Pero solamente para su espacio adentro. La mayoría de los que organizan es para su espacio, para generar más comercio,
mayor flujo

\section{C: Hasta ahora ¿cuántos comercios hay en esta área?}

No tendría idea, porque también hay unos que no funcionan cierran, abren otros..y además aquí en toda esta área precisamente como que ha costado más abrir nuevos negocios, comercios. Porque incluso toda esa área de comida que hay en la 14 funciona pero si ponen acá, pues ahí va no? Luego les cuesta, les cuesta.

Eh, ahorita se está pensando posiblemente poner un corredor turístico de la pirámide para acá

\section{C: ¿Por dónde sería?}

Vé que hay una calzadita, acá atrás? Esa calle sería y tiene que llegar acá. Esperemos que se lleve a cabo ese proyecto. 


\section{$C:$ ¿Ese es proyecto municipal?}

Sí, el municipio tiene algunos proyectos también respecto a la zona arqueológica, hay varios proyectos pero dependen de que sean aprobados.....

\section{C: ¿Siguen ustedes participando en la feria?}

Eh este año no se participó

C: Había visto que organizaban hasta carreras de caballos...

De hecho las carreras de caballos si se llevaron a cabo, y las vaquillas que es algo característico ya de San Andrés, cultural no?

\section{C: ¿Cómo les llaman?}

Creo que si le habían llamado Cholulada pero fue en otra administración, ya vé que son celosos en las cuestiones de los nombres y eso,

C: Pues retomando esto de los actores que están involucrados en este desarrollo, en este avance, del municipio, quién más estaría

En el desarrollo...

C: $\mathrm{Si}$, cómo están coordinando pues acciones, o ¿con quién más

Acciones.....pues hay si yo lo veo totalmente desvinculado no? Le digo por eso es que se está teniendo un crecimiento totalmente irregular, por eso es que se están estableciendo ciertas negocios dónde no deben, se están construyendo cosas que tampoco deben, entonces yo creo que los que están ocupando ciertos cargos como...

Si les falta conocer un poco más de todo esto y los que son los regidores si les faltaría también conocer

C: Si pero bueno, la instalación de todas esas cosas o la construcción siempre está regulada por...

Obra pública, entra desarrollo urbano de aquí del municipio...generalmente operan con el reglamento estatal en el que se apoyan, pero yo que sepa de un reglamento municipal no hay, porque tendría que ser publicado en un diario oficial.

C: De alguna manera la posición de las autoridades es a favor de ciertas cosas, pero no de todo lo que está sucediendo...

Pues sí ¿como qué?

C: Pues en esto de establecimientos, construcciones...

Pues es que es otra de las cosas no?, yo creo que al municipio mientras más dinero le entre...(risa)mejor, ése es el problema. Precisamente lo discutíamos con el comité Pro-Cholula, muchas veces uno de los destructores del patrimonio es el municipio, muchas de las autoridades y no nomás municipales, estatales y federales; son los primeros que destruyen el patrimonio, no tanto las comunidades.

C: En esta calle de la 14 oriente, exactamente, ustedes ino se vinculan por ejemplo con la UDLA, con las autoridades de la UDLA para conseguir cierto apoyo?

No y además son demasiado herméticos a veces, a veces son...

C: ¿Se te acercan cuando...suele haber algún interés?

Si eso sí, eso si sería el fin. Nosotros nos hemos tratado de acercar para lo de las becas y todavía no nos han recibido no? También depende de las autoridades de la universidad. Una vez me invitaron unos chicos a dar una plática en la universidad, de las Américas, precisamente porqué esta separación entre San Andrés y la Universidad, si estamos dentro del municipio, cómo es posible que no nos sintamos parte. Es un gran problema de la institución porque no sabe dónde está parada, entonces hace programas pero no en beneficio de la comunidad, de su gente y les vamos a apoyar. Entonces yo creo que primero es conocer dónde estoy parado, quiénes son, cómo funciona y en base a eso ahora si plasmo proyectos que puedan ser útiles a la comunidad..

C: Pues ustedes como comunidad receptora deberían tener ese derecho ¿no? Y ese reconocimiento de su parte porque..

Sí porque cambió la imagen a partir de que abrió la puerta de la 14, y eso fue un gran avance porque también antes eran....y yo también siento que la universidad no es como la BUAP, o sea el compromiso del servicio social hacia la comunidad, eso es muy distinto

C: Yo había visto, en una ocasión que estaban ofreciendo cursos de alfabetización, aquí en este Centro que tienen en la esquina .. 
Ahi pero es que luego también son proyectos aislados, no los hacen de manera coordinada con nosotros, tampoco les van a funcionar no?

C: O sea, es como sin interés, nadamás para justificar quizás su presencia

Yo creo que sí,

C: Porque creo que hay mucho que hacer aquí..

Desde la diversidad podría hacer infinidad de cosas no?, desde rescate del patrimonio, fomentos educativos, igual fomento al turismo a lo que sean cuestiones culturales podría apoyar la universidad..

C: ¿Y tienen algunos convenios de becas con las demás universidades que se encuentran aquí?, como la Madero... La Madero tiene convenios..sí, hay algunas otras que no dan la beca directamente, sino que la gente tiene que ir directamente a solicitar su beca.

\section{C: Ustedes les dan los requisitos...}

Si nadamás somos como un enlace. Adonde si tenemos la firma de un convenio es con la universidad interamericana, no? Pero pues ese convenio equivale a que no pague impuestos y equivale a becas, entonces no hay un balance ahí..entonces ya ésa es con la que más trabajamos.

C: Eh lo que son la convivencia social, llamémosle así, de estos chavos ahí en el espacio, especialmente los fines de semana, no sé, debe derivar...

Es algo aislado

C: En algunos problemas, desorden digamos...

Sí, pero también como que está muy apartado de lo demás. A lo mejor la gente aledaña al sitio..

\section{C: Los vecinos.}

Sí, les afecta, los demás... por ejemplo yo vivo en la 8 oriente

C: ¿Hay policía que aquí el municipio la tiene permanentemente ahí como antes? había una policía montada.. Ah no si tienen su equipo de policía, están patruyando los que tienen los caballos o los que andan caminando porque ya también en la 5 de mayo hay policías caminando

C: Pues entonces ya lo solucionan ahí directamente y ya...digamos los vecinos no vienen a quejarse o pedir apoyo con ustedes,

Pues hasta ahorita no han venido, no sé, a lo menos que, a lo mejor aquí tendría que checar con los de seguridad pública, qué tanta incidencia hay de denuncias no? Porque hay gente que vive ahí cerca de la 14, que yo conozco y sí, o sea, están molestos. Molestos porque dicen es que pasa cada cosa que sí violaciones que sí...entonces a veces mejor ni te metes, mejor cierras tu puerta, o qué haces? O llamas a la patrulla y punto qué más?

C: En cuanto a migración ¿usted no ha visto que este problema esté en aumento?

Hay regiones por ejemplo en el área de San Luis, hay muchos que si se están yendo al otro lado,

C: Pero ¿aquí de la cabecera?

Pues si hay pero no muchos verdad Liz?(secretaria) No no hay muchos

C: Es que básicamente me pienso restringir a la cabecera.. Otra cuestión que supe es de un lugar, un jardín botánico que han puesto aquí, que pienso ir a visitar

Se llama "Rosmarinus"

C: Si está adentro de la cabecera; no?

Sí,

C: ¿Son avecindados verdad?

$\mathrm{Si}$, pero la persona que está a cargo le interesa mucho la cuestión de la historia, las tradiciones,

$C: Y$ ¿más negocios que se hayan venido a establecer?

Pues sobretodo restaurantes, discos, bares

C: ¿Fuera de eso? Algo así diferente?

Más cosas que se hayan venido a establecer por acá...Liz? 


\section{C: ¿Tiene fábrica de muebles verdad?}

Sí, Liz: hay una fábrica de yogurt por acá..

Y bueno también los que procesan de manera tradicional en las casas, la gente que tiene vacas...

C: Todavía hay algo de ganadería..

Sí, muy poca, o compran la leche y ellos la procesan,

C: Este, qué planes o cuáles son sus prioridades aquí en este departamento?, sé que usted ve nadamás educación y cultura..

Exactamente,

\section{C: Pero es la oficina de desarrollo social,}

$\mathrm{Si}$, desarrollo social que abarca otras jefaturas como participación ciudadana, y está desarrollo económico. En lo que es cuestión cultural pues nuestro propósito es promover, difundir, a través de concursos, convocatorias, y todo lo que se pueda, lo que son las tradiciones no? Apoyos institucionales, eventos artísticos, ..tenemos también la propuesta de promover lo que es el apoyo a la investigación, sobretodo por lo del centenario y bicentenario, hay la propuesta también de algunos artículos de publicación, de conciertos, este..., foros, de difusión educativa no? De hacer parte a los jóvenes de la problemática social, tomarlos en cuenta no?, talleres de prevención, drogas, lo que es todo, de sexualidad también, algunos talleres de escuela para padres..

\section{C: Eh, ¿alguna novedad que incluyan ahora?}

Intercambios culturales, con lo de los coros tuvimos siete coros de diferentes nacionalidades, tuvimos la visita de Panamá. A san Andrés le toca participar en Panamá y Ecuador en Mayo no?

\section{C: ¿Y la iglesia puede ser escenario de esto?}

Ah claro; pero es otra de las cosas que no nos hemos concentrado ni a la cabecera, ni a realizarlos en el auditorio, sino que nos hemos ido a esos espacios abiertos donde la gente acude..

\section{C: $\underset{i}{ }$ Y en Tonantzintla?}

$\mathrm{Si}$ hemos llevado al coro de Uruguay, tuvimos un intercambio con Tlaxcala con el carnaval, otros eventos artístico, mimos, ballets folklóricos, etc.

\section{C: ¿Y aquí en el zócalo también?}

Pretendemos también darle vida al zócalo, la reapertura de la casa de la cultura como un espacio de creación artística..donde se den clases de música..

\section{C: ¿Adónde está ubicado ese espacio?}

De hecho no hay, la administración anterior la cerró, pero está administración pretende volver a abrirla por ahora el espacio con el que contamos sería el kiosko y de ahí generar una serie de actividades, para después ya tener un espacio físico, bien no?

\section{C: Ya un lugar destinado..}

Exactamente no?

\section{C: ¿Tienen aquí un auditorio también?}

Si se están llevando a cabo talleres de danza

C: Antes me habían platicado que aquí(en la terraza del municipio) había clase de baile para adultos..

Si había baile de salón, danzas polinesias, folklórica, no había muchos talleres, si. Entonces le digo se pretende trabajar, pero generar desde el zócalo todas esas actividades, incluso darlas al aire libre para que la gente se sienta parte de.. incluso que no hay ese obstáculo de que tengo que ir a un salón

\section{C: ¿Dirigido a gente de la comunidad?}

Eh, se abre al público en general, aparte de la cabecera se tiene también la presencia de las juntas auxiliares, incluso del mismo municipio de San Pedro, que le queda más cerca...

\section{C: Tiene algún programa mensual o algo?}

Si se va trabajando, por ejemplo ahorita tenemos lo de las ofrendas, el concurso de ofrendas pero los tenemos en borradores...

C: Si me dice yo tomo nota para tratar de venir..

Ok, ahorita, los próximos tenemos en el mes de noviembre.. 
El concurso de ofrendas que se va a llamar: Conmemora a tus muertos y

Prácticamente son ofrendas típicas mexicanas no?

C: ¿En qué espacio?

En el auditorio y ya se llevaron las convocatorias a las diferentes escuelas del municipio. A escuelas o asociaciones civiles del municipio,

Después el 11 de noviembre tenemos un concierto de ensambles y saxofones y van a haber también eventos artísticos no?

Estamos pensando también que para el 20 de noviembre que es el centenario de la Revolución mexicana, pues hacer también conferencias, no se si hagamos un ciclo de cine, obviamente ceremonia tiene que haber no?

30 de noviembre tenemos lo que es la fiesta patronal que es el 30 y $1^{\circ}$. De diciembre, ahí es con eventos artísticos,

En diciembre estábamos pensando, todavía tampoco lo tenemos claro, posiblemente hagamos un concurso de coros, para villancicos no?, en todo el municipio, se lanza la convocatoria porque hay coros en todas las comunidades,

C: Ahora, ya aprovechando su amabilidad, ¿qué espacios me sugeriría usted para observar sobretodo estos cambios que están afectando de alguna manera a la comunidad?

Sobretodo en las fiestas tradicionales, sería muy interesante que usted entrevistara a las que son encargadas en las fiestas, por ejemplo a las floreras, a los que son encargados los cuetes, a los castilleros para que ellos le comenten cómo se ve afectado tan solo en sus colectas que gente participa y que gente no. Y se va a encontrar que esa zona participa ya menos(la 14) y del zócalo hacia adentro la gente todavía porque no hay tanta influencia de... Yo lo observé hace algunos años porque me invitaron a ser parte de un comité, y observé muy bien la falta de participación.

C: Pero.. sí sigue funcionando la fiesta tradicional con dos comisiones ¿no?

Pero sería muy importante para ver, conocer las dos versiones no, con los castilleros, saber qué está pasando en una fiesta como la tradicional y que se realiza desde la época colonial, como la gente está respondiendo a estos cambios y generalmente las chicas participan en varios comités de estos y tiene la experiencia del año pasado, el antepasado, y pueden decir cómo ha ido variando.

C: Y eso es en actividades ¿y en cuanto a espacios? Digamos en espacios donde se den más conflictos

Pues la 14, toda la zona de allá,

C: Yo he visto ahora que muchas familias durante esos conciertos que se hacen en el Pulke-para2, que terminan a las tantas de la madrugada, ya tienen una forma de tener ingresos por la venta de...

Comida, trabajan en vallet parking, trabajan en los mismos espacios, o sea si genera también un ingreso económico

C: O sea una forma de tener ingresos..

$\mathrm{Si}$, y tiene una parte positiva y otra negativa, por un lado está afectando y pues es natural, con la conurbación y todo eso va a ir modificándose esos aspectos tradicionales no? Como por otra parte también genera empleo

C: Los jóvenes ¿cómo los ve en ese sentido de las tradiciones, cómo las ven?

Pues la gente todavía participa muchísimo, no? Porque es todo esto de la cuestión de ser parte de un mundo no?, ser parte de este San Andrés, de mi identidad, a lo mejor no lo ven así pero mucha gente se quiere sentir parte de no?, tan interesante, pero a lo mejor no lo hacen de una manera consciente pero participan y les permite tener ciertas cosas de la misma comunidad, pero se participa en el barrio, en las ferias, las tradiciones, no cualquiera no?, porque alguien de fuera, que no sea nativo, dificilmente participan en estas actividades, es lo que le llaman derecho de ser Hijo de Barrio, no?

Y si cooperan o no, formar parte de un barrio, implica participar, cooperar para formar parte de ese mundo ..

C: Digamos que ahora yo considero que es un municipio bastante interconectado con la globalización, hay bastante franquicias que se han estado estableciendo en esa parte de la Recta, ¿eso es todavía San Andrés No?

Mhmm, si una parte sí,

O sea lo que sale de Cuatro Caminos hasta la recta? Adonde está Mc Donalds, y todo este...el Starbuks y Pero es eso hecho para los mismos chavos de la universidad, ahí no va a ver mucha gente de San Andrés, no los va a ver en Mc Donalds, en Starbks.

C: Por ejemplo ahora ya hay un cajero automático aquí abajo.. es un servicio que la comunidad necesita y...la obligan a moverse allá que está destinado a la comodidad de los demás.. Si

C: O sea, aquí ha habido un gran surgimiento de comercios destinados a ese tipo de público ¿no? 
C: Esa es la parte que digamos está creciendo rápidamente y poniéndose al servicio de los demás. Entonces ahí es donde yo diría que ¿de qué manera se están preparando ustedes para eso?

No, como que la población solamente vive así(frota palmas)

\section{C: ¿Y el municipio también?} Es que depende porque cada administración tiene sus programas, tiene sus proyectos, entonces se vienen abajo esos y van
otros

\section{C: Y así es como van dando prioridad a otras cosas ¿verdad?
Sí}

\section{C: ¿Avanza o se detiene..?}

Así es

C: En cuanto a las asociaciones civiles; ya no tiene conocimiento de otras?

No, que yo sepa no, han surgido otras que a favor de apoyo a la comunidad que para grupos de la tercera edad, pero no se como funcionen, cuántos grupos hayan

C: Y si un avecindado aquí tiene alguna queja ¿puede venir aquí con ustedes para....

Ah claro, para eso está la contraloría, municipal,

C: Pero la contraloría ve cuestiones de recursos ¿no?

Si pero hay una contraloría que ve eso de la transparencia, de las llamadas de la

Ciudadanía

C: Entonces ¿ve eso de la participación ciudadana? Aquí tendría que ver eso y no están los encargados, si para que pudieran decirle que programas llevan en apoyo a la
comunidad

C: Se supone que ellos son los más cercanos a la comunidad.. Sí C: Ahí la zona de la pirámide, también es un lugar adonde se están encontrando nuevos actores, yo me fijé que
para el festejo del equinoccio de la primavera,

Si ahí ya hay un problema de cuestiones de ambulantes eh? Pero es más que nada gente de fuera, de Oaxaca y demás y que la población de la comunidad no se ve tanto beneficiada como ellos y es que ahí como hay un problema limítrofe
entonces

C: ¿Que zona considera de las limítrofes, la más conflictiva, con Puebla o con San Pedro?

Con Puebla es algo político más que nada, esta documentado está toda la información pero falta que se lo den a San Andrés, porque hay muchos tanto intereses políticos como económicos. De este lado es más situación de las tradiciones calle es de San Andrés, lo mismo dicen los de San Pedro y son conflictos y son coloniales

C: Se van haciendo negociaciones, suaves,

Muchas veces ni hacen falta cada quien como que sabe. A veces se reúnen para proyectos turísticos que quieren hacer, fomentar el turismo en torno a la pirámide, al santuario, pero la cuestión limítrofe la dejan aparte. Y así también lo ha dejado ver el INAH porque es una propiedad federal, entonces no se peleen porque esto es una propiedad federal.

C: Desde su perspectiva, ¿que tipo de estudios favorecerían a San Andrés?

¿en estudios de que tipo?

\section{C: Investigaciones como esta} A mi me gustaría por ejemplo en una muy buena investigación, las cuestiones de las tradiciones que no han sido
abordadas. Por ejemplo un inventario

Otra cosa la cuestión oral, lo que pasó en la revolución hablar con los ancianitos, eso es muy importante no?

Mi interés también es sacar una convocatoria para todos los proyectos que ya se tengan, porque mucha gente ha escrito sobre San Andrés, poder formar una compilación, eso sería interesante. Que se incluyan cultura, tradiciones, costumbres,
de Sociología, Antropología, Historia no? 


\section{- SEGUNDA PARTE ENTREVISTA A FUNCIONARIA MUNICIPAL}

Fecha: Junio, 2009.

Lugar: San Andrés Cholula

C: Cuando tu me hablaste de "Centro Histórico" comentábamos también de esa imagen urbana que no se respeta, y mencionaste también que hay como un vacío de reglamento... un reglamento municipal, sobre el cual apoyarse y que todo
se manejaba desde el Estado.., quiero aclarar si estoy bien o no

F: Estás en lo correcto, hay propuestas, ya desde... no se si sea decreto eh.. es un reglamento, una propuesta y esperemos que lo revisen no? Porque INAH tengo entendido que ya tiene de hecho esta propuesta de reglamento para la aprobado... para uso de suelo, una reglamentación, de centros históricos, pero no sé si ya esté revisado, no sé si ya esté C: Pero si está redactado, ¿está en trámite?

$\mathrm{F}: \mathrm{Si}$

C: ¿Desde cuando iniciaría el trámite?

F: Mira...la propuesta está desde la administración pasada pero no fue aprobada por Cabildo... esta administración no sé si ya se la entregaron oficialmente, yo se que hay una, pero no se si ya fue entregada de manera oficial por parte del INAH para su revisión, eso tiene que ser, esa formalidad donde una institución lo solicita y la tiene que tratar el Cabildo.

$\mathrm{C}$ : Se trata de un proceso muy largo, me imagino.

F: No hasta eso no si el INAH en este momento decidiera traerlo de manera formal y dijera Sr. Presidente se recibió esta propuesta de reglamento, para uso de suelo para regulación de centros históricos o delimitación...este, aquí esta se sometió a revisión, y ellos en el próximo cabildo lo tratan no?, a lo mejor lo mandan a revisión a desarrollo urbano, hacen
sus debidas acotaciones y pues se llevaría a cabo no?

C: Esto no crees, que ¿si se reglamenta el uso de suelo se afecte algunos intereses?

F: Yo creo que sí afecta adonde no se ha aprobado no? $\mathrm{C}$ : Entonces, si se necesita un reglamento municipal que regule toda esta cuestión de la imagen urbana y el uso de suelo,
pero no hay aprobado nada... se está trabajando

F: No, hay aprobado, no hay, también se está trabajando, se contrató a una empresa para la elaboración de... que se busque toda la documentación necesaria para que se busque la declaratoria de patrimonio pero no nomás de la cabecera, sino del municipio, se está trabajando de manera conjunta con San Pedro Cholula, eh... yo espero que a mas tardar en unos tres meses quede concluida toda esta papelería junto con un libro, viene el catálogo de monumentos, viene el reglamento o sea si no funciona el del INAH, puede funcionar este, porque es un trabajo entre los dos municipios que se
está haciendo una investigación.

C: Pues le decía yo, eso ¿afecta intereses?

F: No creo, porque si no no hubiera aprobado este proyecto, o sea, yo creo que a esta administración no, porque si no no la hubiera aprobado, es un proyecto que además sale bastante carito porque exige investigación, implica una publicación,

C: Y de acuerdo a sus conocimientos ¿cuáles serían los monumentos...

F: Importantes? Tenemos 33 monumentos... Religiosos 33, más aparte Casa de Gobernador..
C: ¿Y en la cabecera?

F: en la cabecera son 9 templos de gran interés

C: Eh... andan entre siglo XVII y XVIII.

F: Tenemos algunos que inician sï, XVII y XVIII van a ser la mayoría, muy pocos van a ser XVI como el caso de la

Parroquia, de ahí en fuera, pues La Casa del Gobernador también va a ser XVII, porque muchos de ellos aunque obtuvieron su autorización en el XVI, pues no es la construcción así como la vemos, sino seguramente empezaron con
chozas de carrizos y adobes es así como empezaron..

C: Pero también me comentabas de unos límites...por ejemplo me decías el Centro Histórico llega hasta la 14..o hasta tal. $\mathrm{F}$ : NO, no no, yo creo que aquí tendrían que valorar y hacer o sea cual es el centro históricos, cual es la división entre
barrios, que en el caso de San Andrés, no la hay,

C: $Y$ ¿un conocimiento local?

F: Si pero no establecido, sabes porqué? Porque en el caso de San Andrés y San Pedro es muy distinto, la cuestión de
división, en San Pedro si va por calles, de tal calle a tal calle es el barrio división, en San Pedro si va por calles, de tal calle a tal calle es el barrio tal..yo tengo el mapa donde se lo comprueba, en población totalmente endogámica, es muy distinto porqué? Porque la comunidad sanandreseña en ese momento era una población totalmente endogámica, totalmente cerrada que no permitía el acceso de otros a ese universo, entonces los españoles se dieron cuenta de eso y para garantizar la movilidad territorial entre los mismos pobladores el intercambio de San Juan viviendo en Santa María hace es establecer gente de un barrio a otro barrio, entonces vas a encontrar a gente apellidos, por familias 
C: Si, pero digamos la gente dice "el centro"... ¿ ¿hasta dónde es?

F: Pues no hay un límite, no, tendría que establecerse y no sé bajo qué criterios lo hagan,

C: ¿En la 12 todavía se llama centro?

F: No porque ya está en las afueras, ya es el barrio de San Juan Aquiáhuac, y es otro rollo no? no.. el centro solamente es esto, no se cuantas calles podrían contemplar como centro histórico, pero ahí depende de los que están haciendo la revisión que seguramente lo va a revisar obras públicas con los arquitectos para determinar cual es el area más adecuada para declararla como patrimonio no? Y una zona de monumentos,

C: Independientemente de eso, la renovación que se ha hecho al centro, la imagen urbana..

F: Todo está autorizado por el INAH eh? Aquí no te permiten una obra si no es realizada, si no es certificada, se tiene que meter la petición al INAH, incluso cuando hay trabajos de excavación y todo eso, te mandan gente para ver si encontraron
una ofrenda, algún enterramiento, todo esto no? $\mathrm{C}$ : Si es lo que iba yo a preguntar, si yo comprara aquí un terreno, donde hubiera restos de alguna casa, bueno, yo tiro
todo, construyo, ¿y?

F: No pero tienes, o sea, aquí el ayuntamiento te puede clausurar, para empezar, la obra,

$\mathrm{C}$ : O sea ¿es requisito avisar al INAH? En todo el área del centro?

F: Sobretodo para algunas personas que ya te digo en este catálogo estarían identificadas, y eso hace falta, porque muchas de las veces no se defiende no está en resguardo este patrimonio porque no hay un catálogo, no hay una descripción de los inmuebles no? Y creo que va a aumentar el total del patrimonio, de inmuebles, porque hay casonas del siglo XIX, que a lo
mejor no estaban contempladas, y hoy si ya aparecen C: Alguien me decía, es que en toda la región de Cholula encuentras restos, cosas....., entonces el INAH qué puede hacer
ante eso...

F: Te detiene la obra..

F: Pues aquí depende de la buena voluntad de la gente, que tu avises porque igual cercas, o sea depende de tu buena voluntad y tu conocimiento de las cosas, dices... bueno esto es propiedad de la nación, no es mi propiedad
entonces...llamas, vas a hacer tu obra de todas maneras. INAH continúas tu obra.

C: Entonces ese es el procedimiento..

F: Si, el procedimiento, y ya en cuestión de las iglesias bueno en San Pedro ya sabemos, que quien maneja muchas de las cosas es el padre Tapia, o sea que cada que entra una Comisión le dice, bueno yo quiero tal cosa, quiero que hagan tal cosa no? Les dice quiero que hagan un salón grande para tal evento,

C: ¿el padre lo solicita?

F:Sí, a cada nuevo fiscal cada año y..

C: ¿lo hace para San Andrés también?

F: No no no, para San Pedro, son jurisdicciones totalmente distintas y operan diferente

$\mathrm{C}:$ ¿Y aquí se hace lo mismo?

F: No, aquí no se pide obra, aquí la comunidad decide qué obra quiere hacer, alguna vez estuvimos trabajando algunos proyectos de CONACULTA para el mantenimiento de los inmuebles y ellos sugerían, bueno como parte del proyecto pudieron haber hecho también un inventario de necesidades para que los fiscales que continuaran dijeran bueno pues ahora si pues le hace falta la impermeabilización, es indispensable esto, que la decoración, pero depende más que nada de
lo que ellos decidan como fiscales, no?

C: ¿Ese es un mundo aparte ¿no?

F: Si si totalmente y ya ves que tiene su origen en la época prehispánica

$\mathrm{C}$ : Y en esta renovación del centro, de la imagen, porque yo vi que durante mucho tiempo no le hicieron nada..

F: si estuvo registrada ante el INAH, se hizo evidentemente acá se hizo un estudio,se presentó ante el INAH y ya se
pintaron..

$\mathrm{C}: \mathrm{Y}$ ¿qué intereses les movieron a realizar esa obra?

F: Ahí si no sabría, tendríamos que platicar con el de obras públicas o si fue un proyecto nomás de la administración, o de

la imagen urbana, una propuesta de imagen urbana.

C: De algún tiempo para acá me imagino que se han interesado en proyectos de tipo turístico entonces...

F: Aquí hay varios proyectos, si quieres ahorita te comunico con la chica de turismo, hay un proyecto

C: Hasta ahorita ¿qué obras nuevas se han realizado en la zona de la pirámide? F: Solamente el.. complejo deportivo que es una cancha de tartán, este con varios juegos, que por cierto ha tenido una
aceptación bastante bastante alta...

C: ¿La van a cercar? F: Está cercada ya .. bueno le faltan algunos detalles... de hecho ya lo inauguraron, me estaban comentando el otro día
que la visita como 250 personas diario...

C: ¿son personas de aquí?

F: San Andrés, San Pedro, Cuautlancingo, o sea viene mucha gente...

C: ¿Avecindados?

F: Sí muchísimos, yo creo que son los que más practican el deporte no?

C: Si, ya tienen esa costumbre

C: Bueno ya para terminar, en este posible reglamento del centro histórico... 
F: De centros, ahí ya serían centros, juntas auxiliares, y cabeceras no?

C: O sea, ¿se está haciendo este trámite en conjunto?

F: Si, o sea hay una empresa que se está dedicando a hacer la investigación nadamás de la cabecera,
C: ¿Y San Pedro? F: También, o sea esta empresa está trabajando los dos municipios, se toman como municipios, no nadamás como
cabeceras, lo que era la región cholulteca

C: Es muy grande

F: Si, faltaría Santa Isabel, Coronango, para que incluyera toda la región de Cholula no?, porque eso sería muy importante

C: Pues está muy interesante..y ¿en que tiempo me dices que.

F: No sé yo calculo que dos o tres meses, espero que ya, porque ya están en revisión varias cosas, me pasen el catálogo, lo chequemos, vayamos a verificar todo esto, para que ya la publicación esté lista

C: Bien, ¿qué efectos beneficiosos crees que traería a la población de aprobarse?

F: uy, pues muchísimos, para empezar ya tendremos el inventario del patrimonio, la defensa del patrimonio ya no puedes destruir porque está catalogado, ya no puedes ... lograr tan solo tener el expediente ya es mucho no?, porque ha habido muchos intentos pero jamás se ha logrado, ha habido muchas asociaciones civiles que han querido formar el expediente patrimonio no?, pero bueno, a lo mejor podemo era muy difícil porque también ya ha sido muy manoseado el C: Pero tal vez ese deterioro tenga que podemos detenerlo, ya con detenerlo......seguir con el deterioro sería muchísimo crítica a estos proyectos patrimoniales tan interesa resolución de la vida cotidiana de las familias y... ahí es donde hay una gente.

F: No, porque tendría que sensibilizarse a la gente a que.. C: Eso justamente los lleva a realizar cambios culturales y eso pues como que ¿altera la vida social de los pueblos, no?
Cuando ya se patrimonializa el lugar..

F: Yo no lo veo tanto así eh?, yo lo vería como más en beneficio, porque de todas maneras la cultura tiende a cambiar, y va incorporando siempre elementos en la socialización, las formas tradicionales en las comunidades, siempre va cambiando. Pero si con esto logramos, también con el proceso de urbanización en San Andrés, en San Pedro, entonces si va Cholula puede ser, una de sus actividades económiterior de ese patrimonio, que además en un futuro se supone que lo reglamentamos después ¿que ofreces?

C: Sería como también llevar a la población a un cambio de actividades actuales para después integrarse al turismo F: Si porque ya, anteriormente San Andrés estaba dedicado a lo que era la agricultura y la ganadería y hoy que hay? Entonces son...no sé.... porque ve que ha venido cambiando su vida cotidiana, entonces quieran o no son procesos... Entonces uno más? ... digo.....Y además con beneficios? ... yo lo veo como un beneficio que se evite deteriorar....Porque no le va a permitir respirar al muro y le va a traer humedad mármol, si eso le va a traer un daño, le va a traer un daño porque suprimiendo. 
